UNIVERSIDADE DE SÃO PAULO

FACULDADE DE FILOSOFIA, LETRAS E CIÊNCIAS HUMANAS DEPARTAMENTO DE GEOGRAFIA

PROGRAMA DE PÓS-GRADUAÇÃO EM GEOGRAFIA HUMANA

\title{
ÁGUA E SANEAMENTO BÁSICO: A ATUAÇÃO DO GRUPO SUEZ EM LIMEIRA E MANAUS
}

Cristiane Fernandes de Oliveira

São Paulo

2007 
UNIVERSIDADE DE SÃO PAULO

FACULDADE DE FILOSOFIA, LETRAS E CIÊNCIAS HUMANAS

DEPARTAMENTO DE GEOGRAFIA

PROGRAMA DE PÓS-GRADUAÇÃO EM GEOGRAFIA HUMANA

\section{ÁGUA E SANEAMENTO BÁSICO: A ATUAÇÃO DO GRUPO SUEZ EM LIMEIRA E MANAUS}

Cristiane Fernandes de Oliveira

Tese apresentada ao Programa de PósGraduação em Geografia Humana, do Departamento de Geografia da Faculdade de Filosofia, Letras e Ciências Humanas da Universidade de São Paulo, para obtenção do título de Doutor em Geografia Humana.

Orientador: Profa.Dra. Sandra Lencioni

São Paulo

2007 
Aos meus pais, à Flora e ao Cláudio, pelo apoio e carinho que me fortalecem e estimulam. 


\section{AGRADECIMENTOS}

A construção do conhecimento não ocorre de forma isolada e não poderia ser diferente na constituição deste trabalho, por isto, apesar de me responsabilizar pela elaboração desta tese, agradeço àqueles que, de algum modo, auxiliaram em sua concretização.

De forma especial à minha orientadora Profa. Sandra Lencioni, pelo exemplo de dedicação ao ensino e à pesquisa, pelo seu ilibado caráter como educadora e como pessoa, por seu marcado espírito construtivo, pelo constante estímulo e também pela sua sincera amizade.

À FAPESP (Fundação de Amparo a Pesquisa do Estado de São Paulo) pelo financiamento e avaliação crítica da pesquisa.

Às professoras Cleide Rodrigues e Mônica Arroyo pela importante contribuição durante o exame de qualificação.

À profa. Dra. Claudia Monteiro Peixoto, do Departamento de Estatística da Faculdade de Matemática da USP pela orientação quanto à constituição do modelo estatístico a ser adotado para obtenção das amostras da pesquisa.

À equipe técnica do setor de Bromatologia do LACEN de Manaus por ter realizado as análises laboratoriais e por ter me recebido tão gentilmente em suas instalações e à Secretaria Estadual de Vigilância Sanitária de Manaus por ter contribuído com informações sobre a pesquisa.

Ao Instituto Adolfo Lutz e à Secretaria Municipal da Saúde de Limeira por ter propiciado acesso ao Programa Pró-Água.

À empresa AMCOR PET PACKAGING por ter fornecido gratuitamente embalagens para coleta de água envolvida na pesquisa e à Empresa Brasileira de Radiações - Embrarad, pela esterilização dos frascos de coleta de água.

À Marie Odile Monier Chelini pelo auxílio com a tradução do resumo.

Aos colegas de pós-graduação e colóquios, Adriana, Álvaro, André, Cíntia, Claudio, “Cleris”, Márcio, Regina e Terezinha, pelos momentos de discussões e pelo compartilhamento de dúvidas e experiências. 
Aos professores e funcionários do Departamento de Geografia e Pós-Graduação da FFLCH/USP pelo apoio.

Aos amigos pela paciência, compreensão e incentivo.

E por último, porém, não menos importante, à minha família, por ter estado constantemente ao meu lado, compartilhando o trilhar deste percurso sempre com um gesto de carinho. 


\section{RESUMO}

Este trabalho apresenta a análise das concessões dos serviços de saneamento básico, obtidas pelo grupo transnacional Suez S.A., em Limeira-SP e Manaus-AM e procura desvendar em que medida essas concessões integram as novas estratégias de negócios deste mesmo grupo. Nesta análise, procura-se discutir como a obtenção da concessão de importantes áreas com abundância de água pelo grupo Suez, aliada à crescente participação desse grupo no mercado acionário, tem contribuído para a expansão do grupo, embora, no âmbito local, os serviços de saneamento básico nesses municípios apresentem a retração de investimentos.

Deste modo, a discussão sobre os serviços de saneamento básico em Manaus e em Limeira reconhece que a prioridade não é a defesa dos interesses públicos, sendo que houve atrasos e retração nos investimentos, bem como a manutenção do alijamento de parcelas mais pobres da população ao acesso à água tratada e ao esgotamento sanitário, mas sim a defesa dos interesses do grupo por parte das suas concessionárias. A defesa dos interesses do grupo por parte das suas concessionárias, que é o de obtenção de lucros e rendimentos, tem contribuído para a manutenção da condição de exclusão aos serviços de saneamento básico e concorrido para o comprometimento do meio ambiente e da saúde pública, onerando e fragilizando ainda mais o Estado, já que é este quem acaba por assumir as conseqüências destes déficits.

Palavras chave: Estado, água, serviços de saneamento básico, privatização, recursos hídricos. 


\begin{abstract}
The concessions of water supply and sanitation services, obtained by the transnational SUEZ group in Limeira-SP and Manaus-AM are discussed, focusing them as new strategies to spread up the group's businesses. On this analyses, the acquisition of new concessions in water abundant areas in connection with the growing participation of the Suez group in the stock market is emphasized as a business spreading strategy despite of less investments and lack of local water and sanitation services improvement.

In this manner, the discussion about the water and sanitation services in Manaus and Limeira recognizes that the priority is not the public interest, particularly because of the delay on the sanitation investments and the absence of positive strategies in order to include the poor part of the population in accessing drinking water and sanitation but, contrarily, the private interests of the concessionaries and consequently of the transnational group are the main goal.

The defense of the group interests and rentability by its concessionaries has contributed to the maintenance of the water and sanitation exclusion of the less favored social classes and concurred for the environment and public health impairment, so costing and weakening even more the State which is, on the last instance, the one assuming all of those deficits.
\end{abstract}

Key-words: State, water, water supply and sanitation services, privatization, water resources. 


\section{RESUME}

Ce travail présente une analyse des contrats de travaux d'assainissement attribués au groupe transnational Suez S.A., de Limeira-SP e Manaus-AM, et se propose d'évaluer dans quelle mesure ces contrats s'intègrent dans la nouvelle stratégie commerciale de ce groupe. Cette analyse examine comment l'obtention par le groupe Suez de contrats dans des zones importantes dotées d'eau en abondance, alliée á la participation croissante de ce groupe au marché financier, a contribué à l'expansion du groupe, tandis que, sur le plan local, les services d'assainissement de base de ces communes subissaient les conséquences d'une rétraction des investissements.

Ainsi, l'étude des services d'assainissement à Manaus et Limeira montre que la priorité n'est pas la défense des intérêts publics puisqu'on a assisté à des retards et un retrait des investissements ainsi que le maintien de l'impossibilité des couches les plus démunies de la population d'accéder au traitement et à l'évacuation des eaux, et si la défense des intérêt du groupe par ses concessionnaires. Cette défense des intérêts du groupe par les concessionnaires, qui vise l'obtention de bénéfices et dividendes, contribue au maintien de la condition d'exclusion des services d'assainissement et concourt à la détérioration de l'environnement et de la santé publique, portant préjudice et fragilisant davantage encore l'Etat, sur lequel finit par rejaillir la responsabilité d'assumer les conséquences de cette situation.

Mots clés : Etat, eau, services d'assainissement, privatisation, ressources hydriques. 


\section{SUMÁRIO}

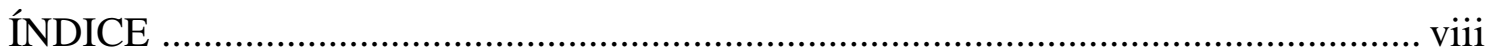

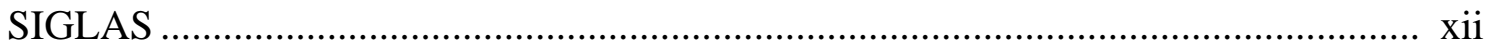

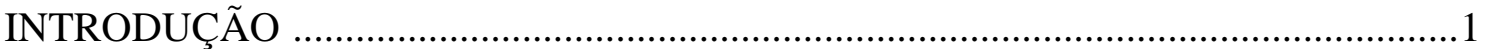

CAPÍTULO I - A valoração e o consumo da água …………………………………....21

1. A disponibilidade de água .................................................................................23

2. A escassez como estratégia de acumulação............................................................33

3. As formas de valoração da água ....................................................................62

3.1. Educação e valoração da água ............................................................................67

CAPÍTULO II - A água como estratégia de reprodução ampliada do capital .................76

1. Privatização do setor de saneamento básico ....................................................78

1.1. A experiência estrangeira ...................................................................................

1.2. A experiência brasileira - O caso do grupo Suez S.A ………………………....90

2. O mercado financeiro e o setor de saneamento básico ........................................109

2.1. Crescimento e estagnação: As duas faces da atuação do grupo Suez S.A. no setor de saneamento básico no Brasil

CAPÍTULO III - A atuação do grupo Suez no saneamento básico no Brasil:

Os casos de Manaus e Limeira

1. A articulação público-privado e as políticas públicas de

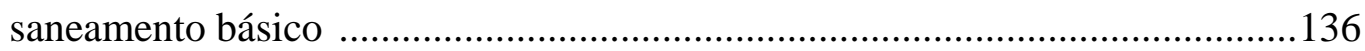

1.1. As políticas de saneamento básico em Manaus ..................................................138

1.2. As políticas de saneamento básico em Limeira .................................................152

2. Os serviços de saneamento básico em Manaus e Limeira:

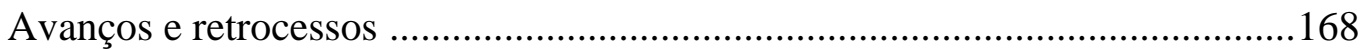

2.1. A coleta e o tratamento de esgotos .................................................................171

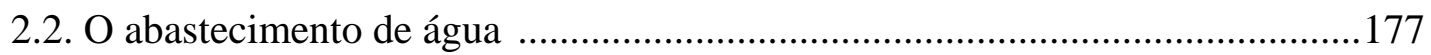

CONSIDERAÇÕES FINAIS ……………………………………………......194

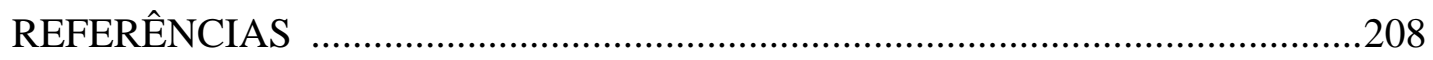

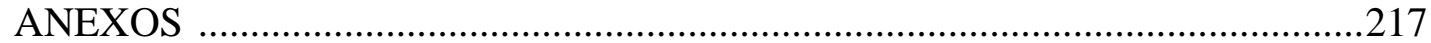




\section{INDICES}

\section{GRÁFICOS}

1. Manaus - Índice de produtividade em função da quantidade de empregados em saneamento básico entre 1995 e 2004 ..............................................................34

2. Manaus. Investimentos em água e esgotos entre 1995 e 2004 ................................37

3. Consumo mundial de água pela indústria $\left(\mathrm{km}^{3}\right)$...................................................42

4. Produção e consumo de água em países com destacado consumo para fim industrial - 2000 .44

5. Produção de água em 2000 e projeção para 2050 em países com grande destaque no consumo de água para fim industrial

6. Países com destacado consumo de água para fim industrial. Participação do consumo de água para fim industrial frente as demandas agrícolas e domésticas .46

7. Brasil - Evolução da Cobertura de Abastecimento de Água .92

8. Suez S.A. Evolução dos dividendos por ações do grupo entre 1997-2005

9 Limeira. Evolução das tarifas médias aplicadas sobre o abastecimento de água e coleta de esgoto entre 1996 e 2004

10. Evolução das tarifas aplicadas pela Cosama, Águas do Amazonas, Sabesp e Cosampa entre 1996 e 2004

11. Evolução das tarifas médias praticadas por empresas regionais entre 2002 e 2004

12. Limeira. Evolução das despesas totais, despesas de exploração, despesas com dívidas e receitas entre 2002 e 2004 (R\$)

13. Manaus. Evolução das despesas totais, despesas de exploração, despesas com dívidas e receitas entre 2002 e 2004. (R\$)

14. Águas do Amazonas - Manaus. Relação entre investimentos e dívidas da empresa entre 2002 e 2004 126

15. Manaus. Evolução demográfica entre 1960-2002 139

16. Manaus. Evolução do Índice de coleta e de tratamento de esgotos entre 1995 e 2004 
17. Manaus. Evolução da extensão da rede de coleta de esgotos entre 1995 e 2006 ...173

18. Limeira. Evolução do índice de coleta e tratamento de esgotos entre 1996 e 2004

19. Manaus. Volumes de água tratados em estações de tratamento de água (p/1000m3/ano)

20. Manaus. Evolução da extensão da rede de abastecimento de água entre 1996 e $2004(\mathrm{Km})$

21. Manaus. Evolução da cobertura de água entre 1996 e 2004 (\%)

22. Limeira. Evolução da extensão da rede de abastecimento de água entre 1996 e $2004(\mathrm{~km})$

23. Limeira. Evolução dos volumes de água aduzidos e tratados em ETA entre 1996 e 2004

24. Evolução do consumo de água per capta em Manaus, Limeira em municípios atendidos pela Sabesp entre 1995 e 2004 186

\section{TABELAS}

1 - Saldo entre receitas e despesas para categorias de prestação de serviços de saneamento básico em municípios brasileiros em 2004

2. Brasil. Porcentagem do consumo de água por setores para os períodos de 1993-1997 e 1998-2002

3. Limeira. Investimentos totais efetuados e contratados em abastecimento de água, coleta e tratamento de esgotos entre 1996 e 2004

4. Limeira e municípios de seu entorno. Despesas totais, despesas de exploração, receitas e despesas com dívidas em 2002

5. Balanços Patrimoniais da empresa Águas de Limeira. Evolução do passivo circulante e despesas e receitas financeiras entre 2002 e 2004

6. Empresa Águas do Amazonas. Evolução das demonstrações financeiras entre 2002 e 2004

7. Limeira. Classe de rendimentos em 1998

8. Manaus - Bairros agrupados por faixa de proximidade da área de captação e cobertura de abastecimento de água

9. Manaus - Quantidade de questionários aplicados por faixa de bairros 165 
10. Manaus - Amostras coletadas por bairro 166

11. Limeira e Manaus - Índices de cobertura de saneamento básico em 2000 (\%) .....168

12. Regiões do Brasil - Evolução da água distribuída sem tratamento (\%) 168

13. Limeira. Evolução da extensão da rede de coleta de esgoto entre 1996 e 2004 .....176

14. Índice de perda de água na rede em municípios do Estado de São Paulo no entorno de Limeira (2004) 186

\section{QUADRO}

1. Regiões brasileiras de maiores ocorrências de saldo negativo entre receitas e despesas em saneamento básico por categoria de prestação de serviços 53

\section{MAPAS}

1: Ocorrência de água mundial e concessões do grupo Suez S.A 63

2. Limeira na área de recarga do Aqüífero Guarani .96

3. Manaus. Índice de distribuição de água e coleta de esgoto segundo a localização dos bairros (2000)

4. Manaus. Cobertura de Abastecimento de água por bairros em 2000 142

5.Manaus. Ocupação urbana em 2000 144

6. Evolução urbana no bairro do Tarumã em Manaus 148

7. Limeira. Ocupação urbana e bairros 153

8. Limeira. Pontos de aplicação dos questionários 158

9. Manaus. Faixas de cobertura de abastecimento de água 161

10. Manaus. Amostras de água não potáveis segundo bairros 180

\section{FIGURAS}

1. Organograma Suez S.A

\section{IMAGENS}

1. Manaus às margens do rio Negro .97

2. Manaus. Ocupação recente na Zona Leste 


\section{FOTOS}

1. Manaus: Bairro Novo Israel - Ausência de caixas d’água ......................................150

2. Manaus. Bairro Cidade Nova - Ligação de água clandestina .................................177

3. Manaus. Bairro Betânia - Abastecimento alternativo ...............................................188

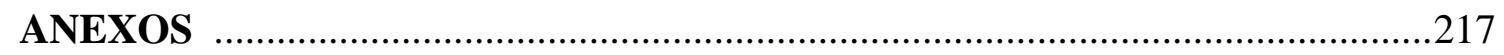

Anexo I - Questionários aplicados em Manaus e Limeira para domicílios abastecidos por água de rede .............................................................218

Anexo II - Questionários aplicados em Manaus para domicílios não ligados à rede de água .....................................................................221

Anexo III - Laudos emitidos pelo Lacen de Manaus..................................................224

Anexo IV - Laudo emitido pelo Instituto Adolfo Lutz sobre amostra de água do Programa "Pró-Água” de Limeira..................................................230 


\section{SIGLAS}

\begin{tabular}{|c|c|}
\hline ABCON & $\begin{array}{l}\text { - Associação Brasileira das Concessionárias Privadas de Serviços } \\
\text { Públicos de Água e Esgotos }\end{array}$ \\
\hline ANA & - Agência Nacional de Águas \\
\hline ASSEMAE & - Associação de Serviços Municipais de Água e Esgotos \\
\hline ARSAM & $\begin{array}{l}\text { - Agência Reguladora dos Serviços Públicos Concedidos do Estado do } \\
\text { Amazonas. }\end{array}$ \\
\hline AySa & - Águas e Saneamento Argentinos \\
\hline BNDES & - Banco Nacional de Desenvolvimento Econômico e Social \\
\hline $\mathrm{BNH}$ & - Banco Nacional de Habitação \\
\hline CAERD & - Companhia de Águas e Esgoto de Rondônia \\
\hline Cosama & - Companhia de Saneamento Básico da Amazônia \\
\hline CORSAN & - Companhia Riograndense de Saneamento \\
\hline CPRM & - Companhia de Pesquisas de Recursos Minerais \\
\hline DAEE & - Departamento de Águas e Energia Elétrica \\
\hline Datasus & - Banco de Dados do Sistema Único de Saúde \\
\hline FAO & - Organização para Alimentação e Agricultura \\
\hline FGTS & - Fundo de Garantia por Tempo de Serviço \\
\hline FMI & - Fundo Monetário Internacional \\
\hline FNSA & - Frente Nacional de Saneamento Ambiental \\
\hline IBGE & - Instituto Brasileiro de Geografia e Estatística \\
\hline ICIJ & - Consórcio Internacional de Investigação Jornalística - \\
\hline NRA & - National Rivers Authority \\
\hline OCDE & - Organização para a Cooperação Econômica e Desenvolvimento - \\
\hline OFWAT & - Office of Water Services \\
\hline OMS & - Organização Mundial da Saúde \\
\hline ONU & - Organizações das Nações Unidas \\
\hline OCDE & - Organização para Cooperação e Desenvolvimento Econômico \\
\hline OSN & - Obras Sanitárias de la Nation \\
\hline PHI & - Programa Hidrológico Internacional \\
\hline PLANASA & - Plano Nacional de Saneamento Básico \\
\hline PMSS & - Programa de Modernização do Setor de Saneamento \\
\hline RMSP & - Região Metropolitana de São Paulo \\
\hline
\end{tabular}




$\begin{array}{ll}\text { RWA } & \text { - Regional Water Authorities } \\ \text { SAAE } & \text { - Serviço Autônomo de Água e Esgoto } \\ \text { Sabesp } & \text { - Companhia de Saneamento Básico do Estado de São Paulo } \\ \text { SFH } & \text { - Sistema Financeiro da Habitação } \\ \text { SFS } & \text { - Sistema Financeiro de Saneamento } \\ \text { SNIS } & \text { - Sistema Nacional de Informações sobre Saneamento } \\ \text { UNCTAD } & \text { - Conferência das Nações Unidas para o Comércio e Desenvolvimento } \\ \text { UNESCO } & \text { - Organização das Nações Unidas para a Educação, Ciência e Cultura } \\ \text { Unicef } & \text { - Fundo das Nações Unidas para a Infância } \\ \text { WSC } & \text { - Water Services Companies }\end{array}$


INTRODUÇÃO 
Tratar a temática que envolve a água não é tarefa simples, apesar de ser possível contar com inúmeras referências produzidas nas últimas duas décadas. Os sub-temas relacionados à água articulam diversas áreas do conhecimento, envolvendo questões pertinentes ao meio físico, biótico e ao meio antrópico, o que certamente exige constante exercício de análise devido à intensa e dinâmica interação entre estes meios. Ainda, ao se considerar a interferência humana, deve ser considerada a necessidade de análise aprofundada das relações econômicas, políticas e sociais que envolvem as estratégias de uso da água.

Grande parte dos estudos aborda a preocupação com o aumento das demandas por água e a deterioração da qualidade das águas com a poluição de mananciais, evidenciando um processo evolutivo em direção à escassez.

Contudo, não é somente preocupante a questão da escassez anunciada ou o crescimento das demandas por este líquido insubstituível, mas também a forma como a água vem sendo valorada, implicando em conseqüências diretas em sua gestão e, por conseguinte em seu acesso.

Entre os desdobramentos do tema “água”, a questão do acesso é de grande importância e envolve uma intrincada rede de interesses e de poder, a qual suscita por sua vez, novos questionamentos concernentes ao envolvimento da sociedade na gestão da água, à saúde pública, à estratégia econômica e à soberania do território nacional.

O acesso à água de boa qualidade e com distribuição ininterrupta é fator estratégico de desenvolvimento econômico e social e deve ser priorizado pelas políticas públicas.

O que se verifica, no entanto, é que as políticas públicas do setor de saneamento básico nem sempre têm alcançado seu objetivo prioritário que é o de universalização do acesso, da elevação da qualidade e também da modicidade das tarifas e taxas aplicadas. Isto se deve em parte à dificuldade de financiamento dos investimentos necessários que o setor requer e que está relacionado diretamente a um processo de adesão às políticas neoliberais que compreendem a transferência dos serviços de saneamento básico à iniciativa privada. 
Esta transferência segundo relatório da própria Conferência das Nações Unidas para o Comércio e o Desenvolvimento - UNCTAD ${ }^{1}$, deveria ser criteriosa, à medida que nem sempre a opção da intervenção privada é a melhor para o desenvolvimento do setor de saneamento básico. A decisão de transferência dos serviços à iniciativa privada segundo este relatório, deveria considerar a renda das populações envolvidas, os custos de investimentos necessários e o possível retorno destes investimentos por parte dos investidores. Quando não são considerados estes aspectos, há riscos de conflitos em razão do repasse dos altos custos de investimentos às populações mais empobrecidas, diminuição das margens de lucros esperadas por parte dos investidores ou mesmo diminuição dos próprios investimentos.

Mesmo assim, este mesmo relatório chama a atenção para o crescimento dos investimentos por parte de grupos transnacionais nos setores relacionados à água, como nos serviços de saneamento básico e energia elétrica, especialmente em países em desenvolvimento.

É importante notar que, apesar de serem notáveis os índices de crescimento dos investimentos dos setores diretamente relacionados à água, estes investimentos ainda representam menos de $10 \%$ do investimento externo direto. Mas, isto não significa que os investimentos no setor de saneamento básico sejam menos importantes, já que a água é essencial para o desenvolvimento econômico e dentro dele a atividade industrial é importante. Por sua vez, as pressões para o aumento dos investimentos também advém do setor industrial.

Nota-se que a diversificação de investimentos por parte de investidores industriais e a busca de domínio sobre os fatores que integram as diversas fases de produção devem ser considerados no que concerne ao apoio dos investidores industriais ao processo de transferência à iniciativa privada dos serviços de saneamento básico.

Deste modo, é importante aos grandes grupos econômicos o controle sobre as questões concernentes ao acesso ao saneamento básico, já que a água é fundamental na produção, mas também, conta a possibilidade de integração vertical entre as empresas internalizadas, como observado por Chesnais (1996, p.84).

Segundo o autor as empresas internalizadas pelo grupo, sob a forma de fusão ou aquisição, significam o fortalecimento da rede com novos fornecedores, produtores e

1 UNCTAD - World Investment Report 2004: The shift toward Services. Disponível em: < www.unctad.org/en/docs/wir2004ch3_en.pdf > Acesso em agosto/2005. 
prestadores de serviços, como o caso dos serviços de saneamento básico. A negociação entre estas empresas, sejam elas de âmbito local ou internacional é estreita e elimina ou restringe a participação de empresas de fora do grupo em seu processo produtivo.

Deste modo, é importante compreender que os interesses que movem o processo de transferência dos serviços de saneamento básico à iniciativa privada e os atores participantes deste processo devem ser desvendados de modo a proporcionar ferramentas adequadas à avaliação desta opção por parte dos gestores na implementação de políticas públicas para o setor.

Para que se possa compreender como tem ocorrido o processo de transferência dos serviços de saneamento básico à iniciativa privada é necessário, em primeiro lugar, esclarecer quais as formas comumente assumidas por este processo.

Segundo o relatório da UNCTAD os modos mais comuns de entrada do setor privado nos serviços de saneamento básico são por meio dos contratos das concessões. Os contratos são mais restritivos e representaram $0,5 \%$ do valor total privado investido no período de 1987 a 2002 em países em desenvolvimento. Os contratos estão relacionados especialmente às atividades de curta duração, que não envolvem investimento de capital próprio e se referem, em geral, aos serviços terceirizados, como de empreitadas para construção ou manutenção de obras de infra-estrutura. Por outro lado, as concessões contabilizaram 64\% e, por meio delas as empresas privadas tem obtido o direito de reabilitar, construir e operar os sistemas de saneamento por um grande período estipulado, normalmente entre 20 e 30 anos. Ainda, segundo o mesmo relatório também são formas de entradas da iniciativa privada no setor os contratos de construção de instalações dos sistemas de saneamento básico, chamados de “Greenfield” e as privatizações propriamente ditas, na qual há alienação total dos ativos.

Nos países em desenvolvimento e, por conseguinte no Brasil a forma mais adotada foi a da concessão.

Do ponto de vista do poder concedente, no Brasil é possível a transferência da responsabilidade pelos serviços à iniciativa privada por parte de instâncias Municipais que é quem detém a titularidade dos serviços.

Para que se possa compreender melhor as competências no que concerne a gestão da água no Brasil, é necessário esclarecer de antemão que as instâncias responsáveis pela gestão dos recursos hídricos não são necessariamente as mesmas responsáveis pela gestão dos serviços de saneamento básico. 
Com base na Constituição Federal de 1988, é possível afirmar que a competência de legislar sobre a água ainda é da União, principalmente ao que tange a questão energética. Os Estados e municípios podem concorrer à legislação da água no que concerne ao detalhamento das diretrizes gerais propostas pela União e, como lembra Granziera (2001, p.72), estas instâncias possuem como atribuições o zelo pela saúde, a proteção do meio ambiente, o combate à poluição, a promoção da melhoria nas condições do saneamento básico e a fiscalização e controle de concessões de uso de recursos hídricos.

Granziera (2001, p.74) ainda observa que a competência administrativa de concessão de outorga de uso da água pode ser da União, dos Estados ou do Distrito Federal e que, apesar da gestão das águas não ser competência dos municípios, eles podem atuar diretamente ou sob a forma de concessão na prestação de serviços de saneamento básico. Nota-se que neste caso, quando o Município optar pela concessão dos serviços à iniciativa privada, esta concessão deve ser acompanhada de outorga do direito de uso da água, emitida pelo órgão competente (Estadual ou União).

Apesar do controle sobre o acesso à água historicamente representar poder e não raramente provocar conflitos, a água por si só, até recentemente, não era valorizada economicamente, mas sim os serviços relacionados a ela. Ou seja, eram compensados financeiramente os serviços de captação, tratamento e distribuição de água, a coleta e o tratamento de esgotos e a geração de energia (hidroelétrica).

Atualmente esta situação mudou com o desenvolvimento de uma nova forma de valoração da água, na qual ela passa a ser valorizada em si mesma.

É importante notar que a valoração da água, ou seja, o ato de se dar valor à ela, tem sido imprimido basicamente de dois modos distintos. No primeiro o juízo de valor está alicerçado na educação e no desenvolvimento da consciência quanto aos impactos das ações humanas no meio ambiente, buscando-se uma alternativa mais equilibrada de uso da água. O outro está alicerçado na economia, buscando-se a valorização econômica da água pela imposição de um preço, que em tese procuraria conter as demandas excessivas.

É importante lembrar que foi a corrente teórica neoliberal que consagrou a valoração econômica da água instituindo não somente a idéia de cobrança pelo uso da água em si, mas principalmente a idéia de que o Estado deveria ser desonerado da incumbência de gestão dos serviços relacionados a ela. 
Portanto, a concepção de valoração econômica da água está associada não somente a tentativa de viabilização dos investimentos necessários à garantia da qualidade e da quantidade de água e ao seu acesso às populações, mas também à viabilização da ampliação e expansão do capital privado internacional, por meio da criação das condições para a formação do mercado da água.

A idéia de valoração da água, portanto, advém do entendimento do uso da água como bem comum ou com base no uso da água como recurso econômico, como procuraremos discutir no primeiro capítulo deste trabalho.

Em razão da importância e da essencialidade do elemento água para a sociedade, como afirma Granziera (2001, p.90) tem havido uma tendência a tornar as águas públicas, buscando na tutela do Estado a garantia de seu acesso. A autora ainda lembra que, para o caso brasileiro, as águas foram afirmadas como bens de domínio público a partir do artigo $1^{\circ}$, inciso I, da Lei n.9433/97.

Segundo a autora, os bens de uso comum, tal como é classificada a água, estariam inseridos na categoria de bens públicos e, apesar da forte característica de liberdade de acesso e de universalidade, como mostra Di Pietro (1989), também o uso do bem comum está sujeito a normas e à regulação com objetivo de conservação da coisa pública e proteção do usuário.

O artigo 225 da Constituição Federal assume a idéia da água como bem comum. Neste artigo se afirma que:

Todos têm direito ao meio ambiente ecologicamente equilibrado, bem de uso comum do povo e essencial à sadia qualidade de vida, impondo-se ao Poder Público e à coletividade o dever de defendê-lo e preservá-lo para as presentes e futuras gerações ${ }^{2}$.

Segundo o Código Civil a água foi designada, “como bem comum” por sua capacidade de garantir a qualidade de vida, do ponto de vista sanitário, a todos os cidadãos. Deste modo, pode-se dizer que a exclusão de grandes parcelas da sociedade para o atendimento de interesses puramente econômicos pode ser considerada desacato à Constituição Federal.

Deve ser lembrado, ainda, que a exclusão do acesso aos serviços de saneamento básico potencializa fortemente o risco de disseminação de doenças veiculadas por água

\footnotetext{
${ }^{2}$ BRASIL. Constituição da República Federativa do Brasil. Capítulo VI, Artigo 225. 1988.
} 
contaminada, o que pode comprometer a saúde pública extensivamente. Sendo assim, a possibilidade de cobrança por serviços de saneamento básico por meio de tarifas ou taxas, devem proporcionar prioritariamente o atendimento das demandas por água e esgoto e a garantia de sua qualidade.

Nota-se que a corrente pró-valorização econômica da água se fortalece com a idéia de escassez da água e adoção da cobrança por seu consumo. Em teoria, a cobrança pela água em si, teria a intenção de controlar a demanda pelo preço e, assim, minimizar a escassez anunciada. Este fato, apesar de não beneficiar as empresas privadas de forma direta, já que compete ao Estado à cobrança pelo uso da água, corrobora a valorização da água como um recurso, fortalecendo o mercado e estimulando a expansão de grandes grupos privados internacionais no setor de saneamento básico.

Conceitualmente, os serviços de saneamento básico estão contidos na definição mais ampla de saneamento ambiental. Segundo resgate teórico efetuado por Peixoto (1998, p.131-132) o saneamento ambiental poderia ser associado ao desenvolvimento de medidas que buscam um ambiente equilibrado, propiciando a prevenção de doenças e a promoção da saúde.

Os serviços de saneamento básico, portanto, se encaixam nesta definição, pois são aqueles relacionados à captação, reservação e distribuição de água, coleta e tratamento de esgotos sanitários domésticos e industriais, sendo de suma importância para a manutenção das condições sanitárias adequadas à reprodução da vida humana, principalmente em condições de aglomerações populacionais, como ocorre nas áreas urbanas.

Apesar das áreas rurais também demandarem condições sanitárias para a melhoria da qualidade de vida e do meio, são nas áreas urbanas que os serviços de saneamento básico são vitais. Nas áreas urbanas, em virtude da alta densidade populacional e dos espaços reduzidos dos lotes é inviável em grande parte a adoção de medidas sanitárias isoladas, como fossas e poços.

Entretanto, deve ser observado que o abastecimento das aglomerações populacionais por meio de redes de distribuição de água e esgoto também contribuiu historicamente para a dissociação entre a água servida e a água dos mananciais.

À medida que foram sendo desenvolvidos os serviços de saneamento básico e facilitadas as atividades produtivas nas aglomerações urbanas, estas puderam se expandir para áreas cada vez mais distantes dos mananciais. O afastamento das 
populações dos cursos d'água, ao mesmo tempo que tem gerado novas e complexas demandas, também de certo modo, contribui para a perda da percepção em relação à qualidade dos recursos hídricos.

Segundo Rocha (1997), em São Paulo há cerca de 1500 cursos d’água canalizados ou contaminados, que não mais integram a vida da população, excetuandose em momentos de chuvas intensas quando as enchentes causam prejuízos. Neste caso, percebe-se que o afastamento das populações do contato com a água induz não somente a perda da percepção acerca da espacialidade quanto ao traçado original dos cursos d’água, dos volumes e da qualidade da água, mas também impedem que sejam concebidas soluções que incluam a participação da coletividade. Deste modo, a sociedade civil tem se afastado da participação nas tomadas de decisão quanto à gestão dos recursos hídricos e dos serviços vinculados à água. Isto contribui para que os interesses privados assumam posição de destaque na articulação do processo de transferência dos serviços de saneamento básico à iniciativa privada.

Enquanto predominava a idéia de abundância a preocupação com a qualidade da água praticamente inexistia. Porém, ao se ampliarem as discussões sobre a diminuição da disponibilidade de água inicia-se um processo de avaliação mais cuidadoso sobre a distribuição da água doce na Terra, consumo e comprometimento dos mananciais.

Nas últimas duas décadas tornou-se evidente a crescente poluição dos recursos hídricos, advindas de fontes diversas, tais como: de agrotóxicos, de efluentes domésticos e industriais e da lavagem das ruas, como tratado por Branco (1981).

Bem como a problemática do crescente comprometimento dos recursos hídricos, a preocupação com o aumento das demandas por água passou a ser considerada, já que as reservas continuam as mesmas, ou até menores, em função dos problemas de contaminação já mencionados.

É importante lembrar que o reconhecimento da problemática acerca do comprometimento dos mananciais de água, bem como do uso indiscriminado de recursos naturais vêm se inserindo nas discussões de cunho ambiental desde início da década de 1970, em Assembléia da Organização das Nações Unidas - ONU. Nota-se que a idéia de "crescimento zero" lançada em 1972, foi rechaçada e, de certo modo substituída pela idéia de “desenvolvimento sustentado”, apresentada em 1992, na Conferência das Nações Unidas para o Desenvolvimento Humano. 
A idéia de desenvolvimento sustentado, no que diz respeito ao uso dos recursos naturais, por sua vez, pressupõe equilíbrio e eqüidade. No que se refere à água o equilíbrio está associado ao uso parcimonioso e a eqüidade ao direito de todos de terem suas necessidades básicas satisfeitas. Contudo, a fundamentação do acesso à água a partir da via econômica não garante estes pressupostos porque ao relacionar o acesso a partir da possibilidade de pagamento pelo consumo de água se assume homogeneização da renda, das culturas, dos padrões de consumo e mesmo da quantidade de água disponível a essas populações, o que não condiz com a realidade. Deste modo, consome mais quem pode pagar mais e, portanto, o uso parcimonioso só afeta as populações mais pobres, ou seja, aquelas que em geral já têm acesso restrito à água. Também o equilíbrio inexiste, já que este pressupõe igualdade na capacidade de pagamento.

A realidade mostra que grande parte da população de vários países sofre privação de água não somente devido à ausência de fontes de mananciais em seu território, mas, também, devido à incapacidade econômica de acessá-las e de competir economicamente com usos mais lucrativos. A lógica econômica, portanto, prioriza o consumo e o atendimento das demandas mais lucrativas.

Deste modo, os países mais desenvolvidos industrialmente continuam consumindo mais água do que aqueles com economia baseada em atividades primárias.

Em relação à evolução das demandas mundiais por água, é possível inferir com base em dados sobre as perspectivas de uso da água em relação às potencialidades de ocorrência em 2025, expostos por Rebouças (1999, p.18), que grande parte dos países da Ásia e Norte da África utilizarão mais de 40\% da água que ocorre em seu território. Os Estados Unidos, juntamente com seu Estado do Alaska e alguns países da Europa utilizarão entre $20 \%$ e $40 \%$ da água existente, ao contrário da América do Sul como um todo que apresentará um consumo de menos de $20 \%$ de sua produção natural. Isto quer dizer que ao se perpetuarem estas estruturas de consumo, as reservas sul-americanas pouco utilizadas, mesmo que distantes dos grandes centros de consumo, serão potenciais áreas de exploração futura, sofrendo pressões de uso cada vez maiores.

Não podemos deixar de notar que essa estrutura de consumo tem criado e acirrado conflitos entre diferentes nações ao longo do tempo, sendo que muitos destes conflitos ainda se estendem na atualidade. Renner (1989) cita em seu trabalho o conflito entre o Egito, o Sudão, a Eritréia e a Etiópia sobre o uso do rio Nilo, da Síria, Líbano, Jordânia, Israel e Palestina sobre o uso do rio Jordão, o conflito entre os Estados Unidos 
e o México sobre o uso do rio Grande, entre a Índia e Bangladesh sobre o consumo do rio Ganges-Bramaputra, entre outros.

Ao contrário de muitos países onde a água é ou torna-se escassa, o Brasil está hoje entre os maiores produtores de água doce no mundo, apesar das crises advindas de uma escassez qualitativa, especialmente nas grandes metrópoles. Deste modo, como ressaltado por Rebouças:

(...) o Brasil destaca-se no cenário mundial pela grande descarga de água doce dos seus rios, cuja produção hídrica, $177.900 \mathrm{~m}^{3} / \mathrm{s}$ e mais $73.100 \mathrm{~m}^{3} / \mathrm{s}$ da Amazônia internacional, representa 53\% da produção de água doce do continente Sul Americano (334.000 m³ $/ \mathrm{s})$ e $12 \%$ do total mundial $\left(1.488 .000 \mathrm{~m}^{3} / \mathrm{s}\right)^{3}$.

Tendo em vista a grande ocorrência de água em território brasileiro e o aumento das demandas mundiais, são postos alguns questionamentos sobre as perspectivas de uso da água e sobre o poder de decisão sobre este uso, tais como: Quem explorará as fontes? Como serão essas explorações? Quem serão os beneficiados? Haverá equidade na distribuição? Os conflitos relacionados ao controle da água crescerão?

Apesar deste trabalho não responder todas estas questões, algumas delas serão discutidas, já que ao buscarmos a compreensão sobre a atuação de empresas privadas ligadas ao grupo Suez S.A. nos serviços de saneamento básico no Brasil, são avaliados os interesses envolvidos, o atendimento das demandas, bem como os impactos da atuação destas empresas no meio ambiente.

O objetivo deste trabalho, portanto, é o de analisar as concessões de saneamento básico obtidas pelo grupo transnacional Suez S.A., em Limeira-SP e Manaus-AM e de desvendar como essas concessões integram as novas estratégias de negócios deste mesmo grupo.

Para alcançar o objetivo proposto são discutidas como se estruturam as novas relações em torno da água a partir de um contexto de escassez. Também são analisados e discutidos os mecanismos financeiros utilizados pelo grupo para seu fortalecimento e expansão e sua inserção, por meio das concessões, em localidades financeiramente dependentes e necessitadas de investimentos em serviços de saneamento básico. Ainda,

${ }^{3}$ REBOUÇAS, Aldo da Cunha. Água Doce no Mundo e no Brasil. In: REBOUÇAS, A.C.; BRAGA, B. $e$ TUNDISI, J.G. (Orgs) Águas Doces no Brasil. Capital Ecológico, Uso e Conservação. São Paulo: Escrituras, 1999, p.29. 
são avaliadas as políticas públicas de saneamento básico nos dois municípios e a atuação das empresas, por meio da análise da evolução dos serviços e da análise da percepção das comunidades diretamente envolvidas sobre a qualidade dos serviços e do atendimento das demandas.

Sob o ponto de vista da análise das políticas públicas no Brasil, de um lado, observamos uma diminuição da atuação do Estado, na oferta de infra-estrutura necessária ao suprimento das demandas crescentes por serviços de saneamento básico, posição esta, coerente com as políticas de Estado mínimo delineadas principalmente pelos governos Estadual e Federal, já a partir dos anos 1990. De outro, verificamos, ao nível mundial, o crescimento e fortalecimento de grandes grupos econômicos, sobre o qual Tabb (1997) discute em seu artigo sobre globalização e o poder do capital. Estes grupos econômicos estão ligados ao setor financeiro e se utilizam da possibilidade de ação nos chamados mercados livres para ampliar seu capital e poder. Mas, como observa o autor, as possibilidades de controle existem por meio das formas de regulação do capital pelo Estado e isto é uma escolha política.

Deste modo, buscamos introduzir estudos de caso no intuito de desvendar a ação dos grupos transnacionais no setor de saneamento básico. É importante compreender que apesar deste trabalho a princípio retratar condições político-econômicas locais, deve-se ter claro que as ações pontuais estão ligadas entre si, conformando o poder por meio do fortalecimento dos fluxos e da centralização do capital, caracterizando, portanto, o interesse dos grupos transnacionais as quais as empresas locais estão ligadas.

Como os serviços de saneamento básico, assim como a gestão de recursos hídricos do território brasileiro são incumbências do Estado, a concessão destes serviços à iniciativa privada só ocorre como resultado de decisões político- administrativas.

Neste sentido, a atuação do Estado no Brasil será analisada pelo prisma das políticas públicas de saneamento básico. Políticas públicas estas relacionadas ao desenvolvimento das ações normativas, de instrumentação das instâncias fiscalizadoras e reguladoras e da participação da sociedade civil organizada, já que a nosso ver estes fatores constituem a base das resistências, que poderão condicionar a atuação dos grandes grupos transnacionais aos interesses sociais, ou das fragilidades que permitirão a atuação dos grandes grupos em seu próprio benefício.

Façamos um parêntesis aqui para esclarecer que a definição de "Estado” adotada neste trabalho é o desenvolvido em Gramsci (1974). Para o autor o Estado seria 
constituído por representações da sociedade organizada em classes, que por sua vez seriam responsáveis pela elaboração e difusão de ideologias pelas quais se busca exercer a hegemonia. Contudo, lembramos que estas representações não são homogêneas e as políticas de Estado, desse modo, vão expressar estratégias de acumulação ou de distribuição de acordo com os interesses dominantes.

É importante, neste sentido compreendermos as instâncias públicas não somente como expressão da representação dominante ou como sinônimo de interesses individuais privados, mas como espaço onde são travadas lutas entre interesses sociais e interesses particulares.

Neste trabalho, os interesses particulares são caracterizados pelo grupo transnacional Suez S.A. e, para tanto, devemos discorrer mais detalhadamente sobre a importância deste grupo no setor de saneamento básico e sua ligação com outros setores da economia.

Particularmente no caso da água, o grupo francês Suez S.A. (ex. Lyonnaise des Eaux), possui o maior número de subsidiárias, atuando em mais de 70 diferentes localidades e atua no Brasil, em pelo menos, duas cidades para prestação de serviços de saneamento básico: em Limeira - SP, por meio da empresa “Águas de Limeira” e em Manaus - AM, por meio da empresa “Águas do Amazonas”. Também atuou em Campo Grande - MS, por meio da empresa “Águas de Guariroba”, controlada temporariamente pelo grupo Águas de Barcelona, conhecido como “Agbar”, sendo que esta última se retirou das operações dos serviços nesta cidade em 2005.

Entre as subsidiárias brasileiras que atuam até a presente data, ligadas ao setor de saneamento básico consta, a partir de 1995, a concessão da gestão e prestação dos serviços de saneamento básico no município de Limeira - SP e, em 2000 a concessão da gestão e operação dos serviços de saneamento básico em Manaus - AM.

A dificuldade em relacionar as empresas subsidiárias ao grupo controlador repousa no fato de que, em geral, elas mantêm denominações diferenciadas e há compra e venda de ações entre empresas do grupo e fusões constantes. A possível a correlação de uma empresa ao grupo somente pode ser considerada por determinados períodos, mediante investigação contábil, por meio da mídia ou do acompanhamento das próprias páginas eletrônicas das empresas.

Como exemplo disto, podemos citar o caso do grupo “Ondeo”, que apesar de já existir na prática, como uma espécie de coordenação das empresas associadas ligadas ao 
grupo Suez Lyonnaise des Eaux (atualmente Suez S.A.) o mesmo teria sido oficializado em 2001 pelo grupo controlador Suez S.A. como articulador de todas as transações relacionadas às suas atividades classificadas como "ambientais”, ou seja, as atividades relacionadas ao saneamento básico, à energia e aos resíduos.

Em 2000, a “Ondeo Services” aparecia no organograma simplificado da Suez, apresentado na página eletrônica da Suez S.A, como controlador das ações (25,8\%) da empresa Agbar e da empresa Lyonnaise des Eaux France.

A Agbar, por sua vez, era quem detinha $50 \%$ das ações da empresa “Águas de Guariroba” em Campo Grande, até 2005. Deste modo, ao se desvendar o jogo acionário entre as empresas deste grupo, nota-se que a Águas de Guariroba se relacionava ao grupo Suez S.A. por meio da Ondeo Services.

A título de auxiliar a compreensão sobre a prioridade de interesse do grupo Suez e compreender as razões envolvidas no abandono de um ponto também estratégico do ponto de vista de ocorrência de água no Brasil, procuramos discutir sucintamente a seguir sobre o caso de Campo Grande.

Como supracitado, em Campo Grande, a Águas de Barcelona - Agbar (empresa com participação de ações do grupo Suez) possuía 50\% das ações da empresa Águas de Guariroba, que era a empresa criada para operar os serviços de saneamento básico em Campo Grande. As demais empresas associadas eram as brasileiras Cobel que possuía $41 \%$ e a Sanesul com $9 \%$.

Segundo divulgado pelo Jornal da Associação Brasileira da Infra-estrutura e Indústrias - Abdib, em meados de 2005 tornou-se aparente o conflito entre os sócios da Agbar e da Cobel envolvendo o controle acionário da empresa, já que conforme divulgado não havia consenso sobre o valor das ações que deveriam ser vendidas pela Cobel para a Agbar. Este fato coloca em cheque as prioridades dos grupos concessionários privados já que, como observado por Souza, este conflito de interesses financeiros “(...) estaria levando ao descumprimento das metas de investimentos e de expansão”4, o que não tem a ver com a falta de regulação do setor.

Como a empresa Agbar não obteve o controle acionário da empresa “Águas de Guariroba”, ela decidiu abandonar a concessão em Campo Grande, transferindo suas

\footnotetext{
${ }^{4}$ SOUZA, Paulo Henrique. Insegurança espanta capital estrangeiro. Jornal da ABDIB, São Paulo, 23 de setembro de 2005.2 Disponível em: www.abdib.org.br/noticias_lista_ultimas.cfm?id_noticia=1349> Acesso em 23 de setembro 2005.
} 
ações às duas empresas brasileiras: a Bertim e a Equipav, a primeira ligada a atividades frigoríficas e a segunda às atividades sucroalcoleiras. Estas empresas possuem atualmente $81 \%$ das ações da Águas de Guariroba, sendo que 50\% foi obtida da Agbar e 31\% obtida da Cobel, que continuou com 10\%.

As outras concessões de serviços de saneamento obtidas no Brasil, em Manaus e em Limeira, continuam sob o controle do grupo Suez S.A..

É interessante mencionar o aspecto contraditório do evento que culminou com a saída da Agbar de Campo Grande. Estes dizem respeito à contradição dos discursos de representantes das empresas do grupo e à tentativa de dissociar a Agbar do grupo Suez S.A. Essa tentativa de dissociação é clara na contradição entre a fala de Newton de Lima Azevedo ${ }^{5}$ e Fernando Mangabeira Albernaz. Na fala de Newton de Lima Azevedo, as empresas privadas estavam dispostas a sair do país em função da indefinição da política de regulação do setor de saneamento básico.

Em contraposição, Fernando Mangabeira Albernaz, diretor presidente da “Águas de Limeira” procurou mostrar que não fazia parte dos planos da Suez S.A. no Brasil abandonar os serviços de saneamento básico.

Ainda, houve esforços por parte do diretor presidente da “Águas de Limeira”, Fernando Mangabeira Albernaz, em dissociar a empresa Agbar do grupo Suez S.A. Segundo Souza (2005) este alto funcionário da “Águas de Limeira” afirmou que "O grupo Suez não estaria pensando em sair do país, como já fez na Argentina há pouco mais de uma semana” e completa "Aqui não existe esta discussão"6.

Paira a dúvida sobre o termo “aqui” utilizado. Se "aqui” se referir às empresas do grupo Suez S.A. há uma evidente contradição, já que este grupo possuía ações da Agbar e, portanto, pressupõe-se alguma participação e certa cumplicidade na decisão de retirada do grupo na operação dos serviços.

Certamente a afirmação procurou dissociar a Agbar das demais do grupo em uma tentativa de proporcionar segurança aos acionistas das empresas “Águas do

\footnotetext{
${ }^{5}$ Newton de Lima Azevedo além de ser vice presidente da ABDIB, ocupou o cargo, até 2005, de diretor presidente da Degremont Brasil e de vice-presidente da Degremont América do Sul e, até 2003, foi diretor presidente da D.R.M.A Empreendimentos e Participações Ltda, que é a subsidiária que controla a Águas do Amazonas em Manaus.

${ }^{6}$ SOUZA, Paulo Henrique. Insegurança espanta capital estrangeiro. Jornal da ABDIB, São Paulo, 23 de setembro de 2005. Disponível em:<http: www.abdib.org.br/noticias_lista_ultimas.cfm?id noticia=1349> Acesso em 23 setembro 2005.
} 
Amazonas” e “Águas de Limeira” e minimizar desgastes de confiabilidade sobre a capacidade de assunção dos compromissos firmados pelo grupo em cidades brasileiras.

Se a mudança de denominação, por um lado faz parte das estratégias desenvolvidas pelas grandes corporações transnacionais para minimizar problemas com sua imagem, por outro também fornece indícios sobre a ocorrência de novas fusões e incorporação de capitais.

A atual Suez SA já recebeu várias denominações devido à fusão de várias empresas. Pode-se afirmar que as associações entre empresas são antigas, mas a evolução para fusões com compra de ações de uma empresa por parte de outra evoluiu de forma crescente a partir de meados da década de 1980.

Algumas empresas que podem ser relacionadas diretamente ao grupo controlador transnacional Suez S.A. no setor de saneamento básico são a Lyonnaise des Eaux, a Companhia Suez, a Sociedade Geral da Bélgica, a United Water, a Ondeo e atualmente a Suez Environment.

Em 1997 a Suez foi denominada "Suez Lyonnaise des Eaux", por ter sido resultado da fusão entre a Companhia Suez e a Lyonnaise des Eaux e em 2001 após ter incorporado as ações de várias empresas e se transformado em um grande grupo transnacional passou a ser denominada Suez.

Ainda, em 2001 a Suez lançou a marca Ondeo para seus serviços relacionados à água, Fluxys para as atividades de transporte e Tractebel passou a ser responsável pelo setor de energia. Neste mesmo ano a Suez foi incluída na Bolsa de Nova York.

Em 2002 foi criada a linha de negócios “ambientais” da corporação, onde aparecem os nomes da Ondeo, SITA (Sociedade Industrial de Transportes Automobilísticos) e Degrémont.

Finalmente, em 2005 a estrutura do grupo controlador Suez S.A. passou a ser subdividido em cinco frentes de trabalho com a denominação Suez em cada uma delas, com o intuito de valorização da marca. São elas: Suez Energy Europe, Suez Energy International, Suez Energy Services e Suez Environment, esta última contemplando o setor de saneamento básico.

Os organogramas a seguir procuram representar a estrutura do grupo Suez S.A. em 2000 e a proposta para 2005.

Lembramos que as subsidiárias internacionais são inúmeras, representadas por empresas que controlam as ações das empresas no âmbito local. No Brasil para o caso 
da “Águas do Amazonas” a subsidiária é a DRMA Empreendimentos e Participações S.A. e para o caso da "Águas de Limeira” as subsidiárias, até meados de 2006, eram a Lumina Engenharia Ambiental Ltda e a Suez Environment S.A. A Lumina Engenharia Ambiental Ltda substituiu em 2005 a posição ocupada pela CBPO (Odebrecht) e a Suez Environment S.A. substituiu a Ondeo Services S.A.

FIGURA 1. Organograma Suez S.A.

SUE7 LYONNAISE DES EAUX (9000)
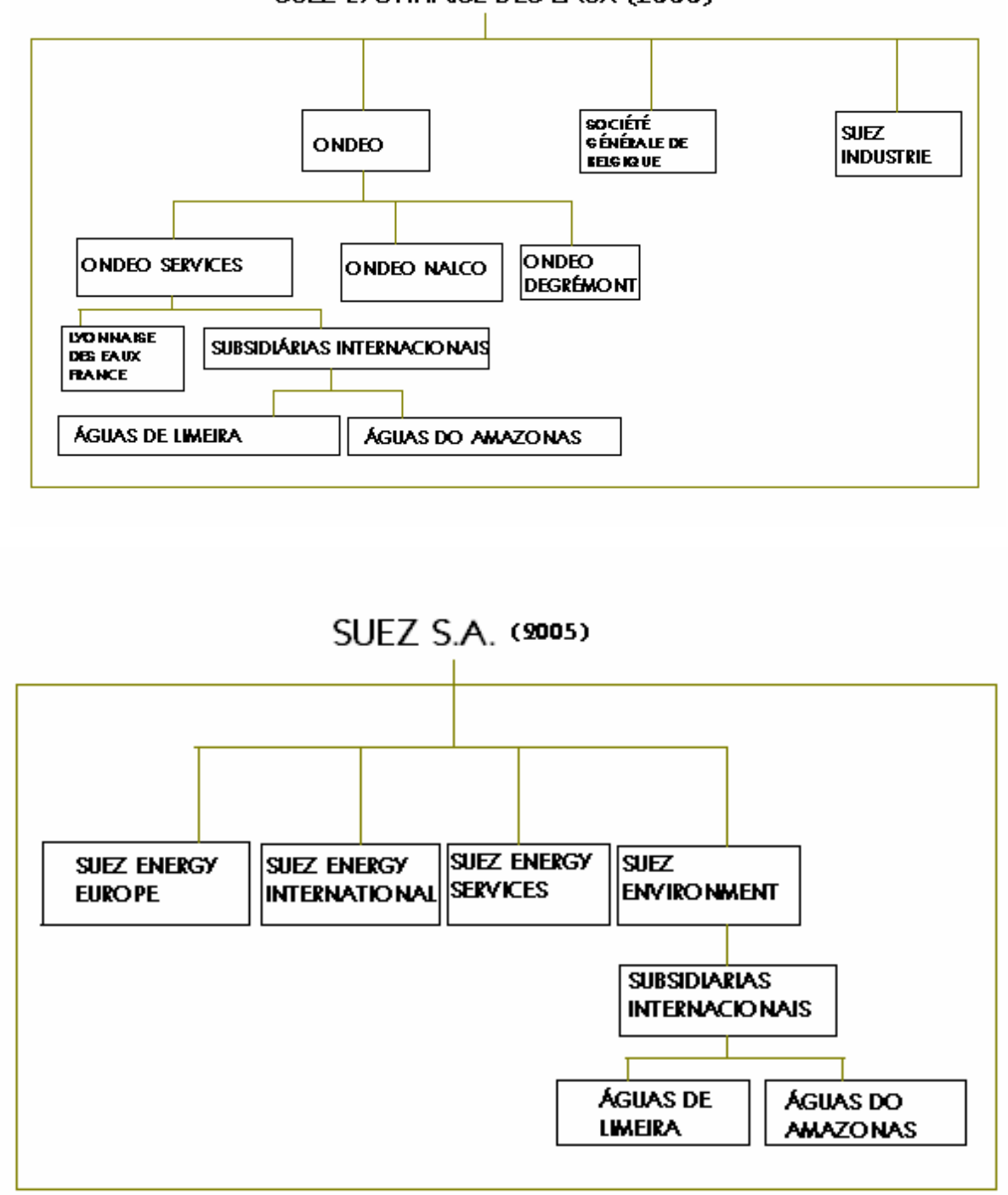

O grupo Suez, os demais grandes grupos transnacionais prestadores de serviços caracterizam-se pela diversificação de suas atividades, atuando, por exemplo, na área de 
infra-estrutura, energia e de transportes, através de coligações com grandes empresas, internalizando-as verticalmente.

Conforme foi possível observar nos organogramas o grupo Suez atua nos setores de energia, comunicação, tratamento de resíduos, entre outros, além do setor de saneamento básico. No Brasil, algumas das empresas trabalham associadas ao grupo, prestando serviços relacionados à venda de produtos químicos, obras, etc. Entre algumas que podem ser citadas constam a Odebrecht Serviços de Infra-Estrutura SA, as empresas do grupo Vega Engenharia e a Lumina Engenharia Ambiental Ltda.

Além do grupo Suez S.A. outros grupos transnacionais, ligados aos serviços de saneamento básico, também expandiram seus mercados de atuação para o exterior dos paises de origem, podendo ser citados: o grupo francês Veólia Environnement (Ex Vivendi) com grande peso internacional no setor de saneamento básico, os grupos ingleses North West Water e Tames Water, o grupo espanhol Águas de Barcelona (Agbar), entre outros.

Em geral, o interesse destes grandes grupos se volta às cidades com populações maiores de 50.000 habitantes, e em especial para as metrópoles, onde a possibilidade de lucro com os serviços é maior. Mas, deve-se ponderar que o tamanho da população, ou seja, o número de consumidores em potencial, não é o único elemento que pode atrair o interesse destes grupos.

Lembramos que o tipo de concessão, onerosa ou não, as necessidades de investimento em infra-estrutura, o poder de pagamento da população e a importância da área em relação à ocorrência de água também contam.

Como abordado há dois tipos de concessão, na concessão onerosa há necessidade de pagamento de um valor estipulado para a obtenção do direito de exploração dos serviços e a não onerosa não envolve cobrança de direitos de exploração dos serviços. Para o segundo caso, em geral, são definidos critérios para seleção da empresa que irá prestar os serviços, como capacidade técnica, menor tarifa a ser aplicada, etc.

Baseando-nos nestes fatos, procuraremos discutir e aprofundar neste trabalho as razões que motivaram o grupo Suez S.A a pleitear a concessão dos serviços da cidade de Manaus e de Limeira, levantando os fatores positivos e negativos de atratividade existentes para o grupo transnacional e sua relação com a evolução na prestação de serviços de saneamento nas duas cidades abordadas. 
Para desenvolvermos estas discussões, procuraremos considerar o contexto em que as concessões ocorreram quanto às políticas públicas do setor e quanto à evolução das demandas e da oferta dos serviços de saneamento básico. Neste sentido, deve-se ter claro que os serviços de saneamento básico no Brasil, em especial em cidades médias do interior e até em algumas capitais, como é o caso de Manaus, têm sofrido crescentes demandas, em virtude do rápido crescimento populacional e urbano, o que requer efetividade nas políticas públicas para o setor.

Por sua vez, a efetividade das políticas públicas do setor de saneamento básico requer uma articulação sistêmica entre diversos órgãos e diferentes instâncias de gestão. Esta articulação, por sua vez, não é tarefa simples já que envolve alinhamentos políticos diversos, bem como poder de investimentos também diferenciados.

A dificuldade de articulação e de efetividade das políticas públicas no setor de saneamento básico, associado ao crescimento das demandas, tem contribuído para a dificuldade de aplicação dos investimentos necessários e para a perda de controle sobre a qualidade dos serviços.

As questões da viabilização dos investimentos e do controle da qualidade dos serviços de saneamento básico no Brasil abriram as grandes controvérsias no que tange a concessão destes serviços às empresas pertencentes a grandes grupos econômicos transnacionais. Por um lado há aqueles que defendem que seria a forma mais eficiente de possibilitar investimentos rápidos, já que o Estado tem diminuído a destinação de recursos para este fim. Há também aqueles que apóiam a iniciativa privada com a argumentação do domínio da capacidade de renovação tecnológica, que contribuiria para a qualificação da força de trabalho e, finalmente há aqueles que pressupõem que a atuação de empresas privadas elevaria a produtividade e a qualidade dos serviços.

Por outro lado há autores, como Castro (1999) que apontam para os efeitos negativos da privatização do setor de saneamento básico, entre os quais a superexploração das reservas de água e a super-taxação. Outros como Britto (2001) levantam questões sobre o abandono dos investimentos em esgotamento sanitário por serem eles mais onerosos e não proporcionar retorno tal qual o abastecimento de água. Outros, ainda, como Vargas e Lima (2004) observam a fragilidade da regulação para o caso brasileiro. De modo geral, há autores enfáticos em sua crítica à privatização dos serviços, como Sodré (1999). Segundo este autor o processo de privatização dos 
serviços públicos daria continuidade ao processo de exploração socioeconômica historicamente construída por parte de interesses privados internacionais.

Desse modo, ao questionarmos em que medida a prestação de serviços de saneamento básico no Brasil por meio das concessões de Limeira e de Manaus pode ser atraente ao grupo transnacional Suez S.A., estaremos revelando alguns aspectos que podem contribuir para a compreensão acerca das perspectivas de investimentos do setor de saneamento básico e do atendimento das demandas por esses serviços.

Nossa hipótese é a de que a atuação de grandes grupos transnacionais no setor de saneamento básico no Brasil, a exemplo do Suez S.A., se expressaria pela busca de obtenção de lucratividade e pela priorização de grande rendimento financeiro em detrimento do atendimento das demandas locais por serviços de saneamento básico. A lucratividade seria obtida por meio de aplicação de altas tarifas, estímulo ao consumo e parcos investimentos no setor e os altos rendimentos seriam viabilizados por meio das transações financeiras envolvendo fusões e incorporações, captação de novos investidores e crescimento das ações do grupo nas bolsas de valores.

Vislumbrando uma possível contribuição à discussão sobre o processo de privatização dos serviços de saneamento básico no Brasil, a partir da avaliação de concessões já efetivadas, é que foram tomados como parâmetros os casos de Manaus e de Limeira, já que o grupo Suez S.A., por seu porte, tempo de experiência e grau de influência, demonstrou ser bastante significativo no que diz respeito à ilustração da atuação privada no setor de saneamento básico no Brasil.

A primeira etapa deste trabalho foi ocupada com o levantamento de informações em banco de dados, do Instituto Brasileiro de Geografia e Estatística - IBGE e do Sistema Nacional de Informações sobre Saneamento - SNIS, de onde foi possível traçar a evolução dos serviços em cada uma das cidades abordadas.

Buscando obter informações mais atualizadas e conhecer a realidade do atendimento das demandas em cada uma das cidades (Manaus e Limeira), foi efetuado trabalho de campo. Neste trabalho de campo, foi aplicado um questionário direcionado a uma população amostral previamente selecionada, na qual se procurou obter informações sobre a percepção desta população em relação ao atendimento prestado pelas empresas privadas em questão. Este trabalho de campo também proporcionou o reconhecimento das características físicas locais, o que auxiliou a compreender melhor as complexas relações sócio-ambientais relacionadas ao saneamento básico. 
Procuramos, também, analisar a evolução das movimentações financeiras das duas empresas brasileiras, a Águas de Limeira e Águas do Amazonas, por meio de seus balanços financeiros publicados, bem como o comportamento de investimentos do grupo e a evolução de suas ações no mercado de capitais.

No primeiro capítulo são discutidas como se configuram as novas modalidades de negócios em torno da água, que se amparam principalmente na idéia de escassez e na valoração econômica da água.

No segundo capítulo procurou-se discorrer sobre a experiência de regulação dos serviços de saneamento básico no âmbito internacional e discutir de forma mais aprofundada a questão da regulação dos serviços de saneamento básico no Brasil, bem como as estratégias privadas para a reprodução ampliada do capital que se desenrolam por meio do controle da água a partir das concessões de serviços de saneamento básico.

Finalmente, no terceiro capítulo, buscou-se discorrer sobre o desenvolvimento das políticas de saneamento básico em Limeira e Manaus frente a um quadro de fragmentação das políticas setoriais e analisar a evolução dos serviços de saneamento básico em Limeira e Manaus. A análise da evolução dos serviços, por sua vez, procura contribuir para o reconhecimento dos interesses da empresa, bem como para a avaliação do atendimento das demandas. 
CAPÍTULO I

A valoração e o consumo da água 
Nos dias atuais discutir sobre temas que envolvem ações humanas sobre a água nos remete a uma complexa tarefa já que são inúmeras as possibilidades de abordagens. Como nosso objetivo neste capítulo é buscar caracterizar as relações sociais e econômicas que se desenvolveram em torno deste elemento natural, optamos por iniciar esta tarefa com a discussão de questões concernentes à sua disponibilidade e ao seu acesso.

A diminuição da disponibilidade da água implica em necessidade de mudança de comportamento e, em provável valorização deste bem. Esta valorização por sua vez, pode ser resultado de diferentes valorações. Deste modo, dependendo do tipo de valoração atribuída à água seu consumo pode ser restringido em maior ou menor grau e sua disponibilidade pode ser alterada.

Devemos esclarecer que a noção de valoração aqui considerada se remete diretamente a emissão de juízo de valor, de importância. A valoração da água pode ser representada pela corrente que a defende como bem comum e a conscientização sobre seu uso pode ocorrer por meio da informação e educação e também pode ser representada pela corrente que a defende como um recurso natural expresso por seu valor econômico, e, assim sendo seu consumo poderia ser controlado pelo preço.

Neste sentido, procuramos discorrer neste capítulo como se aplicam estas formas de valoração, em especial no que diz respeito à transformação da água em um recurso econômico estratégico para a reprodução privada do capital.

Ao traçar o panorama atual e as perspectivas futuras do uso da água buscamos incorporar discussões sobre a questão da escassez, sobre o consumo e suas categorias, sobre a gestão dos serviços de saneamento básico e sobre a criação de um mercado para a água. O objetivo destas discussões é compreender a valorização da água e o processo de privatização dos serviços de saneamento básico no Brasil.

As categorias sobre consumo da água adotadas comumente apresentam-se divididas em consumo industrial, consumo agrícola e consumo doméstico. Deve-se ressaltar que a categoria de consumo doméstico abrange não somente as residências por si só, mas também todas as categorias incluídas no setor terciário como comércio e serviços. Assim, neste trabalho, todas as vezes que se falar em consumo doméstico da água entenda-se o consumo abrangido pelas categorias residenciais, de comércio e de serviços. 


\section{A disponibilidade de água}

É milenar o conhecimento sobre a importância da água enquanto fonte de vida e matéria prima para produção, mas é recente o conhecimento preciso sobre sua distribuição natural, bem como a conscientização ambiental no que tange a preocupação com o uso equilibrado de suas reservas.

Ainda, são relativamente imprecisos os dados sobre os volumes de água doce disponível, bem como o comprometimento de suas reservas, o que dificulta deveras uma avaliação definitiva sobre a capacidade de atendimento das demandas futuras.

Segundo a Organização das Nações Unidas para a Educação, Ciência e Cultura Programa Hidrológico Internacional - ONU/UNESCO/PHI, a Terra dispõe de aproximadamente 1,386 milhões de $\mathrm{km}^{3}$ de água, distribuídos em mares, lagos, rios, aqüíferos, gelo, neve e vapor. Ainda, de acordo com Rebouças (2004, p.32) apenas 2,5\% deste volume de água, ou seja, cerca de 34,65 milhões são de água doce. Em relação a este total de água doce ainda devemos subtrair os volumes não disponíveis para o consumo humano, ao menos de imediato, como as calotas polares e geleiras que somam aproximadamente 24 milhões de $\mathrm{km}^{3}$, ou seja, 68,9\%. Restam, portanto, cerca de 10,55 milhões de $\mathrm{km}^{3}$ disponíveis sobre a superfície e nas reservas subterrâneas.

Deste total disponível se conhece também os volumes distribuídos no planeta, mas ainda são incertos os cálculos sobre o consumo desta água, especialmente em relação aos volumes procedentes das fontes subterrâneas. Ainda, as alterações climáticas e as interferências humanas sobre o meio físico também têm influenciado fortemente na dinâmica hídrica natural gerando, consequentemente mais incertezas.

Neste contexto de imprecisão Rebouças (2004) chama a atenção também para dois aspectos em relação aos quadros alarmistas que apontam cenários catastróficos de rápido esgotamento das reservas de água doce do planeta: o primeiro é o da desconsideração de várias alternativas que podem contribuir para evitar o problema da escassez, como o do reuso e do uso integrado das águas pluviais, das reservas superficiais e subterrâneas, e, o segundo, é o da falta de fundamentação sobre a hidrologia, já que sobre a água há muitas estimativas e poucos dados efetivamente confiáveis.

Rebouças (2004, p.189) chega mesmo a mencionar que a ONU estaria manipulando a "Estratégia da Escassez", mas atribui esta manipulação ao fato de que o 
organismo remete sempre aos países “subdesenvolvidos” o ônus desta escassez, deixando de considerar "os problemas resultantes do crescimento excessivo das demandas nos países desenvolvidos e, sobretudo, da degradação da sua qualidade”.

Sem dúvida, a crítica elaborada pelo autor não é sem razão, mas procuraremos neste trabalho aprofundar um pouco mais um outro sentido desta manipulação pela denominada "Estratégia da Escassez".

No contexto deste trabalho a estratégia da escassez está relacionada às estratégias dos interesses econômicos transnacionais que buscam não somente a obtenção de lucro com a exploração da água em si, mas também a possibilidade de obtenção de rentabilidade por meio da transformação da água em negócio.

Mas esta estratégia é relativamente recente e para que possamos compreendê-la melhor não podemos deixar de resgatar, historicamente, a discussão sobre o esgotamento dos recursos naturais de um modo geral.

No contexto da discussão sobre o esgotamento dos recursos naturais, nos finais da década de 60 o movimento ambientalista ganhou corpo e credibilidade em relação aos representantes políticos, aos agentes econômicos e à sociedade civil em geral graças às novas informações científicas produzidas com base em novas técnicas. Munidos de instrumentos novos, graças à evolução tecnológica e científica, a exemplo do avanço na cartografia e do uso de imagens de satélite passou a ser possível monitorar a dinâmica espacial do planeta e mensurar com maior precisão as alterações ambientais que ocorriam especialmente sobre os meios físicos e bióticos.

Lauber (1990, p. 6) lembra que a Apollo 8, lançada em 21/12/68, iniciou uma revolução na cartografia com a utilização das imagens da Terra obtidas a partir do espaço, proporcionando entre outras coisas, a visão total do comprimento dos rios, da altura e cobertura das montanhas mais altas, do surgimento dos furacões, das estreitas estradas e dos limites que marcam as cidades do mundo.

Associada a esta tecnologia também o desenvolvimento da informática com a agilização no processamento de dados e possibilidade de elaboração de avaliações mais aprofundadas por meio de Sistemas de Informação Geográficas, contribuiu para que as previsões de cunho ambiental fossem mais bem aceitas.

Pode-se dizer que o desenvolvimento tecnológico e científico atuou eficazmente no fortalecimento do movimento ecológico, a partir do final da década de 1960, mas foi 
sem dúvida a crise do petróleo em 1973, que impulsionou sobremaneira a crítica ambientalista, que previa o rápido esgotamento dos recursos naturais mundiais.

Os impactos ambientais sentidos por vários países e também no Brasil, advindos dos desequilíbrios ambientais e do aumento da poluição também viriam fortalecer o movimento ecológico. Ainda, as críticas desenvolvidas pelos ambientalistas e cientistas aos poucos evoluíram, deixando de focar somente o aspecto físico dos recursos, passando a abordar também o aspecto da má distribuição da riqueza produzida.

Contudo, apesar de inúmeras reuniões internacionais terem sido formalizadas a partir dos questionamentos sobre o esgotamento dos recursos naturais, como aponta Ribeiro (2001, p.146), os resultados práticos mostram-se ainda inexistentes, muito embora o processo de construção de uma estratégia de preservação ambiental por meio da participação de "governos, organismos multilaterais, grupos empresariais transnacionais e o movimento ambientalista internacional” esteja, segundo o autor "em franca elaboração".

Outra característica que se pode também notar é que as poucas soluções adotadas até o momento aos problemas ambientais possuem forte abordagem econômica. Ao exemplo disto é possível citar a adoção dos créditos de carbono como compensação financeira sobre a emissão de poluentes na atmosfera e a cobrança pelo uso da água, tão defendida por representantes das agências de gestão estatais.

Na concepção dos defensores da corrente econômica as soluções propostas aos problemas ambientais sempre envolvem a possibilidade de se introduzir a perspectiva de geração de novos negócios ou de obtenção de lucro. Contudo, grande parte destas propostas calcadas no cunho econômico apresenta contradições. Ao exemplo pode-se citar o caso da compensação da poluição com créditos de carbono que tem por objetivo a diminuição da produção de gazes de efeito estufa. Ao mesmo tempo em que se teria minimizado a ânsia pelo crescimento industrial, por parte daqueles países que ainda contém reservas naturais importantes para a regulação do clima do planeta, ainda é restrito o avanço de ações efetivas para a diminuição dos níveis de poluição por parte dos países industrializados.

Isto aponta o caráter paliativo da solução adotada para o exemplo citado, apesar do avanço no sentido de ser uma das únicas ações efetivamente postas em prática até o momento e, de se proporcionar tempo para a implementação de tecnologias limpas. 
Para o caso da cobrança pelo uso da água, o objetivo principal destacado no item I, do artigo $1^{\circ}$ da Lei n.12.183 de 29/12/05, do Estado de São Paulo é o reconhecimento da água como bem público de valor econômico e também de dar ao usuário uma indicação de seu real valor. Entretanto, o item II do mesmo artigo destaca também o objetivo de obtenção de recursos financeiros para financiamento de programas e intervenções em recursos hídricos, que por sua vez, domina o cenário atual.

Neste sentido, a cobrança pelo uso da água, tem subsidiado projetos com fins de recuperação da qualidade dos mananciais, de recuperação de nascentes, de expansão das redes de coleta de esgotos e implantação de unidades de tratamento de esgotos, de drenagens pluviais, entre outros. Apesar da possibilidade de financiamento de projetos necessários, do ponto de vista ambiental e sanitário, o objetivo primeiro que era o de conscientização, acaba se resumindo à cobrança em si, já que como pode ser observado na página eletrônica do Comitê de Bacias do Piracicaba Capivari e Jundiaí - PCJ $^{7}$-, entre 203 projetos financiados até meados de 2006, apenas 3 possuíam propósito educativo.

Ainda, a despeito dos esforços das Agências de Água, dos Comitês de Bacias e das instituições governamentais relacionadas à gestão dos recursos hídricos, são vários os entraves no que concerne ao controle sobre o consumo das águas superficiais e subterrâneas e sobre a necessidade de aumento da participação da sociedade civil na tomada de decisões.

No que tange ao controle sobre o consumo das águas superficiais e subterrâneas tem havido esforços por parte das Agências de Água e por parte dos Comitês de Bacias, em especial o Comitê Piracicaba, Capivari e Jundiaí - PCJ -, em obter um cadastro de todos os usuários, mas até meados de 2006 ainda era pequeno o número de usuários cadastrados. O cadastro total dos usuários de recursos hídricos do Estado de São Paulo possibilitará a cobrança da água daqueles que se encaixam nos critérios estabelecidos na Lei Estadual n.12.183/05.

No Estado de São Paulo já é efetuada a cobrança de usuários urbanos e industriais desde janeiro de 2006 e há previsão de se iniciar a cobrança para os demais usuários, ou seja, os oriundos das áreas rurais em janeiro de 2010. Por sua vez, estes usuários são os que se encontram irregulares, ou seja, são aqueles que exploram água

\footnotetext{
${ }^{7}$ SÃO PAULO (Estado). Comitê de Bacias Hidrográficas do Rio Piracicaba, Capivari e Jundiaí. In: www.comitepcj.sp.gov.br/Fehidro/PCJ-Geral-Tomador.asp.
} 
subterrânea ou superficial sem outorga de uso pelo Departamento de Águas e Energia Elétrica - DAEE -, sendo possível supor que esta etapa apresentará maiores dificuldades.

Quanto à questão da participação da sociedade civil organizada, é possível afirmar que os Comitês de Bacia prevêem estas representações, porém, tanto os assentos quanto o número de entidades participantes são limitados, o que implica no fortalecimento de interesses privados que mantém sua participação ativa por meio de entidades de classes e mesmo por meio de representações políticas.

No que concerne à questão da água, a concepção econômica ainda esbarra em contradições intrínsecas. Como infere Castro (1999, p. 9-13) as correntes próprivatização fundamentam-se no fato de que o Estado teria deixado de dar um tratamento mercantil em relação à água, causando uma estagnação de preço, enquanto que os custos em aumento da produção, aduções, distribuição etc. estariam em constantes aumentos, gerando um grande ônus para o setor público.

As correntes econômicas pró-privatização criticam o Estado por não ter dado um tratamento mercantil à água, o que causou estagnação no preço ao consumidor, enquanto o custo real do abastecimento de água, da coleta e do tratamento de esgotos crescem, gerando ônus. Contudo, conforme observado pelo autor, a água explorada de forma privada, tampouco se absteria de problemas, tais como a super-exploração e super-taxação, incorrendo ainda em riscos de acirrar os abismos sociais e até de gerar problemas de saúde pública.

Em teoria o objetivo desta corrente econômica seria o de controlar o consumo, ou seja, o alto preço do produto controlaria a demanda, estimulando um consumo equilibrado.

Contudo, esta relação não é tão direta quanto aparenta ser, já que embute alguns problemas sérios entre os quais o da exclusão ao consumo por parte daqueles que não dispõe de recursos para pagar seu alto preço e o fato de que a gestão da água controlada por interesses privados, como observado por Castro (1999) não concorre necessariamente para a lógica de economia de água, podendo implicar em sua superexploração.

Na lógica privada de gestão da água os serviços deveriam ser lucrativos e, portanto, quanto maior o consumo maior a receita obtida por parte dos prestadores de serviços de saneamento, contrariando a valoração da água enquanto recurso escasso e 
que deveria ser consumido com parcimônia. Além disto, as altas tarifas também podem proporcionar lucro e o uso abusivo desta forma de obtenção de lucro pode aumentar a exclusão do acesso à água das parcelas de populações economicamente mais pobres.

No entanto, para que possamos compreender melhor as demandas de consumo de água e a possibilidade de exploração destas demandas pela iniciativa privada, procuramos discutir a seguir alguns aspectos da relação entre disponibilidade e o consumo de água mundial.

Figuram entre os países com abundância de suprimento de água situados nas áreas intertropicais: Brasil, Uruguai, Paraguai, Bolívia, Chile, Peru, Equador, Colômbia, Venezuela, Guiana, Suriname, Panamá, Costa Rica, Nicarágua, Honduras, Gabão, Congo, Camarões, República Centro-Africana, República Democrática do Congo, Angola, Mianmar, Laos, Malásia, Cingapura, Brunei, Papua Nova Guiné, Austrália, Ilhas Salomão e Nova Zelândia. A água destes países está em grande parte disponível para consumo já que se encontra predominantemente na superfície ou no subsolo.

Países como o Canadá, Irlanda, Noruega, Suécia, Finlândia, Mongólia e Rússia, também possuem água doce em abundância, porém, grande parte de suas reservas encontra-se sob a forma de gelo.

Por outro lado, em zonas áridas ou semi-áridas do planeta a oferta de água doce é limitada, o que leva seus habitantes a uma situação de dependência de fontes externas ou de fontes que são de domínio privado.

Esta distribuição física da água de modo desigual tem acarretado historicamente inúmeros conflitos entre os territórios envolvidos, como lembra Clarke e King (2005, p.75). Deste modo, pode ser citado o caso do conflito entre Israel, Jordânia e Síria desde 1950 sobre a distribuição da água dos escassos cursos d’água da região. Mas, não somente a escassez advinda da distribuição física da água no planeta é sentida, como também a escassez advinda do aumento das demandas, que por sua vez, são traduzidas em três finalidades básicas: o uso doméstico, o uso industrial e o uso agrícola. Estas diferentes demandas também são conflitantes, pois, o aumento de uma implica na redução de oferta de água para outra, no que diz respeito à mesma fonte hídrica, já que a produção de água é constante.

Clarke e King (2005, p.75) ainda resgatam fatos extremos de conflitos entre países com o uso de estratégias de destruição de reservas de água como forma de destruição econômica e de possíveis resistências à submissão, a exemplo do caso de 
destruição “da capacidade de dessalinização do Kuwait” pelo Iraque na Guerra do Golfo entre 1990-1991.

Mesmo sendo essencial à vida, muitas vezes a água é comprometida para se buscar a derrota do inimigo. Deste modo, é comum a história destes conflitos conterem fatos como o rompimento de diques, o bombardeio de represas, bem como a destruição da capacidade de dessalinização e envenenamento das águas.

É importante ressaltar que os conflitos não ocorrem somente em territórios onde há grande escassez de água ou entre aqueles enquadrados quanto à "insuficiência hídrica”. À medida que as demandas por água crescem, diminuem os estoques. Portanto, a abundância de água é relativa, já que grandes áreas produtoras podem ter seus estoques totalmente comprometidos devido ao aumento de suas demandas de consumo e devido à poluição, como chama atenção Tundisi (2003).

Entre as demandas de consumo de água, as demandas domésticas são aquelas relacionadas diretamente ao serviço de saneamento básico, ou seja, o serviço de abastecimento de água, coleta e tratamento de esgotos.

O setor doméstico é o que menos consome água no mundo, e, mesmo assim, há grandes déficits no provimento das necessidades básicas de um grande número de pessoas.

Segundo dados da Organização Mundial da Saúde - OMS ${ }^{8}$, em 2002 cerca de 2,6 bilhões de pessoas não tinham sanitários ou esgoto e 1,1 bilhão não tinha acesso à água potável, o que tem levado à morte cerca de 22.000 pessoas todos os dias, das quais grande número de crianças.

Embasados em preocupações sobre a multiplicação de problemas ambientais que esbarram no aumento desequilibrado do consumo de recursos naturais do planeta, os movimentos ambientalistas têm promovido discussões e o estabelecimento de metas para o alcance do equilíbrio. Estas metas, contudo mostram-se difíceis de serem alcançadas já que os investimentos necessários no setor de saneamento básico não têm sido priorizados por parte das agências multilaterais e por parte dos governos locais.

Segundo informações da Organização para Cooperação e Desenvolvimento Econômico - OCDE, entre 1997 e 2002 houve uma diminuição de investimentos de U\$ 2,7 bilhões para U\$ 1,4 bilhão em saneamento básico, estabilizando-se neste patamar a

\footnotetext{
${ }^{8}$ Organização Mundial da Saúde - OMS. Regional and global drinking water and sanitation coverage estimates. 2002. Disponível em:

< http://www.who.int/water_sanitation_health/monitoring/jmp2005.annexes.pdf > Acesso em jan/2006.
} 
partir de 2002, o que denota um provável aumento dos déficits, já que as demandas são crescentes.

Enquanto o setor de saneamento básico apresenta um quadro de estabilização ou mesmo de retração nos investimentos, o setor agrícola vem apresentando índices crescentes de consumo de água.

São extensas as áreas agrícolas irrigadas hoje no planeta, consumindo cerca de 70\% da água doce disponível. Porém, não devemos deixar de considerar que o retorno da água ao seu ciclo hidrológico no setor agrícola é mais rápido do que nos demais setores, já que a água infiltra imediatamente no solo contribuindo para alimentar os lençóis freáticos ou evapora e alimentará outras áreas por meio das chuvas.

Também como já se discutiu a água é intensamente utilizada em várias etapas dos processos produtivos industriais. A indústria é a segunda maior consumidora de água do planeta, principalmente por parte de países como o Canadá, EUA, França, Bélgica e Bulgária.

Apesar de a agricultura consumir a maior quantidade de água, o maior valor agregado está no produto industrial. Segundo Clarke e King (2005, p.39) “Uma tonelada de água utilizada na indústria gera um rendimento 70 vezes mais valioso do que 1 tonelada de água usada na agricultura”. Deste modo, é possível inferir que os países industrializados não só não deixarão de produzir, como se espera o aumento da demanda de consumo de água por parte de novos centros industriais.

Projetando esta situação os autores exemplificam com o caso dos Estados Unidos que apresentam uma redução da oferta de água doce disponível por pessoa, por ano. Em 1955 foram contabilizados 14,934 m³/pessoa/ano, em 1990 esta oferta diminuiu para 9,913 m³/pessoa/ano e em 2055 está prevista uma redução na oferta para 7,695m³/pessoa/ano. Deste modo, entre 1955 e 1990 houve uma redução de 33,6\% na oferta e entre 1990 e 2055 há uma previsão de redução de 22,4\%. Nota-se que a redução da oferta de água doce foi menor para o período mais recente, considerando-se uma projeção otimista que pode representar uma diminuição no consumo.

Porém, os dados disponíveis da Food and Agriculture Organization - FAO mostram que há uma crescente exploração de água, que pode alterar a posição privilegiada deste país no campo econômico mundial, ou talvez induzir a criação de novas estratégias que envolvam o uso da água. 
Notadamente para que os países industrializados possam manter suas produções no ritmo atual ou mesmo ampliá-las devem ser consideradas algumas alternativas para a garantia de suprimento.

A primeira alternativa envolve investimentos em importação de água, ou seja, esta opção baseia-se no abastecimento a partir de fontes externas, tal como já é efetuado por alguns estados do noroeste dos Estados Unidos da América em negociação com o Canadá e entre a Turquia e Israel. Neste tipo de alternativa não há mudanças estruturais quanto à reavaliação no consumo interno de água, há ao contrário, até possibilidade de expansão do consumo. A opção pelo uso de fontes externas passa a abranger outras áreas e, pode resultar em conflitos futuros, que podem ocorrer em qualquer escala. Para o caso brasileiro pode-se citar o exemplo recente de conflito em relação a exportação de água da Bacia do Piracicaba para a Região Metropolitana de São Paulo.

Não pode ser esquecido neste último exemplo, que a opção por importação de água da Bacia do Piracicaba por parte da Companhia de Saneamento Básico do Estado de São Paulo - Sabesp ocorreu em um contexto de desenvolvimento econômico que difere da atual realidade.

No início do processo de exportação de água, por meio do Sistema Cantareira, as cidades pertencentes à Região de Campinas não eram grandes consumidoras e, portanto, a exportação de água para a Região Metropolitana de São Paulo não era problemática. Porém, com o crescimento e dinamização econômica e industrial da região de Campinas e aumento das demandas nesta região a água passou a se tornar escassa, implicando em grande entrave ao seu desenvolvimento. Isto resultou em conflito que exigiu negociação envolvendo a Sabesp, representantes do Comitê da Bacia do Rio Piracicaba, Capivari e Jundiaí e Agência Nacional de Águas - ANA, em agosto e 2004.

A segunda alternativa envolve a modificação tecnológica e adoção de equipamentos mais econômicos no consumo de água, como já vem sendo efetuado por muitos produtores rurais de vários países. Como exemplo disto é possível citar as tecnologias de irrigação por gotejamento em substituição àquelas que usam água em abundância. Esta alternativa é esperada por envolver a modificação no padrão de consumo, possibilitando sua diminuição, mas ainda esbarra no acesso, especialmente por parte de pequenos produtores rurais. 
A terceira alternativa envolve a criação de um mercado para a água e sua valorização por meio do aumento de seu preço. Os defensores desta alternativa acreditam que os altos preços induziriam à economia no consumo.

Outras possibilidades também foram observadas por Raffestin (1993, p.253) tais como da intensificação de exploração das reservas, elaboração de acordos bilaterais entre possíveis fornecedores e entre outros usuários.

É interessante notar, como observa Raffestin (1993) que estas alternativas ou “possibilidades” não são importantes somente como formas de possibilitar o consumo ou evitar conflitos, mas podem ser utilizadas pelos atores envolvidos como forma de escape da trama de pressões criadas pela idéia de raridade de uma determinada matéria.

Para o autor a idéia de raridade é utilizada como instrumento de manipulação para que determinado "recurso" se transforme em arma econômica.

Neste sentido, ao pensarmos no caso da água, o avanço da idéia de escassez, tem se mostrado como uma das maiores preocupações da atualidade, apesar desta escassez ser relativa em grande parte dos países do mundo.

Ainda, chama a atenção o fato de que entre as várias alternativas possíveis para a tentativa de solução da problemática de escassez da água, aquela fortemente apontada como favorita é a de cunho econômico.

A tese de que o mercado funcionaria como regulador e seria capaz de gerar uma maior conscientização sobre o valor da água e a conseqüente transformação nos padrões de consumo mundial, impulsionando a redução da demanda é adequada para encobrir as contradições existentes e o jogo de interesses envolvidos.

Estas contradições e o jogo de interesses ficam mais claros ao examinarmos a atuação de grandes corporações transnacionais no mercado mundial da água, já que é a raridade da água enquanto recurso que alimenta a expectativa de expansão dos domínios de atuação destas corporações e de seu valor no mercado.

A idéia de escassez merece, pois, um maior aprofundamento em sua reflexão e, para tanto procuraremos enfocá-la a seguir.

\section{A escassez como estratégia de acumulação}


Como já foi abordado, o desenvolvimento científico e tecnológico, a exemplo do uso de imagens de satélite, computadores e aparelhos de aferição modernos, podem contribuir para o estabelecimento preciso das fontes de água, indicando sua distribuição, seus volumes e, até certo ponto, seu estado de conservação. Contudo, não há controle sobre o seu consumo e sobre o comprometimento qualitativo em grandes parcelas do território mundial.

Em relação às águas subterrâneas no caso brasileiro, ainda há grande incerteza em relação à aferição do consumo, já que ainda se verifica a ausência de controle e de regulamentação do uso de águas subterrâneas. Deste modo, os poços perfurados são estimados, sendo que "não há cadastro oficial, nem monitoramento de qualquer destes poços”, conforme expôs o chefe da divisão de hidrologia e exploração da Companhia de Pesquisas de Recursos Minerais - CPRM, em 1998, à Caride (1998, p.6) em entrevista ao jornal Gazeta Mercantil.

Mais do que domínio tecnológico, nota-se verdadeira carência de instrumentos de gestão adequados à realidade prática dos organismos competentes no que concerne, principalmente, ao controle da outorga, à fiscalização e ao monitoramento do uso dos recursos hídricos.

O sucateamento de organismos públicos encarregados da gestão dos serviços de saneamento básico tem ocorrido em diversos aspectos, entre os quais se destacam a diminuição dos quadros de pessoal e o arrocho salarial, contribuindo para a desvalorização do trabalho no setor e para a queda na produtividade dos serviços.

É possível, neste sentido, ilustrar o processo de sucateamento da Companhia de Saneamento da Amazônia - Cosama -, que foi substituída pela empresa “Águas do Amazonas” em Manaus.

Para tanto, devemos observar a seguir o gráfico elaborado com base nos dados do SNIS, que aponta a evolução de alguns índices do saneamento básico em Manaus entre o período anterior à concessão dos serviços à iniciativa privada (entre 1995 e 2000) e o período após a concessão. Estes índices tratam da quantidade de pessoal empregado e produtividade por pessoal próprio antes da concessão e após a concessão.

É possível observar que há relação entre o índice de produtividade do pessoal próprio da empresa prestadora de serviços de saneamento básico em Manaus e a quantidade de empregados entre 1995 e 1999. 
Quando houve aumento do número de empregados a produtividade acompanhou este crescimento e quando houve diminuição do número de empregados a produtividade diminuiu. Embora em 2000, os dados tenham apontado uma quebra nesta tendência, com diminuição de empregos e aumento da produtividade, este caso foi isolado.

Nota-se que para os anos seguintes, com a manutenção de baixos índices de empregados próprios, a produtividade também caiu. Ainda, deve ser ressaltado que o ano 2000, em Manaus, foi marcado pela concessão dos serviços de saneamento básico à iniciativa privada. Neste sentido, indicar o crescimento da produtividade, mesmo com grandes cortes no número de empregados, poderia ser parte da estratégia de atração ao capital internacional.

\section{Gráfico 1}

\section{Manaus - Índice de Produtividade em função da quantidade de empregados em saneamento básico entre 1995 e 2004}

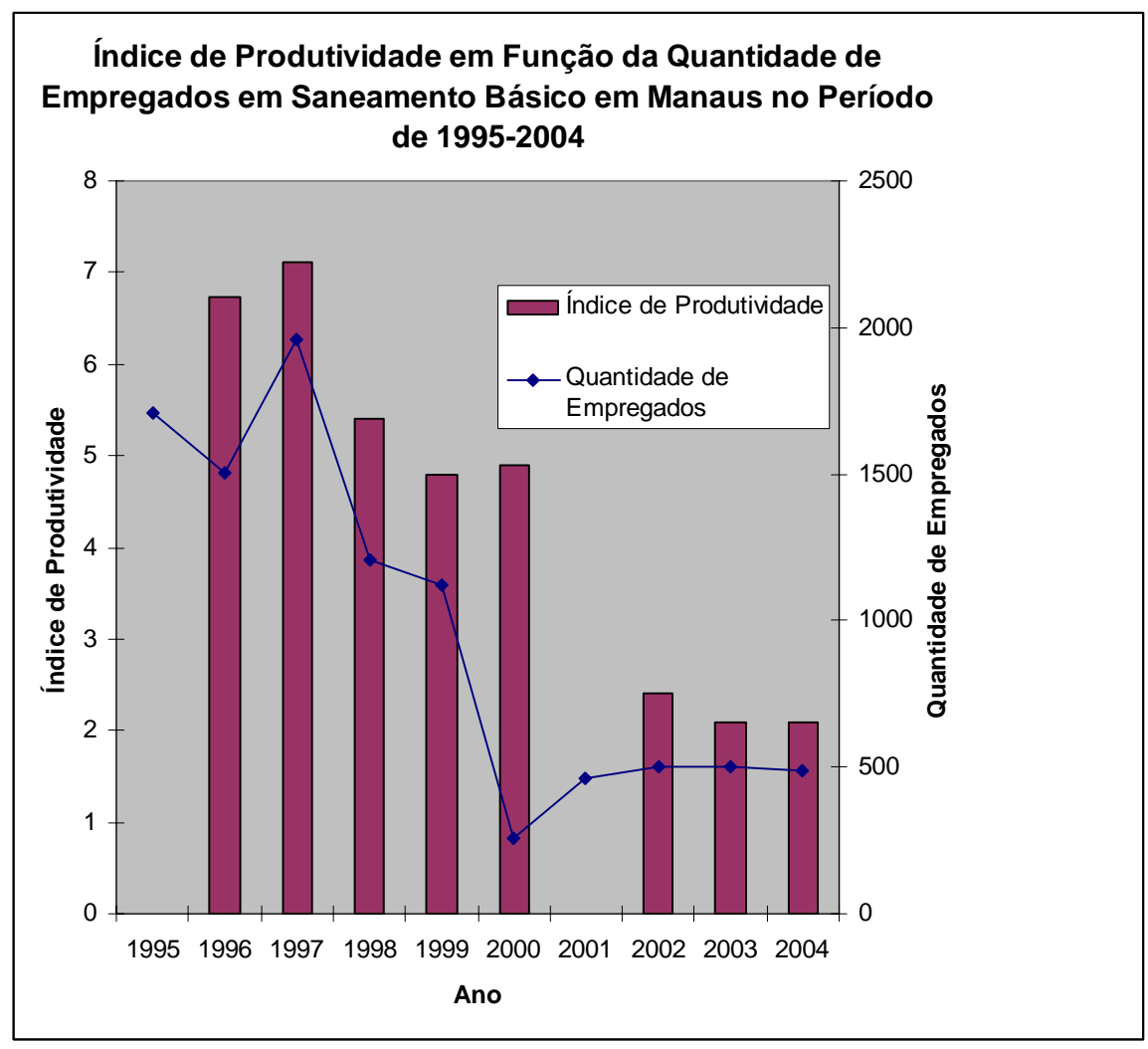

Fonte: SNIS - Diagnósticos anuais / Organização: Cristiane F. de Oliveira

Para o caso de Limeira, também houve drástica redução de funcionários e, de acordo com Justo (2004) também foi verificado processo de desvalorização salarial. 
Deve ser ressaltado ainda, que em 2000 foram demitidos cerca de $70 \%$ dos empregados próprios da antiga Cosama, em Manaus, constando nos dados do SNIS que a margem de despesa com pessoal próprio para este mesmo ano teria chegado a 220,5\%, contra uma média de $47,6 \%$ para os anos anteriores. Isto indica que o ônus das indenizações teria ficado a cargo da companhia privatizada - empresa pública estatal, o que sugere fragilidades internas quanto à defesa dos interesses públicos por parte das instâncias de gestão envolvidas no processo de negociação da concessão.

Sob este aspecto, pode-se afirmar que também em Limeira o processo de concessão dos serviços de saneamento básico à iniciativa privada, como ressalta Justo (2004), também onerou o poder público municipal. Este ônus teria se configurado em vários aspectos, dentre os quais os principais seriam aqueles concernentes às obrigações contratuais lavradas entre as partes envolvidas (Prefeitura e empresa concessionária).

Entre algumas das obrigações relatadas por Justo (2004) consta a obrigação da Prefeitura de Limeira em arcar com os custos e indenizações derivadas de desapropriações necessárias à execução de obras e serviços. Também, a assunção das dívidas com as indústrias que formaram parcerias de investimentos em saneamento básico no passado e a ausência de definição quanto aos bens passíveis de reversão no final da concessão foram itens que beneficiaram a empresa concessionária, principalmente nos primeiros anos de atuação. Além disso, como menciona Justo (2004), a Prefeitura Municipal de Limeira teria antecipado investimentos os quais a concessionária absorveu em suas metas de investimentos contratuais.

Vargas e Lima (2004) lembram ainda que a Prefeitura Municipal de Limeira também assumiu o passivo trabalhista do antigo Serviço Autônomo de Água e Esgoto SAAE -, tal como ocorreu no caso do governo do Amazonas, na concessão da Cosama em Manaus.

Em ambos os casos a participação das instituições políticas na defesa de interesses privados, nos processos de concessão dos serviços, pôde ser sentida na elaboração de contratos com mínimos riscos para as empresas concessionárias e na assunção de encargos por parte das instâncias públicas, o que implica na transferência do custo destes encargos para a sociedade. Por si só este fato pode ser considerados não somente como parte do sucateamento das empresas concedidas, mas também como do próprio Estado. 
Segundo Tabb (1997, p.28), essas frágeis estruturas políticas e sociais acabam por reforçar a idéia de que o Estado não tem poder para frear esse movimento exploratório, o que por sua vez, passa a ser uma “poderosa ferramenta do próprio capital”, encerrando um círculo vicioso em que a exploração geraria mais fragilidades e, mais dependência.

Essa debilitação, por sua vez, não é fruto somente de oscilações na economia e de capacidade de investimentos públicos, mas também é resultado de luta dos interesses econômicos particulares em busca da apropriação privada dos recursos públicos. Deste modo, a falha do sistema público pode proporcionar lucro àquele que ou aproveita “brechas” no sistema ou as constrói.

No que concerne aos investimentos públicos em saneamento básico, também é possível notar que o ano 2000 é um marco em diminuição de investimentos, para o caso de Manaus, como pode ser observado no gráfico a seguir.

Entre 1995 e 1997 foi possível verificar pelos dados do SNIS que houve um crescimento dos investimentos em abastecimento de água, chegando a seu pico de investimentos (1997) a cerca de R\$ 38 milhões. Em 1998, apesar de haver um decréscimo no investimento, o valor investido ainda foi alto chegando a R 32 milhões. Porém, em 1999, um ano antes da concessão houve diminuição de cerca de 80\% nos investimentos em abastecimento de água, sendo que no ano da concessão, em 2000, os investimentos foram reduzidos ainda mais, chegando ao menor valor declarado de investimento, ou seja, R\$ 302.272,00.

Quanto aos investimentos em esgotos, nota-se uma maior oscilação, porém, também o ano de 1997 representou um grande crescimento em investimentos, chegando a R\$ 6.377.849,00.

Deve-se observar que após a concessão em Manaus os investimentos privados foram mantidos muito abaixo dos investimentos públicos nos anos anteriores à concessão, tanto em abastecimento de água como esgotamento sanitário. Os baixos investimentos em esgotamento sanitários, por sua vez, contribuem ainda mais para a implementação da escassez qualitativa de água e para o encarecimento do tratamento da água para fins de abastecimento. 


\section{Gráfico 2}

Manaus. Investimentos em água e esgotos entre 1995 e 2004

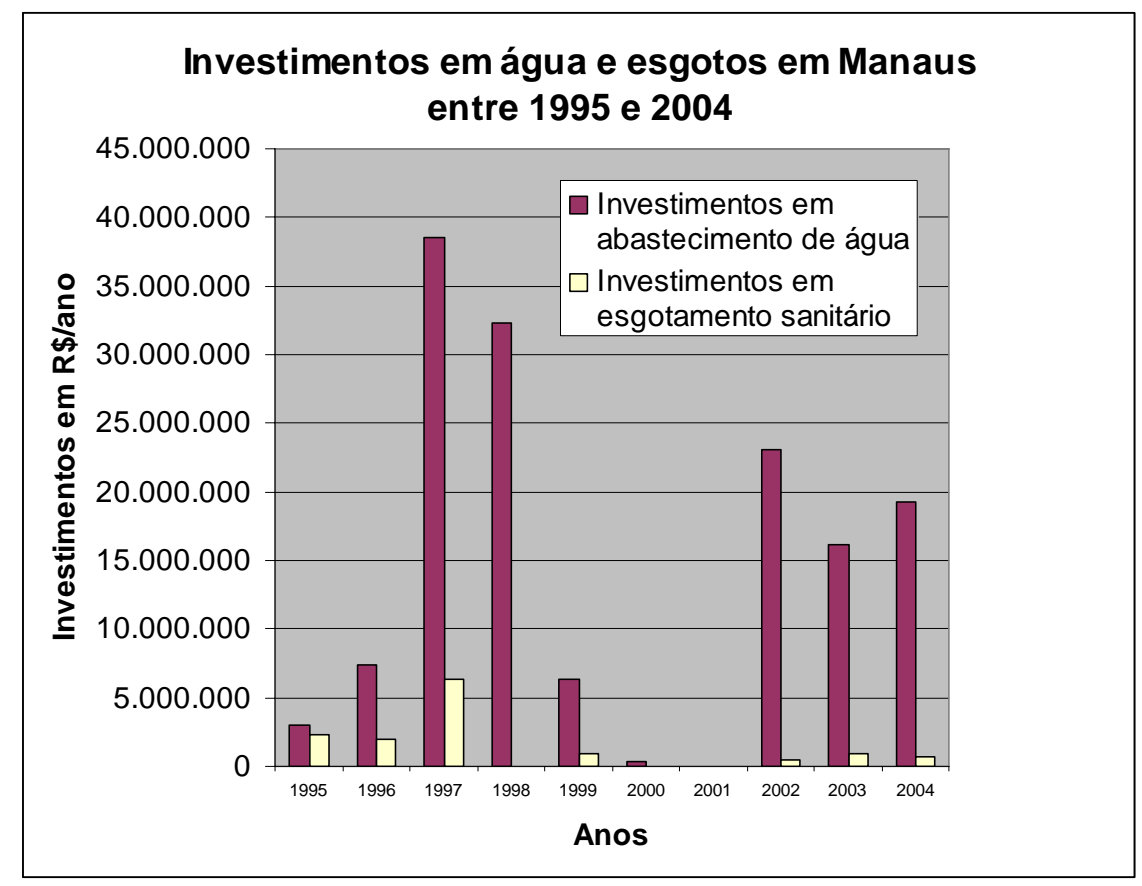

Fonte: SNIS - Diagnóstico anual / Organização: Cristiane F. de Oliveira

Nota-se que entre 2001 e 2004 a empresa “Águas do Amazonas” investiu em esgotamento sanitário R\$ 2.053.718,00 contra R 11.514.574,00 investidos entre 1995 e 2000 pelo poder público estadual.

Se no âmbito local, para o caso de Manaus, nota-se drástica redução de investimentos e de empregos no setor de saneamento, no âmbito internacional, o discurso da ampliação da escassez de água e os riscos de saúde pública associados à ausência de saneamento básico trás à tona a necessidade de ampliação do acesso à água e de controle sobre seu consumo perdulário. Neste sentido, seguindo a lógica desta preocupação, deveriam ser proporcionados maiores investimentos no setor que poderia refletir em possível incremento no quadro de pessoal responsável pela manutenção e operação dos sistemas. Porém, o discurso do aumento da escassez também tem contribuído para que organismos internacionais, como o Fundo Monetário Internacional e o Banco Mundial pressionem os governos de países dependentes a optarem pela via privada de operação de seus serviços de saneamento básico. Contudo, o caminho da concessão privada dos serviços de saneamento básico nem sempre permite a universalização do acesso ou maiores investimentos no setor. 
É neste contexto que o estudo dos casos de concessão privada em Manaus e em Limeira pode nos auxiliar a avaliar as conseqüências para a sociedade diretamente envolvida e, em última instância, também avaliar o alcance das metas internacionais relacionadas à gestão da água. Em tese estas metas internacionais buscam solucionar os problemas relacionados aos déficits de saneamento básico para grande parte da população mundial e minimizar os riscos futuros de escassez.

Posta a questão sobre a apropriação do tema da escassez de água pelo discurso de cunho econômico, que procura fundamentar a mobilização de uma corrente próprivatização dos serviços, é necessário desvendar as reais situações em que se configura a escassez.

Tratar o tema da escassez, entretanto, não é tarefa simples. Há a chamada escassez quantitativa e a escassez qualitativa. A primeira pode ser parcialmente dimensionada pelo cruzamento dos fatores que influenciam as vazões produzidas, como clima, o uso do solo. Porém, as demandas não são facilmente controláveis ou sequer precisamente reconhecidas.

No que se refere à escassez qualitativa, também as informações são bastante imprecisas, em parte devido à deficiência de fiscalização quanto às fontes difusas de poluição e conseqüente comprometimento da água.

Mas, se há grande dificuldade ou mesmo ineficiência quanto ao controle sobre o consumo e também sobre as fontes poluidoras, como estabelecer com precisão os limites entre a oferta ou a escassez da água doce?

Os indicadores que embasam a definição de escassez estão apoiados no aumento das demandas mundiais e na deterioração da oferta. Por sua vez, o aumento das demandas não está relacionado simplesmente ao crescimento das populações em termos absolutos, mas à sua concentração e ampliação de seu uso em várias etapas da estrutura produtiva criando necessidades acima da capacidade de atendimento das vazões naturais dos sistemas hídricos locais.

As demandas por abastecimento de água e por coleta e tratamento de esgotos se intensificaram com crescimento das cidades e com o processo de desenvolvimento industrial, como lembra Silva (1999). Contudo, esta intensificação nem sempre foi acompanhada de oferta, seja por impossibilidade de atendimento das demandas por ausência de água, seja por incapacidade econômica de investimentos em infra-estrutura.

Ainda outra questão chama a atenção: Para quem há escassez de água doce? 
Poderíamos dizer simplesmente que a escassez está associada à pobreza econômica, mas esta questão exige uma reflexão mais aprofundada.

Segundo informações do Fundo das Nações Unidas para a Infância - Unicef ${ }^{9}$, a maior parte dos países do mundo, ou seja, 57\% apresentam mais da metade de suas populações concentradas nas cidades. Somente 6,5\% dos países apresentam tendências de decréscimo populacional para as áreas urbanas, o que nos leva a considerar as previsões de aumento das demandas de consumo de água nas áreas urbanas.

Em relação a isto, podemos iniciar uma reflexão sobre a segunda questão, ou seja, para quem há escassez?

A escassez de água é sentida por aqueles cujo acesso é dificultado pelas características físicas locais, mas também e, principalmente, por aqueles cujo acesso é dificultado pelas características sócio-econômicas impostas. Neste sentido, há escassez para aqueles indivíduos que sobrevivem em situações constantes de adversidade natural, ou seja, em regiões desérticas ou semi-desérticas, cujo clima não favorece a oferta abundante de água e, há escassez para aqueles indivíduos cuja pobreza econômica impossibilita o custeio dos serviços de saneamento básico, ou seja, de abastecimento, coleta e tratamento de esgotos, impostos pela condição urbana.

Sobre esta mesma fonte de dados é possível inferir que somente cerca de 30\% dos países possuem fonte de água tratada para mais de 90\% de sua população. Entre os países que ainda não alcançaram estes índices chamam a atenção, principalmente, aqueles com grandes populações, como a China que possui oferta de abastecimento a 75\% de uma população de cerca de 1 bilhão de habitantes, o que significa a exclusão de 321 milhões de habitantes. Outro exemplo escandaloso é o da Índia que possui cerca de 1 bilhão de habitantes, excluindo do acesso à água 161 milhões de habitantes, ou seja, um número de habitantes superior à população brasileira.

Os índices de acesso à água tratada para o caso brasileiro são de $87 \%$ e, neste contexto ficam de fora cerca de 22 milhões de pessoas.

Deve-se esclarecer que a “fonte de água tratada” refere-se à água acessada via redes de abastecimento, que estão concentradas principalmente nas áreas urbanas existentes. Neste sentido, estes índices apresentados, apesar de proporcionar um panorama geral da situação do acesso ao abastecimento no que concerne às áreas urbanas, não definem a situação das áreas rurais e da população do campo. Estas

\footnotetext{
${ }^{9}$ Fonte de dados a partir do Indicador do Milênio da Organização das Nações Unidas - ONU (Divisão Populacional) e Unicef para o ano 2000.
} 
populações rurais, especialmente aquelas economicamente mais pobres ficam totalmente expostas aos riscos de exclusão ao acesso à água, já que nas situações de estiagens prolongadas, as únicas fontes de água desaparecem, resultando em intenso fluxo migratório e em altos índices de mortalidade, principalmente a infantil. Isto significa que além dos 22 milhões de brasileiros excluídos do acesso à água tratada em redes, moradores de áreas urbanas, também devem ser acrescentados aqueles excluídos do acesso à água por residirem em áreas rurais, onde predominam os climas secos e que não possuem recursos econômicos para obtê-la, como ocorre em vários municípios do interior da região semi-árida brasileira.

Nas áreas urbanas a impossibilidade de conseguir fontes alternativas à prestação de serviços de saneamento é cada vez menor. O tamanho pequeno dos lotes urbanos, o alto grau de contaminação dos aqüíferos subterrâneos e o alto custo da exploração por poços profundos têm inviabilizado a exploração individual por parte de populações mais pobres.

Uma das poucas alternativas ainda utilizadas, apesar de sua utilização esporádica, é a compra de água "avulsa” e isto tem gerado grandes rendimentos para certo número de empresas que dominam o mercado, principalmente àquelas que comercializam água “mineral”. Deste modo a venda de água bruta é oferecida por empresas de entrega (em caminhões pipa), ou a venda de água tratada é efetuada por meio de entrega em galões ou em garrafas.

Neste sentido, devido ao grande número de habitantes nas áreas urbanas que dependem dos serviços de saneamento para obter acesso à água, é que se tornam urgentes as ações que possam avaliar de forma aprofundada o atendimento das demandas. A urgência do atendimento das aglomerações urbanas está relacionada à viabilização da salubridade e, portanto, da perpetuação da vida nas cidades. Desta forma são cada vez mais necessários estudos que possam avaliar a situação do saneamento básico nestas áreas e auxiliar a viabilização de propostas que possam reduzir o grau de escassez de água que atinge ou atingirá estas populações.

Os maiores atingidos pela escassez de água nas cidades são as populações mais empobrecidas, que ocupam as margens do tecido urbano, nas chamadas pontas de rede. Nestes locais, a população embora muitas vezes próxima das áreas de mananciais, está situada nas pontas da rede de distribuição, onde o sistema de bombeamento de água é enfraquecido, sendo comum a intermitência na distribuição de água, quando esta existe. 
Sob o aspecto do risco de escassez relacionado ao setor agrícola pode-se inferir que os sistemas de produção adotados e a concentração de terras influenciam no consumo e no acesso à água.

Em relação à agricultura nota-se que no caso brasileiro, ainda dominam as monoculturas, baseadas em sistemas extensivos de produção em grandes latifúndios, que pode ser traduzido principalmente pela produção de soja, cana-de-açúcar, pastoreio e silvicultura.

Sobre esta concentração de terras há duas questões que chamam a atenção de imediato e que estão diretamente relacionadas ao acesso e consumo de água: a indução da exclusão de grande número de pessoas ao acesso da água, pelo afastamento de suas fontes disponíveis e, pela ausência ou falha no controle sobre o consumo de água por parte destes latifúndios.

Esses grandes latifúndios têm induzido historicamente o êxodo rural e o aumento das demandas por serviços de abastecimento públicos urbanos, enquanto que suas necessidades de consumo são supridas por meio do uso das reservas de água superficiais e subterrâneas sem qualquer controle ou mensuração por parte das instituições responsáveis pela emissão de outorga de uso.

Apesar do setor agrícola brasileiro não apresentar grande investimento em uso de tecnologia, utilizando-se relativamente pouco de técnicas artificiais de irrigação, deve-se ressaltar que são os períodos de estiagem prolongada que fornecem indícios sobre quais são as regiões e as populações mais afetadas pela escassez.

A escassez de água na agricultura é mais sentida por pequenos produtores e por produtores localizados em zonas áridas ou semi-áridas, que estão impossibilitados economicamente em arcar financeiramente com os custos da obtenção de fontes alternativas de água, como perfuração de água subterrânea ou com os custos envolvidos na utilização de tecnologias de irrigação mais eficientes em economia de água. Mais uma vez, é possível notar o aspecto físico e o sócio-econômico como parâmetros a serem considerados na avaliação das potencialidades de escassez.

Em relação à indústria, como a segunda maior consumidora de água do planeta, pode-se inferir que sua produção depende totalmente da água, havendo grande interesse na manutenção ou mesmo na ampliação da oferta. Nota-se que apesar dos grandes volumes consumidos por parte deste setor e pelo grande impacto de suas atividades 
sobre a qualidade das águas, não houve ainda alterações significativas quanto ao seu contínuo crescimento ou quanto ao uso efetivo de mecanismos limpos.

Apesar do avanço das discussões sobre a adoção de mecanismos limpos nos processos industriais, como ilustra Kunz et al. (2002), as tecnologias avançadas para melhoria da qualidade de efluentes ou mesmo de redução da quantidade consumida ainda são utilizadas parcialmente por envolverem altos custos de investimentos.

Por outro lado, o desenvolvimento das políticas públicas de gestão dos recursos hídricos, no sentido de desenvolvimento de mecanismos de maior controle e cobrança sobre a qualidade dos efluentes lançados e da busca da melhoria da qualidade ambiental, tem induzido, paulatinamente, à adoção destas chamadas tecnologias limpas. Pode-se deduzir que, com estas ações, a médio e longo prazo haverá possibilidade de diminuição dos impactos da indústria sobre a água.

Mas os dados atuais não são otimistas a este respeito. Segundo Clark e King (2005, p.38) o ritmo de consumo de água pelo setor industrial vem crescendo desde 1950, sendo que entre 1980 e 2000 seu ritmo de crescimento diminuiu. No entanto, a projeção estimada para 2025 prevê forte elevação do consumo de água pela indústria, como podemos observar no gráfico a seguir:

\section{Gráfico 3}

Consumo mundial de água pela indústria $\left(\mathrm{km}^{3}\right)$

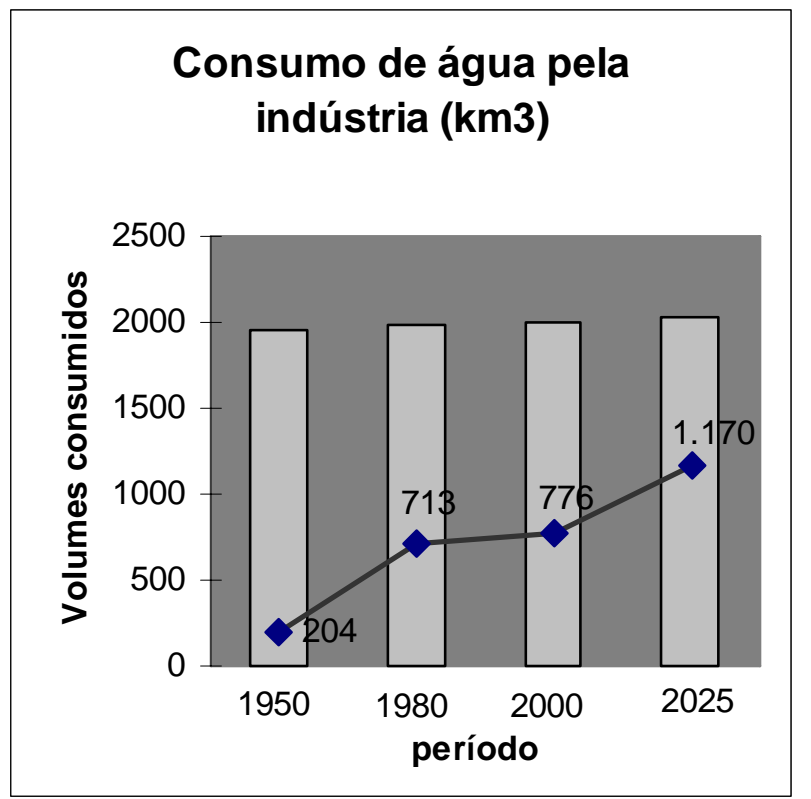

Fonte: CLARKE e KING (2005: p.38) - Água para a indústria 
Não podemos deixar de observar também que o desenvolvimento industrial não ocorre igualmente entre todos os países e mesmo do ponto de vista regional, interno a cada país, há diferenças quanto ao grau de desenvolvimento e quanto aos tipos de indústria instalada, o que reflete em maior ou menor grau de consumo de água.

Ainda, quanto à questão dos diferentes estágios de desenvolvimento industrial, a evolução de técnicas, como a nanotecnologia, pode contribuir para alterar a crescente corrente de consumo em diversos setores. Neste aspecto, quanto mais desenvolvidas tecnologicamente as indústrias estiverem, maior será a produtividade, ou seja, maior produção com menor gasto de recursos naturais, que para este caso de análise se traduz em água.

Ao exemplificar o uso de água frente ao consumo do setor industrial não podemos deixar de citar o caso dos EUA, que apresenta, segundo a $\mathrm{FAO}^{10}$, um aumento do consumo significante ao compararmos dados de dois períodos: entre 1988-1992 e 1998-2002. Para o primeiro período foi apresentado um consumo de água de 781,6 $\mathrm{m}^{3} \mathrm{p}$ /pessoa/ano e para o segundo período foi apresentado um consumo de água de 1.647 $\mathrm{m}^{3}$ /pessoa/ano, o que indica um crescimento do consumo de $110 \%$.

Além dos EUA, segundo a FAO/Aquastat, também constam entre os países maiores consumidores de água para abastecimento industrial, considerando um consumo acima de $500 \mathrm{~m}^{3}$ por pessoa em 2000, o Azerbaijão, a Bélgica (incluindo dados de Luxemburgo), a Bulgária, o Canadá, e a França.

É possível avançar nesta análise se avaliarmos a situação de produção ${ }^{11}$ de água destes países. De acordo com a FAO estes países citados não possuem o mesmo padrão de produção de água.

Como pode ser observado no gráfico a seguir, nem sempre o consumo de água respeita a produção de recursos hídricos interna de cada país.

\footnotetext{
10 FAO - Food and Agriculture Organization - Aquastat. Disponível em: <.In: www.fao.org/ag/agl/aglw/aquastat/ > Acesso em Abril/2005

${ }^{11} \mathrm{O}$ termo produção de água tem sido comumente utilizado para designar volumes de água aduzidos e tratados ou somente aduzidos. Como os dados informados não especificam se houve adução e tratamento, adotamos esse termo genérico, com a ressalva de que a água não pode ser produzida, mas, coletada e beneficiada.
} 


\section{Gráfico 4 \\ Produção e consumo de água em países com destacado consumo para fim industrial - 2000}

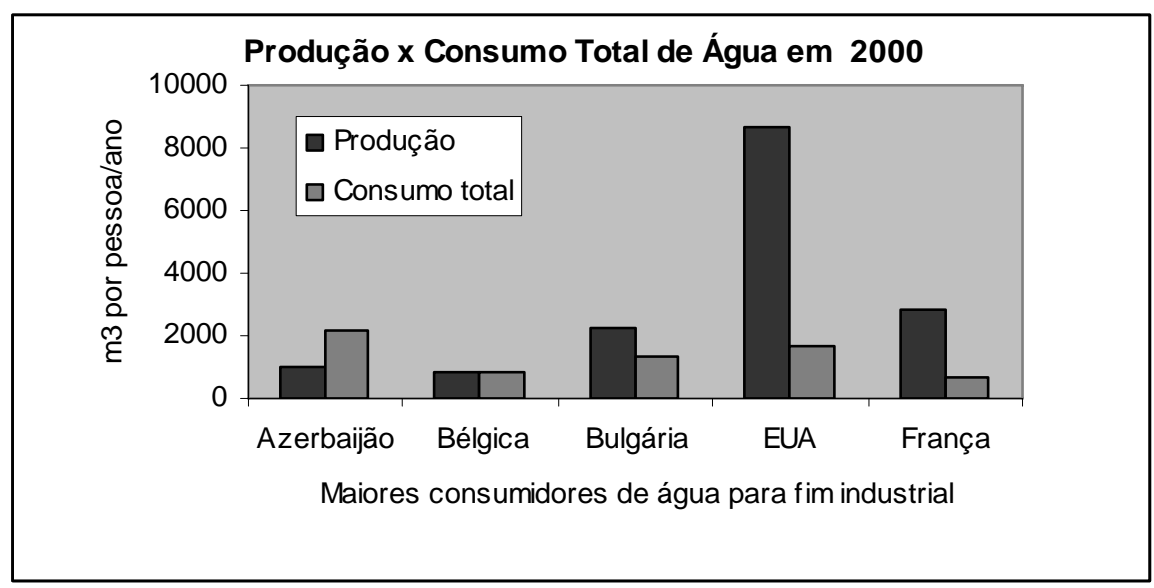

Fonte: FAO/Aquastat e Robin Clarke e Jannet King (2005) / Organização: Cristiane F.Oliveira

O Canadá também pode ser incluído nesta lista com uma produção de água de $92.646 \mathrm{~m}^{3} /$ pessoa/ano (em 2000) e um consumo de $1.494 \mathrm{~m}^{3} /$ pessoa/ano (2000), dos quais 69\% são para fim industrial.

No gráfico anterior pode-se observar que para o caso do Azerbaijão há maior consumo total de água do que produção, o que leva esse país a depender fortemente de fontes hídricas externas. Bem como o Azerbaijão, a Bélgica também já depende em cerca de 34\% de água advinda de fontes externas e seu consumo interno está praticamente empatado com sua capacidade produtiva.

A Bulgária por sua vez chama atenção por seu alto índice de consumo (1.321 $\mathrm{m}^{3}$ /pessoa/ano), quase se igualando ao índice de consumo total de água dos EUA (1.692 $\mathrm{m}^{3}$ /pessoa/ano) e ultrapassando-o em relação ao índice de consumo de água para fim industrial para o ano 2000, como veremos a seguir no gráfico 5. Para o caso da França e dos EUA a produção atual atende as necessidades de consumo. Contudo, é importante notar no gráfico a seguir que a produção projetada para ambos os países em 2050 é menor do que a atual enquanto que seu crescimento industrial e consequentemente suas demandas por água são notadamente crescentes. 
Gráfico 5

Produção de água em 2000 e projeção para 2050 em países com grande destaque no consumo de água para fim industrial

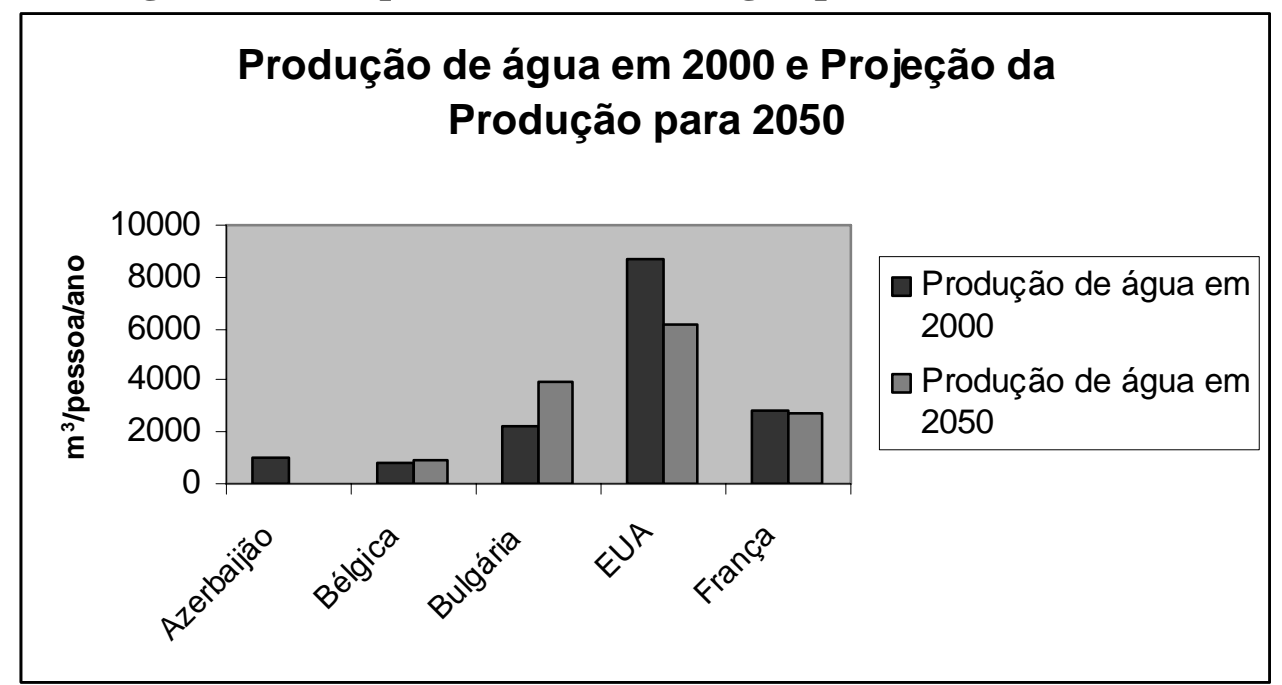

Fonte: FAO/Aquastat e Robin Clarke e Jannet King (2005). Organização: Cristiane F.Oliveira

Apesar de todos os países citados, incluindo o Canadá apresentarem grandes volumes de água destinados à indústria, nem todos apresentam este setor como o que mais consome água no país, a exemplo do Azerbaijão e dos EUA que apresentam grandes volumes de água destinados à indústria, mas volumes ainda maiores destinados à agricultura. Para os demais, contudo, os grandes volumes apresentados representam o domínio do consumo de água pelo setor industrial, conforme pode ser apreciado no gráfico a seguir.

Entre os países supracitados a Bélgica não apresenta uma grande produção de água, mas mesmo assim consome grande parte de sua produção no setor industrial. Ainda, deve ser considerado que o total de água explorada por este país para o período de $1998-2002$ foi de $835,9 \mathrm{~m}^{3} /$ pessoa/ano, o que implicou no uso total de suas reservas superficiais e também subterrâneas. Portanto, dentro deste contexto, o incremento de 7\% em sua produção para o ano 2050 provavelmente não possibilitará a cobertura dos déficits. 
Gráfico 6

Países com destacado consumo de água para fim industrial. Participação do consumo de água para fim industrial frente às demandas agrícolas e domésticas

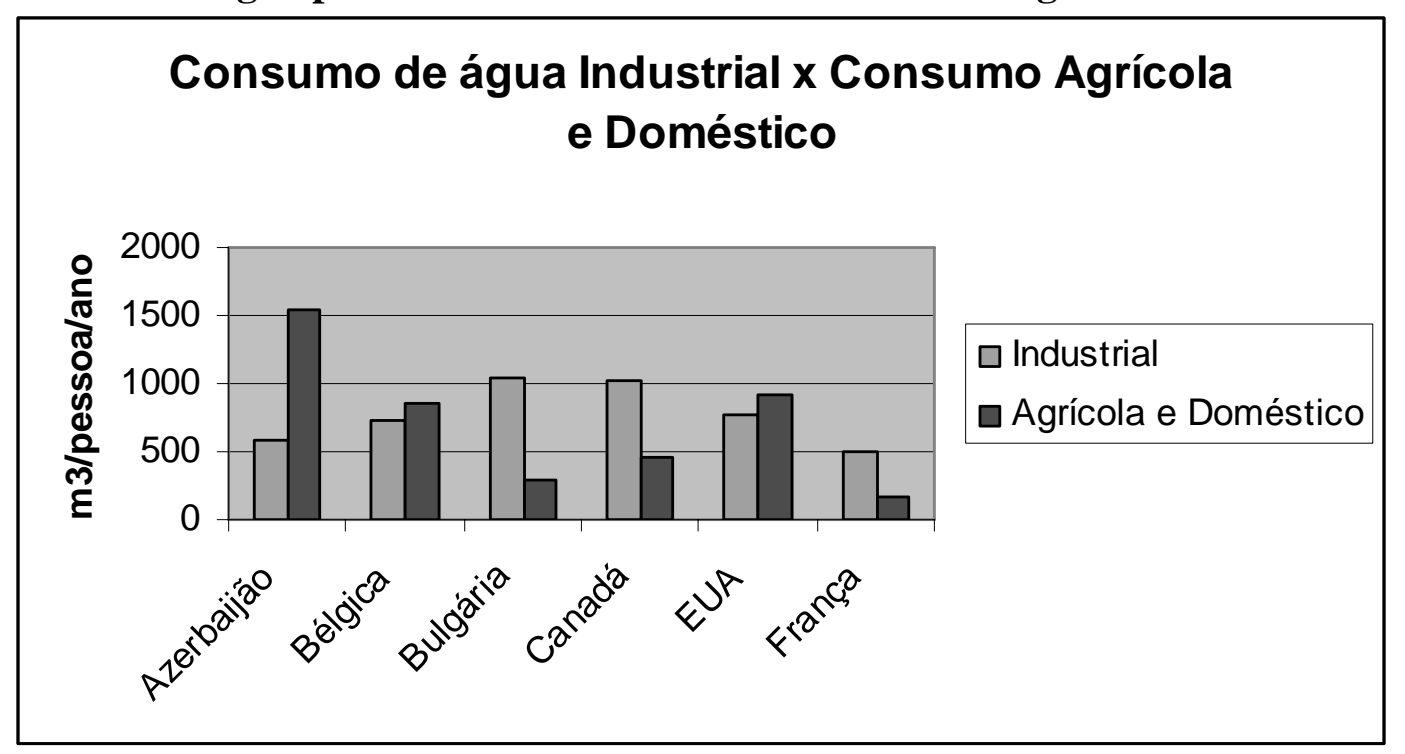

Fonte: FAO/Aquastat e Robin Clarke e Jannet King (2005) Organização: Cristiane F. de Oliveira

A previsão para a França demonstra praticamente uma estabilização de sua produção de água, com redução de apenas 4,4\%. O total do consumo de água na França sobre o total de água produzido para o ano 2000 foi de cerca de $20 \%$, ou seja, de 667,7 $\mathrm{m}^{3}$ /pessoa/ano.

O Canadá, a Bulgária e os EUA se encontram em posição confortável em relação aos volumes de água produzidos em relação aos demais. Porém, deve-se destacar que há previsão de redução de 31,7\% dos volumes produzidos pelo Canadá e de 40,1\% pelos EUA. Sobre esta redução da produção de água apontada para os EUA e o Canadá é possível inferir situações diferentes que podem ser positivas ou negativas. De modo positivo podemos vislumbrar uma situação em que pode haver desenvolvimento e adoção de técnicas que economizem água ou a aplicação de medidas conservacionistas que pesem sobre a redução da água consumida por habitantes. De outro lado, sob a perspectiva de uma visão mais realista, observa-se que as alterações ambientais provocadas pelo homem nas últimas décadas tem resultado em agravamento da qualidade dos mananciais de água. Deste modo, as extensivas interferências em cursos d’água e em suas áreas de influência, com a expansão de áreas impermeabilizadas, o aumento dos volumes de efluentes dispostos in natura nos corpos 
d'água, aliado ao aumento das demandas produtivas, implicam em grande potencial de redução dos mananciais de água em poucos anos.

A sucinta avaliação acima nos leva a compreender que, apesar destes países terem em comum a destinação da maior fatia do consumo de água para a indústria e isto estar proporcionando atualmente a garantia de uma posição privilegiada no panorama mundial, do ponto de vista econômico, há grande heterogeneidade entre eles quanto à sustentabilidade deste modelo, que é caracterizada pela produção industrial no âmbito local.

Deste modo, a dispersão de empresas industriais de capital internacional ao redor do mundo, preferencialmente em áreas com grande produção de água, também estaria aliviando o mercado interno nacional das novas pressões por demandas de água. Nota-se, neste sentido, que além das demandas internas por parte de países grandes produtores de água, tem havido uma crescente demanda de água por parte de empresas estrangeiras localizadas em território alheio e isto, sem dúvida, também é um fato que deve ser considerado como de atratividade por parte das corporações transnacionais que prestam serviços de saneamento básico.

Observa-se, portanto, que a escassez pode ser manejada, e até mesmo transformada em estratégia de desenvolvimento econômico por parte destas corporações.

Ainda assim, o crescimento industrial é uma ameaça aos volumes existentes, já que a velocidade de consumo de água é superior ao da recarga dos mananciais, sem falar na problemática da poluição dos cursos d’água, que inviabiliza de modo crescente o uso de vários mananciais.

Além da própria demanda de água para o processo produtivo a indústria, principalmente no caso brasileiro também demanda energia, que por sua vez, está fortemente relacionada à geração hidroenergética, necessitando também de água. Devese observar aqui, a título de informação, que grandes grupos privados transnacionais, atuam também fortemente no setor energético, a exemplo da empresa subsidiária “Tractebel Energia”, pertencente ao grupo Suez SA.

O avanço tecnológico, por sua vez permite distribuir água de forma mais rápida e cômoda, por meio de sistemas complexos tais como de aquedutos, transposição de bacias ou mesmo, em casos extremos, por meio de navios cargueiros. Deste modo, a possibilidade de explorar água e transportá-la de forma eficiente de um local a outro do 
planeta também contribui para a aceleração do consumo, já que o possível esgotamento das fontes locais não significa necessariamente um entrave definitivo ao crescimento econômico.

A problemática do crescimento do consumo mundial de água e da perspectiva de esgotamento de muitos mananciais é evidente, porém sua mensuração é complexa e ainda insuficiente para uma avaliação pormenorizada devido às dinâmicas econômicas, políticas e sociais de cada país envolvido. Portanto, as projeções pessimistas sobre o futuro das reservas de água no planeta têm contribuído muito mais com os interesses econômicos que se apóiam na crítica ao Estado, enquanto instância de gestão, do que para a resolução dos problemas propriamente ditos.

Neste sentido, a potencialidade de escassez abre a possibilidade de atuação da iniciativa privada no setor de saneamento básico, de atender as necessidades de expansão dos mercados financeiros e ampliar a centralização e concentração de capital por meio do controle de pontos estratégicos da produção de água sob a gestão de empresas do mesmo grupo.

Porém, a aceitação da privatização da gestão dos serviços de saneamento básico por parte de grande parte da sociedade não é tão direta e fácil quanto aparenta ser. Esta aceitação depende da forma como é concebida a água, como um bem comum ou como um recurso.

Concebida como bem comum, a gestão privada do saneamento básico em geral é questionada, já que a finalidade de acumulação de capital se choca com a priorização de demandas sociais, estas últimas relacionadas diretamente à capacidade de universalização dos serviços e da possibilidade de garantir o atendimento às populações incapazes de arcar com os custos destes serviços.

Por outro lado, concebida como recurso, a gestão privada dos serviços de saneamento é bem aceita, já que propiciaria a reprodução ampliada do capital por meio do lucro obtido pelas receitas advindas do pagamento de tarifas e do rendimento das ações no mercado financeiro.

Na tentativa de compreender o aprimoramento e o ganho de espaço de atuação da corrente econômica que defende a privatização dos serviços de saneamento básico, buscamos resgatar o processo de transformação conceitual do elemento água de "bem comum” em "recurso". 
Deve ser observado que o crescimento do interesse pela prestação de atividades relacionadas ao saneamento básico só passou a ocorrer quando a água, enquanto elemento da natureza deixou de ser reconhecida somente como um bem passível de uso comum, em que o objetivo principal dos serviços é atender as necessidades de reprodução da vida para ser reconhecida como recurso. Reconhecida enquanto recurso a água passa a ser utilizada para atender prioritariamente as necessidades de reprodução do capital.

A água compreendida como recurso pode ser valorada como um bem econômico do qual se pode obter lucro com sua exploração ou rendimento, por meio da intermediação de empresas de prestação de serviço no mercado financeiro.

Deste modo, paulatinamente, o conceito de recurso tem se imposto ao conceito de bem comum e transformado as relações existentes que envolvem o homem e a água e influenciado interesses econômicos.

Na definição de Raffestin (1993, p.225) o "recurso é o produto de uma relação” que envolve um "ator", uma "técnica mediatizada pelo trabalho" e uma "matéria”. Na visão do autor a matéria só poderia ser transformada em recurso na medida em que passa a ser útil e inserida no processo de produção.

Raffestin (1993) apoiado em Becht (1975) ainda completa afirmando que não há recursos naturais, só matérias naturais.

Esta definição fica clara para muitas “matérias” dispostas na natureza, tal como o carvão, o sílex, o ferro, etc. Estas "matérias” só passam a ser recursos quando pela ação humana são criadas utilidades para as mesmas, integrando-as em um processo produtivo.

No processo de introdução destas matérias ao processo produtivo deve ser lembrado o papel do desenvolvimento tecnológico, já que à medida que são criadas novas técnicas de produção, novas matérias são utilizadas. Para exemplificar este fato é possível citar a criação da máquina a vapor, que utilizava grande quantidade de carvão para produção de energia. O carvão, neste período, portanto, foi caracterizado como um recurso natural importante, não só por proporcionar calor àqueles que dele necessitavam em suas necessidades domésticas, mas principalmente para a indústria, para a reprodução do capital. Com o desenvolvimento tecnológico logo a máquina a vapor foi substituída pela elétrica e outras matérias tomaram o lugar do carvão, como a água, para a geração de hidroeletricidade. 
É possível notar que nem todo recurso natural adquire importância econômica suficiente para ser valorizado por si mesmo, como o ouro ou o Petróleo. Em grande parte os recursos naturais adquirem importância temporária enquanto há demanda de utilização em determinado processo produtivo. Contudo, alguns recursos naturais mantêm seu status de importância permanente, seja devido à grande escala de sua utilização em diversos processos produtivos (a exemplo do petróleo), devido à representação simbólica assumida perante a economia mundial (a exemplo do ouro), ou devido à sua potencialidade de escassez frente às demandas associado à sua impossibilidade de substituição (a exemplo da água).

Em relação à água há ainda um tênue limite que dificulta a definição de sua classificação como matéria natural ou como recurso.

A água mesmo em seu estado puro, ou seja, como matéria natural, sem envolvimento no processo produtivo, possui seu caráter de essencialidade. Ela é necessária à reprodução da vida e, portanto, possui uma utilidade intrínseca.

Até as fontes de água límpidas, ainda não utilizadas efetivamente no processo produtivo, podem estar nele inseridas. É a percepção sobre a existência da água e sobre a sua utilidade futura que potencializa a transformação destas fontes em recursos e, deste modo, mesmo antes da introdução efetiva da água no processo produtivo, pode-se dizer que ela já é um recurso.

Isto não transforma a água em um recurso nato, já que se faz necessária a percepção sobre sua potencialidade de uso, ou seja, sobre a potencialidade de sua utilidade. Esta percepção e a utilização efetiva da água são partes da evolução histórica e técnica da humanidade.

Certamente desde que a vida humana se desenvolveu na Terra a água já era reconhecida como essencial, mas há dois momentos importantes a serem destacados: o da conscientização de sua utilidade e o do conhecimento sobre sua espacialização.

Pode-se afirmar que a água era “matéria” natural quando ainda não havia a consciência sobre sua utilidade produtiva e conhecimento desenvolvido sobre sua espacialização.

A evolução da conscientização sobre a utilidade da água na vida humana está associada à reprodução da vida e das relações sociais. Desta forma, o homem, entre os demais seres que habitam o planeta, evoluiu de coletor para produtor e, principalmente, 
por meio do desenvolvimento tecnológico, dispõe hoje de ferramentas que lhe permite conhecer com detalhes o espaço em que vive e decidir sobre sua forma de ocupação.

Compreendemos que a água concebida como recurso é, portanto, a matéria cuja percepção humana captou um sentido de utilidade potencial e também é matéria integrada efetivamente à estrutura produtiva. Neste sentido, a transição entre a água enquanto matéria livre no meio ambiente e a água tratada enquanto recurso envolve trabalho e evolução da conscientização sobre sua oferta.

Nota-se que há muito tempo a água é utilizada para finalidade produtiva e caracterizada como "recurso natural”, mas sua valoração enquanto recurso econômico, leva à superação da finalidade produtiva, retornando ao uso da matéria natural em si, valorizada pela possibilidade de sua utilização como capital fictício.

Como lembra Guttmann (1998, p.77) o capital fictício foi definido por Marx, como um tipo de capital financeiro que "abrangeria créditos envolvendo compromissos de caixa futuros (títulos), cujo valor é determinado unicamente pela capitalização do rendimento previsto, sem contrapartida direta em capital produtivo”.

A água enquanto recurso, neste sentido, é objeto de dominação e de poder, como afirma Raffestin (1993).

Este poder, no que concerne aos serviços de saneamento básico, pode ser traduzido pela possibilidade de obtenção de lucro e de renda advinda do monopólio de prestação dos serviços de água, especialmente em áreas urbanas, já que não há alternativas individuais possíveis à obtenção de água e de disposição de esgotos, em especial em áreas com ocupação adensada.

Segundo Karl Marx (1818-1883) o monopólio pode resultar na realização de sobrelucro que pode se transformar em renda. Ainda, Marx afirma que:

“o preço de monopólio é determinado pela ânsia de comprar e pela capacidade de pagar dos compradores, independente do preço determinado pelo preço de produção geral, bem como do determinado pelo valor dos produtos” ${ }^{12}$.

A água por sua vez, sempre será necessária e, portanto, sempre haverá demanda de compra, mas a capacidade de pagar dos compradores nem sempre favorece a realização do sobrelucro o que causa entraves à grande rentabilidade dos exploradores.

\footnotetext{
${ }^{12}$ MARX, Karl. (1818-1883). O Capital: Crítica da Economia Política. Apresentação de Jacob Gorender. SINGER, P.(coordenaçãoe revisão). Tradução de Regis Barbosa e Flávio R. Kothe. São Paulo: Abril Cultural, 1985, p.239
} 
Isto nos leva a questionar se os serviços de saneamento básico seriam capazes de gerar este sobrelucro.

Em se tratando do caso brasileiro, tomamos como base de análise os dados do SNIS, referentes ao ano de 2004, para procurar responder esta questão. Deste modo, a tabela a seguir procura retratar esta capacidade de obtenção de sobrelucro com a comparação entre as receitas e as despesas declaradas por empresas que prestam serviços de saneamento básico para municípios brasileiros em cada uma das categorias.

\section{Tabela 1}

Saldo entre receitas e despesas para categorias de prestação de serviços de saneamento básico em municípios brasileiros em 2004

\begin{tabular}{||l|c|c|c||}
\hline Categorias de Prestação de Serviços & $\begin{array}{c}\text { Saldo Positivo } \\
\text { (\%) }\end{array}$ & $\begin{array}{c}\text { Saldo Negativo } \\
\text { (\%) }\end{array}$ & $\begin{array}{c}\text { S/dados } \\
\text { (\%) }\end{array}$ \\
\hline Regional (Públicas Estatais) & 48 & 48 & 4 \\
\hline Microregional (Públicas e Privadas) & 86 & 14 & - \\
\hline Local (Públicas) & 63 & 30 & 7 \\
\hline $\begin{array}{l}\text { Local (Privada com Administração } \\
\text { Pública) }\end{array}$ & 67 & 33 & - \\
\hline Local (Privada) & 66 & 22 & 12 \\
\hline
\end{tabular}

Fonte: SNIS/2004 - Serviço Nacional de Informações sobre Saneamento. Disponível em: http://www.snis.gov.br

Os dados mostram que em todas as categorias de prestação de serviços, sejam elas públicas ou privadas há uma maior proporção de empresas prestadoras de serviços de saneamento básico que obtiveram saldo positivo na comparação entre as receitas operacionais obtidas e as despesas totais com os serviços.

Nota-se também que o maior saldo positivo aparece na prestação de serviços por empresas microregionais que se apresentam em grande parte como associação entre capital público e privado.

Esta tabela também sugere que tanto empresas privadas como públicas podem ser lucrativas, mas deve ser notado que as estratégias administrativas para a obtenção de lucro nem sempre são positivas para o desenvolvimento dos serviços no âmbito local ou mesmo para as populações que necessitam destes serviços. Em outras palavras isto quer dizer que para se obter lucratividade pode haver grandes cortes de funcionários, congelamento de investimentos, aumento de tarifas e abandono à conscientização em relação à economia de consumo de água. 
Por meio desta mesma fonte de informações também é possível notar as regiões $^{13}$ brasileiras que se destacam em relação aos saldos negativos obtidos na comparação entre as receitas e despesas das empresas prestadoras. Deste modo, podem ser apreciadas no quadro a seguir as regiões que expressam um maior número de saldos negativos como resultado entre receitas e despesas de saneamento básico para cada uma das categorias de prestação de serviços.

Quadro 1

Regiões brasileiras de maiores ocorrências de saldo negativo entre receitas e despesas em saneamento básico por categoria de prestação de serviços

\begin{tabular}{|l|c||}
\hline Categorias de Prestação de Serviços & $\begin{array}{c}\text { Região brasileira com maior saldo } \\
\text { negativo }\end{array}$ \\
\hline Regional (Públicas Estatais) & Norte \\
\hline Microregional (Públicas e Privadas) & Sudeste \\
\hline Local (Públicas) & Nordeste \\
\hline $\begin{array}{l}\text { Local (Privada com Administração } \\
\text { Pública) }\end{array}$ & Centro Oeste \\
\hline Local (Privada) & Norte \\
\hline \hline
\end{tabular}

Fonte: SNIS/2004.

Os dados informam qual região contém proporcionalmente mais saldos negativos no balanço entre receitas e despesas em saneamento básico para cada categoria de prestação de serviços.

Deve ser destacado que as ocorrências retratam as proporções obtidas a partir do total de municípios atendidos por região em cada uma das categorias de empresas prestadoras de serviços. Deste modo, a exemplo da categoria empresa "Local (privada)”, como havia somente dois municípios atendidos na região Norte e um deles (Manaus) apresentava saldo negativo, a região Norte se destacou perante as demais com $50 \%$.

Ainda, é importante notar que a região Norte aparece com alta proporção de saldo negativo em duas categorias de prestação de serviços: a Regional, na qual os

\footnotetext{
${ }^{13}$ É importante lembrar que o Sistema Nacional de Informações sobre Saneamento - SNIS adota a divisão regional do IBGE (divisão político-administrativa).
} 
serviços são efetuados por empresas estatais públicas e as Locais Privadas, entre as quais a “Águas do Amazonas” ligada à Suez S.A.

O destaque da região quanto ao número de saldos negativos entre as empresas prestadoras de saneamento básico aponta para uma situação provável de pobreza por parte da população, repercutindo na incapacidade de pagamento pelos serviços.

Cabe destacar que segundo o IBGE, em 2003, a Região Norte e Nordeste constavam entre as duas regiões de menor renda familiar do Brasil. Entre os Estados da Região Norte, também se deve observar que o Estado do Amazonas era o que apresentava o segundo rendimento mais baixo da região, ficando a frente somente do Estado do Tocantins.

De modo geral é possível inferir que a obtenção de sobrelucro é viável em grande parte dos municípios brasileiros, mas também é importante destacar que esta viabilidade ocorre em decorrência principalmente de aumento nas taxas/tarifas pelos serviços prestados.

Em relação aos municípios brasileiros é possível dentro da proposta deste trabalho uma comparação entre as tarifas médias praticadas em cada categoria de prestação de serviços para o ano de 2004.

Neste sentido, é possível notar que a tarifa mais alta praticada é de responsabilidade da Companhia Riograndense de Saneamento - CORSAN/RS, empresa regional que cobra $\mathrm{R} \$ 3,08 \mathrm{o} \mathrm{m}^{3}$ de água consumida, o que significa que vários municípios atendidos por esta empresa (regional) pagam esta tarifa. A segunda maior tarifa aplicada é de R $\$ 2,55$ o m$^{3}$ aplicada para o município de Novo Hamburgo/RS pela empresa de direito público local, seguido de $\mathrm{R} \$ 2,35 \mathrm{o} \mathrm{m}^{3}$ aplicada para o município de Caxias do Sul/RS também por empresa de direito público local. Cabe destacar que as altas tarifas apresentadas para estes dois municípios atendidos por empresas de direito público local elevam a média das tarifas da região Sul, que é de $\mathrm{R} \$ 1,63 \mathrm{o} \mathrm{m}^{3}$. Isto mascara a realidade no que diz respeito ao atendimento prestado por empresas de direito público locais na região, já que cerca de $80 \%$ destes municípios possui tarifas abaixo desta média.

A quarta tarifa mais cara $\left(\mathrm{R} \$ 2,25 \mathrm{o} \mathrm{m}^{3}\right)$ é a aplicada pela Companhia de Águas e Esgotos de Rondônia - CAERD/RO, empresa regional, o que significa que cada município atendido pela empresa arca com esta tarifa e, a quinta tarifa mais cara é 
aplicada pela empresa privada Águas do Amazonas na cidade de Manaus/AM (R \$2,15 o $\left.\mathrm{m}^{3}\right)$.

Ao destacar as tarifas acima, em relação às demais, deve ser também avaliada a capacidade de pagamento da população em cada um destes municípios. É possível notar que as três maiores tarifas são aplicadas em municípios do Estado do Rio Grande do Sul.

Apesar da população da região Sul apresentar altos índices de renda média, pode-se afirmar que a concentração de renda presente na realidade econômica da sociedade brasileira encobre condições de precariedade e pobreza mesmo em locais de predomínio de alta renda. Isto implica em possibilidades de exclusão do acesso à água pela incapacidade de pagamento.

Por sua vez, se há possibilidade de exclusão de populações em regiões que são consideradas exemplos de crescimento econômico nacional esta possibilidade se agrava em porções do território em que a pobreza econômica é a regra e não a exceção. Deste modo, altas tarifas aplicadas aos municípios da região Norte como ocorre com aqueles atendidos pela CAERD/RO ou pela Águas do Amazonas, preocupa de antemão.

Outra relação possível de ser analisada com base nos dados do SNIS é a entre tarifas aplicadas e o saldo obtido entre receitas e despesas. Nota-se que com exceção do município de Caxias do Sul, atendido por empresa de direito público, as demais empresas apesar das altas tarifas aplicadas apresentam saldo negativo entre receitas e despesas. Isto demonstra, de certo modo, que o aumento das tarifas isoladamente não permite a obtenção do equilíbrio financeiro da empresa, ou ainda, não corresponde necessariamente aos investimentos no setor.

Neste sentido, deve ser considerado que a obtenção do sobrelucro muitas vezes pode ser dificultada pelo fraco poder de compra/pagamento da população, pela inadequação da estrutura administrativo-produtiva ou ainda, pelas características físicas ${ }^{14}$ da empresa ou dos recursos hídricos explorados.

A inadequação da estrutura administrativo-produtiva pode ser ilustrada pelo inchaço do aparelho funcional ou pela falta de capacitação profissional. Por sua vez, a necessidade de investimentos em manutenção devido à precariedade do patrimônio

\footnotetext{
${ }^{14}$ Como característica física da empresa compreende-se seu patrimônio físico, como prédios e equipamentos necessários à produção e as redes (tubulações por onde correm a água e o esgoto) propriamente dita. Como característica física dos recursos hídricos pode ser compreendida a qualidade do ponto de vista da potabilidade, da coloração e distância dos pontos de demanda.
} 
físico da empresa ou a necessidade de investimentos em melhoria da qualidade dos recursos hídricos ilustram como as características físicas são parâmetros que devem ser considerados para avaliação da capacidade de obtenção do sobrelucro.

Em relação a isto, o argumento utilizado pela empresa “Águas do Amazonas” para justificar os fracos investimentos em expansão das redes de abastecimento e coleta e tratamento de esgoto, justamente é o de que a empresa, durante o processo de concessão, teria sido supervalorizada em termos de estrutura física e mesmo em termos da qualidade da água e ao adquirir a responsabilidade pelos serviços a concessionária teria se deparado com um quadro diferente do descrito. Deste modo, a empresa afirma terem sido necessários os investimentos em reformas, em automação, em substituição de tubulações da rede e em melhoria nas etapas de tratamento da água distribuída.

Mesmo assim, a prestação privada dos serviços de saneamento básico pode ser atraente. Segundo Marx (1818-1883) quando a renda de monopólio torna-se dificultada pela incapacidade de pagamento dos compradores, esta pode ser substituída pela renda de mineração.

Nota-se que na renda de mineração, não há possibilidade de se obter grandes lucros e, portanto, segundo Marx "só podem ser exploradas vantajosamente pelo proprietário da terra, que como seu próprio empresário, obtém o lucro normal a partir de seu capital investido" ${ }^{15}$.

Para esta situação, a exploração dos serviços de saneamento básico poderia ser lucrativa se a gestão das fontes, dos mananciais for propriedade da mesma instância que a irá explorar. Em caso contrário, ou seja, em caso de necessidade de pagamento para a obtenção da concessão de exploração, ou pagamento pelo uso da água, não seria possível alcançar o que Marx conceitua como "renda de mineração"16.

Apesar das águas que correm em território brasileiro serem consideradas públicas, caracterizadas como bem comum do seu povo, a gestão dos serviços vinculados à água não estão totalmente sob a tutela do Estado. Mas, apesar dos serviços de saneamento básico, no Brasil, estarem parcialmente geridos pela iniciativa privada, pode-se dizer que a maior parte dos municípios é atendida por instituições públicas.

\footnotetext{
${ }^{15}$ MARX, Karl (1818-1883). O Capital: Crítica da Economia Política. Apresentação de Jacob Gorender. SINGER, P.(coordenaçãoe revisão). Tradução de Regis Barbosa e Flávio R. Kothe. São Paulo: Abril Cultural, 1985, p.238.

${ }^{16}$ Ibidem, p.238
} 
Estas instituições públicas estão divididas em: empresas prestadoras de âmbito regional, empresas prestadoras de âmbito microregional, e de âmbito local. Entre as empresas prestadoras de âmbito regional pode-se citar a Sabesp - Companhia de Saneamento Básico do Estado de São Paulo, que atende várias cidades e núcleos urbanos dos municípios do Estado de São Paulo, também há a Sanepar no Estado do Paraná, a Sanesul em Mato Grosso do Sul, entre outras. A Cosama, no Estado do Amazonas fazia parte destas empresas regionais.

Assim como a Sabesp, que atende cerca de 3,5 milhões de habitantes, várias outras empresas regionais atendem os aglomerados urbanos de outros Estados brasileiros, incluindo suas capitais.

As empresas prestadoras de âmbito microregionais como é o caso da Prolagos S.A. no Rio de Janeiro, atendem em média de 100 a 500 mil habitantes e em 2002 o SNIS apresentava 6 empresas prestadoras microregionais.

Por sua vez, as empresas prestadoras locais subdividem-se em: de direito público $^{17}$, de direito privado com administração pública e em empresas privadas. Nos três casos as populações atendidas não ultrapassavam (em 2002) os 500.000 habitantes para cada uma das três categorias de prestação de serviços.

Segundo informações obtidas pelo SNIS, no que concerne aos serviços de saneamento básico prestado por empresas locais no território brasileiro, em 2001 havia cerca de 238 municípios sendo atendidos por empresas de direito público, 8 municípios atendidos por empresas de direito privado com administração pública, e 15 municípios atendidos por empresas privadas, sendo que deve-se destacar que em 2001 os dados do SNIS ainda não classificam o município de Manaus como atendido por empresa privada, apesar da concessão ter ocorrido no ano 2000.

Em 2004, os números se alteraram bastante. Eram 295 municípios atendidos por empresas de direito público, 12 por empresas de direito privado com administração pública e 32 por empresas privadas. Isto mostra uma grande expansão da atuação do serviço privado.

Esta expansão não ocorreu de forma homogênea em todas as regiões brasileiras. Segundo o SNIS as regiões as quais mais expandiram a atuação dos serviços privados são as regiões Centro Oeste e Sudeste. Deve-se ressaltar que a Região Centro Oeste

\footnotetext{
${ }^{17}$ Deve-se destacar com base nas informações do Sistema Nacional de Informações sobre o Saneamento SNIS que os prestadores de serviços de abrangência local de direito público, em sua maioria se organizam como autarquia, regidos pela Lei 4.320/04, não apresentando dados de balanço.
} 
quadruplicou o número de municípios atendidos por empresas privadas e dentro da região o Estado de Mato Grosso tem liderado em atribuir à iniciativa privada a tarefa da prestação dos serviços de saneamento básico.

Apesar do crescente número de privatizações não é possível afirmar que esta é uma tendência que será adotada, já que a maior parte dos municípios brasileiros ainda está enquadrada em outras categorias, como pudemos apontar. Porém, estes dados mostram que apesar da política nacional ter acenado com um outro rumo com a vitória de Lula nas eleições presidenciais para 2003 e com a ascensão de lideranças da Frente Nacional de Saneamento Ambiental - FNSA a posições-chave na Secretaria Nacional de Saneamento, como lembra Vargas e Lima (2004, p.68), a política de governo da atual gestão federal (governo “Lula”) tem se mostrado favorável ao aumento da participação privada na área da infra-estrutura, estimulando as chamadas "Parcerias PúblicoPrivada”- PPP e continua refreando investimentos da União em saneamento.

Frente a este contexto, pode-se afirmar que o fator econômico é o mais incisivo entre os principais fatores que induziram e continuam a induzir a concessão da prestação de serviços de saneamento básico à iniciativa privada. Além deste fator também se pode considerar que o discurso do domínio de novas tecnologias e da capacidade de implementação da produtividade também fazem parte dos instrumentos de pressão sobre os poderes de decisão.

Como as questões econômicas servem constantemente de apoio e de instrumentos de pressão política, a associação do discurso de domínio da técnica e da produtividade ao interesse de participação de um novo mercado que se abre (o mercado da água) têm contribuído para a difusão da força de penetração de grandes corporações na prestação dos serviços de saneamento básico.

Sendo a água um bem público que está sob a tutela do Estado, para a obtenção de seu controle é necessária a obtenção da concessão de prestação dos serviços e da outorga de exploração da água.

No que concerne à iniciativa privada, a concessão dos serviços de saneamento, em especial a partir de meados da década de 1990, passou a ser oferecida mediante duas formas possíveis, a concessão onerosa ou a concessão de menor tarifa, esta última associada também a critérios outros como de capacidade técnica. A concessão por menor tarifa, como ocorreu no caso de Limeira-SP não envolve dispêndio de grandes somas de dinheiro no ato da concessão, mas há comprometimento em contrato firmado 
sobre investimentos a serem destinados ao setor por parte da empresa concessionária, bem como de garantias de manutenção da tarifa baixa por determinado período.

Como para a obtenção das concessões dos serviços de saneamento as empresas privadas em geral disponibilizam grandes somas de dinheiro, seja para garantir os investimentos iniciais exigidos, seja participando de concorrências (concessão onerosa), não é possível afirmar que há possibilidade de obtenção de renda de mineração para estes casos. Mesmo com a obtenção de lucro com a aplicação de tarifas/taxas altas, para este caso ainda o que vale é a renda de monopólio, que continua a depender da capacidade de pagamento da população.

Neste contexto, a forte potencialidade de inadimplência, advinda da incapacidade financeira por parte de grandes parcelas da sociedade em arcar com os custos das altas tarifas, adicionado ao grande ônus oriundo do processo de concessão (onerosa) e de investimentos para o cumprimento de metas, não contribuem como fator de atratividade à atuação no setor da iniciativa privada. Porém, mesmo assim, de acordo com o SNIS e também de acordo com a Associação Brasileira das Concessionárias Privadas de Serviços Públicos de Água e Esgotos - ABCON são cerca de 50 os municípios brasileiros que já delegam seus serviços à iniciativa privada, contabilizados nesta última estimativa as empresas microrregionais e as privadas com administração pública.

A compreensão do fator de atratividade só é possível ao considerarmos a criação do mercado internacional da água. Este, por sua vez, está associado à liberalização dos mercados financeiros mundiais ocorridos em meados da década de 1980 e ao desenvolvimento técnico científico, gerando condições ideais para a obtenção da renda de monopólio que extrapola a possibilidade de obtenção de lucro somente pela exploração dos serviços no âmbito local.

É por meio da atuação das grandes corporações no mercado da água, com a emissão de títulos negociáveis de suas empresas, que por sua vez atuam na prestação de serviços de saneamento básico em grandes áreas produtoras de água, que se manifesta o sobrelucro e a obtenção de renda de monopólio.

Neste contexto, é comum empresas ligadas aos grandes grupos como a Suez S.A. aplicarem tarifas altas, mesmo em situações de predomínio de populações com baixa renda, para obtenção de lucro, cujo objetivo inicial é a recuperação do capital investido no processo de concessão. 
O monopólio da água por parte de empresas sob a égide deste grande capital transnacional permite não somente a ampliação de poder de barganha em relação à fixação dos preços dos serviços, como ressaltado por Vargas e Lima (2004), proporcionando as super-taxações, mas também permite a possibilidade de sobre-lucro pela própria potencialidade de controle de áreas estratégicas na compreensão do mercado internacional da água, como é o caso da Bacia Amazônica e do Aqüífero Guarani.

Em relação às estas áreas estratégicas, é curioso notar também que a região Centro Oeste, mais especificamente o Estado do Mato Grosso foi uma das áreas em que mais apresentou a expansão das concessões à iniciativa privada. Deve ser ressaltado também que, além de municípios como Cárceres, Campo Verde, Canarana, Guarantã do Norte, Marcelândia, Matupá, Pedra Preta, União do Sul, Vera e Nova Xavantina que constam recentemente nas listagens do SNIS como atendidos pela iniciativa privada (de abrangência local e microregional) também há aqueles municípios que a ABCON em 2005 apontava como em fase de levantamento de dados, como: Alta Floresta, Arenápolis, Barra do Garças, Cólider, Juara, Juscimeira, Itapema, Itaúba, Nortelândia, Peixoto de Azevedo, Pontes e Lacerda, Santa Carmem e São Pedro de Cipa.

Estes municípios em grande parte estão situados ao longo de cursos d’água que compõem a Bacia Amazônica e alguns situam-se também próximos ou em áreas de afloramento do aqüífero Guarani.

A localização geográfica destes municípios nos leva a refletir sobre a expansão da atuação da iniciativa privada sobre áreas de grande produção de água, o que reforça a idéia de que a característica de produção de água do território é um dos fatores de atratividade da iniciativa privada.

Entre os fatores que também têm contribuído para o avanço do movimento de expansão da atuação privada nos serviços de saneamento básico, como lembra Vargas e Lima (2004) pode ser citado o apoio do governo federal a instituição das PPP e a diminuição de repasse de investimentos federais destinados ao setor de saneamento básico. As parcerias têm sido possíveis a partir da municipalização dos serviços, ou seja, da retomada da titularidade em torno do direito de prestação dos serviços de saneamento por parte do município e a sua concessão à iniciativa privada.

Em geral, o poder concedente busca a concessão onerosa, o que pode resultar em benefícios financeiros imediatos ao município, mas também em futuros problemas no 
que concerne às tarifas a serem aplicadas, que ficaria a cargo da empresa concessionária.

Ainda, sobre a municipalização é possível notar que em alguns casos, a busca da retomada da titularidade por parte do poder municipal não diz respeito necessariamente ou unicamente à defesa dos interesses públicos. Os escândalos em torno de alguns processos de licitação envolvendo a concessão dos serviços à iniciativa privada têm auxiliado na compreensão do jogo de interesses envolvidos.

Ao exemplo disto pode ser citado o caso do município de Sorriso no Estado do Mato Grosso no qual se tornou público o questionamento do Ministério Público do Estado sobre o envolvimento do prefeito José Domingos Fraga Filho (PMDB) sobre favorecimento na privatização da água ${ }^{18}$.

Deste modo, apesar do grande aumento de concessões à iniciativa privada no Estado do Mato Grosso e da coincidência em torno das características físicas, a avaliação do processo de concessão dos serviços de saneamento à iniciativa privada em cada município deve ser analisada individualmente e de forma criteriosa. Para cada localidade devem ser pesadas as políticas, as características físicas e a dinâmica social e econômica local, que traduzem necessidades específicas que devem ser consideradas pelas instituições gestoras.

Entretanto, a avaliação mais abrangente não deve ser descartada, devendo ser considerada como possibilidade de reconhecimento de padrões que podem ser instrumentais importantes ao planejamento regional e a tomada de decisões sobre qual o melhor sistema a ser adotado.

\footnotetext{
${ }^{18}$ Conforme Diário de Cuiabá, Edição n. 9946 de 10/05/2001. Disponível em: http://www.diariodecuiaba.com.br/detalhe.php?.cod=51426
} 


\section{As formas de valoração da água}

Até o momento vimos que a água tem apresentado uma crescente demanda e de certo modo, risco de escassez devido às suas características de quantidade e qualidade no âmbito local. Vimos também que a idéia de escassez pode ser capturada como estratégia da ampliação do capital privado internacional.

Contudo, para que se complete esta estratégia é necessária a dominação do território de produção de água, que pode ser obtido, em certo sentido, por meio das concessões dos serviços.

Neste sentido, a expansão territorial das concessões em pontos de grande produção de água, reflete a estratégia de valoração econômica da água por parte dos grupos privados transnacionais a exemplo do grupo Suez S.A.

Como forma de analisarmos a relação entre a obtenção de pontos de operação com a área de ocorrência de água, procuramos mapear as subsidiárias do grupo Suez S.A, relacionadas aos serviços de saneamento básico, divulgadas pelo Consórcio Internacional de Investigação Jornalística ${ }^{19}$.

O mapa a seguir procura contemplar como base as maiores áreas de ocorrência de água e a localização de cidades as quais o grupo Suez S.A. adquiriu a concessão dos serviços de saneamento básico.

\footnotetext{
${ }^{19}$ CONSÓRCIO INTERNACIONAL DE INVESTIGAÇÃO JORNALÍSTICA. The water barons. Parent Organization: Suez - Subsidiáry: Ondeo. Agosto/2006. Disponível em: <

http://www.publicintegrity.org/water/db.aspx?act=db\&sec=prm\&par=6\&sub=30 $>$ Acesso em 13/08/06.
} 


\section{Mapa 1}

Ocorrência de água mundial e concessões do grupo Suez S.A.

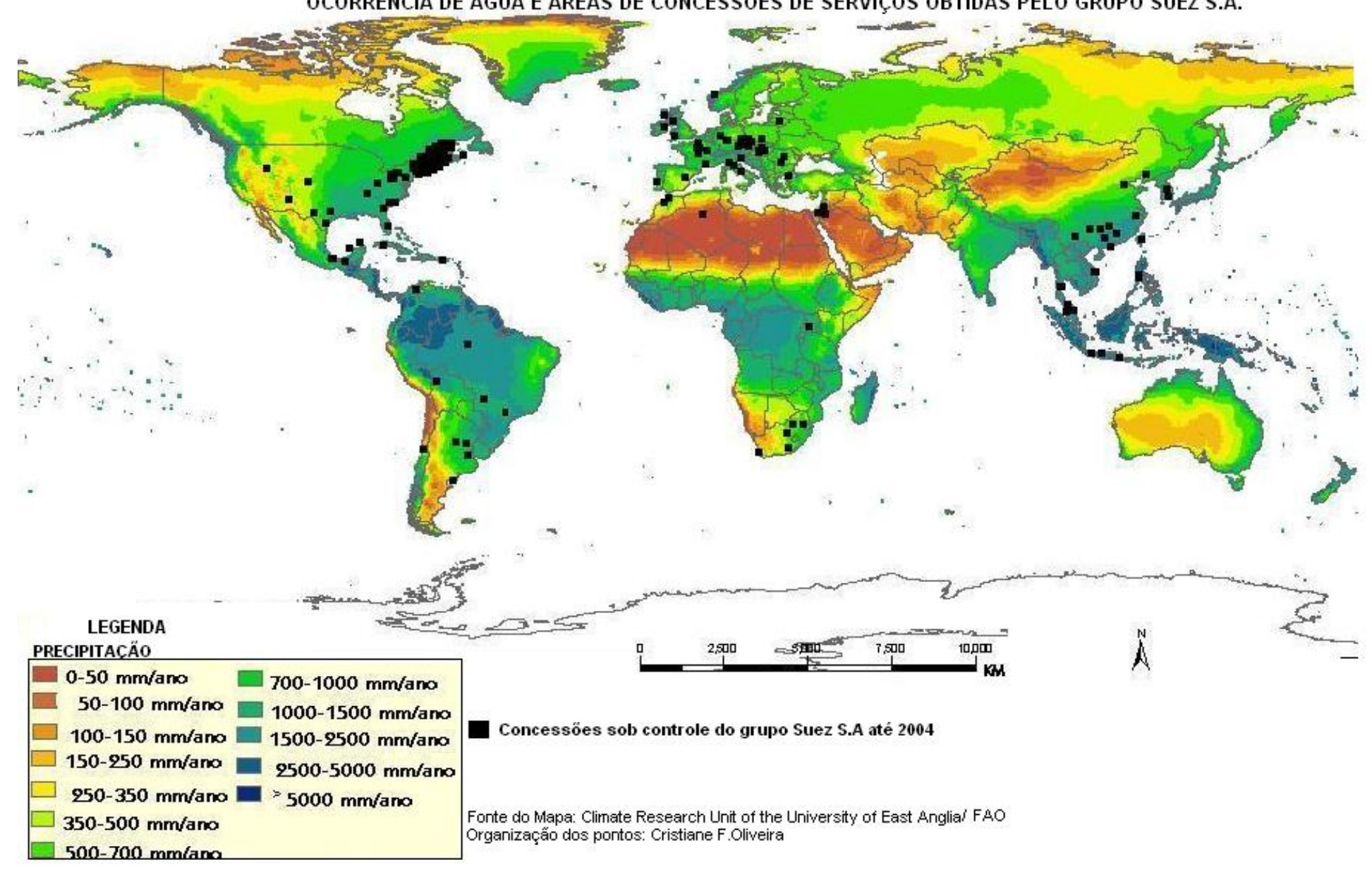


Nota-se que a grande maioria dos pontos coincide com as áreas onde ocorre grande produção de água e, para o caso da Europa e EUA, coincide também com áreas com grandes demandas imediatas por água, estas últimas com potencialidade de boa rentabilidade devido à capacidade de pagamento da população.

Esta espacialização além de apontar os locais onde presta serviços, também aponta de maneira simbólica a potencialidade de exploração e seu poder de gestão em relação aos recursos hídricos mundiais. Contudo, esta simbologia de poder é mais bem decifrada por aqueles que interagem no chamado "mercado da água”.

A criação deste mercado, por sua vez, apesar de estar relacionado originalmente à corrente que defendia que o pagamento pela água geraria uma maior conscientização sobre a necessidade de um uso parcimonioso da água, acabou por transformá-la em um commoditie. Este novo negócio tem garantido a quem possui seu monopólio, seja ele simbólico ou real, o vislumbre de grande rentabilidade financeira por meio da valorização de ações na bolsa de valores.

Contudo, as razões para investimento em ações de empresas voltadas para o saneamento básico não dizem respeito necessariamente à promessa de crescimento dos investimentos em ampliação do território de atuação. Como publicado pela Gazeta Mercantil $^{20}$ o Banco Fibra anunciou a troca de investimentos de ações da Cia. Vale do Rio Doce PNA por ações da Sabesp ON em razão da potencialidade de baixa do dólar, o que permitiria ganhos por parte de empresas endividadas em dólar, como a Sabesp e, consequentemente o aumento do valor das suas ações.

A publicação deste fato, certamente impulsionou, apenas dois dias depois, a matéria publicada na Gazeta Mercantil ${ }^{21}$ que afirma que algumas das empresas privadas do setor de saneamento básico, “(...) como a Ondeo Services, do grupo belgo-francês Suez, gigante mundial do saneamento e energia, demonstram o desejo de ampliar, com vigor, suas áreas de concessão e volume de investimentos. Todas elas querem transformar sua atuação em vitrines para a geração de novos negócios no futuro”.

Deste modo, nota-se que a busca pela valoração da água, enquanto recurso fundamental para a reprodução da vida humana e enquanto recurso indutor da produção na vida humana, por meio da criação de um mercado, tem sido relegada a segundo plano em razão de sua ânsia pela valorização econômica.

\footnotetext{
20 Com câmbio mais estável, banco troca indicação de Vale por Sabesp. Gazeta Mercantil, São Paulo, 07/10/2002.

${ }^{21}$ Gazeta Mercantil. Pioneirismo em saneamento implanta vitrines pelo país afora. São Paulo, 09/10/2002.
} 
A criação de um mercado para a água implica no fortalecimento de um modelo econômico-financeiro internacional e, como alertou Raffestin: "fez esquecer, voluntariamente ou não, que todo mercado era, além de um lugar ou de uma relação de troca, uma relação de poder no sentido mais puro”"22.

Ao se conceber a água como recurso e ao se instituir um mercado para sua negociação se afirma consequentemente, uma relação de poder, sobretudo com base econômica sobre um bem que deveria ser acessível a todos.

Há o risco, na defesa desta concepção de base econômica, do acesso ficar restrito somente àqueles que podem pagar seu preço, que por sua vez passaria a ser estipulado não somente por seu custo de tratamento e distribuição, mas também potencialmente pelo seu valor no mercado.

A corrente econômica que defende a introdução da água no mercado e sua valorização ditada pelo mesmo afirma que isto impulsionaria a conscientização sobre seu uso e proporcionaria maiores condições de investimento, aumentando o seu acesso.

A lógica que ampara esta corrente parece esquecer que quanto maior o consumo maior a arrecadação e que obtenção de maior receita não significa investimentos proporcionais no setor. Ainda, considerando que a decisão sobre áreas que devem receber novos investimentos, sob a ótica empresarial, são aquelas que possuem possibilidade de retorno rápido há grande possibilidade de abandono de planos de atendimento às populações mais carentes. Em geral, grande parte das populações carentes em serviços de saneamento básico, conforme o a Pesquisa Nacional de Saneamento Básico, elaborada pelo IBGE em 2000, situa-se em áreas urbanas periféricas o que demandaria fortes investimentos em extensão das redes sem o retorno econômico esperado.

Outra questão a ser observada é que esta corrente econômica carrega o pressuposto de que todos teriam iguais condições de consumo, o que não é real, principalmente considerando a heterogeneidade de desenvolvimento econômico existente entre as populações de diferentes lugares, o poder econômico diferenciado e até mesmo suas diferentes características físicas ou culturais envolvidas.

Neste sentido, populações urbanas com mesmo poder econômico podem apresentar consumos muito diferenciados em função do acesso às novas tecnologias, que por sua vez, podem estimular o consumo de água ou auxiliar em sua economia. Do

\footnotetext{
${ }^{22}$ RAFFESTIN, Claude. Por uma geografia do poder. Tradução Maria Cecília França, Série Temas vol.29 Geografia e política, São Paulo: Ática, 1993. p.253
} 
mesmo modo, dependendo das características climáticas locais ou da relação cultural das populações locais com a água pode haver um uso maior ou menor deste bem.

Estes fatores, que se traduzem em diversidade de consumo, têm sido entraves a definição de quantidades de consumo que retratem as necessidades básicas por parte das comunidades mais carentes, como aponta Gleick (1996). A definição destas quantidades mínimas necessárias de consumo teria, em princípio, finalidade de melhor planejamento de ação por parte de organismos multilaterais como a Organização Mundial da Saúde OMS, entre outros, que almejam reduzir a exclusão de acesso à água. Porém, bem como decidir qual é o montante de água suficiente, garantir que haja disponibilidade deste mínimo de água necessário ao suprimento das necessidades básicas por parte dos responsáveis pela prestação de serviços de água é algo que ainda se discute.

Da parte dos responsáveis pela gestão e prestação dos serviços de saneamento o discurso de universalização do acesso à água e previsão de grandes investimentos sempre esbarra no esperado equilíbrio financeiro do setor, o que nem sempre é possível.

Quando parte da população não pode arcar com tarifas que possibilitem o equilíbrio entre receitas e despesas as perspectivas são negativas, a menos que haja possibilidade de subsídios cruzados.

Os subsídios cruzados são possíveis a partir da obtenção de lucratividade e esta lucratividade pode ser obtida por meio de aplicação de altas tarifas ou pela possibilidade de diluição das despesas. A diluição das despesas, em geral, é possível nos casos de prestação de serviços em grandes cidades, já que o número de pagantes auxilia na recuperação dos investimentos.

Deste modo, o excedente obtido é repassado como investimento em expansão do acesso aos locais onde a diluição dos investimentos não seria possível ou ao subsídio de tarifas pelos serviços de saneamento básico prestados às populações de baixa renda, incapacitadas em arcar com as tarifas reais.

O subsídio cruzado, contudo, reduz a possibilidade de lucro dentro da lógica privada, o que implica em uma aplicação restrita desta solução para esta categoria de prestação de serviço. Neste sentido, podemos exemplificar esta situação com a avaliação de Vargas e Lima (2004, p.92) para o caso de Limeira. Segundo os autores, o acordo entre a Prefeitura Municipal e a concessionária “Águas de Limeira” resultou na possibilidade de redução de até 50\% na tarifa mínima de água e esgotos para famílias com renda menor ou igual a dois salários mínimos, com duração máxima de um ano, sendo denominada "tarifa residencial popular”, mas atingiu “2,5 mil famílias nesta 
condição até janeiro de 2003, ou cerca de 5\% das famílias de Limeira, enquanto 24\% destas se encontravam naquela condição”.

Deve-se notar que entre os critérios estabelecidos para o recebimento do benefício advindo do subsídio cruzado consta o baixo consumo de água pela família pleiteante, sem o que se estimularia o desperdício.

Em relação ao controle do consumo de água pela cobrança proporcional sobre o montante consumido, defendida pela corrente econômica, é possível afirmar que esta é uma solução parcial já que as disparidades de renda podem até mesmo estimular o consumo por parte da população economicamente mais rica e excluir aqueles mais pobres.

Há também aqueles que defendem que este controle pode ser alcançado de modo cinegético entre as políticas públicas, conciliando o desenvolvimento social, como sugere Martins (2004). Em seu trabalho o autor relaciona a falta de acesso à capacitação e às tecnologias como fatos que contribuem para os altos índices de perda de água na agricultura, especialmente por parte de pequenos agricultores. Do mesmo modo que o autor se utiliza de exemplos de possibilidade de economia de água para o meio rural com a capacitação e disseminação de acesso à tecnologia, também no meio urbano é possível a economia e o reuso de água, talvez até mesmo de forma mais fácil do que no meio rural, mas para isto há necessidade de um trabalho de conscientização continuada, possível por meio da educação.

A valoração da água passa, sobretudo pela informação e pela conscientização social quanto ao direito do seu acesso e quanto ao dever do seu uso equilibrado.

\subsection{Educação e valoração da água}

Partimos do princípio que a questão do gerenciamento do consumo deve relacionar a ação individual e a ação coletiva. A educação é a ação coletiva que pode mobilizar o indivíduo, conscientizando-o sobre a necessidade de uso parcimonioso da água.

Transformar costumes simples e comuns de uso arraigados, que estão baseados na abundância de água como lavar calçadas com mangueiras, banhos demorados de chuveiro, manter torneiras abertas por longos períodos, etc. exige esforços por parte dos agentes educadores. Neste sentido, o trabalho de educação continuada é necessário para que seja criada e mantida a conscientização de economia. 
No entanto, para que o fim de educação seja alcançado um grande número de pessoas deve ser atingido por uma ação organizada, sendo necessária a destinação de investimentos específicos a fundo perdido.

Por sua vez, o papel de educador recai em grande peso sobre o Estado por meio de suas instâncias públicas de governo ligadas principalmente ao setor educacional. Há também, apesar de em menor grau, a possibilidade da interface de atividades educativas com seus órgãos executivos relacionados diretamente com a prestação de serviços, a exemplo das ações continuadas de educação que a Sabesp desenvolve.

Contudo, as ações educativas capazes de atingir grandes populações, como grandes campanhas, são cada vez mais raras em razão de seu alto custo e da contrariedade de interesses envolvidos.

No Brasil a responsabilização do Estado por este papel de educação esteve associada durante muito tempo à característica política centralizadora, na qual o Estado acumulava responsabilidades diversas.

No que diz respeito ao saneamento básico o Estado respondeu sozinho por longo período, por meio de seus órgãos, pela exploração, pelo tratamento e distribuição de água e pela implantação de redes de coleta e tratamento de esgotos. Consequentemente era ele também responsável pela conscientização sobre seu uso e pelos investimentos em educação.

A década de 1990 apresentou um rompimento desta centralização quanto à sua função gestora no que tange aos serviços de saneamento básico, em parte devido à falência do Sistema Financeiro de Saneamento - SFS e, em parte devido à necessidade de ajuste econômico imposto pelo Fundo Monetário Internacional - FMI, que influenciou fortemente nas formulações do Programa de Modernização do Setor de Saneamento. Este programa teria sido fundamentado, como afirma Britto, "na privatização de empresas públicas estaduais”23, as “principais responsáveis pelos serviços" 24 .

Ao transferir a responsabilidade por prestação dos serviços à iniciativa privada, transferiu-se também parte da responsabilidade de conscientização sobre a importância dos recursos hídricos e sobre a necessidade de um consumo equilibrado.

\footnotetext{
${ }^{23}$ BRITTO, A.L. A regulação dos serviços de saneamento no Brasil: Perspectiva histórica, contexto atual e novas exigências de uma regulação pública. In: Anais do IX Encontro Nacional da Anpur - Ética, Planejamento e Construção Democrática do Espaço. Rio de Janeiro: APPUR, 2001, p.1090.

${ }^{24}$ Ibidem, p.1090.
} 
Porém, se a lucratividade dos serviços está apoiada na possibilidade de consumo, não seria coerente a aplicação de investimentos, por parte da iniciativa privada, que levasse à economia no consumo de água, ou seja, investimentos em campanhas que visam à economia de água.

Para avaliar a atuação das concessionárias ligadas ao grupo Suez no Brasil (Águas de Limeira e Águas do Amazonas) no que concerne ao seu grau de responsabilização no que diz respeito à conscientização da população quanto à necessidade de economia de água, buscamos respostas entre moradores locais em cada uma das cidades envolvidas.

Neste sentido, foi questionado sobre a lembrança acerca de campanhas de economia de água e sobre a responsabilidade da divulgação.

A preocupação neste estudo, sobre a existência de campanhas educativas ou projetos educativos de ampla divulgação sobre economia de água, levantados em entrevistas de campo junto à população amostrada tem o intuito de avaliar o grau de absorção desta responsabilidade por parte das empresas concessionárias ligadas ao grupo Suez SA.

Para tanto, em entrevistas efetuadas em campo com amostras da população urbana municipal pudemos constatar que para o caso de Manaus 68\% dos entrevistados não lembravam de campanhas efetuadas sobre economia de água e entre o total dos entrevistados que lembravam de alguma campanha (34 indivíduos) apenas 47\% conseguiram relacioná-la à instância divulgadora. Sendo que 26\% atribuíram a campanha a um órgão público (escolas, secretarias da saúde, etc.) e 21\% atribuíram a campanha à empresa Águas do Amazonas.

Para o caso de Limeira pôde-se concluir que 50\% dos entrevistados não lembram de nenhuma campanha sobre economia de água. Entre o total dos entrevistados que lembravam 17\% não souberam informar quem a havia divulgado, 17\% relacionaram a campanha à igreja católica (Tema da Campanha da Fraternidade) e, houve empate em relação aos entrevistados que relacionaram a campanha de economia de água a um órgão público e à empresa Águas de Limeira.

Nos dois casos chama a atenção a grande maioria dos entrevistados que não lembra de nenhuma campanha sobre economia de água, o que demonstra abandono à responsabilidade de conscientização da população, seja por parte das empresas responsáveis pelos serviços de saneamento básico, seja por parte do Estado, responsável pelo setor educacional público. 
Deve-se notar que apesar da ausência de um trabalho de conscientização abrangente, com ampla divulgação entre a população em geral, há ações sociais pontuais patrocinadas pelas empresas avaliadas e um setor educacional aberto à visitação de escolas, mediante agendamento prévio.

Do ponto de vista do contrato de concessão, em ambos os casos avaliados (em Limeira-SP e Manaus-AM) não houve preocupação com controle de consumo por parte do poder concedente. Isto reflete na redação dos termos do contrato que demonstra ausência de exigências que poderiam tratar este tema através da cobrança de ações de promoção educativa. A ausência desta exigência desonera a empresa, ao menos do ponto de vista contratual, da responsabilidade de investimentos em educação ambiental, no que concerne especialmente à valorização da água e à sua economia.

Apesar de a educação ser o instrumento que pode permear a construção da cidadania e, no que concerne à água, possibilitar a indução da economia como expressão de sua valorização enquanto bem comum, ainda há situações dialéticas envolvidas em relação ao controle do consumo de água que dificultam a construção de uma previsão otimista.

Ao mesmo tempo em que o conhecimento contribui para conscientização sobre a necessidade de se utilizar a água de forma equilibrada, também o conhecimento sobre a disponibilidade da água possibilita novas estratégias de uso por parte de interesses econômicos.

O uso das reservas de água, frequentemente, não tem respeitado seu tempo natural de reposição. Este uso em geral acompanha o ritmo das demandas, que se aproxima intensamente do ritmo de produção industrial. Deste modo, revela-se um paradoxo entre a existência de volumes constantes de água e demandas crescentes por seu uso, ditadas, em última instância, pelo ritmo de consumo.

Quanto a este fato pouco se pode fazer, já que não há atualmente forças políticas ou sociais organizadas capazes ou dispostas a coibir ou mesmo equilibrar o crescimento industrial.

Neste aspecto o consumo mundial de água tem apontado um ritmo de crescimento, em especial por parte de países industrialmente avançados, como os EUA, mas também por parte daqueles países com grande potencial de crescimento, como a China. 
Em pesquisa efetuada em base de dados da Food, Agriculture and Organization/Aquastat - $\mathrm{FAO}^{25}$, comparando-se dois períodos de exploração de água foi possível obter as seguintes informações que destacavam-se das demais: entre 1988 e 1992 os EUA exploravam $781 \mathrm{~m}^{3} /$ hab/ano de água e no período seguinte, entre 1998 a 2002 o mesmo país explorava $1.647 \mathrm{~m}^{3} / \mathrm{hab} / \mathrm{ano}$. Foi possível notar que houve considerável crescimento de consumo de água dos EUA (110\%) frente aos demais países. Por sua vez, a China também apresentou crescimento, contudo na ordem de $15 \%$.

Ainda, em análise simplificada destes dados é possível notar que mesmo alguns dos países grandes produtores de água têm apresentado pequeno crescimento de consumo, como ocorre com o Brasil cujo consumo de 332,4 $\mathrm{m}^{3} /$ habitante/ano para o período compreendido entre 1993 e 1997 passou a 336,4 $\mathrm{m}^{3} /$ habitante/ano, para o período compreendido entre 1998 e 2002, ou seja, um aumento de 1,20\%.

O pequeno crescimento no consumo brasileiro pode ser até mesmo considerado alto se tomarmos outros exemplos de países latino-americanos grandes produtores de água para comparação no mesmo período, tal como o caso do Peru, da Argentina e do Equador que reduziram respectivamente a exploração de água em 11,64\%, 4,21\% e 8,37\% no mesmo período.

Estas informações apontam o fato de que não há relação direta entre volume de água produzida e desenvolvimento econômico-industrial, mas há relação entre desenvolvimento econômico-industrial e crescimento do consumo de água.

É importante observar que não há dados disponíveis para a análise comparativa dos períodos mencionados para todos os países, sendo que os exemplos a seguir somente podem ser tomados como casos isolados, ainda que aparentem ser representativos. Para estes casos foi possível constatar que tem havido uma redução na exploração de água, apesar de pequena.

Segundo Pochmann (2001, p.58-59) alguns países de tradição industrial como a Inglaterra, vêm apresentando nas últimas décadas uma redução na absorção de mão de obra. Também Dahlman e Frischtak (2005) apontam a ascensão dos serviços como atividades mais desenvolvidas e a transformação industrial, com redução da estrutura produtiva para alguns países, em especial para a Comunidade Comum Européia.

\footnotetext{
${ }^{25}$ FAO/Aquastat. Banco de Dados. In: www.fao.org/AG/AGL/aglw/aquastat/dbase/index.stm. Acesso em 02/12/05.
} 
Essas informações nos auxiliam a compreender a oscilação no consumo de água observado nos dados da FAO. Deste modo, para o período entre 1988 a 1992 o consumo de água da Inglaterra foi de 555,2 m³/hab/ano, para o período de 1993 a 1997 o consumo foi de 523,3 $\mathrm{m}^{3} / \mathrm{hab} / \mathrm{ano}$ e para o de 1998 a 2002 houve um pequeno aumento do consumo para 532,2 $\mathrm{m}^{3} / \mathrm{hab} / \mathrm{ano}$, não superando, contudo, o valor no primeiro período mencionado. A Rússia por sua vez, reduziu em 36,5\% seu consumo de água na comparação dos dados dos períodos de 1988-1992 e 1998-2002 e pode significar também uma redução na produção industrial.

O Brasil apresentou um pequeno aumento no consumo, que não se deveu a um crescimento do setor industrial, mas sim do setor agrícola, como pode ser observado na tabela a seguir:

\section{Tabela 2}

Brasil: Porcentagem do consumo de água por setores para os períodos de 1993-1997 e 1998-2002

\begin{tabular}{||l|l|l|l||}
\hline Período & $\begin{array}{l}\text { Setor Industrial } \\
\mathbf{( \% )}\end{array}$ & $\begin{array}{l}\text { Setor Agrícola } \\
\mathbf{( \% )}\end{array}$ & $\begin{array}{l}\text { Setor Doméstico } \\
\mathbf{( \% )}\end{array}$ \\
\hline $1993-1997$ & 18,12 & 60,93 & 20,96 \\
\hline $1998-2002$ & 17,96 & 61,77 & 20,27 \\
\hline
\end{tabular}

Fonte: FAO/Aquastat 2004, disponível em:

http://www.fao.org/ag/agl/aglw/aquastat/dbase/index.stm

Porém, ainda que seja possível o estabelecimento de algumas relações entre produção de água, consumo e desenvolvimento econômico-industrial, ainda faltam dados que permitam uma análise cruzada das informações. Mesmo assim, é possível prever que a diminuição da oferta de água e o possível aumento de seu preço em função de sua característica de escassez, seja fator de indução ao desenvolvimento de atividades produtivas, especialmente daquelas que consomem grandes volumes de água, fora do território de origem.

Neste sentido, já é possível notar inúmeras empresas industriais norteamericanas atuando ao longo do rio Grande em território mexicano. Porém, o investimento estrangeiro em países cujos territórios são ricos em produção de água, 
como o caso do Brasil, não é ainda observado detalhadamente sob o aspecto do consumo de água.

É importante frisar, no entanto, que ao se instituir a cobrança pelo uso da água, a exploração "barata” da água em território brasileiro, por parte de empreendimentos de origem estrangeira, pode encarecer e deixar de ser atraente, em especial para aqueles que já convivem ou conviverão em breve com o chamado “estresse hídrico”.

Apesar de notarmos que o ritmo de consumo de grande parte dos países supracitados não é significante, com exceção dos EUA e da China, não se pode dizer o mesmo dos países que já convivem com o chamado “estresse hídrico”. Conviver com o estresse hídrico significa conviver com o fato de seus recursos hídricos não proporcionarem o atendimento das demandas por água em um volume per capita de no mínimo $1000 \mathrm{~m}^{3}$ por ano. Deve-se ressaltar que este volume deve atender a todos os setores de consumo: industrial, agrícola e doméstico.

Segundo Rebouças (2004, p.71) o estresse hídrico deve "ser sentido em 2025 em cerca de 33 países membros das Nações Unidas”. Contudo, segundo o autor omite-se o fato de que muitos destes países já convivem milenarmente com a escassez de água e alguns deles têm lidado bem com a questão, como é o caso de Israel que se utiliza da água de forma eficiente, reutilizando-a e exportando tecnologia.

É possível perceber que existem diferentes ritmos de consumo de água no mundo, e da mesma forma que encontramos exemplos de países que vivem confortáveis com a escassez devido ao uso inteligente provavelmente aprendido com a experiência de muitas gerações, também há países que por inexperiência ou baixo poder econômico sofrem com a escassez deste recurso, como: a Líbia, a Jordânia, Ruanda, entre outros. Ainda, por outro lado, há aqueles os quais não sofreram ainda as conseqüências de um consumo desmesurado, por encontrar-se atualmente em posição confortável em relação à capacidade de atendimento das demandas, mas que apresentam perspectivas de dias difíceis, como o caso dos EUA. Também há aqueles que se situam em posição confortável em relação ao atendimento de suas demandas, mesmo dentro de uma perspectiva futura de aumento da escassez mundial de água. Estes últimos, tais como o Brasil, perfazem as reservas mundiais futuras e, a possibilidade de gestão sobre seus recursos hídricos em um contexto de escassez garantiria status econômico a quem a detiver.

Este status se remete por sua vez diretamente a um valor que será capturado pelas empresas por meio de investimentos do mercado em suas ações. 
Neste contexto pode ser compreendida a atuação dos grandes grupos transnacionais no setor do saneamento básico no Brasil que, a exemplo da Suez S.A., por meio de suas empresas Águas de Limeira e Águas do Amazonas, podem proporcionar lucratividade com o atendimento das demandas domésticas e industriais, bem como obter o sobrelucro ao capital que as controla. Este sobrelucro pode ser obtido com a venda de ações em bolsas de valores mundiais, como procuraremos discutir no próximo capítulo.

Neste capítulo vimos que na realidade a entrada da água no mercado econômico não é novidade, já que dela depende toda produção mundial, seja como elemento natural essencial para produção de gêneros primários, bem como integrando etapas da produção industrial ou contribuindo para a reprodução da força de trabalho. Até então, seu valor real se confundia com o do produto final.

Hoje se fala em cobrança pela água, o que implica não apenas na cobrança pelos serviços prestados em relação à captação e distribuição deste recurso natural, mas na fixação de um preço à água em si, que deve ter referência em um determinado valor.

Algumas questões são geradas a partir desta valoração: Quem ou como se estipula seu valor? Quem cobra? Quem ganha e quem perde?

Aos poucos o valor de bem comum se perde e o valor econômico assume posição de destaque no contexto das relações sociais.

A valorização de recursos naturais se dá, sobretudo, em virtude de sua raridade de ocorrência em relação à suas demandas. Portanto, dita a regra da economia que quanto mais raro o recurso e, maior sua demanda, maior será seu valor para o mercado. Neste sentido, o vislumbre da possibilidade de cobrança, associado ao aumento das demandas mundiais e a estabilidade ou diminuição das reservas de água contribuíram para a integração do elemento água no mercado econômico.

Ao analisarmos as discussões ambientais, explicitadas principalmente a partir da década de 1990, observamos um direcionamento específico às preocupações sobre a utilização da água no âmbito mundial, acompanhadas, da construção da idéia de crescimento da escassez e da organização de um mercado constituído especialmente para atender as novas exigências do capital internacional.

Notamos neste contexto, o surgimento de grandes corporações privadas internacionais especializadas na prestação e gestão de serviços ligados à água, tais como saneamento básico e geração de energia. 
Na medida em que as discussões sobre a criação de um mercado da água se desenvolvem, notam-se diferentes atitudes por parte das diversas instâncias (públicas e privadas) envolvidas. Os grandes grupos privados rapidamente se organizam na busca do controle da água, já que até início da década de 1990 a gestão deste recurso estava predominantemente nas mãos de instâncias públicas e, portanto, teoricamente sob o controle do Estado.

Desse modo as políticas públicas de saneamento básico no Brasil refletem este estado permanente de luta alternando períodos de avanços e períodos de estagnação de investimentos, sendo que nos últimos 15 anos esta luta foi incrementada fortemente com a atuação das grandes corporações privadas no setor.

Como já dissemos, estas grandes corporações privadas se organizaram rapidamente em busca da conquista de novos espaços de atuação. Para tanto, alguns novos fatores estão envolvidos: o desenvolvimento e aplicação de novos aparatos tecnológicos, que buscam respaldar sua competência através do domínio da técnica e a capacidade de articulações políticas frente aos órgãos de financiamento mundiais.

De outro lado, as instâncias públicas geridas pelo Estado apresentam-se, em grande parte, desestruturadas financeiramente e débeis quanto a sua organização gestora e participativa, o que tem conduzido a decisões que privilegiam interesses individuais em detrimento dos sociais.

A princípio esta constatação leva à idéia de que a instância privada está mais bem preparada para gerir e prestar serviços relacionados à água e que ao Estado deveria competir somente à regulação da atuação da primeira.

Contudo, a avaliação dos casos discutidos quanto ao aumento das tarifas aplicadas, o abandono de políticas de economia de água, de grandes perdas na distribuição e de fracos investimentos no setor de saneamento nos leva a questionar a atuação destas empresas enquanto forma de atendimento das demandas sociais e enquanto centros privilegiados do ponto de vista técnico.

Devemos, portanto, no próximo capítulo discorrer sobre o aspecto da regulação dos serviços no Brasil, sobre a experiência das concessões internacionais e o desenvolvimento do mercado de ações em relação ao setor de saneamento básico. 


\section{CAPÍTULO II}

A água como estratégia de reprodução ampliada do capital 
No capítulo anterior vimos que a idéia de escassez foi capturada como argumento para o predomínio do aspecto econômico na valoração da água. Essa valoração tem sido o alicerce da corrente neoliberal que defende a transmissão da gestão dos serviços relacionados à água à iniciativa privada, o que tem sido denominado genericamente de privatização.

Neste capítulo procuramos desenvolver a discussão sobre os desdobramentos da valoração econômica da água que contribuem para a reprodução ampliada do capital, possibilitada pelas privatizações dos serviços de saneamento básico.

Iniciamos esta tarefa com a apresentação de algumas formas de privatização assumidas no setor de saneamento básico, bem como da apresentação de modelos de regulação comumente adotados.

Após a caracterização das formas de privatização e regulação existentes procuramos discorrer sobre algumas experiências de privatização do setor.

Sendo assim, procuramos resgatar de forma sucinta a evolução da experiência privada estrangeira no setor de saneamento básico e suas conseqüências para a expansão da privatização dos serviços de saneamento básico no âmbito mundial.

Procuramos também discorrer sobre a experiência brasileira de privatização dos serviços de saneamento básico e sobre o aspecto de regulação do setor, tomando como parâmetro de análise os casos estudados em Manaus e em Limeira.

Finalmente procuramos apresentar neste capítulo, a evolução dos negócios do grupo SUEZ S.A. relacionados ao mercado de ações e às transações financeiras apoiadas na expansão de sua atuação no setor de saneamento básico, com o objetivo de ampliação do capital. 


\section{Privatização do Setor de Saneamento Básico}

As privatizações no Brasil, principalmente a partir da década de 1990, são resultados, segundo Fiori (1995), das reformas do Estado ocorridas na década anterior, que obedeciam as diretrizes neoliberais impostas pelas instituições credoras no que concerne à renegociação da dívida externa. Estas reformas, segundo o mesmo autor, se apoiavam no "tripé do reformismo liberal”" ${ }^{26}$ contendo aspectos de desregulação, abertura econômica e privatizações, aspectos estes também explicitados por Chesnais (1996, p.308).

A denominada privatização de empresas públicas (estaduais ou municipais) tem sido consumada no Brasil sob a forma de concessão dos serviços, na qual, segundo Gouvello (1998, p.197) “a empresa privada opera os serviços por sua conta e risco, arcando com as tarefas de manutenção e substituição das instalações” ${ }^{27}$, bem como pelos investimentos.

Gouvello (1998, p.197) também nos auxilia a compreender outras formas de gestão dos serviços, que derivam do modelo francês de privatização. Entre estas outras formas constam: a denominada "régie directe”, a "régie intéressée” e a "affermage”. A "régie directe"pressupõe a assunção dos serviços pela instância municipal, a "régie intéressée" ou "gérance", é aquela gestão na qual o município assume a responsabilidades pelos investimentos, pelas tarifas e por eventuais déficits, delegando os serviços às empresas contratadas que por sua vez, são remuneradas com um valor fixo ou por produtividade de acordo com o tipo de contrato. Na “affermage” o município arca com o planejamento e investimentos e a operação fica a cargo da empresa privada que se responsabiliza pela "manutenção e substituição das instalações”, ainda, com relação a este último modelo, segundo o mesmo autor, as tarifas ficam acertadas em contrato.

É importante notar que as formas assumidas de privatização dos serviços de saneamento básico, no âmbito mundial, estão relacionadas ao caráter administrativo que as regula e, conforme Silva, estas formas derivam de dois grupos: “do direito francês de

\footnotetext{
${ }^{26}$ FIORI, José Luis. Em busca do dissenso perdido. Ensaios críticos sobre a festejada crise do Estado. Rio de Janeiro: Insight, 1995, p.IX.

${ }^{27}$ GOUVELLO, Bernard de. Gestão dos serviços de abastecimento d’água e esgotamento sanitário: 0 modelo francês e sua exportabilidade. In: SANTOS JR, O.A; PORTO, H.R.L. e BRITTO, A.L. (Orgs.) Políticas de saneamento ambiental: inovações na perspectiva do controle social. Rio de Janeiro: FASE, 1998, p. 197.
} 
concessões” e dos “institutos britânicos e norte-americanos da regulação sobre a oferta de serviços" ${ }^{28}$.

Segundo Silva (1999, p.265) no caso do modelo de regulação francês o Estado sempre mantém a titularidade dos serviços com a permissão de operação por terceiros. Para estes últimos ainda é garantido, em contrato, o equilíbrio econômico e financeiro e a indenização de investimentos realizados não amortizados nos casos de reversão dos serviços antecipados ao período contratado. Como destaca o mesmo autor, neste modelo francês "não há necessariamente uma relação entre a receita tarifária do serviço e a remuneração de seus operadores”, sendo que podem ocorrer diferentes situações, tais como a viabilidade de pagamento de investimentos pelas tarifas, ou o subsídio dos investimentos pelo concedente e a “justa remuneração dos operadores” ${ }^{29}$, que por sua vez, pode determinar o preço das tarifas.

O que deve ficar claro é a ênfase na busca da garantia do equilíbrio econômico para a concessionária (prestador de serviços).

As concessões que optaram pelo modelo britânico ou norte-americano possuem remuneração essencialmente tarifária, já que a titularidade dos serviços nem sempre é Estatal, não havendo subsídios possíveis quando isto ocorre. O agente regulador, de acordo com Silva (1999, p.265) está dissociado do poder de outorga dos serviços.

Como lembra Gouvello (1998, p.205) nem sempre os sistemas adotados são puros, ou seja, eles não seguem estritamente um dos dois modelos supracitados (o francês ou o inglês) devido às influências culturais locais das empresas associadas ou mesmo devido à adoção de sistemas de regulação diferenciados dos modelos de concessão.

No Brasil é interessante notar que os sistemas adotados mesclam características dos dois modelos, como observado por Silva (1999, p.265), sendo que o modelo de concessões francês se associa ao sistema de regulação britânico.

Ambos os sistemas (francês e britânico) foram adotados na concepção dos sistemas de saneamento básico privatizados em vários países, ora em sua forma pura ora em sua forma associada.

Deve-se atentar para o fato de que a adoção de um dos sistemas ou da mescla de ambos em grande parte resulta da origem dos grupos econômicos privados

\footnotetext{
${ }^{28}$ SILVA, Ricardo Toledo. A regulação e o controle público da infra-estrutura e dos seviços urbanos no Brasil. In: DEÁK, C. \&SCHIFFER, S.R (Orgs.) O processo de urbanização no Brasil. São Paulo: FUPAM/Edusp, 1999, p.264-265.

${ }^{29}$ Ibidem, p.265.
} 
transnacionais que conquistam os serviços de saneamento básico no âmbito local. Deste modo, como os grupos relacionados aos serviços de saneamento básico que mais expandem seus territórios de atuação no exterior são os franceses, pode-se dizer que o modelo de concessão francês tem sido o mais aplicado.

Para que possamos compreender melhor a evolução da atuação destes grupos econômicos e sua transformação em ícones de modelos administrativos de concessões e de regulação para outros países, faz-se necessário resgatar um pouco da história da transferência dos serviços de saneamento básico à iniciativa privada na França e na Inglaterra, de onde surgiram os grandes grupos privados do setor.

Também se faz necessário analisar algumas experiências estrangeiras de privatização ligadas ao grupo Suez S.A, que podem nos auxiliar a reconhecer padrões de atuação do grupo no Brasil.

\subsection{A experiência estrangeira}

Como destacado por Britto (1998, p.177) a Lei francesa sobre autonomia municipal de 1884 confere ao município a responsabilidade pelos serviços de saneamento básico. Como são inúmeros os municípios franceses, muitos os quais são pequenos e com fraca capacidade de investimentos, paulatinamente foram sendo adotadas modalidades alternativas para viabilizar os serviços. Dentre estas modalidades, Brito (1998, p.178) destaca o agrupamento de municípios com gestão coletiva dos serviços com a articulação intermunicipal mediada pelos sindicatos intercomunais e a delegação dos serviços à iniciativa privada.

No caso desta última opção, Brito (1998, p.178) destaca que a infra-estrutura e a responsabilidade pela gestão continuam sendo do município e a operação passa a ser responsabilidade da empresa concessionária.

Segundo esta mesma autora 43\% dos municípios franceses, em 1999, continuavam responsáveis pela operação dos serviços, mas a tendência era de diminuição deste índice com o avanço da atuação privada. Entre as empresas citadas pela autora com forte atuação na França em 1999, constava a Générale des Eaux e a Lyonnaise des Eaux, sendo que a primeira foi incorporada ao grupo Veólia Environment e a segunda ao grupo Suez S.A.

É importante esclarecer que os sistemas de coleta de esgoto são predominantemente administrados pelas instâncias públicas, ao contrário dos serviços 
de abastecimento e das estações de tratamento de água que são operadas pela iniciativa privada.

Vale observar ainda que, inseridas como instâncias de gestão as agências francesas de água, como lembra Britto (1998, p.179) são agentes executivos de Bacias, cuja finalidade é planejar e gerir os recursos hídricos com objetivos de alcançar padrões de qualidade e de quantidade de água. Ainda, por meio da ação destas agências francesas de água é que foi possível a implementação considerável do número de estações de tratamento municipais.

Evidentemente tudo isto possui um alto custo, que deixou de ser subsidiado pelo Estado para ser assumido inteiramente pelos usuários por meio das tarifas cobradas pelos serviços. Estas tarifas, no caso francês incluem taxas sobre a água consumida, sobre utilização da água (que é repassada às agências de água), sobre adução de água e taxas referentes aos impostos, como destacado por Britto (1998, p.180). Além da tarifa referente ao abastecimento de água, há também os serviços de coleta de esgotos que são cobrados separadamente, com seus devidos impostos e com uma taxa de poluição (que se destina às agências de água).

Como na França não existe uma instituição criada com fim de regular a qualidade dos serviços e a aplicação de tarifas, a regulação é efetuada por mecanismos construídos historicamente e culturalmente com ampla participação política e social. Entre estes mecanismos Britto (1998, p.180) cita a regulação "pelo mercado”, a regulação "global e política” e a regulação em função “dos serviços públicos”.

A regulação em função dos "serviços públicos” se baseia nos princípios básicos de respeito às necessidades essenciais, e que devem ser garantidos e, portanto, cobrados pelo Estado. De acordo com Meirelles (1994) os serviços públicos devem ser norteados por 5 princípios: de permanência, que envolve a continuidade dos serviços, de igualdade de atendimento, de eficiência, de modicidade das tarifas e de cortesia no atendimento.

A regulação “global e política” pressupõe, conforme Gouvello (1998, p.202) que o poder de voto que os consumidores possuem sobre seus representantes políticos, possam induzir seus candidatos eleitos à agir em prol dos usuários, efetuando um bom trabalho quanto a cobrança e controle das atividades relacionadas ao setor de saneamento básico.

Na regulação pelo mercado a competição entre as empresas, segundo Brito (1998, p.180) geraria um tipo de atuação que leva a busca da imagem de sucesso da empresa, que por sua vez influenciaria seu grau de aceitação com possibilidades de 
expansão de sua atuação. É importante lembrar que são várias empresas que atuam na França, dentre as quais se destacam fortemente as empresas do grupo Suez S.A. e a do grupo Veólia Environment S.A. que competem entre si para a expansão de atuação no mercado interno. A conquista de um lugar de destaque no mercado interno contribuiu para aumentar o poder de influência política destes principais grupos e, por conseguinte, impulsionou a capacidade de expansão de suas atividades ao exterior.

Neste sentido, Fiori (1995, p.113) lembra que o mercado já estaria oligopolizado e, para o caso específico do setor de saneamento básico pode-se afirmar que são poucos os grupos transnacionais que atuam e que, portanto, ditam as regras do mercado, manipulando e capturando as instâncias de decisão.

Devemos lembrar que no caso francês caberia ao Estado a tutela sobre as instâncias municipais para o cumprimento das diretrizes ambientais e sociais relacionadas às políticas públicas para o setor e, deste modo, os municípios seriam cobrados por suas escolhas, quanto à terceirização dos serviços de saneamento.

Contudo, conforme afirma Britto: "Na realidade, diante da estrutura criada e da importância dos agentes privados que atuam no setor, os municípios vêm pouco a pouco perdendo sua capacidade de intervir na gestão dos serviços.” 30

É importante notar também, que associada à perda da força das instâncias públicas de gestão, frente ao poder de atuação dos grandes grupos transnacionais, também ocorre ampla conexão política entre as empresas prestadoras de serviços e instâncias de decisão. Conexões estas que permeiam decisões sobre formulação de regras de atuação ou mesmo o próprio processo de transmissão dos serviços à iniciativa privada.

Vários casos que ilustram estas situações foram descritas pelo Consórcio Internacional de Investigação Jornalística ${ }^{31}$ - . Entre os escândalos franceses envolvendo representantes de governos locais e o grupo Suez S.A. é possível citar o caso da privatização dos serviços de saneamento em Grenoble - FR e do envolvimento do grupo Suez S.A. em contribuição ilegal com o fundo de campanha eleitoral de Alain Carignon, que viria a assumir o posto de ministro de comunicações na França.

\footnotetext{
${ }^{30}$ BRITO, Ana Lúcia. Experiências Internacionais na gestão de serviços de saneamento: os casos da Inglaterra, da França e da Argentina. In: SANTOS JR, O.A; BRITTO, A.L. e PORTO, H.R. (Orgs.) Políticas de Saneamento Ambiental: Inovações na perspectiva do controle social. Rio de Janeiro: FASE, 1998, p.179.

${ }^{31}$ CONSÓRCIO INTERNACIONAL DE INVESTIGAÇÃO JORNALÍSTICA. Water and power: the french connection, 2003. Disponível em: < http://www.icij.org/datweb/water/PrintReady.aspx?AID=4 > Acesso em 04/06/03.
} 
Em 1994 Carignon respondeu a processo por corrupção e foi sentenciado a 5 anos de prisão mais pagamento de multa. Os executivos da Suez Jean-Jacques Prompsy e Marc Michel Merlin bem como Jean Louis Dutaret (lobista do grupo) também foram sentenciados com prisão e multa.

Em 1999 um novo processo foi movido contra a Suez na França por superfaturamento e por cobrança indevida aos usuários com uso de procedimentos contábeis fraudulentos. Como resultado a empresa foi condenada a devolver os valores cobrados entre 1990 e 1998. O contrato de Grenoble com a Companhia de Gestão da Água do Sudeste, cuja maioria das ações pertencia ao grupo Suez S.A., foi cancelado e o preço das tarifas, impostas aos usuários, despencaram.

Além da aplicação de altas tarifas por meio de fraudes e corrupção de agentes públicos no caso da atuação do grupo Suez, em Grenoble, também a economia de água era penalizada. Segundo reportagem do Consórcio Internacional de Investigação Jornalística (2003) a empresa foi autorizada a aumentar o preço da água caso o consumo fosse inferior a 12.8 milhões de metros cúbicos por ano, o que em última instância corresponde à negação do discurso neoliberal que defende a que a cobrança pelo consumo de água pela iniciativa privada, poderia contribuir para a redução do consumo.

Além do escândalo em Grenoble, outros se sucederam envolvendo pagamento de dinheiro a representantes do governo por parte de representantes de empresas privadas de saneamento básico, em troca de aprovações de contratos para operação de serviços de saneamento básico. Entre alguns casos podem ser citados os do prefeito de Angouleme, Jean-Michel Boucheron condenado por corrupção relacionado ao grupo Vivendi (atual Veólia) em 1997, o caso do diretor geral da Vivendi Jean-Dominique Deschamps, que foi apanhado pagando comissões ilegais para festa de políticos em troca de obtenção de novos contratos em 1996, entre vários outros, relatados pelo Consórcio Internacional de Investigação Jornalística (2003).

Em relação à experiência inglesa pode-se afirmar que as redes de infra-estrutura remontam o período anterior à Segunda Guerra Mundial, sendo que durante vários anos o Estado por meio de seu governo central teve a competência sobre a gestão da maior parte dos serviços de abastecimento de água. Como estes serviços se encontravam concentrados, quanto à sua gestão, as políticas de subsídios cruzados eram facilitadas entre regiões mais e menos lucrativas. 
Os serviços de coleta de esgotos, segundo Britto (1998, p.182) eram efetuados de forma separada, com a atuação das instâncias municipais e dos sindicatos intermunicipais.

A partir da década de 1970, conforme Britto (1998, p.183) houve reformas no sentido de se obter uma maior concentração e organização dos serviços de saneamento por meio da criação das denominadas "Regional Water Authorities" - RWA. Estas companhias, a princípio, contemplavam a participação de políticos locais nas tomadas de decisão, mas, paulatinamente esta participação foi sendo reduzida e as decisões de investimentos ficaram estritamente nas mãos das equipes técnicas que passaram a optar por grandes obras em detrimento da manutenção dos pequenos sistemas.

Como lembra Britto (1998, p.183), o encarecimento dos sistemas, os investimentos necessários para a continuidade das obras, aliados à política de não financiamento no governo Thatcher induziram à substituição da gestão pública da água pela gestão privada.

Para o caso inglês é importante notar que os serviços de saneamento básico sempre estiveram atrelados ao planejamento e gestão dos recursos hídricos, fato este que se alterou após a privatização das Companhias Regionais (RWA), com a separação do planejamento, gestão e operação dos sistemas.

Deste modo, conforme Britto (1998, p.184) o planejamento das políticas públicas do setor ficou a cargo das denominadas "National Rivers Authority” - NRA - , as denominadas “Water Services Companies” - WSC substituíram as Companhias Regionais na operação e gestão dos sistemas de saneamento e o denominado "Office of Water Services” - OFWAT foi criado com a responsabilidade de regulação e controle da atividade privada no setor.

Conforme observou Britto (1998, p.185-186) a capacidade de regulação dos OFWAT é restrita, em função da limitação dos recursos humanos e financeiros, da dependência das informações fornecidas pelas empresas prestadoras e da restrição de suas funções que inclusive desconsidera a cobrança das empresas à universalização dos serviços.

O resultado disto foi o fim do subsídio cruzado entre locais mais lucrativos e menos lucrativos. Deste modo, houve o abandono das pequenas localidades por parte das empresas privadas, já que estas áreas não eram lucrativas, ocorrendo, consequentemente, a deterioração e queda de qualidade dos serviços. 
Também o interesse das empresas de saneamento básico sempre foi prioritariamente respeitado, com aumento anual de tarifas acima da taxa nacional de inflação, o que levou a Inglaterra em 1999 a alcançar o $4^{\circ}$ lugar entre os países que apresentam as maiores médias nos preços das contas de consumo de água, segundo dados da Organização para a Cooperação Econômica e Desenvolvimento - OCDE ${ }^{32}$.

Estas duas experiências, a francesa e a inglesa, carregam em si modelos de concessões, de gestão e de regulação dos serviços que têm sido exportados para outros países onde os serviços de saneamento básico estão sendo privatizados.

O sucesso ou insucesso da concessão dos serviços à iniciativa privada não depende necessariamente do tipo de modelo adotado, mesmo porque grande parte dos países que tem optado pela privatização dos serviços tem mesclado os dois modelos, a exemplo da Argentina e do Brasil.

O caso da privatização dos serviços de saneamento básico na Argentina é importante ser mencionado, já que é possível reconhecer várias etapas do desenvolvimento do setor.

Britto (1998, p.186-191) em sua retrospectiva sobre a experiência Argentina de privatização, particularmente no caso de Buenos Aires, lembra que até 1980 os serviços de saneamento básico eram responsabilidade de uma autarquia denominada "Obras Sanitárias de la Nation” - OSN, ligada à uma empresa pública nacional, que por sua vez centralizava as decisões de planejamento, com a definição de políticas para o setor, pelo investimento em infra-estrutura e gestão dos serviços.

Os serviços geridos pela instituição pública na década de 40 chegaram a abranger, praticamente, a totalidade da população de Buenos Aires, com tarifas justas e eqüitativas. Mas, com o rápido crescimento urbano e a queda de investimentos os índices de cobertura logo caíram e isto, associado às novas orientações do governo militar na década de 80 , levou à descentralização dos serviços que causou o agravamento ainda maior do quadro do setor.

Com a descentralização houve o fim da possibilidade de subsídio cruzado, repetindo-se o ocorrido no caso inglês, causando o abandono e a queda ainda maior dos investimentos. Aliado a isto, as províncias que receberam a incumbência de gerenciar os serviços de forma descentralizada foram deixadas à própria sorte, sem a devida

\footnotetext{
32 ORGANIZAÇÃO PARA COOPERAÇÃO ECONÔMICA E DESENVOLVIMENTO - OCDE. Household Water Pricing in OECD Countries, Paris- Fr: OECD - Publishing, Maio, 1999.
} 
capacitação para tal função. O resultado foi uma redução, ainda maior, da qualidade dos serviços e das taxas de cobertura no país, como lembra Britto (1998, p.188).

O mau funcionamento dos serviços municipais e das OSN serviu de âncora, por sua vez, ao discurso da incompetência do Estado em gerir os serviços, levando o governo de Carlos Menen, em 1993, a aceitar, com forte influência do Banco Mundial e do FMI a opção pela privatização dos serviços.

A entrada da iniciativa privada no setor de saneamento básico na Argentina se fez via associação entre várias empresas, ou seja, sob a forma de consórcio. Participaram deste consórcio a Lyonnaisse des Eaux (pertencente ao grupo Suez), Sociedade General de Aguas de Barcelona (também com participação acionária da Suez), Generale des Eaux (pertencente ao grupo Veólia), Meller, Banco de Galícia y Buenos Aires, Anglian Water e o Programa de Propriedade Participativa (dos trabalhadores da OSN), conforme relatado por Britto (1998, p.189).

A concessão estabelecida teve prazo estabelecido de 30 anos e foi do tipo não onerosa, ou seja, não houve pagamento pela concessão, com a promessa de redução de tarifas e expansão das redes por parte das empresas prestadoras.

A atuação da concessionária privada, contudo, não surtiu o efeito desejado, havendo aumentos de tarifas constantes e, como a agência reguladora criada não possuía a autonomia necessária, as promessas de investimentos não eram cobradas.

Como exemplo da captura da estrutura reguladora pelo regulado, o ICIJ (2003) constatou que a agência reguladora criada para controlar a “Águas Argentinas”, empresa controlada pelo consórcio supracitado, era por demasiada lenta para aplicação das multas sobre as quebras de contrato sobre investimentos em construção de redes.

Também vários casos de corrupção foram constatados, envolvendo agentes do governo, como o caso da ex-Ministra do Meio Ambiente Maria Júlia Alsogaray, que enriqueceu ilicitamente após ter permitido a Águas Argentinas inúmeros aumentos de tarifas mesmo frente a um quadro de crises econômicas que levaram ao empobrecimento ainda maior de grande parte da população no início de 2000.

A crise econômica estabelecida não teria atingido somente a população, causando queda no poder aquisitivo e na capacidade de pagamento pelos serviços, mas influenciou a baixa dos lucros da empresa.

Esta baixa de lucros resultou em paralisação de investimentos que levou ao acúmulo de milhões em dívidas advindas de multas, que o novo governo de Eduardo Duhalde procurou cobrar. Contudo, mais uma vez, a estreita ligação política e a 
influência dos grandes grupos junto às agências multilaterais reverteram em vantagens para os grupos privados.

Em 2002 o Fundo Monetário Internacional pressionou o governo a autorizar o aumento de tarifas como condição para a renegociação da dívida, resultando em um aumento de $10 \%$ nas tarifas em favor da Águas Argentinas, como destacado pelo Consórcio Internacional de Investigação Jornalística (2003).

Para aquelas milhões de pessoas que ficaram de fora da cobertura dos serviços o aumento em nada alterou, já que o aumento não resultou em extensão das redes. Para aqueles que já se encontravam na linha de pobreza ou que mantinham seus pequenos negócios o aumento de 10 por cento representou a falência.

É importante lembrar que até 1997 a Águas Argentinas teria construído somente um terço das estações de bombeamento e investido somente $19 \%$ do montante prometido em rede de esgotos. Ainda, além da continuidade dos déficits de atendimento e de investimentos, no início dos anos 2000 foi detectado alto teor de nitrato em vários pontos da rede de distribuição de água, principalmente em áreas de predomínio de população mais empobrecida, sendo que em parte isto se deveu a reutilização, pela empresa, de poços já contaminados.

Em 2003, Nestor Kirchner assumiu o posto de Presidente da República e aparentemente, as relações com o grupo Suez, que neste período controlavam a Águas Argentinas com 39,93\% das ações, endureceram. Isto refletiu na ameaça, em 2005, do grupo Suez S.A. em se retirar dos serviços de saneamento da Argentina, bem como de nova utilização de artifícios políticos para conseguir aumentos de tarifas, envolvendo o então o governo francês nas formas de pressões já adotadas. O resultado disto foi a decisão do governo Kirchner, em 2006, de rescisão do contrato com a “Águas Argentinas".

A nova reestruturação do setor na Argentina inclui novamente o Estado como responsável pelo planejamento e investimentos em infra-estrutura, tendo sido criada a empresa “Águas e Saneamento Argentinos - AySa como sociedade anônima, na qual 90\% das ações são do Estado e 10\% dos trabalhadores.

Deve-se destacar que no comando da nova empresa foram chamados indivíduos que participaram no passado, da privatização dos serviços, o que tem sido alvo de críticas, conforme observado por Gentili (2006).

A experiência argentina mostra, claramente, a importância das articulações políticas nos resultados das diretrizes impostas. A participação social só aparece e na 
escolha do novo governo, no início da década de 2000, que provavelmente respaldou as novas decisões. Contudo, ainda restam muitas questões a serem solucionadas, tais como sobre as fontes de financiamento para o setor, como possibilitar os subsídios cruzados já que a operação dos serviços e encontra descentralizada, como garantir a participação popular nas decisões, já que os interesses privados continuam mobilizados, etc. Enfim, resta saber se a sociedade argentina continuará a cobrar resultados que façam frente às suas necessidades no setor não somente por meio das eleições, mas por meio da criação de instâncias de participação que permitam a manifestação de suas reivindicações.

Também foram divulgadas outras experiências de privatização no setor de saneamento básico no âmbito internacional que resultaram em ampliação dos déficits ou em exclusão do acesso à população mais empobrecida, tais como o caso de El Alto na Bolívia, Atlanta nos EUA e na Costa dos Golfinhos na África do Sul.

No caso de El Alto, na Bolívia, conforme Santana (2005), o contrato com a concessionária Águas de Illimani ligada ao grupo Suez S.A., foi rescindido em 2005 devido ao não cumprimento das metas contratuais e por abuso nos preços das tarifas, as quais foram atreladas ao dólar e aplicadas aos usuários com parcos recursos econômicos.

No caso de Atlanta - EUA, a empresa United Waters, ligada ao grupo Suez S.A., que obteve a concessão pelos serviços em 1999, também manteve constantes os aumentos de tarifas, sem a respectiva melhoria dos sistemas de água, obrigando a população a racionar água e a fervê-la devido à sua má qualidade. A empresa, por sua vez, buscou se justificar culpando a precária estrutura de saneamento recebida e a falta de informação sobre este fato no ato da concessão. Segundo o jornal Clarin (2005) os problemas com a concessionária viriam a provocar diversas denúncias dos usuários as quais induziram o rompimento do contrato em 2003.

O caso africano de privatização trouxe conseqüências ainda piores para a população que dependia do abastecimento de água. A água que antes era oferecida gratuitamente, a partir de 1999 passou a ser cobrada por concessionárias privadas, como observado por Loftus (2006) alterando o ritmo de vida das comunidades envolvidas. Conforme o Consórcio Internacional de Investigação Jornalística (2003), o custo das tarifas chegava a comprometer $40 \%$ da renda familiar média na África do Sul obrigando muitas famílias que tiveram sua água cortada a procurar outras fontes, as quais estavam contaminadas. O resultado disto foi a ocorrência de um grande surto de cólera que terminou em 2002 com mais de 250 mil pessoas contaminadas e 300 mortes. 
As experiências internacionais mostram que os modelos francês e britânico foram exportados, graças ao fortalecimento do poder de atuação de alguns grupos econômicos privados, a princípio no mercado interno. À medida em que foram conquistando mais espaço na atuação interna, também foram centralizando suas atividades e criando lobbies com as instâncias políticas, o que permitiu, paralelamente à liberalização financeira, a expansão de suas atividades no exterior.

Foi possível compreender que a conquista do mercado interno pela iniciativa privada no caso francês e britânico, foi amparada fortemente pelas políticas públicas desenvolvidas pelos respectivos governos, que apoiaram também, juntamente com as agências multilaterais, a expansão das fronteiras de atuação em territórios estrangeiros.

Portanto, a expansão francesa e britânica, cuja representação privada atua no setor de saneamento básico, esteve sustentada nas políticas de liberalização e desregulamentação financeira e receberam grande apoio do Banco Mundial e do Fundo Monetário Internacional, que por meio de pressões promoveram a inserção dos grandes grupos privados do setor em países financeiramente dependentes.

Vale lembrar que a própria privatização do mercado interno francês e britânico foi problemática, gerando conflitos em relação ao atendimento, devido aos custos repassados aos usuários, devido à retração da capacidade de subsídio cruzado e mesmo em relação à qualidade dos serviços oferecidos, sem falar nos casos de corrupção citados. Os problemas só conseguiram ser superados devido a forte participação da sociedade civil e a cobrança dos usuários, provocando, consequentemente, a alteração da dinâmica de atuação das empresas no âmbito interno.

Mesmo sendo questionada do ponto de vista das falhas existentes, a privatização dos serviços de saneamento básico começou a ser adotada por vários países, com o uso dos modelos francês e britânico, principalmente.

Isto se deve em grande parte à abertura dos mercados, ao desenvolvimento das políticas neoliberais e à pressão das agências multilaterais sobre os Estados dependentes para aplicação de políticas de privatização.

As fragilidades dos Estados e a fraca organização social encontradas em grande parte dos países dependentes não somente contribui para facilitar a penetração destes grandes grupos transnacionais, mas também para perpetuar as estratégias de ampliação da reprodução do capital destes mesmos grupos. 


\subsection{A experiência brasileira - $O$ caso da Suez S.A.}

A atuação privada no setor de saneamento básico no Brasil não é recente. Segundo Rocha (1997) esta atuação já ocorreu no passado, quando se estruturaram as primeiras redes, a exemplo da Cia Cantareira em São Paulo.

Contudo, as primeiras obras relacionadas ao abastecimento de água no Brasil estão associadas à instância pública de gestão urbana que em 1561 explorou o primeiro poço artesiano e, em 1673 efetuou obras de adução de água com a inauguração de um aqueduto que possibilitava a utilização de um chafariz central na cidade do Rio de Janeiro.

Em 1744 o primeiro chafariz foi inaugurado, também, em São Paulo e, em 1842, segundo Rocha (1997, p.17) já havia 4 chafarizes na mesma cidade. Nessa época o uso de chafarizes era o sistema possível para facilitar a obtenção de água nas áreas onde a ocupação urbana já inviabilizava, de certo modo, o uso de poços.

Com a evolução da demanda, não somente doméstica, mas principalmente industrial, houve necessidade de se desenvolver o sistema de abastecimento de água. Deste modo, entre 1857 e 1877, conforme Rocha (1999, p.17-18) foi firmada parceria entre o Governo do Estado e a empresa “Achilles Martins D’Éstudens” que construiu o primeiro sistema de abastecimento para a cidade de São Paulo, denominado "Sistema Cantareira de Abastecimento de Água”. Este sistema de parceria pode-se afirmar, foi a primeira forma de privatização adotada no setor.

O aumento constante da demanda, aliado à incapacidade de continuidade de investimentos por parte da empresa, levou à administração pública a encampar, em 1892, a denominada "Companhia Cantareira”.

É possível afirmar, deste modo, que a iniciativa privada naquele período não obteve sucesso na continuidade da prestação dos serviços.

Somente na década de 1930 é que se constituiu a regulação do setor de saneamento básico no Brasil, a partir do “Código das Águas”. Neste período, os aparatos de regulação estavam alinhados aos princípios centralizadores do Estado Novo e à constituição de infra-estrutura que permitiria o desenvolvimento da indústria e também o atendimento das demandas de saneamento básico por parte da população.

Como lembra Britto (2001, p.1082) o Código das Águas, contribuiu fortemente como modelo de regulação econômica quanto aos serviços públicos, com a instituição da taxa de retorno. Por meio dessa taxa poderia ser alcançado o equilíbrio financeiro dos investimentos. Esta taxa de retorno quanto aos investimentos, no entanto, não poderia 
ultrapassar os $12 \%$ ao ano, o que vislumbrava a tentativa de controle de possíveis abusos.

As subseqüentes Constituições de 1934 e de 1946 também trazem à tona a possibilidade de atuação das instituições municipais na gestão dos serviços públicos no âmbito local, como aponta Britto (2001, p.1082). Isto contribuiu, segundo a mesma autora (2001, p.1084), para o fortalecimento das autarquias municipais que concorreriam mais tarde, na década de 60, com as empresas de gestão estadual também denominadas de companhias estaduais.

É importante destacar que a titularidade pela prestação dos serviços foi especificada constitucionalmente como sendo de âmbito do poder municipal, o que levou a necessidade da exigência de contratos de concessão às empresas estaduais. Deste modo, os municípios que não possuíam condições técnicas ou financeiras de desenvolver os serviços de saneamento básico podiam optar pela concessão dos serviços à empresa estatal correspondente.

De acordo com Britto (2001, p.1084) o início da ditadura militar foi seguido da tentativa de reestruturação do setor de saneamento por meio da criação do Sistema Financeiro de Saneamento- SFS -, ligado ao Sistema Financeiro da Habitação - SFH -, que era viabilizado por meio de recursos do Fundo de Garantia por Tempo de ServiçoFGTS.

Deste modo, foram criadas e fortalecidas as companhias estaduais que eram beneficiadas com o sistema de financiamento. Os municípios, por sua vez, só poderiam ter acesso a estes financiamentos por meio da concessão dos serviços a essas companhias estaduais, o que enfraqueceu o poder de barganha dos municípios e, criou a médio prazo um distanciamento das decisões das companhias estaduais em relação às necessidades locais, especialmente no que concerne àquelas localidades distantes das áreas economicamente mais dinâmicas. Cabe destacar, que apesar da forte pressão para que os municípios concedessem a operação dos serviços às companhias estaduais, não foram todos que aceitaram essa condição, mantendo os serviços totalmente sob responsabilidade municipal, por meio da resolução dos problemas financeiros de outras formas.

No que concerne à atuação das companhias estaduais, Britto (2001, p.1086) ressalta que os investimentos em abastecimento de água foram priorizados em detrimento da coleta e tratamento de esgotos. Os déficits em coleta e tratamento de 
esgotos acumulados nestes últimos, hoje comprometem a qualidade e o custo do tratamento de água para fins de abastecimento, conforme expõe Viveiros (2004).

Além do abandono de partes essenciais dos serviços, também a abrangência do Plano Nacional de Saneamento - PLANASA quanto à possibilidade de subsídios cruzados teria sido limitada. O motivo disto, como infere Fabriani e Pereira (1987), está fundamentado na concentração de renda da população brasileira, já que a maioria estaria incapacitada de arcar com os preços reais dos serviços prestados para a manutenção do sistema.

A extinção do Banco Nacional da Habitação que era coordenado pelo PLANASA, em 1986, aliado as sucessivas crises econômicas, com o crescimento do desemprego e a diminuição dos volumes arrecadados pelo FGTS, desestruturou as vias de financiamento pelo Estado e a possibilidade de investimentos das empresas estaduais. Isto resultou em aumento das demandas sem acompanhamento de expansão dos serviços em grande parte do território brasileiro.

Segundo Silva (1999, p.271) houve grande evolução na cobertura de abastecimento de água entre os finais da década de 60 e a década de 80 . Mas, apesar da continuidade do crescimento, o ritmo de cobertura não se manteve, conforme ilustra o gráfico a seguir.

\section{Gráfico 7}

Brasil - Evolução da Cobertura de Abastecimento de Água

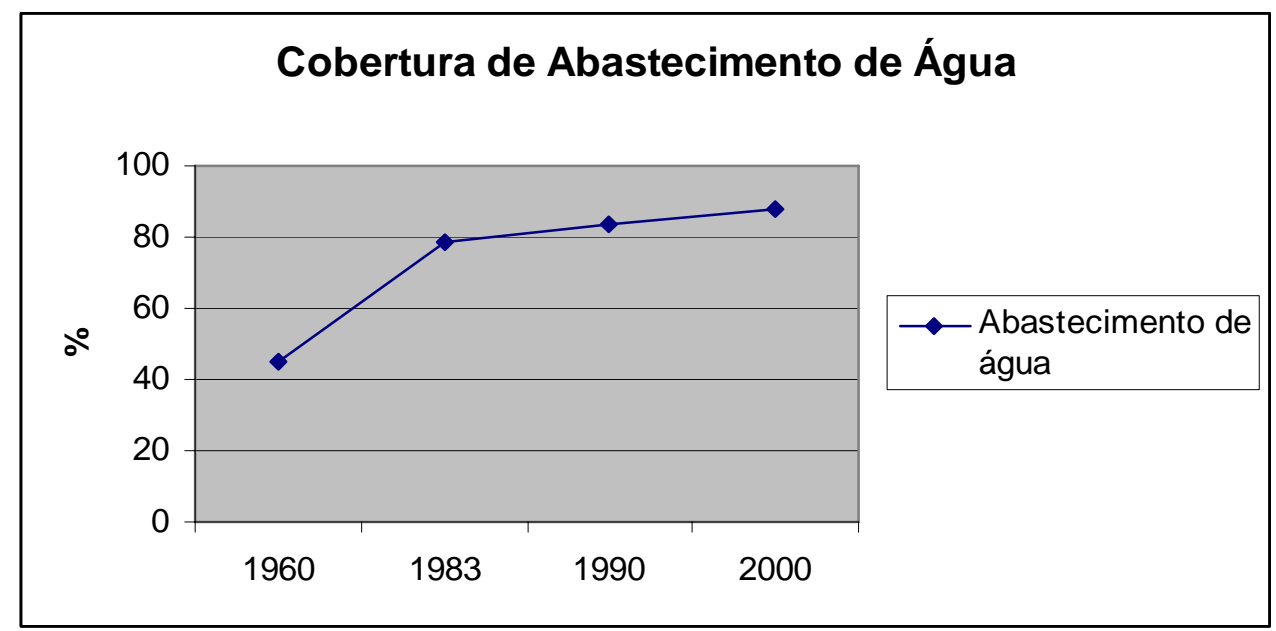

Fonte de dados: Infurb-USP/1995, ABES e IBGE/2000 
Com base nos dados do IBGE ${ }^{33}$ pudemos constatar que em 2000, cerca de 88\% da população brasileira residente na área urbana era atendida por abastecimento de água em rede e cerca de $46 \%$ possuía coleta de esgotos.

Em relação aos investimentos em coleta de esgotos Silva (1999, p. 271) lembra que o crescimento foi muito inferior ao do abastecimento de água e, podemos completar assinalando que menor ainda foram os índices relativos ao tratamento dos esgotos, o que implica em comprometimento dos cursos d’água onde os esgotos in natura são lançados.

Enquanto o sistema de saneamento se esfacelava e enfraqueciam as empresas estaduais, os municípios que não tinham concedido os serviços às empresas estaduais procuravam se organizar de forma que pudessem recuperar sua autonomia, buscando um re-equilíbrio do setor. Neste sentido, algumas ações refletem este movimento, como a criação da Associação de Serviços Municipais de Água e Esgotos - ASSEMAE, conforme citado por Brito (2001, p.1087) que no início da década de 1990, junto com a Associação Brasileira de Engenharia Sanitária - ABES, propuseram o Projeto de Lei n.199, que reorganizaria o setor com base no controle social. Este projeto, porém, foi vetado pelo Presidente Fernando Henrique Cardoso em 1994, já que as políticas neoliberais em prol da privatização do setor já estavam sendo elaboradas.

Deste modo, apesar da constituição de 1988 ter voltado a afirmar a competência concorrente dos municípios no setor de saneamento básico, os governos que se sucederam na década de 1990 procuraram atender às exigências impostas pelo FMI que apontavam a necessidade de redução de gastos públicos, dando margem a abertura à privatização do setor de saneamento básico.

Em 1990, o governo Collor com o propósito de reerguer o setor de saneamento básico, criou o Programa de Modernização do Setor de Saneamento - PMSS. Este programa que previa a obtenção de recursos para investimento por meio do Banco Mundial, permitiu o avanço das diretrizes desta agência multilateral na formulação das novas políticas do setor.

No segundo mandato de Fernando Henrique Cardoso, como lembra Britto (2001, p.1090) a proposta de privatização que antes era facultativo se transformou praticamente

\footnotetext{
${ }^{33}$ IBGE - Instituto Brasileiro de Geografia e Estatística. SIDRA/Dados Demográficos.2000. Disponível em: http://www.sidra.ibge.gov.br/> Acesso em 02/03/06.
} 
em uma diretiva e o financiamento para investimentos no setor só passou a ser acessível à iniciativa privada.

É interessante notar que como parte do acordo de ajuste econômico imposto pelo FMI o governo federal lançou a Resolução n. 2421/98 do Conselho Monetário Nacional, que segundo Brito:

(...) vedava a órgãos públicos as contratações de novos financiamentos em saneamento junto ao Fundo, mesmo que estes órgãos públicos comprovassem condições econômicas e financeiras que assegurassem a capacidade de pagamento dos empréstimos pretendidos. ${ }^{34}$

Torna-se claras as condições que permitiram e reforçaram a privatização dos serviços de água no Brasil e a partir destas condições é que os grupos transnacionais se lançam para a obtenção de pontos estratégicos para a reprodução do capital. Como são estes grupos que detém maior poder econômico e forte influência política foram eles que se inseriram nas principais cidades concedidas, ao exemplo do grupo Suez S.A.

Em relação ao avanço da privatização em grandes aglomerações urbanas, podese dizer que as empresas ligadas aos grandes grupos privados levam vantagens na concorrência das concessões, como afirmado por Carlos Henrique da Cruz Lima, representante da empresa Developer, em entrevista ao Jornal Gazeta Mercantil ${ }^{35}$. Estas vantagens se referem principalmente ao potencial de investimento que estes grupos transnacionais representam para as instâncias que concedem os serviços.

Entre os grupos privados que atuam no Brasil desde a década de 1990, os grupos franceses Suez S.A. e Veólia Environment são aqueles que obtiveram concessões de grandes cidades, como Manaus, Campo Grande e Curitiba, além de, também, atuarem em médias e pequenas cidades, como Limeira - SP (concedida à subsidiária do grupo Suez S.A.) e em várias outras do interior do Paraná, por meio da atuação da SANEPAR S.A. que se constituíu por capital público e por capital privado, com participação acionária da empresa Dominó Holdings S.A. (que tornou-se sócia do grupo Veólia em 1998).

\footnotetext{
${ }^{34}$ BRITTO, A.L. A regulação dos serviços de saneamento no Brasil: Perspectiva histórica, contexto atual e novas exigências de uma regulação pública. In: Anais do IX Encontro Nacional da ANPUR - Ética, Planejamento e Construção Democrática do Espaço. Rio de Janeiro: APPUR, 2001, p. 1090.

${ }^{35}$ GAZETA MERCANTIL. A disputa pelo lucrativo negócio da água. 06/02/2002.
} 
Como já relatado, o grupo Suez S.A. atua em Manaus por meio da sua subsidiária DRMA Participações e Empreendimentos S.A., em Campo Grande atuou via Agbar, tendo se desligado dos serviços em 2005 e, em Limeira vem atuando por meio das subsidiárias Lumina Engenharia Ambiental Ltda. (anteriormente CBPO Engenharia Ltda) e Suez Environment S.A. (anteriormente Ondeo Services S.A.).

Os pontos em comum na atuação destes grandes grupos em território brasileiro, no que concerne ao saneamento básico são a localização geográfica em áreas de grande ocorrência de água e o alinhamento às políticas de saneamento básico do governo federal no que se refere à opção pela privatização.

A seguir procuramos contemplar um maior detalhamento sobre as duas áreas brasileiras cujos serviços de saneamento básico foram concedidos a empresas ligadas ao grupo Suez S.A.

O município de Limeira está inserido na Bacia Hidrográfica do Paraná e em área de recarga (próximo à área de afloramento) do Aqüífero Guarani, cuja produção hídrica é uma das maiores do mundo. O primeiro mapa apresentado procura contemplar esta área.

A seguir a imagem de satélite procura ilustrar a posição privilegiada do município de Manaus junto ao rio Negro, o principal afluente do rio Amazonas. 
Mapa 2

Limeira na área de recarga do Aqüífero Guarani

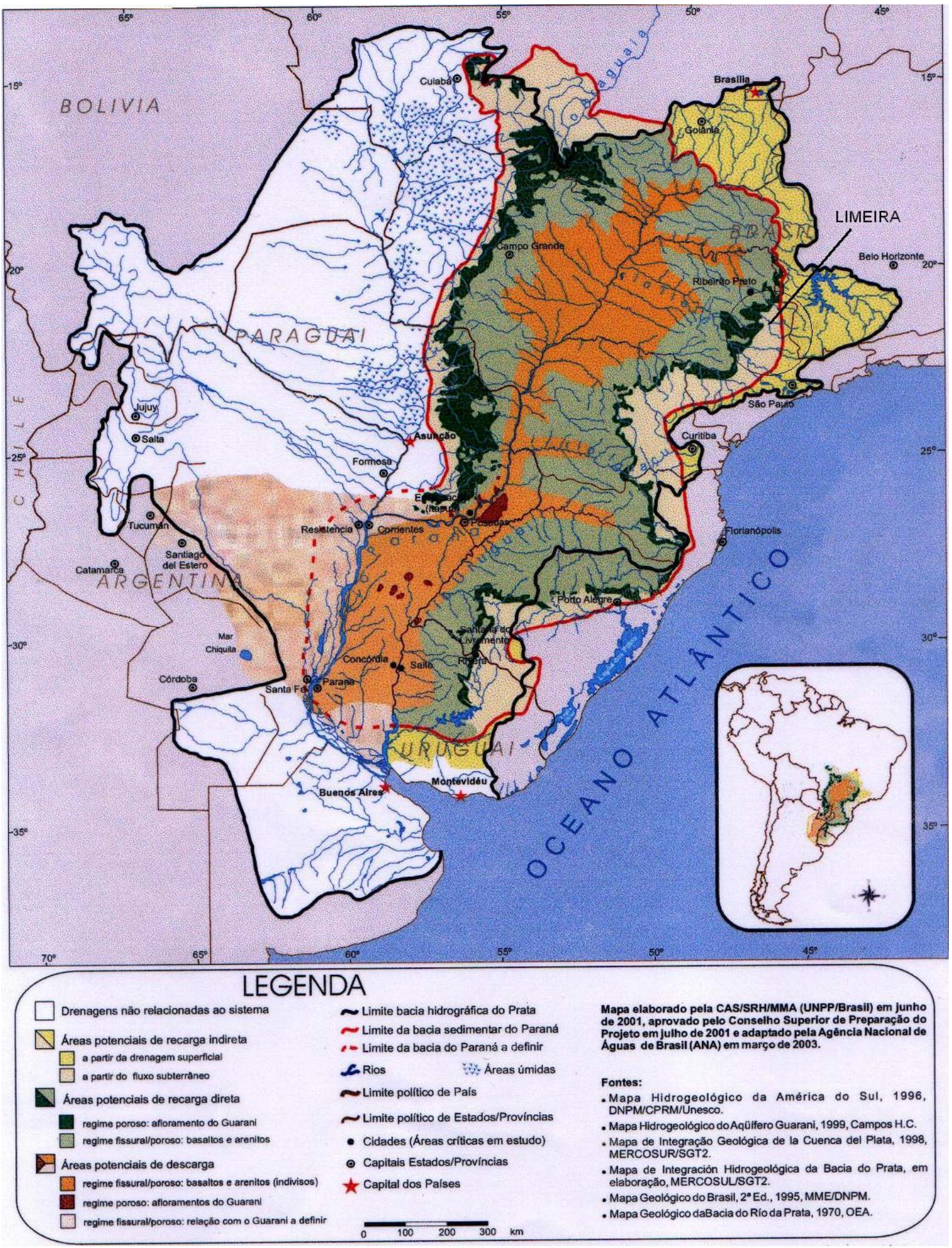

Fonte: Elaboração pela CAS/SRH/MMA, junho de 2001. Disponível em < http://www.ana.gov.br/guarani/files/mapaA4.pdf > Acesso em janeiro/2003. Adaptação: Cristiane F. de Oliveira 


\section{Imagem 1}

Manaus às margens do Rio Negro

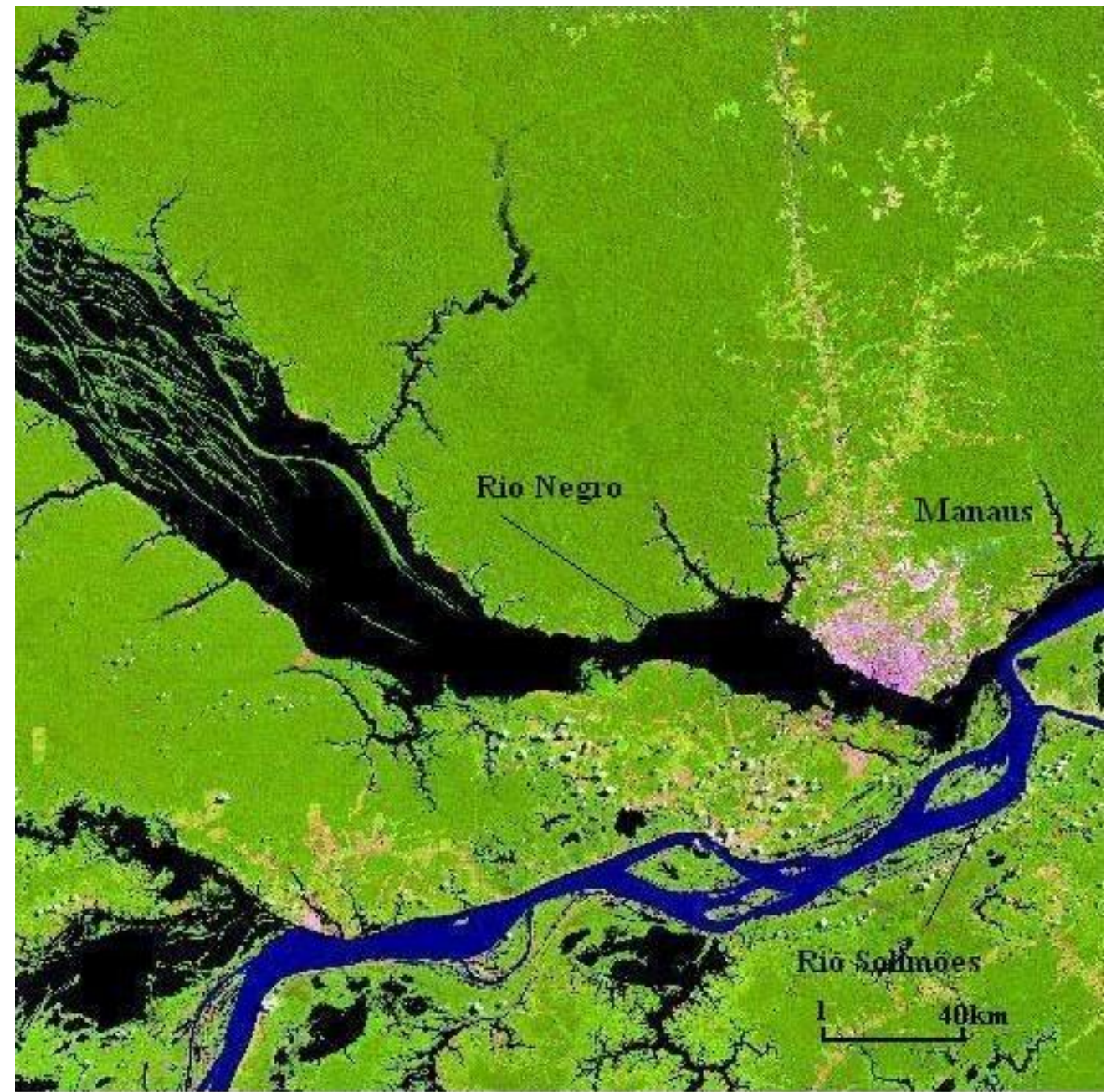

Fonte: INPE - Data da aquisição da imagem 15/08/1988

Conposição colorida bandas $3 / 4 / 5$

Satélite Landsat - 5 TM

Nota-se que as duas áreas concedidas ao grupo Suez S.A. no Brasil para prestação de serviços de saneamento básico possuem grandes potencialidades de obtenção de água.

O modelo de concessão adotado para os casos estudados de Manaus - AM e Limeira - SP foi o francês, na qual a empresa fica responsável pela administração e operação dos serviços, bem como pela manutenção e investimentos por um prazo determinado.

É importante lembrar que a posse dos ativos, ou seja, da infra-estrutura, continua sendo do Estado, por meio de suas instâncias de governo municipais, já que são estas 
que detém a titularidade dos serviços. Deste modo, o concedente, representado pelo governo municipal em Limeira e em Manaus, delegou a operação dos serviços pelo prazo de 30 anos, com a garantia de que a empresa pudesse obter o equilíbrio econômico e financeiro e com a garantia de haver ressarcimento de custos não amortizados, em caso de rescisão do contrato antes do prazo estipulado.

Quanto ao sistema regulador, como não havia experiência pretérita por parte dos governos envolvidos e nem da efetiva participação da sociedade nas decisões, como ocorre no caso francês, foi adotado o modelo britânico, na qual foram nomeadas agências responsáveis pela fiscalização e controle específicas para cada caso.

No caso de Limeira a antiga autarquia que operava os serviços de saneamento básico o "Serviço Autônomo de Água e Esgoto" - SAAE passou a assumir as funções de órgão fiscalizador, como lembra Vargas e Lima (2004, p.78). Para o caso de Manaus foi criada pela Lei n. 2568/99 a Agência Reguladora dos Serviços Públicos Concedidos do Estado do Amazonas - ARSAM, com o intuito de regular, controlar e fiscalizar os serviços concedidos.

Os contratos de concessão foram firmados sem o apoio de um marco regulatório específico para o setor, já que este ainda não havia sido criado. Os termos firmados, portanto, procuram refletir os interesses do concedente e da concessionária e, de forma geral, resgatam alguns princípios básicos dos serviços públicos, como o da universalização que pressupõe os serviços sejam acessíveis à todos igualmente, de modicidade que se refere à aplicação de tarifas que possam ser acessíveis por parte do usuário, de continuidade dos serviços, de qualidade do atendimento, de eficiência e cortesia.

No entanto, como a sociedade civil nos dois municípios tratados ainda não está organizada de tal forma a fazer valer seus direitos por meio da cobrança destes princípios básicos, a responsabilidade recai sobre as agências reguladoras criadas. Deste modo, a cobrança dos termos firmados no contrato é responsabilidade das agências reguladoras de Limeira (SAAE) e de Manaus (ARSAM) que por sua vez, não alcançaram autonomia suficiente quanto ao aspecto econômico, técnico e mesmo político, apresentando-se frágil e dependente frente ao poder econômico e influência política das concessionárias. Estes fatos têm levado a captura do regulador pelo regulado e ao comprometimento do cumprimento das metas contratuais firmadas.

Vargas e Lima (2003, 76) lembram ainda, que há vantagens e riscos envolvidos no processo de privatização dos serviços. 
Entre as vantagens relacionadas à privatização dos serviços são citadas: o estímulo à competitividade por parte das empresas públicas, e quanto a isto se pressupõe que as empresas privadas apresentariam padrões de desenvolvimento superiores e a possibilidade de transferência de tecnologia avançada para o setor.

Como após a Resolução n.2421 de 1998 do Conselho Monetário Nacional o financiamento dos investimentos em saneamento básico só poderia ser viabilizado por meio de instâncias privadas, a privatização passou a ser vista como solução econômica e também passou a ser relacionada às vantagens no que diz respeito à possibilidade de desoneração do poder público.

Com relação à possibilidade de financiamentos as empresas concessionárias aproveitaram a oportunidade e, a exemplo da Águas do Amazonas, o Banco Nacional de Desenvolvimento Econômico e Social - BNDES proporcionou em 2003 um financiamento de R\$ 65,7 milhões. Segundo o BNDES o financiamento apoiou um projeto que previa cobertura de abastecimento de água em Manaus de 95,1\% da população.

Assim, com orçamento de $\mathrm{R} \$ 112,4$ milhões, em 2003, incorporado o financiamento do BNDES, o projeto previa várias outras ações, dentre elas:

(...) a reforma e a melhoria da infra-estrutura das estações de tratamento de água dos sistemas Ponta de Ismael, localizado na Zona Oeste da cidade, e Mauazinho, na zona Leste; reabilitação e extensão das redes de água e esgoto; além da recuperação e ampliação das estações de bombeamento e reserva, e das estações elevatórias e de tratamento isolado ${ }^{36}$

A possibilidade de obtenção de financiamentos é um dos grandes pilares de estímulos aos grupos transnacionais do setor de saneamento básico. Deste modo, como destaca o Consórcio Internacional de Investigação Jornalística - ICIJ “alguns países não estão mais, definitivamente na agenda da privatização”, como as concessões no Sul da África, “a menos que o Banco Mundial ou outras instituições financiem os custos de investimento"37. Enquanto isso, os EUA, o Leste Europeu e a China, se inserem na

\footnotetext{
${ }^{36}$ BANCO NACIONAL DE DESENVOLVIMENTO ECONÔMICO E SOCIAL - BNDES. BNDES financia expansão da rede de água e esgoto de Manaus. 03/01/03. Disponível em: $<$ http://www.bndes.gov.br/noticias/not574.asp > Acesso em 26/03/03.

${ }^{37}$ CONSÓRCIO INTERNACIONAL DE INVESTIGAÇÃO JORNALÍSTICA - ICIJ.Cholera and the Age of the Water Barons. 2003.2 Disponível em: $<$ http://www.icij.org/dtweb/water/PrintReady.aspx?AID=1 > Acesso em 04/06/03.
} 
agenda da privatização devido à abertura dos mercados e da promessa de investimentos por parte do Banco Mundial.

Fica claro que, além dos financiamentos propriamente ditos, proporcionados pelas agências multilaterais, há, também, grande expectativa de crescimento econômico nos países assinalados, com a atração de novos investimentos de capitais e consequentemente de implementação das demandas por serviços, o que potencializa o aumento dos lucros.

Para o caso brasileiro o financiamento de investimentos pelo BNDES tem a mesma conotação já que possibilitou a obtenção de grandes somas de dinheiro subsidiadas pelo Estado.

A possibilidade de captação de financiamentos dos investimentos em saneamento básico, por parte dos grandes grupos econômicos que atuam no setor aparece como uma vantagem. Contudo, esta vantagem para os grupos pode estar estreitamente relacionada a riscos para a sociedade. Neste sentido, de acordo com Silva e Britto (2002) apud Vargas e Lima (2004) entre os riscos enumerados do envolvimento da iniciativa privada no setor de saneamento básico constam o risco de abandono dos direitos sociais em função da priorização do atendimento dos interesses econômicos do mercado.

Deste modo, dentro de uma perspectiva de mercado e empresarial, devido à inviabilidade de obtenção do retorno econômico satisfatório, as populações mais empobrecidas e as áreas menos densas ou periféricas correm riscos de serem relegadas ao segundo plano ou, simplesmente, abandonadas. Ainda, como lembra Silva (1999, p.308), não se pode também ignorar o risco de priorização do atendimento das demandas dos grandes consumidores privados, ao exemplo do setor industrial, em detrimento das demandas públicas para uso doméstico.

Dadas as características estratégicas das redes de infra-estrutura, que permitem o desenvolvimento econômico nacional e o caráter de monopólio natural que a água possui, o poder concedido às empresas é por demasiado preocupante, em especial aos grandes grupos econômicos transnacionais, já que estão em jogo também interesses econômicos internacionais que procuram manter o quadro de dependência dos países mais pobres.

Para isto, como ressalta Sodré (1999, p.73) a pressão por parte destes grupos sob o Estado, a fim de que este intervenha em seu favor, não responde somente aos 
interesses econômicos estritamente particulares à empresa, mas também simboliza um triunfo sobre a economia nacional.

Como forma de evitar as incertezas das negociações e sobrepujar a concorrência, os grandes grupos criam mercados cativos para as empresas coligadas, consumando a integração vertical dos fluxos de capitais. Este fato eliminaria a possibilidade de atuação de empresas que não fazem parte do grupo, que em grande parte são de origem nacional, o que segundo Sanchez (2001, p.5) explicaria a resistência dos empresários nacionais à privatização.

Deste modo a regulação toma importância crucial no desenvolvimento das políticas públicas para o setor já que é ela que deve ditar as regras de atuação dos atores envolvidos, ou seja, das agências reguladoras criadas, das empresas e dos consumidores.

A regulação da atuação privada no Brasil tomou por base, durante muito tempo, a legislação instituída na década de 1930, ou seja, o Código das Águas, que procurava regular a exploração dos recursos hídricos, mas cujo enfoque se voltava para o setor energético.

Na década de 1990 é que vão se delinear as novas propostas de regulação, sendo que no governo de Fernando Henrique Cardoso, em 1995, foi promulgada a Lei n.8.987 que trata das concessões dos serviços de saneamento básico à iniciativa privada. Esta Lei procurou, segundo Vargas e Lima, regulamentar o artigo 175 da Constituição Federal de 1988, “dispondo sobre a prestação de serviços públicos em regime de concessão e permissão" ${ }^{38}$.

Deste modo, todos os contratos que definissem concessões dos serviços à iniciativa privada, a partir de 1995, deveriam se remeter a esta Lei de concessões e também aos princípios estabelecidos pelo PMSS que previam a universalização dos serviços.

Para que isto fosse possível, o PMSS previa a criação de um novo marco regulatório para o setor, que deveria resolver questões pendentes como a da titularidade dos serviços, que continuava a entravar a concessão dos serviços à iniciativa privada em grandes cidades.

Em 2001, como lembra Vargas e Lima (2004, p.74) houve tentativa do governo federal em lançar o Projeto de Lei n.4147 que permitiria a transferência da titularidade dos serviços em regiões metropolitanas à instância de governo estadual e traria algumas

\footnotetext{
38 VARGAS, M.C.;LIMA, R.F.de. Concessões Privadas de Saneamento no Brasil: Bom negócio para quem? In: Ambiente \& Sociedade - Vol. VII n.2 jul./dez/2004. p.73.
} 
outras inovações. Isto resultaria na submissão obrigatória de todos os municípios inseridos em regiões metropolitanas a uma só instância, que a princípio seria a instância de governo estadual. Estas inovações apresentaram-se com o objetivo de fortalecer a estrutura reguladora e garantir a universalização dos serviços por meio da cobrança de uma porcentagem obtida das receitas das concessionárias.

Entretanto, apesar da centralização dos serviços possibilitar a implementação de políticas de subsídio cruzado entre municípios com maior capacidade de pagamento e aqueles com menor capacidade e, com isto proporcionar o alcance da universalização, as argumentações não se referiam a este aspecto, mas sim ao de proporcionar o fortalecimento da estrutura reguladora. A estrutura reguladora por sua vez, não depende necessariamente da centralização dos serviços, bem como a universalização dos serviços não seriam garantidos unicamente com a instituição de uma taxa compulsória.

No que se refere à privatização o projeto de Lei 4147 indicava que as negociações quanto à privatização dos serviços de saneamento básico em regiões metropolitanas envolveriam somente duas partes, o governo estadual e a iniciativa privada, retirando de cena, a diversidade de interesses que os vários governos municipais representavam. Assim, a privatização ou não dos serviços em regiões metropolitanas, dependeria da força das instâncias estaduais, quanto a sua capacidade econômica e administrativa bem como, dependeria do alinhamento político destas instâncias às políticas econômicas neoliberais.

Contudo, não é possível saber se a aprovação do Projeto de Lei 4147 teria modificado o quadro atual dos serviços de saneamento básico, já que como lembra Vargas e Lima (2004, p.75) o Ministro das Cidades, Olívio Dutra, determinou a sua retirada do Congresso.

O que deve ser destacado sobre a tentativa de aprovação deste projeto é que mais uma vez as instâncias locais de decisão seriam excluídas quanto à defesa de seus interesses e, ainda haveria a cobrança de uma taxa compulsória para a garantia de realização de uma tarefa que na verdade é um pressuposto fundamental na prestação dos serviços de saneamento básico. De certo modo, corria-se o risco da taxa compulsória isentar a concessionária dos serviços de buscar soluções para o alcance da universalidade.

Como a universalização dos serviços de saneamento básico depende de investimentos em expansão e manutenção das redes e o Estado está impossibilitado, na conjuntura atual, de arcar sozinho com o ônus destes investimentos, a alternativa 
encontrada foi a da opção pela privatização. Ao se vislumbrar a possibilidade de captação de investimentos que viabilizassem a universalização dos serviços de saneamento básico pela via da privatização, se pressupõe que a iniciativa privada, que se dispõe a atuar no setor, seja capaz de arcar com este investimento, sem que haja necessidade de adoção de medidas compulsórias para tanto.

Por outro lado, buscando garantir o cumprimento dos princípios estabelecidos para os serviços públicos essenciais, que são o de universalidade, de regularidade, de eficiência, de cortesia e de modicidade nas tarifas é que se faz necessário o fortalecimento de instâncias de controle e fiscalização.

O fortalecimento das instâncias de controle e fiscalização é possível com a criação de agências de regulação, dentro da perspectiva de um marco regulatório que possa garantir sua autonomia, procurando evitar, deste modo um dos riscos observado por Vargas e Lima (2004), que é o de captura das instâncias reguladoras por parte do regulado.

Também, conforme Vargas e Lima (2004, p.75), a qualificação técnica, bem como a autonomia decisória e financeira são pré-requisitos que poderiam contribuir para a eficiência das instâncias reguladoras.

Voltando aos instrumentos de regulação, é possível afirmar que o governo de Luis Inácio Lula da Silva conteve, deliberadamente ou não, o avanço das políticas de incentivo à expansão da via privada em grandes cidades, devido à retirada do Projeto de Lei 4147/2001.

Contudo, em meados de 2006, voltou a ser cogitada a necessidade de criação de um marco regulatório que pudesse definir mais claramente as regras de atuação dos atores públicos e privados no setor de saneamento básico. Isto deu origem ao Projeto de Lei do Senado n.219/06, que foi encaminhado à Câmara dos Deputados como PL 7361/06, aprovado em 12/12/06 e encaminhado para a sanção do Presidente da República, que sancionou o projeto e, em 8 janeiro de 2007, foi publicada a Lei 11.445.

Esta Lei trás em seu bojo os princípios que constituem os serviços públicos essenciais e sua elaboração contou com a participação de órgãos de Estado, associações relacionadas aos serviços de saneamento básico, representantes de usuários e empresas privadas.

A Lei 11.445 apresenta alguns avanços, entre eles a preocupação com a elaboração de um Plano de Saneamento Básico, a previsão da participação social em questões relacionadas à revisão tarifária e, também, a preocupação concernente à 
necessária independência e capacitação técnica por parte das entidades responsáveis pelas funções de regulação.

De acordo com a Lei 11.445/07 as entidades criadas com a finalidade de regulação têm por responsabilidade a fiscalização dos aspectos sociais, econômicos, técnicos e jurídicos das atividades envolvendo a prestação dos serviços.

Estas entidades ainda devem se responsabilizar pela fiscalização do cumprimento das metas estabelecidas no Plano de Saneamento que deve ser apresentado. Este Plano, de acordo com a Lei, deve incluir um diagnóstico da situação atual dos serviços de saneamento básico e uma avaliação dos impactos que a ausência desses serviços impõe às populações urbanas.

Estão previstos, na elaboração deste Plano, a utilização de indicadores sanitários, epidemiológicos, ambientais e socioeconômicos, devendo ser apontadas as causas das deficiências e propostas metas com prazos estipulados para sua resolução.

Além da fiscalização, as entidades reguladoras, de acordo com o artigo 23 da Lei 11.445/07, serão responsáveis pela edição de normas técnicas, abrangendo vários aspectos, que deverão nortear os novos contratos de concessão dos serviços.

Quanto a estas normas, o artigo 28 do Projeto de Lei 7361/06 condicionava a delegação dos serviços públicos de saneamento básico não somente à existência de Planos de Saneamento Básico e a existência de normas de regulação, mas também especificava em seu item "III - a existência de estudo comprovando a viabilidade técnica e econômico-financeira da prestação do serviço, nos termos do respectivo plano de saneamento básico”. Isto poderia contribuir para a construção de um quadro mais preciso quanto às imperfeições e potencialidades dos serviços, evitando surpresas financeiras em relação às necessidades de investimentos, diminuindo consequentemente o risco para os prestadores e para os consumidores. Contudo, este artigo foi vetado na nova Lei.

No que diz respeito ao aspecto da conformação legal no que tange a regulação dos serviços de saneamento básico no Brasil, foi dado um passo importante, resta saber como serão cumpridas muitas das questões tratadas, tais como a independência orçamentária das entidades responsáveis pela regulação, a capacitação técnica e autonomia administrativa necessárias à garantia do respeito às decisões tomadas.

Cabe lembrar a enorme heterogeneidade do território brasileiro no que diz respeito ao desenvolvimento econômico e técnico, sendo que não foram claramente discutidas as vias de fortalecimento das entidades reguladoras, especialmente daquelas 
sob a influência de governos municipais economicamente mais pobres e despojados de corpo técnico capacitado para tal responsabilidade.

No capítulo VIII da Lei 11.445/07 está contemplada a participação de órgãos colegiados no controle social, com representação por parte dos titulares dos serviços, dos órgãos governamentais, dos prestadores de serviços, dos usuários e de entidades técnicas e de organizações de defesa do consumidor. O controle social, por sua vez, diz respeito à preservação da saúde pública, ao adequado atendimento aos usuários de menor renda e à proteção do meio ambiente.

A estreita relação entre a proteção do meio ambiente e a preservação da saúde pública sem dúvida pode ser consubstanciada pela adequação dos serviços de saneamento básico. Isto, por sua vez, exige não somente o avanço quanto ao aspecto legal, mas também a articulação entre as políticas públicas urbanas, ambientais e de saneamento básico.

Durante muito tempo esta articulação foi dificultada pela setorialização do ordenamento institucional dos serviços de infra-estrutura, como observado por Silva (1999, p.273) e que dificultaram ou mesmo impediram a aceitação das políticas advindas de diferentes instâncias.

Neste sentido, tendo em vista que a União adota como base territorial a Bacia Hidrográfica para instituição do Plano de Saneamento e que os Comitês de Bacias Estaduais vêm contribuindo com a discussão de questões pertinentes às políticas públicas urbanas, ambientais e sanitárias, acreditamos que a participação dos mesmos, nos colegiados previstos, pode ser um passo positivo para superação desta setorialização. Como os Comitês de Bacia tem expressado esforços no sentido de ampliar a participação de representantes da municipalidade com boa aceitação por parte destes últimos, isto poderia ser incorporado na conformação destes órgãos colegiados.

Apesar de conter avanços com apresentação de propostas que buscam maior transparência e regras claras para o setor, a Lei 11.445/07, ainda deixa dúvidas sobre o desenvolvimento do setor, sobretudo no que concerne às questões de ordem econômica. Como foi discutida, a autonomia financeira é pré-requisito para a independência das entidades reguladoras responsáveis pela elaboração das normas, pelo controle do cumprimento dos planos e, consequentemente, pela eficiência do setor. No entanto não foi esclarecido como será possível o alcance desta autonomia, tendo em vista a crise econômica em que se encontra o Estado brasileiro. 
Em relação à questão econômica, nota-se que a Lei sancionada deu grande ênfase à garantia de equilíbrio financeiro às concessionárias com possibilidade de pagamento de indenizações que superam os investimentos efetuados em infra-estrutura.

De acordo com as disposições finais da Lei 11.445/07 uma nova redação foi dada à Lei 8.987/95 que trata sobre o regime de concessão e permissão da prestação de serviços públicos. Vários novos parágrafos foram acrescentados à Lei 8.987/95, no que concerne ao encerramento dos prazos de concessões, aos procedimentos para garantir a retomada da infra-estrutura dos bens reversíveis e o equilíbrio financeiro quanto aos investimentos ainda não amortizados, por parte da concessionária que encerra suas atividades. Entre estes parágrafos, destaca-se o parágrafo $5^{\circ}$ do artigo 58 , na qual as indenizações efetuadas no ato de encerramentos de contratos devem estar atreladas também aos investimentos não amortizados em prestação dos serviços, que podem se relacionar às movimentações financeiras da empresa concessionária.

Neste sentido, como discutiremos com maiores detalhes mais a frente, este parágrafo abre uma brecha para a utilização de dívidas em transações financeiras envolvendo empresas do mesmo grupo como investimentos não amortizados.

Deve-se destacar que também a questão polêmica sobre a titularidade dos serviços de saneamento básico não foi solucionada, devendo ser remetida, caso a caso, à decisão do Supremo Tribunal Federal.

Como a maior parte dos municípios situados em regiões metropolitanas concedeu, na década de 1970, os seus serviços às empresas estaduais, tais como a Sabesp, no Estado de São Paulo, são estas companhias que continuam responsáveis pelos serviços nestas áreas. Contudo, como ressalta Vargas e Lima (2004), com o término do prazo das concessões às companhias estaduais, aos poucos os municípios vêm retomando o poder decisório sobre a prestação dos serviços e isto pode implicar em desdobramentos não vantajosos para os usuários.

A assunção dos serviços de forma descentralizada, em regiões metropolitanas, por parte das instâncias municipais pode implicar na inviabilidade de aplicação de políticas de subsídio cruzado, das quais se utilizam as companhias estaduais. Também, a concessão dos serviços, por parte destas instâncias municipais à iniciativa privada é uma possibilidade e isto, pode comprometer o funcionamento das redes de infra-estrutura que estão concebidas com base no espaço metropolitano, sendo que, alguns municípios possuem papel estratégico do ponto de vista de reservação de água, de bombeamento e do tratamento de esgotos que atendem todo o sistema. 
É possível notar que a nova Lei sancionada abre novas possibilidades de fortalecimento da estrutura de controle por parte do poder concedente dos serviços, mas também possibilita uma maior segurança para as concessionárias que podem avaliar mais claramente seus custos e as potencialidades de obtenção de lucro. Deste modo, não é possível prever, com precisão, se o cumprimento da Lei será motivo de maior atração ao capital transnacional ou se as maiores cobranças previstas causarão repulsa ao avanço dos grupos privados transnacionais, mas certamente as regras claras para atuação do setor são bem-vindas para aqueles que almejam promover melhorias e crescer com elas.

Foi possível destacar algumas características em comum entre os casos estrangeiros citados e os casos brasileiros estudados quanto à atuação da iniciativa privada.

Com o intuito de reduzir o ônus do Estado, a privatização foi adotada, mesmo por países cujo desenvolvimento econômico e renda per capta possibilitavam os investimentos no setor. Contudo, como ocorreu na França e na Inglaterra, os investimentos não foram efetuados a partir de antecipação de recursos financeiros próprios advindos da iniciativa privada, mas foram socializados pelos usuários por meio do aumento constante de tarifas.

Da mesma forma, na ânsia de desonerar o poder público, municípios brasileiros, como Limeira, que poderiam ter solucionado a questão dos investimentos por outras vias, optaram pela privatização do setor de saneamento básico e tiveram que arcar com os custos dos investimentos, os quais foram rateados entre a sociedade por meio da aplicação de altas tarifas.

Como pudemos discutir, em países como a Inglaterra e a França os usuários sofreram com os aumentos tarifários e o controle sobre a efetivação dos investimentos se deveu a funcionalidade das entidades de regulação, que por sua vez, também passaram por um período de adaptação e ajustes em suas práticas.

Em todos os exemplos citados é marcante o uso de subterfúgios para o não investimento tais como argumentação sobre o desconhecimento da precariedade da infra-estrutura concedida e sobre a impossibilidade de extensão dos subsídios cruzados devido à insuficiência financeira. Estes argumentos em geral são acompanhados de solicitação de revisão das tarifas às entidades reguladoras.

Outra questão que também permeia os exemplos abordados é o da limitação das entidades reguladoras no controle e fiscalização da atuação da iniciativa privada. Deste 
modo, o risco de captura do regulado pelo regulador é alto, já que as fragilidades do Estado são reproduzidas nos acordos firmados. Observa-se, portanto, por parte das entidades reguladoras, a dificuldade de obtenção de autonomia financeira, bem como a dependência das informações produzidas pelas concessionárias, que associada à limitação na capacitação do corpo funcional das entidades reguladoras, podem dificultar a análise efetiva da atuação das concessionárias e a cobrança de resultados.

Se a questão da regulação dos serviços de saneamento básico é um ponto importante para a compreensão do desenvolvimento dos investimentos no setor, também a análise das movimentações do mercado financeiro em relação o setor de saneamento básico é importante para que possamos compreender a lógica da reprodução ampliada do capital.

Deste modo, procuramos contemplar, no item a seguir, o desenvolvimento das discussões que envolvem a relação entre o mercado financeiro e o setor de saneamento básico. 


\section{O mercado financeiro e o setor de saneamento básico}

O crescimento do interesse de atuação de grandes grupos privados na prestação de serviços relacionados à água, como é o caso dos serviços de saneamento básico, é um fator relativamente novo. Isto se deve à associação de alguns fatores, entre eles a possibilidade de atuação em um setor com características de monopólio, a possibilidade de integração vertical entre as empresas subsidiárias e, finalmente, a possibilidade de atração de investimentos e ampliação do capital por meio do lançamento de ações no mercado financeiro.

Todos estes fatores foram possibilitados por ações promovidas pelos governos Thachter e Regan na década de 1980, que impulsionaram, segundo Chesnais, “as políticas de liberalização, de privatização, de desregulamentação e de desmantelamento de conquistas sociais e democráticas”39.

A liberalização do mercado financeiro, a partir de meados da década de 80, possibilitando a emissão de títulos negociáveis a curto prazo, ampliou, segundo Serfati (1998), a possibilidade de intervenção de empresas no mercado monetário e a ascensão de grandes grupos econômicos, que atuavam por meio de holdings, ao mercado financeiro mundial, ampliando as vias rentistas de acumulação do capital.

Deste modo, como demonstra Chesnais (1996) o Investimento Externo Direto IED apresentou grande crescimento a partir da década de 1980, especialmente no que concerne ao setor de serviços e, dentro deste, os investimentos no setor financeiro.

Cabe observar que de acordo com a Organização para a Cooperação Econômica e Desenvolvimento - OCDE -, os investimentos externos diretos são formados por investimentos “diretos” e por investimentos “de carteira”. Ainda, segundo Chesnais (1996, p.56), a OCDE definiu como investimentos diretos aqueles superiores a 10\%, que dariam direito a voto e, por conseguinte, o direito de opinar em decisões sobre determinada empresa. Os investimentos em carteiras foram definidos como aqueles inferiores a $10 \%$, que não dariam poder de voto ao investidor.

As sociedades anônimas em geral estão abertas às estas duas formas de investimento. Elas podem atrair investimentos de carteira, via operadores nas bolsas de valores, ou investimentos diretos que podem resultar em fusões ou aquisições por parte

\footnotetext{
${ }^{39}$ CHESNAIS, François. A Mundialização do Capital. São Paulo: Xamã, 1996, p.34.
} 
de uma empresa por outra, ou por parte de um grupo de empresas, comandado em geral por uma holding.

Com base em informações da Conferência das Nações Unidas para o Comércio e Desenvolvimento - UNCTAD é possível afirmar que apesar dos investimentos no setor de saneamento básico ser baixo comparado às outras infra-estruturas privatizadas, como o setor de telecomunicações ou de energia, estes investimentos representaram cerca de U\$35 bilhões entre 1987 e 2002 e dizem respeito a um pequeno número de grandes grupos transnacionais, dentre eles o grupo francês Suez S.A.

As concessões dos serviços de saneamento por parte de empresas ligadas aos grupos transnacionais, a exemplo do Suez S.A., em diversos países, fazem parte de um processo de centralização econômica, tal qual destacou Lencioni (1994, p.58).

Segundo Lencioni a “centralização é, portanto, uma reorganização da distribuição da propriedade de capitais, do seu controle" ${ }^{40}$. Esta reorganização é obtida por meio da compra de parte significativa das ações de empresas menores, de modo que a autonomia destas últimas desaparece. O que fica é o comprometimento com os interesses da empresa holding do grupo que, em geral, é representada por uma entidade financeira. Deste modo se explica o pequeno número de grandes grupos privados relacionados aos serviços de saneamento básico, entre eles o Suez S.A.

Além da possibilidade de incorporação de capitais já formados pelos grupos transnacionais, há também a possibilidade de captação de investimentos de carteira. Estes investimentos, quanto ao seu montante individual não representam grandes somas e são incapazes de interferir nas decisões do grupo; contudo, considerados em relação ao grande movimento de investimentos como um todo, a exemplo dos movimentos de ações envolvendo fundos de pensão, podem contribuir, ainda mais, para o fortalecimento destes grupos e para o incremento de sua centralização.

O acompanhamento deste movimento de centralização, por sua vez, é complexo, tendo em vista que as fusões e incorporações ocorrem com grande dinamismo, alterando denominações e atuando em diferentes setores, o que mascara suas conexões.

Lembramos que no final da década de 90 a empresa Générale dês Eaux passou a adotar o nome de Vivendi Environnement e, em 2003, Veólia Environnement. Do mesmo modo, a empresa Lyonnaise des Eaux foi incorporada ao grupo Suez S.A. em

\footnotetext{
${ }^{40}$ LENCIONI, Sandra. Reestruturação urbano-industrial no Estado de São Paulo: a região da metrópole desconcentrada. In: Revista Espaço \& Debates n.38, 1994,p.58. p.54-61.
} 
1997, passando a denominar-se Suez Lyonnaise des Eaux para depois assumir a denominação de Suez Environment em 2005.

Pode-se afirmar que a alteração de designação por parte destas grandes corporações, além de estar relacionada ao processo de fusões e incorporações de empresas, também auxilia a resguardar o grupo de problemas relacionados ao desgaste com sua imagem.

Segundo Bau (1998) ocorreram vários escândalos envolvendo grandes grupos econômicos. Entre estes escândalos constam alguns ocorridos na França, em meados da década de 90, envolvendo altos funcionários da Générale des Eaux e da Lyonaisse des Eaux (hoje Suez) relacionados à investigação de financiamento de partidos políticos do governo, contratação de obras sem concurso, fraudes nos processos de concorrência e obtenção de lucros, que encareciam sobremaneira a gestão privada do serviço. Portanto, a alteração de nome pode ter sido parte de uma estratégia importante naquele momento para minimizar os efeitos dos escândalos.

É importante notar que o grupo Suez S.A. cresceu apoiando-se em sua experiência nos serviços relacionados à água. Deste modo, ainda que o grupo atualmente tenha expandido amplamente seus serviços a outros ramos de atuação, como telecomunicações, energia (não somente a hidroelétrica), transporte, entre outros, podese afirmar que a marca Suez S.A. ainda se ampara fortemente na idéia de domínio do conhecimento técnico e administrativo de serviços relacionados à água.

Segundo relatório de performance do próprio grupo Suez S.A. ${ }^{41}$ as atividades relacionadas à água foram as que obtiveram maior crescimento (49\%) entre o período de 1999/2000, resultante de novas incorporações contra 23\% de crescimento do setor de energia dentro do grupo.

Entre 2004 e 2005 os investimentos em atividades ligadas ao setor energético superaram os investimentos em atividades relacionadas à água. Isto, no entanto, não significa a perda de importância das atividades ligadas à água, mas à crescente valorização das empresas relacionadas ao setor de energia, o que não exclui a relação com a água, já que em grande parte estas ações se referem também à dependência da água por meio das empresas de geração de hidroeletricidade.

O que deve ser destacado é que, desde o período analisado, em meados da década de 1990, quando a empresa Lyonnaise des Eaux, hoje fundida com o grupo Suez

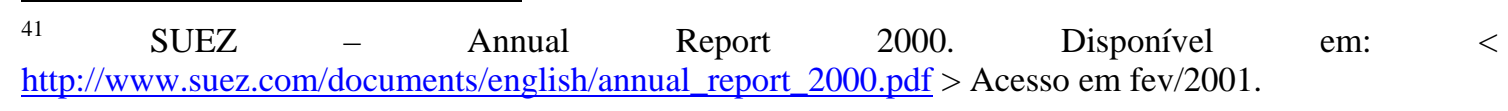


S.A. adquiriu a concessão dos serviços no município de Limeira, até meados de 2005 as ações do grupo têm apresentado movimento crescente nas bolsas de valores de Nova York.

Como resultado, os dividendos pagos aos acionistas têm sido também crescentes, especialmente nos últimos três anos, como pode ser observado no gráfico a seguir.

\section{Gráfico 8}

Suez S.A. Evolução dos dividendos, por ações do grupo entre 1997-2005.

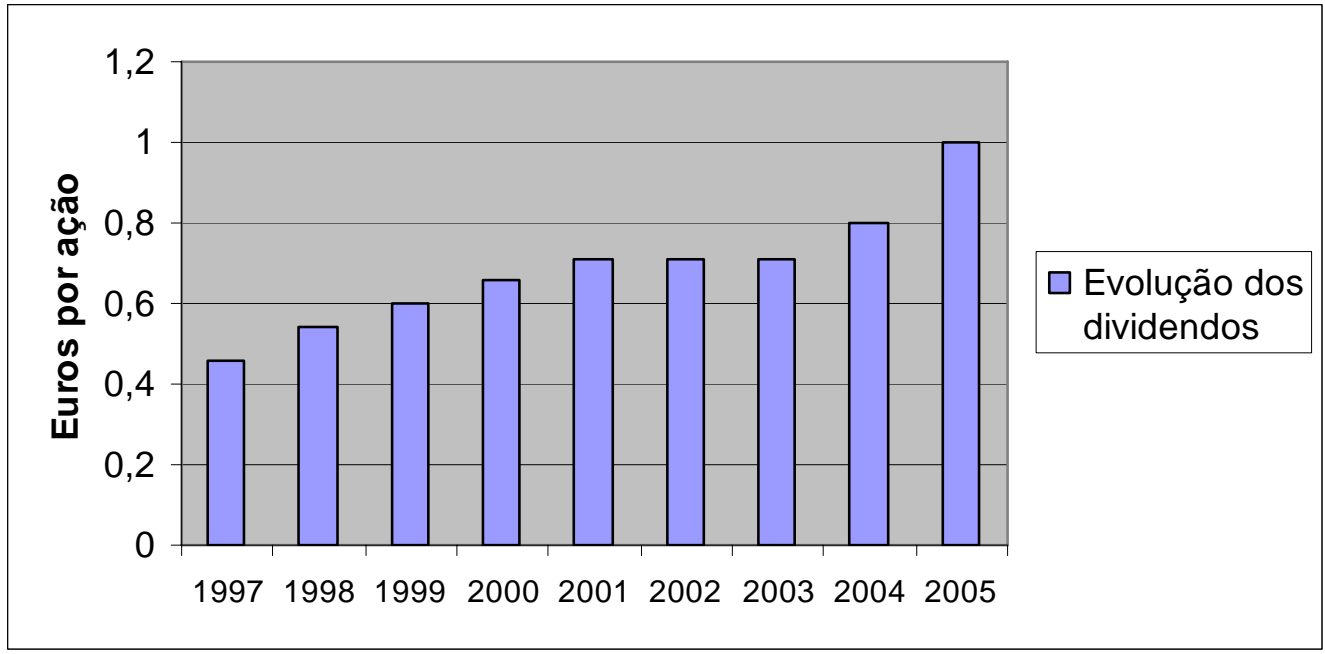

Fonte: SUEZ. Espace Actionnaires. Disponível em: <

http://www.suez-lyonnaise-eaux.fr/finance/french/actionnaires/espace/index-dividende.php> Acesso em 07/08/2005 e 10/09/06.

Ainda, segundo a mesma fonte de informações, as atividades relacionadas à "Suez Environment”, na qual se incluem as atividades de saneamento básico, foram responsáveis pela geração de 11,1 bilhões de euros em investimentos em 2005, contra 10,5 bilhões de euros para o ano de 2004.

Ao analisarmos com maior detalhe os investimentos do grupo é possível observar que entre meados dos anos 1990 e início dos anos 2000, grande importância era dada às novas aquisições. Estas aquisições eram embasadas no crescente número de pessoas que não possuiam acesso à água, conforme documento informativo do grupo transcrito a seguir:

ONDEO serves two key market segments: the municipal segment and the industrial segment, representing $64 \%$ and $36 \%$ of its revenues respectively. The development of the first is conditioned by a fundamental geopolitical reality: 800 million human beings have 
limited access to quality drinking water and, in 2025, their numbers could swell to four billion (source: Suez Lyonnaise des Eaux). ${ }^{42}$

O objetivo de conquistar o denominado "mercado municipal”, ou seja, os usuários domésticos foi prioridade do grupo, já que isto significava, a princípio, a incorporação de milhões de novos usuários e, portanto, de novos consumidores pagadores. Segundo o mesmo relatório do grupo Suez, o número de novos usuários dos serviços de saneamento básico, incorporados pelos novos contratos, foram 14 milhões em 2000.

Tão importante quanto à captação de grande número de novos usuários é a captação de pontos importantes quanto à ocorrência de água e, neste sentido, é interessante observar que, entre os principais contratos efetuados no ano 2000, o relatório anual publicado pelo grupo Suez, destaca o caso de Manaus, tendo sido o primeiro a ser citado.

Certamente, este destaque não ocorreu devido ao número de usuários potenciais, já que os demais também citados possuíam populações muito maiores, mas devido à sua localização estratégica no que concerne à água. Deste modo, procuramos transcrever a seguir as palavras constantes no documento apresentado pelo grupo em 2000 sobre as novas aquisições:

Among the most important contracts were the concession contracts at Manaus in Brazil, Águas Cordillera in Chile, Baoding and Zhegzhou in China, the BOT of Yangju in Korea, Ayshire and Levenmouth (Scotland), the water supply contract for Casablanca, Morocco, the water concession for Johannesburg in South Africa, and the acquisition of Société nationale des Eaux du Cameroun ${ }^{43}$

42 SUEZ. Anual Repport 2000.p.29. Disponível em: < http:// www.suez.com/documents/english/annual_report_2000.pdf $>$ Acesso em fev/2001.

"Ondeo serve a dois segmentos chave: o segmento municipal e o industrial, representando 65\% e $36 \%$ de seus investimentos respectivamente. O desenvolvimento do primeiro é condicionado por uma realidade geopolítica fundamental: 800 milhões de seres humanos tem acesso limitado a água potável de qualidade e, em 2025, seus números poderão ultrapassar 4 bilhões (fonte: Suez Lyonnaise des Eaux)” Trad. Cristiane F. de Oliveira.

${ }^{43}$ Ibidem. p.29.

"Entre os contratos mais importantes estavam os contratos de concessão em Manaus no Brasil, Águas Cordilheiras no Chile, Baoding e Zhegzhou na China, o BOT of Yangju na Korea, Ayshire e Levenmouth (Escócia), o contrato de abastecimento de água para Casa Branca no Marrocos, a concessão de água para Johanesburgo na África do Sul e a aquisição da Sociedade Nacional de Água dos Camarões”. Trad. Cristiane F. de Oliveira. 
Neste sentido, o foco da expansão dos investimentos do grupo naquele período estava apontado para as novas incorporações por meio dos novos contratos firmados com os governos dos países citados e com outros países em anos seguintes.

Em 2005, também as aquisições e incorporações foram responsáveis pela maior contribuição ao montante total de capital do grupo. A maior contribuição adveio das atividades ligadas ao setor energético, o que não significou, no entanto, em descontinuidade na forma de atuação das empresas ligadas às atividades denominadas “ambientais”, ou seja, ligadas à Suez Environment, responsável pelos negócios relacionados à água e aos resíduos sólidos.

No que tange aos serviços de água, em 2005, grandes negócios foram feitos com a China, envolvendo fusões e aquisições. Ainda, em 2005, grande parte dos lucros advindos de países externos aos de origem (França) se deu especialmente em relação à obtenção de receitas oriundas dos aumentos de tarifas cobradas pelos serviços de operação dos sistemas, ao exemplo do caso da “Águas Andinas” no Chile, que proporcionou ao grupo Suez S.A. lucros da ordem de 29 milhões de euros.

Foi possível notar que a lucratividade advinda das atividades de operação do setor de saneamento básico, não depende somente da expansão dos serviços e, portanto, do aumento do consumo e, consequentemente, da arrecadação, mas também da possibilidade de haver correção tarifária com o aumento dos preços dos serviços.

O poder aquisitivo dos usuários ainda continua sendo um fator limitante à obtenção de lucratividade no que concerne a cobrança pelos serviços prestados. Deste modo, a lucratividade obtida por meio do aumento tarifário é pontual, ocorrendo em momentos de correções tarifárias, em geral previstas contratualmente, mas mesmo assim, atinge fortemente o orçamento familiar de grande parte dos usuários.

Foram as empresas européias ligadas ao grupo Suez S.A., principalmente as francesas e as espanholas, que garantiram em 2005 a lucratividade nas atividades de operação no setor de saneamento básico. A exceção na obtenção de lucro, por parte de países dependentes, se deu com a empresa “Águas Andinas” no Chile, devido ao aumento das tarifas.

Grande parte da rentabilidade do grupo se apóia nas fusões e incorporações, já que o capital já formado é incorporado imediatamente. Este capital pode ser incorporado de forma onerosa, ou seja, com pagamento pela obtenção de ações da nova empresa ou de forma não onerosa, ou seja, por meio da captação de concessões sem a necessidade de desembolso de recursos. Neste sentido, quanto menos recursos 
financeiros forem necessários nas transações de incorporação do novo capital ao grupo, mais vantajoso é o negócio.

Consequentemente, as concessões não onerosas, ou seja, aquelas que não obrigam pagamento pelo direito de exploração dos serviços, são vantajosas, já que não requerem investimento imediato.

Deve-se fazer uma pausa neste momento, para lembrar que o PL 4147 de 2001, retirado do Congresso pelo Ministro das Cidades Olívio Dutra, proibia a concessão onerosa dos serviços, como destacado por Vargas e Lima (2004, p.74). Como este projeto não foi consumado, a forma onerosa de concessão ainda existe.

Se por um lado as concessões não onerosas são atraentes aos grupos por não exigir desembolso imediato de dinheiro, por outro as concessões onerosas vistas sob o aspecto da possibilidade de persuasão econômica dos titulares dos serviços e ampliação das possibilidades de concessões à iniciativa privada, podem ser também atraentes.

De fato, a municipalização dos serviços, aliada à possibilidade de obtenção de recursos advindos das concessões onerosas pode estimular a transferência dos serviços de saneamento básico à iniciativa privada, mas obviamente não são todas as localidades que interessam ao grupo. Os negócios interessantes devem possuir atributos que interessam ao grupo, devendo-se considerar os investimentos necessários, a importância do seu posicionamento frente a ocorrência de recursos hídricos ou as receitas potenciais e as vias de financiamentos viáveis.

Nos casos de pequenas e médias cidades, as concessões são obtidas, em geral, de forma não onerosa, o que é interessante para a iniciativa privada e em troca atrela-se as menores tarifas oferecidas aos usuários como parte de benefícios aos consumidores locais. Em geral, nesta forma de concessão, os reajustes estão fixados nos contratos e são definidos em negociações entre o poder concedente e a concessionária.

Além da possibilidade de obtenção de rendimentos por meio das aquisições e fusões, com implementação do montante de capital, também os grandes grupos têm atraído os investimentos individuais por meio das aplicações dos fundos mútuos em mercados de capitais internacionais das bolsas de valores. Estes fundos mútuos são, segundo Sanchez (1999, p.77) a forma mais simplificada de aquisição de ações por parte do investidor individual e se constituem em uma somatória de pequenos investimentos que são reunidos e administrados por uma companhia.

A captação destes fundos por parte dos grandes grupos econômicos, entre eles o Suez S.A., aliado às incorporações e aquisições e à obtenção de lucros advindos das 
operações dos serviços por parte das subsidiárias, constituem estratégias de ampliação do capital e, são inclusive, amplamente divulgadas como forma de mostrar aos possíveis investidores que o crescimento do grupo está amparado em diversas fontes.

Porém, enquanto são divulgadas as aquisições e incoporações, a obtenção de lucro por meio do aumento de tarifas e captação dos fundos mútuos como vantagens, os investimentos necessários em recuperação de estruturas físicas bem como a deterioração econômica e contratual são divulgados como perdas do grupo. Quanto a isto o grupo Suez S.A. citou, como exemplo de perdas em seu relatório anual, o caso do Brasil e da Argentina, sem especificação de detalhes.

É possível admitir que equipamentos precários ou necessidade de substituição de infra-estrutura deteriorada realmente comprometam as metas de lucro almejadas, mas isto pode ser revertido. A recuperação e substituição desta infra-estrutura poderiam contribuir para o aumento da cobertura dos serviços e, por conseguinte, para o aumento do consumo, cobrindo, deste modo possíveis perdas.

No entanto, ao contabilizar a deterioração econômica e contratual de países como o Brasil, há uma racionalização por parte das empresas sobre os riscos de investimentos em melhoria das condições da infra-estrutura, resultando em diminuição destes investimentos.

Deste modo, dentro da racionalidade empresarial, a obtenção de rentabilidade e lucratividade pode se dar sem grandes investimentos em ampliação da capacidade operacional dos serviços, o que tem refletido em manutenção ou mesmo em ampliação dos déficits de serviços no âmbito local.

\subsection{Crescimento e estagnação: as duas faces da atuação do grupo Suez S.A. no setor de saneamento básico no Brasil}

Como pudemos discutir sucintamente no capítulo I os investimentos privados em serviços de saneamento básico em Manaus entre 2000 e 2004 mostraram-se inferiores aos do período que antecedeu a privatização.

Deste modo, enquanto em Manaus, entre 1995 e 1999 foi investido pelas instâncias públicas R\$87.645.348,00 em expansão da capacidade de abastecimento de água, entre 2000 e 2004 foi investido R\$58.832.579,00 pela iniciativa privada. Do mesmo modo, entre 1995 e 1999 houve investimentos por parte da instância pública de R\$11.514.574,00 em ampliação da capacidade das redes de esgoto contra investimentos de $\mathrm{R} \$ 2.053 .718,00$ entre 2000 e 2004, por parte da iniciativa privada. 
Com relação aos investimentos efetuados em Limeira não há fonte de dados para o período anterior à concessão e, portanto, não é possível efetuar a comparação entre os investimentos efetuados pela municipalidade e os investimentos privados. Contudo, segundo Justo (2004), que analisou o caso de Limeira nos primeiros anos de concessão, entre 1996 e 2000, os investimentos totais efetuados não alcançavam os valores contratados, sendo a partir de 2001 que os investimentos passaram a suplantar estes valores.

Somente em 2004 (última informação divulgada pelo SNIS) os valores totais acumulados de investimentos desde 1996, que somam $\mathrm{R} \$ 39.327 .478,00$, superaram os valores contratados para o mesmo período que equivaliam a $\mathrm{R} \$ 38.887 .000,00$.

A insuficiência de investimentos, segundo a empresa “Águas de Limeira” ligada ao grupo Suez S.A., teria sido resultado do “congelamento" das tarifas imposto pelo governo municipal entre 1996 e 2000.

Contudo, como veremos, os fracos investimentos em ampliação e melhoria dos sistemas de saneamento básico em Limeira, no período corroboram a estratégia do grupo para a ampliação do capital, fundamentada em direcionar custos em outras formas de obtenção de renda, com obtenção de novas aquisições no exterior.

Deste modo, analisando a movimentação financeira do grupo Suez no período entre 1996 e 2000, foi possível notar que as aquisições e incorporações continuaram a ocorrer, sendo que podemos citar, em 1998, aquisições relacionadas aos serviços de saneamento básico no Cairo - Egito, em Atlanta - EUA, em Arezzo - Itália e em Amman na Jordânia. Em 1998 houve um crescimento do grupo de 8\% e, em 1999, o grupo Suez S.A. passou a controlar, com 99,5\% das ações, a empresa Tractebel que possuía naquele período importantes negócios no setor energético na América Latina, inclusive com o controle de 68\% da empresa Gerasul, o segundo maior pólo de geração de energia no Brasil, segundo informações divulgadas pelo grupo Suez ${ }^{44}$.

Em Limeira os investimentos foram refreados, chegando ao seu menor valor em 1999, como podemos observar na tabela a seguir, que busca demonstrar a comparação entre os investimentos efetuados pela empresa e os investimentos contratados.

\footnotetext{
${ }^{44}$ SUEZ. Relatórios Anuais 1998 e 1999. Disponível respectivamente em: < http://www.pargesa.ch/sujet_en/pdf/ra/ra98/an_suez_pdf $>$ e $<$ http://www.pargesa.ch/sujet_en/pdf/ra/ra99/an_suez.pdf > Acesso em 05/07/06
} 
Tabela 3

Limeira: Investimentos totais efetuados e contratados em abastecimento de água, coleta e tratamento de esgotos entre 1996 e 2004

\begin{tabular}{||c|c|c||}
\hline \hline Período & $\begin{array}{c}\text { Investimentos Efetivados* } \\
\text { Valores em milhares de Reais }\end{array}$ & $\begin{array}{c}\text { Investimentos Contratados ** } \\
\text { Valores em milhares de Reais }\end{array}$ \\
\hline 1996 & 3.090 & 5.186 \\
\hline 1997 & 2.919 & 5.430 \\
\hline 1998 & 2.718 & 10.651 \\
\hline 1999 & 1.135 & 5.713 \\
\hline 2000 & 1.354 & 2.387 \\
\hline 2001 & 4.108 & 3.801 \\
\hline 2002 & 6.834 & 2.582 \\
\hline 2003 & 7.934 & 1.347 \\
\hline 2004 & 9.236 & 1.790 \\
\hline
\end{tabular}

Fonte: * SNIS e **Anexo II do contrato de concessão organizado por Justo (2004, p.139), atualizado. até 2004 .

É interessante notar que em 1996 a inflação acumulada, de acordo com o IPEA foi de 9,94\%, no entanto o pedido de reajuste das tarifas, solicitado pela empresa Águas de Limeira, era de 48\%. Ainda, logo no primeiro ano de concessão foi visível o descumprimento das metas previstas no contrato firmado, com investimentos inferiores aos valores contratados.

A crítica de Justo (2004, p.141) é dirigida ao atraso nos investimentos, como resultado da opção da empresa de remessa de lucros à matriz. Segundo o autor para que os investimentos contratados fossem efetuados e para que se viabilizasse o envio de lucros à matriz pela empresa as tarifas deveriam ser mais altas do que as contratadas.

Deste modo, procurando auxiliar a compreensão do aspecto tarifário Justo (2004, p.120) faz uma retomada histórica dos fatos ocorridos e, relata que um ano antes da concessão o prefeito Jurandir Paixão de Campos Freire aumentou em 51\% os preços das tarifas, na esteira da conversão da moeda brasileira (quando foi introduzido o Real).

Quando a empresa obteve a concessão em 1995, os aumentos nas tarifas que haviam sido implementados um ano antes foram absorvidos por ela, ou seja, passou a ser aplicado pela empresa naturalmente, o que garantiu segundo Justo (2004, p.122) a 
operação dos serviços pela empresa em um patamar muito mais alto do que a empresa pública anteriormente operava.

É importante notar também, que o contrato não oneroso para o caso de Limeira, também levava em consideração o fato de que a empresa deveria operar com a menor tarifa, mesmo prevendo-se reajustes anuais.

Conforme os dados do SNIS para o período de 1996 a 2004, disposto no gráfico a seguir, nota-se que as tarifas mantiveram-se próximas do valor mínimo contratado de $\mathrm{R} \$ 0,55 / \mathrm{m}^{3}$ até o ano 2000, quando houve autorização de reajuste por parte da prefeitura em troca da revisão contratual e assunção de parte das dívidas pela empresa.

\section{Gráfico 9}

\section{Limeira. Evolução das tarifas médias aplicadas sobre o abastecimento de} água e coleta de esgoto entre 1996 e 2004.

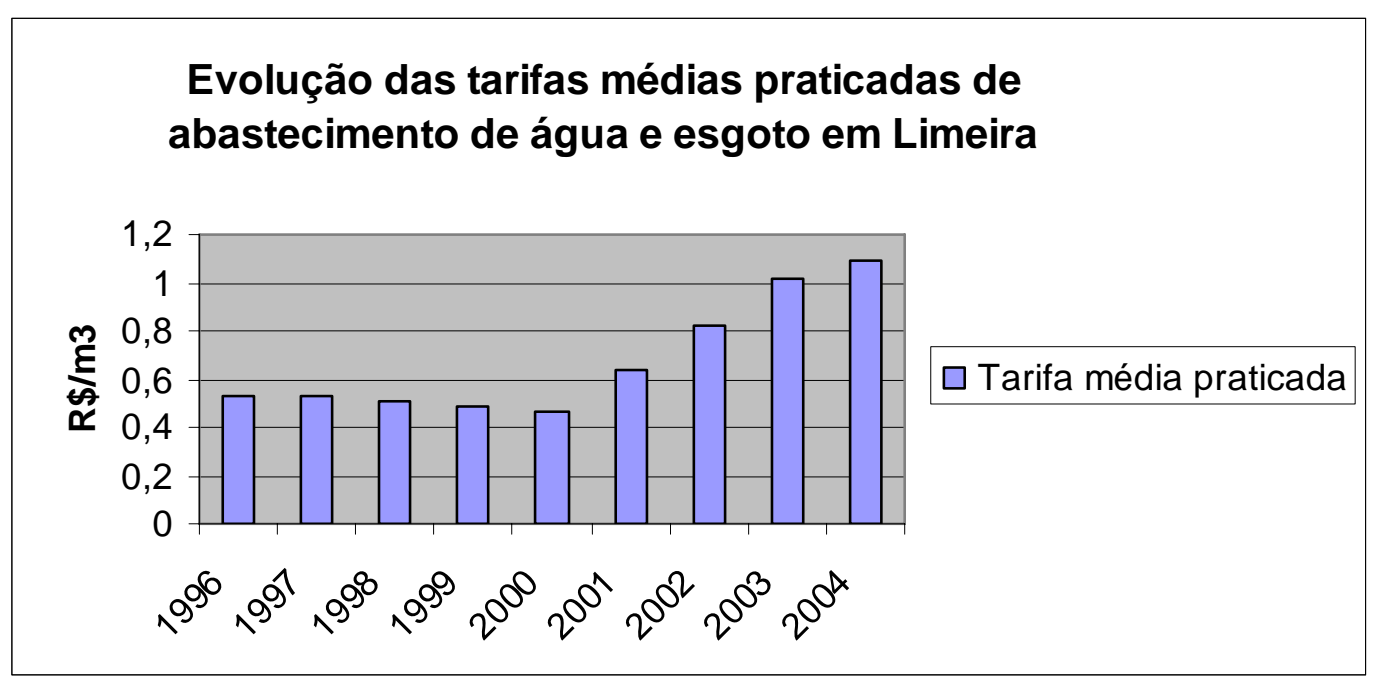

Fonte: SNIS. Relatórios anuais.

Organização: Cristiane F. Oliveira

Deve-se destacar que houve conflitos durante o período entre 1996 e 2000 envolvendo a prefeitura de Limeira e a empresa sobre os reajustes previstos no contrato. Quando o novo prefeito de Limeira assumiu em 1996, o pedido de reajuste de $48 \%$ por parte da empresa foi negado, conforme lembra Justo (2004, p.123), o que perdurou até 2000, quando foram autorizados aumentos na ordem de 63,49\%.

Não é possível negar que correções nas tarifas eram necessárias, em razão da evolução inflacionária acumulada para o período, como forma de proporcionar o equilíbrio financeiro para operação dos serviços e garantir os volumes de investimentos necessários. Contudo, nota-se que os aumentos tarifários solicitados não visavam somente garantir o equilíbrio dos serviços, já que suplantavam a inflação acumulada. 
Ainda, por parte do poder concedente (a prefeitura de Limeira) o congelamento dos preços não dizia respeito somente à discordância quanto aos valores das tarifas, mas também era uma forma de pressão para que a empresa assumisse encargos da dívida de obras de saneamento do período imediatamente anterior à concessão. Dívidas estas, diga-se de passagem, em grande parte com empresas ligadas ao grupo Suez, a exemplo da CBPO e da Degremont, como destacado por Justo (2004, p.125).

Ao assumir as dívidas com empresas do próprio grupo, a empresa Águas de Limeira, na realidade está assumindo a integração vertical dos fluxos de capitais entre empresas do grupo. É importante observar que as relações financeiras envolvendo sempre empresas do grupo são muito comuns e, em geral, as dívidas resultantes destas transações são altas, possivelmente embutindo lucros que são emitidos a holding do grupo.

Deste modo, os crescentes preços das tarifas a partir de 2000 proporcionaram não somente a recuperação dos déficits em investimentos contratados, mas a continuidade da emissão de lucros à matriz com pagamento das dívidas.

Neste sentido, mesmo com a recuperação dos investimentos a partir de 2001 e com o conseqüente alcance do cumprimento das metas em 2004, para o caso de Limeira foi possível notar que a prioridade não é o atendimento das demandas por serviços de saneamento básico, mas sim o atendimento dos interesses financeiros do grupo.

Em relação às tarifas aplicadas em Manaus pode-se afirmar que houve grande crescimento das mesmas após a concessão e, em 2004, as tarifas estavam entre as mais altas do Brasil.

O gráfico a seguir mostra a comparação das tarifas médias praticadas em Manaus pela Cosama até 2000 e, posteriormente, a partir de 2001, pela empresa Águas do Amazonas. O mesmo gráfico também mostra a evolução das tarifas aplicadas pelas companhias regionais Sabesp-SP e Cosampa- PA, já que a primeira é significativa quanto ao número de municípios que atende e quanto a tarifa que aplica e a segunda possui expressivo preço nas tarifas do ponto de vista regional, facilitando uma possível comparação com as tarifas aplicadas em Manaus. 


\section{Gráfico 10}

Evolução das tarifas aplicadas pela Cosama, Águas do Amazonas, Sabesp e Cosampa entre 1996 e 2004

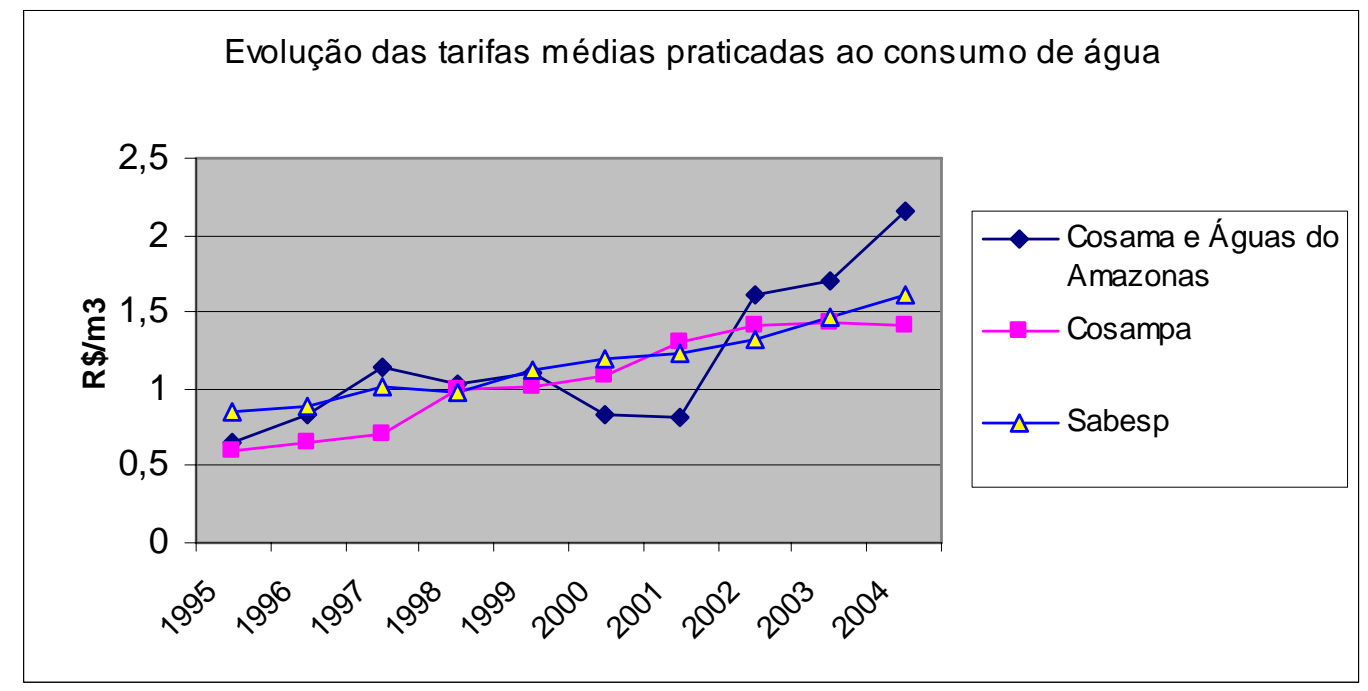

Fonte: Diagnósticos anuais do SNIS/ Organização Cristiane F. de Oliveira

A partir de 2001 a empresa Águas do Amazonas assumiu a responsabilidade pelos serviços e consequentemente pela aplicação de tarifas de água em Manaus. Notase que entre 1999 e 2001, durante o período imediatamente anterior a concessão e durante a transição da atuação da empresa, as tarifas se mantiveram abaixo dos valores com que a empresa vinha operando. Contudo, em 2002 as tarifas sofreram reajustes que ultrapassaram as médias praticadas pela Sabesp e pela Cosampa, esta última atuante na mesma região brasileira que a Águas do Amazonas.

Se compararmos também as tarifas da empresa Águas do Amazonas entre 2002 e 2004 com todas as médias de empresas regionais brasileiras também podemos observar que a empresa ainda aplicava uma das maiores tarifas do país.

Deve ser observado, no gráfico a seguir, que a tarifa de $\mathrm{R} \$ 2,15 \mathrm{p} / \mathrm{m}^{3}$ aplicado pela Águas do Amazonas em 2004 era superada somente por duas empresas regionais brasileiras, a CAERD/RO e a CORSAN/RS. Contudo, por ser um caso isolado, mesmo tendo em vista a alta tarifa praticada pela CAERD em Rondônia, a média aplicada pelas empresas regionais para a região Norte era de $\mathrm{R} \$ 1,50$ por $\mathrm{m}^{3}$ consumido, abaixo da tarifa aplicada em Manaus. 
Gráfico 11

Evolução das tarifas médias praticadas por empresas regionais entre 2002 e 2004

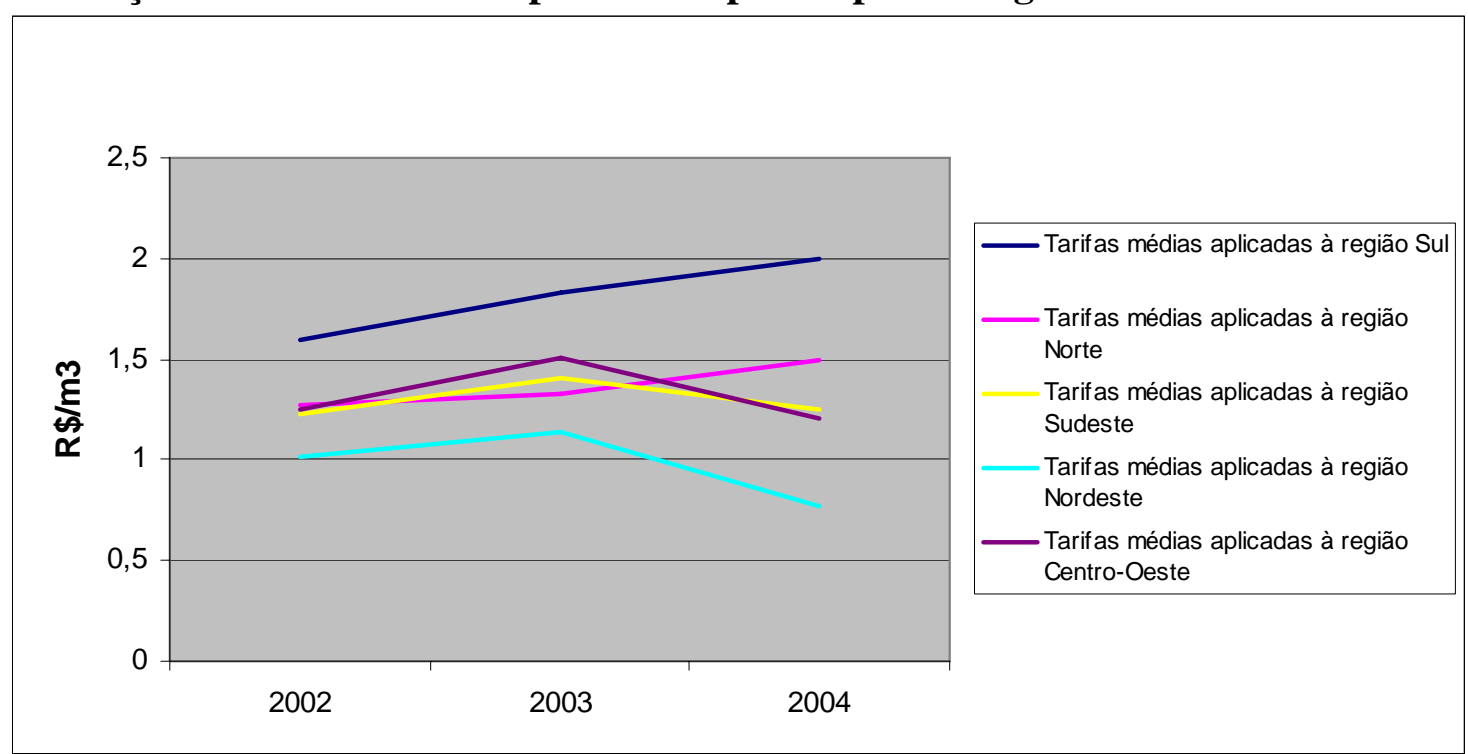

Fonte: Diagnósticos anuais do SNIS/ Organização: Cristiane F. de Oliveira.

Obs: As tarifas se referem às médias regionais brasileiras.

É importante notar que nesta região do país as altas tarifas não correspondem à capacidade de pagamento da população, incorrendo em aumento de inadimplência e de ocorrência de irregularidades na busca do acesso à água, como perfuração de poços sem outorga ou qualquer controle e monitoramento e também no aumento da clandestinidade das ligações de água, como discutiremos no terceiro capítulo.

Outra questão a ser analisada é a das receitas advindas das tarifas e sua relação com as despesas, pois conforme já mencionado por Justo (2004) os fluxos de caixa negativos podem ser encobertos por acúmulo de dívidas nas atividades de operação dos serviços.

Para que fosse possível avaliar as empresas Águas do Amazonas e a Águas de Limeira neste aspecto, tomou-se como referência a evolução da análise das despesas totais, despesas de operação e receitas. Também para o caso de Limeira, procuramos comparar estes parâmetros com outras empresas em municípios da mesma região.

Deste modo, a Tabela 4, a seguir, mostra como se apresenta a relação entre Receitas e Despesas Totais e Despesas com Exploração dos Serviços e também Despesas com Serviços de Dívidas em alguns municípios da Região Administrativa de Campinas, comparada à Limeira. O ano de 2002 foi tomado como exemplo, por ser um ano em que há dados para todos os municípios avaliados e as tarifas do município de 
Limeira já cobriam os investimentos contratados, sendo que pode ser presumido que o equilíbrio financeiro estaria restabelecido.

\section{Tabela 4}

\section{Limeira e municípios de seu entorno. Despesas totais, despesas de exploração,} receitas e despesas com dívidas em 2002

\begin{tabular}{||l|r|r|r|r||}
\hline \hline Município & Receita (em R\$) & Despesas Totais (R\$) & \multicolumn{1}{c|}{$\begin{array}{c}\text { Despesas com } \\
\text { Exploração (R\$) }\end{array}$} & $\begin{array}{c}\text { Despesas com } \\
\text { Dívidas (R\$) }\end{array}$ \\
\hline Limeira & $30.213 .291,30$ & $33.428 .482,18$ & $12.217 .342,61$ & $7.846 .484,88$ \\
\hline Americana & $18.286 .695,66$ & $16.679 .407,24$ & $16.663 .567,56$ & $15.839,68$ \\
\hline Campinas & $189.334 .904,32$ & $199.544 .924,01$ & $129.386 .229,36$ & $30.357 .463,91$ \\
\hline Indaiatuba & $14.724 .920,00$ & $12.388 .788,00$ & $11.753 .610,00$ & $107.178,00$ \\
\hline Jundiaí & $44.027 .546,58$ & $45.147 .120,08$ & $35.472 .084,58$ & $1.053 .256,86$ \\
\hline
\end{tabular}

Fonte: SNIS. Diagnóstico 2002.

Organização: Cristiane F. de Oliveira

Apesar das diferenças inerentes à população demandatária, os municípios acima se encontram na mesma região administrativa - Campinas, com características de desenvolvimento econômico e de renda muito semelhantes, fatos estes que contribuíram para a escolha dos mesmos para ilustrar a dinâmica das empresas prestadoras de serviços de saneamento.

Cabe ainda esclarecer que a tabela contempla serviços prestados por empresas municipais, por meio dos Departamentos de Água e Esgoto, como é o caso de Americana e Jundiaí e por Serviço Autônomo de Água e Esgoto, no caso de Indaiatuba. Em Campinas os serviços são prestados por uma autarquia denominada Sociedade de Abastecimento de Água e Saneamento S.A. na qual a administração é pública e em Limeira os serviços são de responsabilidade da empresa privada Águas de Limeira.

Nota-se em todos os casos que a despesa de exploração é sempre inferior ao valor das receitas obtidas, o que implicaria em equilíbrio financeiro, caso não houvesse dívidas. Contudo, algumas dívidas são maiores do que outras e, quanto a isto, a análise da tabela acima destaca Limeira como o município que apresenta serviços com a segunda maior dívida, perdendo somente para o município de Campinas, que por sua vez é responsável pelo atendimento de uma população muito maior.

Deve ser observado que as despesas totais também são compostas por outros valores, correspondentes a encargos fiscais, tributários, amortizações e também por 
outras despesas não detalhadas. É importante informar que em 2002 a empresa Águas de Limeira contabilizou $\mathrm{R} \$ 10.673 .527,00$ como outras despesas.

Os serviços prestados pelo Departamento de Água e Esgoto de Americana e pelo Serviço Autônomo de Água e Esgoto de Indaiatuba foram os únicos que mantiveram as despesas totais e as receitas equilibradas.

Para os casos de Americana e de Indaiatuba as despesas de operação praticamente se equiparavam às despesas totais e as dívidas se mantiveram sob controle no ano analisado. Deve ser ressaltado ainda, que as tarifas aplicadas no mesmo ano por estas empresas foram as menores se comparadas às das demais empresas analisadas na tabela 4, sendo de respectivamente $\mathrm{R} \$ 0,63 / \mathrm{m}^{3}$ e $\mathrm{R} \$ 0,61 / \mathrm{m}^{3}$ para Americana e Indaiatuba, contra $\mathrm{R} \$ 0,82 / \mathrm{m}^{3}$ cobrados em Limeira, $\mathrm{R} \$ 0,84 / \mathrm{m}^{3}$ cobrados em Jundiaí e $\mathrm{R} \$ 1,32 / \mathrm{m}^{3}$ cobrado em Campinas.

Isto mostra que nem sempre as altas tarifas proporcionam equilíbrio financeiro às empresas operadoras.

Em relação aos anos subseqüentes (2003 e 2004) notamos que a empresa Águas de Limeira continuou a apresentar alto e crescente grau de endividamento e despesas de exploração dos serviços muito inferiores do que as despesas totais, conforme ilustra o gráfico a seguir.

\section{Gráfico 12}

Limeira. Evolução das Despesas Totais, Despesas de Exploração, Despesas com

Dívidas e Receitas entre 2002 e 2004. (R\$)

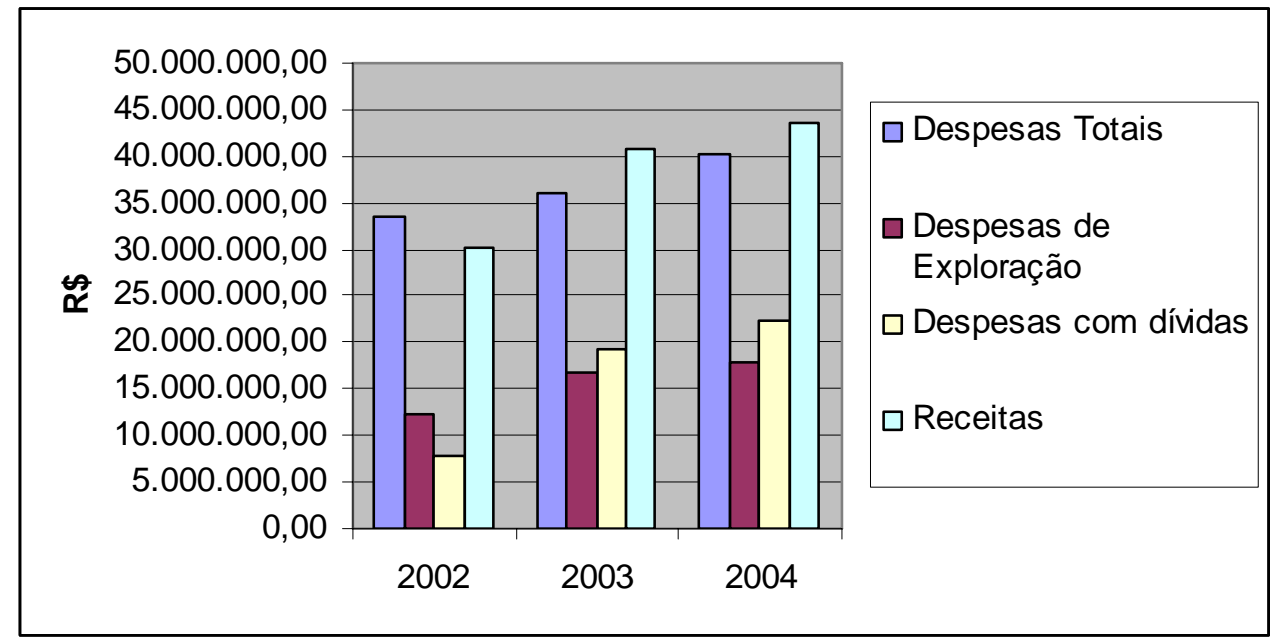

Fonte: SNIS. Diagnóstico dos Serviços de Água e Esgotos 2003 e 2004.

Organização: Cristiane F. de Oliveira 
Nota-se, também, que as despesas de exploração praticamente se mostraram inalteradas entre 2003 e 2004, enquanto que as receitas, advindas da cobrança de tarifas, são crescentes.

É importante esclarecer que as despesas de exploração incluem: despesas com pagamento de pessoal próprio, custos dos produtos químicos, custos de energia elétrica, pagamento de terceiros, despesas fiscais ou tributárias sobre os serviços e outras. Por sua vez, as despesas com dívidas incluem despesas com financiamentos, amortizações, juros e encargos, variação cambial e outras despesas não especificadas, que por sua vez, chegaram a alcançar em 2004 a soma de R\$ 15.499.986,00.

Também para o caso de Manaus esta lógica se aplica, conforme pode ser apreciada na tabela a seguir.

\section{Gráfico 13}

\section{Manaus. Evolução das Despesas Totais, Despesas de Exploração, Despesas com Dívidas e Receitas entre 2002 e 2004. (Em R\$)}

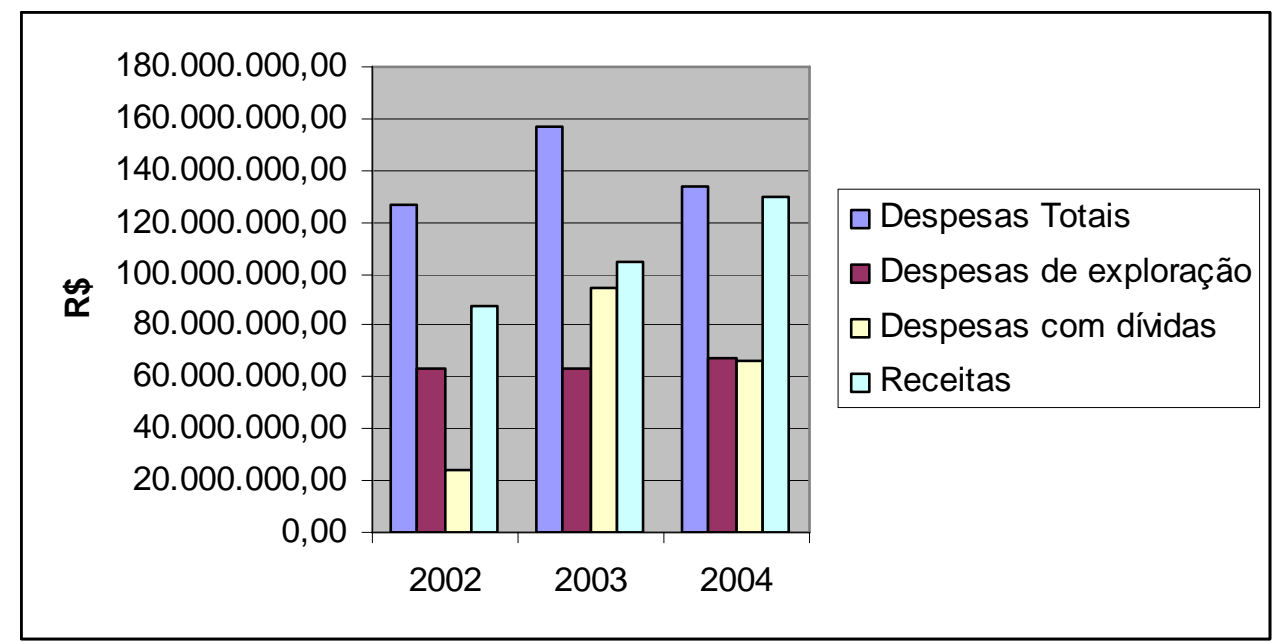

Fonte: SNIS. Diagnóstico dos Serviços de Água e Esgoto, 2002, 2003 e 2004.

Organização: Cristiane F. de Oliveira

É possível notar que até o momento as receitas não superaram as despesas totais. Contudo as despesas de exploração dos serviços sempre se mostraram inferiores ao valor das receitas e o desequilíbrio financeiro fica a cargo das despesas com as dívidas.

Deve ser ressaltado que apesar das dívidas serem elevadas os investimentos efetuados nos serviços, incluindo-se abastecimento de água e coleta de esgotos entre 2002 e 2004 não correspondem ao movimento do endividamento, como procura ilustrar o gráfico a seguir. 


\section{Gráfico 14 \\ Águas do Amazonas - Manaus. Relação entre investimentos e dívidas da empresa entre 2002 e 2004}

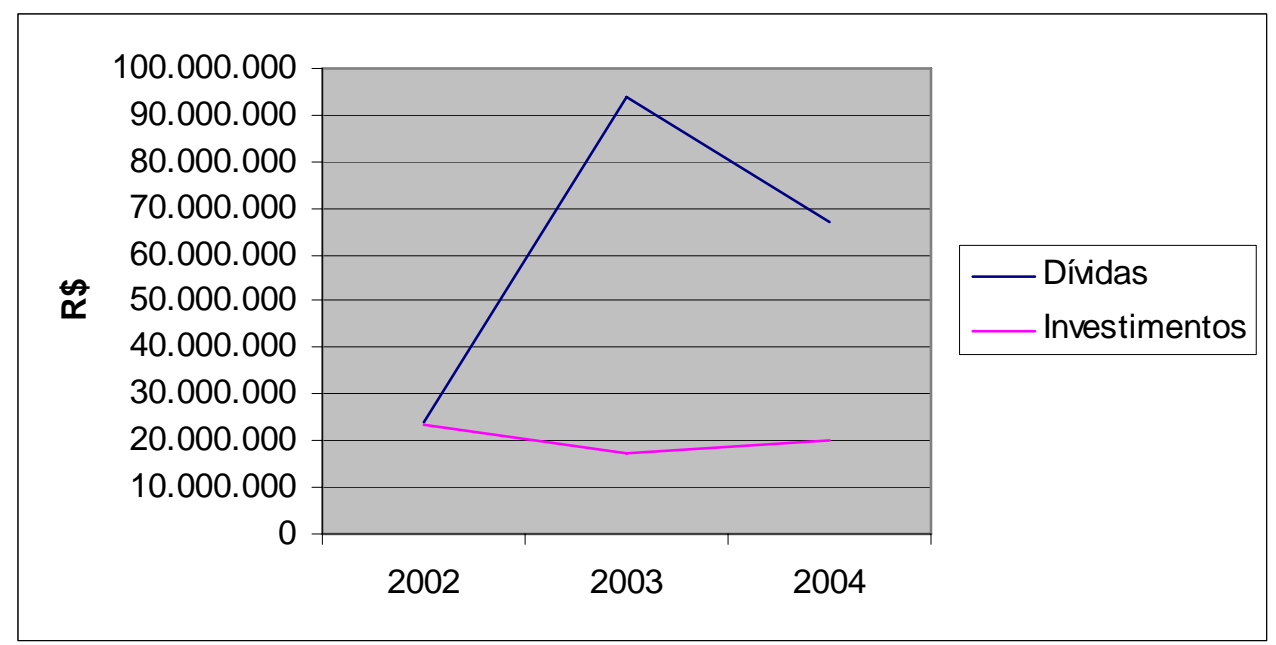

Fonte: SNIS. Diagnóstico dos Serviços de Saneamento de 2002, 2003 e 2004.

Enquanto os investimentos não ultrapassaram o patamar de R\$24 milhões as dívidas apresentadas por parte da empresa ultrapassam os $\mathrm{R} \$ 90$ milhões, com movimento inverso em relação ao período de crescimento das dívidas em relação aos investimentos.

Isto de certo modo, aponta para o fato de que as dívidas não estão relacionadas diretamente aos investimentos em serviços, mas podem estar comprometidas com as transações financeiras do grupo.

A fonte de análise possível sobre as transações financeiras das empresas em questão se encontra nos balanços financeiros divulgados. Contudo, como ressalta Marques (2004) os fundamentos contábeis nem sempre são dispostos de forma coerente e detalhados já que a legislação brasileira abre esta possibilidade.

Neste sentido, os passivos circulantes constantes nos balanços patrimoniais nos dão uma idéia sobre as negociações entre empresas coligadas e de seus montantes e quanto a isto é possível obtermos os nomes das empresas com as quais houve envolvimento financeiro e, de certo modo os montantes envolvidos.

No que se refere ao balanço patrimonial da empresa Águas de Limeira para os anos 2002, 2003 e 2004, é possível observar que as negociações ocorrem sempre envolvendo empresas do grupo, conforme a tabela a seguir: 
Tabela 5

Balanços patrimoniais da empresa Águas de Limeira. Evolução do passivo circulante e despesas e receitas financeiras entre 2002 e 2004

\begin{tabular}{|l|c|c|c||}
\hline $\begin{array}{l}\text { Tipo de Passivo Circulante e empresas } \\
\text { relacionadas }\end{array}$ & 2002 & \multicolumn{2}{|c|}{2003} \\
\hline Empréstimos (contratos de mútuos) & & & \\
(Negócios em milhares de R\$)
\end{tabular}

Fonte: Demonstrações Financeiras da empresa Águas de Limeira em 31/12/02, 31/12/03 e 31/12/04.

É possível notar grande grau de endividamento, por tomada de empréstimos ou comprometimento das contas com pagamento de serviços de terceiros às empresas do próprio grupo.

A empresa Águas do Amazonas opera da mesma forma, podendo ser observado na tabela a seguir que as empresas com as quais manteve negócios entre 2002 e 2004 fazem parte também do mesmo grupo econômico. 


\section{Tabela 6 \\ Empresa Águas do Amazonas. Evolução das Demonstrações Financeiras entre} 2002 e 2004

\begin{tabular}{||l|r|r|r||}
\hline $\begin{array}{l}\text { Tipo de Passivo e empresas } \\
\text { relacionadas }\end{array}$ & \multicolumn{3}{|c||}{$\begin{array}{c}\text { 2003 } \\
\text { Negócios em milhares de R\$ }\end{array}$} \\
\hline DSPV Empreend.e Participações S.A. & 2.480 & - & - \\
D.R.M.A. Empreend.e Participações S.A. & 1.600 & 4.050 & - \\
Ondeo Services & 41 & 29 & - \\
Ondeo Services Brasil Ltda. & 48 & 1.284 & - \\
Ondeo Services França & 2.834 & 2.791 & - \\
Águas de Illimani & 102 & 91 & - \\
Ondeo Degremont Ltda. & 2.838 & 1.684 & - \\
Ondeo Services - América Latina & 49 & 41 & - \\
Ondeo Nalco do Brasil Ltda. & 21 & - & - \\
Suez Environnement S.A. & - & 54.857 & 7.013 \\
Suez Ambiental S.A. & - & 1.405 & 1.396 \\
Vega Enga . Ambiental S.A. & - & 1.540 & 5.667 \\
Ondeo Services Filipinas & & 202 & - \\
& & & \\
\hline
\end{tabular}

Fonte: Demonstrações financeiras da empresa Águas do Amazonas no período envolvido entre 2002 e 2004.

Nota-se também envolvimento de várias empresas do grupo Suez S.A. em altos valores de transações com as empresas Águas de Limeira e Águas do Amazonas. Não é possível afirmar que os valores envolvidos nas transações entre empresas são responsáveis totalmente pela dívida, mas há indícios a este respeito.

Estas transações financeiras entre empresas do mesmo grupo movimentaram um montante de cerca de R\$10 milhões em 2002, de quase R\$64 milhões em 2003 e, de aproximadamente R\$ 14 milhões em 2004.

Quando associamos o montante destas dívidas a reformulação da Lei 8.987 de 13 de fevereiro de 1995 que trata das concessões, por meio das disposições finais apresentadas no Projeto de Lei 7361/06 a lógica parece ser esclarecida. O parágrafo $5^{\circ}$ acrescentado à lei 8.987, define as formas e o que deverá ser indenizado pelo poder concedente, quando ocorrer o término ou a rescisão do contrato de concessão. Deste modo, procuramos reproduzir a seguir os termos deste artigo:

$\S 5^{\circ}$ No caso do §4, o pagamento de eventual indenização será realizado, mediante garantia real, por meio de quatro parcelas anuais, iguais e sucessivas, da parte ainda não amortizada de investimentos e de outras indenizações relacionadas à prestação dos serviços, realizados com capital próprio do concessionário ou de seu controlador, ou originários de operações de financiamento, ou obtidos mediante emissão de ações, debêntures e outros títulos 
mobiliários[grifo nosso], com a primeira parcela paga até o último dia útil do exercício financeiro em que ocorrer a reversão. ${ }^{45}$

Deve ser notado que todos investimentos, até mesmo aqueles não computados como imobiliário contam no processo indenizatório. Neste sentido, todas as dívidas acumuladas podem ser contabilizadas em um possível processo de indenização, inclusive as que integram as operações de financiamento, tal como mencionado na referida lei. A manutenção de altos níveis de endividamento, portanto, seriam interessantes de várias formas, para encobrir fluxos negativos de caixa, como já lembrado por Justo (2004) e para obtenção de altas indenizações quando for conveniente.

Os resultados da opção pelo crescimento do grupo em detrimento do desenvolvimento efetivo das atividades assumidas pelas empresas subsidiárias, são especialmente graves para as populações que dependem ou aguardam ser atendidas pelos serviços.

Neste sentido, devido à insuficiência de redes de abastecimento de água e de esgotos, bem como devido à ausência de adequado tratamento de esgoto a saúde pública é deteriorada, as economias que dependem dos serviços de saneamento se retraem e a poluição dos cursos d’água amplia-se, comprometendo o meio ambiente e agravando ainda mais as precárias condições de vida de grande parte das populações envolvidas.

Quando os serviços de saneamento básico são insuficientes e agravam as condições de vida locais, o Estado é onerado, implicando em maiores custos com saúde, custos com auxílios sociais e com recuperação ambiental.

O que deve ficar claro é que a retirada do Estado, das atividades de prestação dos serviços de saneamento básico nem sempre corresponde à melhoria da qualidade do atendimento ou ao aumento dos investimentos em ampliação das redes e da cobertura dos serviços. Ainda, sua retirada também não implica em diminuição de ônus para o setor público, já que ele continua responsável pelas conseqüências da falta de investimentos, seja qual for o prestador dos serviços e também continua responsável pelo ônus advindo das indenizações às concessionárias privadas.

Neste sentido, foi possível observar que o Estado, por meio de suas instâncias de governo e órgãos públicos relacionados à prestação dos serviços de saneamento básico,

\footnotetext{
${ }^{45}$ BRASIL. Projeto de Lei n.7361/06. Aprovado pela Câmara do Senado em 12/12/2006. Estabelece diretrizes nacionais para o saneamento básico e dá outras providências.
} 
pode ser bem sucedido na prestação dos serviços de saneamento básico, apesar das dificuldades financeiras pelas quais passa.

Por outro lado, apesar de não haver uma regra para a atuação da iniciativa privada neste setor, como exposto por Vargas e Lima (2004, p.77), os riscos de comprometimento dos serviços em razão dos objetivos prioritários da iniciativa privada, de rápido alcance do lucro e de grande rentabilidade, especialmente por parte de grandes grupos econômicos, são altos.

O Estado por sua vez, devido à heterogeneidade de interesses que o conformam, também está sujeito ao desenvolvimento de políticas públicas de saneamento básico que nem sempre alcançam o cumprimento da essência do serviço público, como já definido. Deste modo, em grande parte as populações mais pobres são as mais atingidas pelas falhas ou pelas ausências dos sistemas projetados.

Devido à fragilidade do capital social envolvido diretamente, ou seja, devido à ausência de grupos ou representações que possam acompanhar as ações políticas e administrativas e exigir o cumprimento da defesa do interesse público é que a atuação da iniciativa privada surge como alternativa à ação da iniciativa pública.

Apesar da iniciativa privada comportar grande heterogeneidade, sendo capaz também de repassar tecnologias avançadas e mesmo de conduzir ações de cunho ambiental desenvolvidas nos países de origem, como observado por Guedes (2000), estas ações dependem também de cobrança da sociedade civil. Como ressalta Guedes “os incentivos para que boas práticas sejam estabelecidas em parceria entre empresas e governos decorrem de pressões dos consumidores e da opinião pública”46.

Na ausência desta força de cobrança a prioridade dos grandes grupos econômicos é a de ampliar ainda mais seu capital. A forma mais rápida e eficiente tem se apoiado nas transações financeiras com forte centralização do capital por meio das aquisições, incorporações ou fusões e por meio das negociações financeiras entre empresas do mesmo grupo.

A água é vista por parte destes grupos como elemento de marketing utilizado para conquistar novos espaços de atuação e por meio destes possibilitar a reprodução ampliada do capital.

Como pudemos discutir, a atuação das subsidiárias no âmbito local promove as estratégias do grupo por meio das negociações entre empresas coligadas e por meio de

\footnotetext{
${ }^{46}$ GUEDES, Ana Lúcia. Repensando a nacionalidade das empresas transnacionais. In: Revista de Sociologia e Política n.14, jun. 2000, p.53.
} 
pressões para obtenção de constantes aumentos tarifários. Estas ações são priorizadas em detrimento dos investimentos necessários ao pleno atendimento das necessidades dos usuários, que seria o de alcance dos preceitos básicos dos serviços públicos envolvidos, ou seja, o alcance da universalização do acesso aos serviços, da equidade, da continuidade no atendimento e da modicidade das tarifas.

No Brasil, a estrutura reguladora dos serviços de saneamento está sendo delineada com o Projeto de Lei n.7361 de 2006, tendo sido remetida à sanção pela Presidência da República em dezembro deste mesmo ano. Contudo, apesar de alguns autores como Bishop (1988) e Swann (1988) já terem ressaltado a importância de uma estrutura reguladora adequada ao pleno desenvolvimento das atividades de saneamento básico, como forma de reduzir as fragilidades do Estado, nota-se ainda outras pendências não solucionadas com a criação da nova Lei.

Entre estas pendências é evidente a necessidade de autonomia econômica das agências reguladoras, que se choca com a realidade econômica do país. Como fazer para que o regulador não seja capturado pelo regulado, se o primeiro é amparado financeiramente pelo segundo? Esta sem dúvida é uma questão essencial para que as medidas propostas no Projeto de Lei mencionado possam ser implementadas na prática.

Neste sentido, apesar do Projeto de Lei procurar definir critérios para a atuação e tornar mais transparentes as regras para a prestação dos serviços de saneamento básico, não foram ainda definidos os meios para o alcance da autonomia esperada. Ainda, não se nota um envolvimento aprofundado da sociedade na discussão desta temática, abrindo-se brechas para a atuação de interesses distintos ao do desenvolvimento de um sistema de saneamento básico acessível à toda sociedade.

Se por um lado, representantes da iniciativa privada estão organizados em diversas frentes, posicionando-se em pontos chaves para a formulação de políticas públicas do setor, com participação em colegiados, em associações de classes ou com estreita articulação com agências unilaterais, os demais elementos da sociedade civil carecem de organização para efetiva participação no processo de decisão.

Como resultado disto nota-se o avanço dos interesses privados em detrimento dos interesses públicos e um afastamento entre sociedade e Estado. 
Como lembra Jacobi a educação é a ferramenta capaz de reverter este quadro, já que conforme o autor é ela que possibilita o resgate da cidadania, o que "coloca a sociedade em contato com o Estado" ${ }^{47}$.

Deste modo, a luta pelo alcance da cidadania e consequentemente da capacidade de participação organizada da sociedade civil requer a atuação do Estado também no fortalecimento das políticas educacionais. A educação possibilita a conscientização sobre os direitos de cada indivíduo e, portanto, é um instrumento de luta para a inclusão.

É importante destacar que o conceito de cidadania para Pinsky (2003), está relacionado aos direitos civis, políticos e sociais, direitos estes que, segundo Singer (2003) são obtidos com muita luta, com vitórias e derrotas, avanços e retrocessos, marcados pela história de cada lugar e de cada sociedade.

Ainda, segundo Singer (2003, p.260) é importante notar que no Brasil, o Estado tem abandonado paulatinamente sua responsabilidade em estender os direitos sociais, na qual se pode destacar o acesso aos serviços de saneamento básico. Isto se deve, segundo o autor, às crises econômicas que geraram grande estagnação e dificuldade de financiamento dos gastos sociais, crises estas impostas pela hegemonia neoliberal e pelo capital financeiro.

O que se nota, ainda no caso brasileiro, é um Estado caracterizado por grande fragilidade institucional, com limitada capacidade de governança, o que tem contribuído para a manutenção do status quo e perpetuação dos déficits nos serviços públicos.

Deve-se ressaltar que a capacidade de governança é aqui compreendida, conforme destacado por Azevedo e Guia (2000, p.140), como a capacidade de intermediação de interesses, em especial daqueles envolvendo a participação da sociedade civil quanto à formulação e aplicação das políticas públicas, superando-se o aspecto puramente administrativo.

Ainda, a limitação na capacidade de governança tem promovido o afastamento entre Estado e sociedade, resultando no aprofundamento dos contrastes sociais e no enfraquecimento do próprio Estado que por sua vez encerra um ciclo vicioso que mantém a estrutura de exclusão aos direitos sociais inalterada.

Diante do exposto, é importante frisar que a efetivação de um marco regulatório por si só não permite definir concretamente o futuro do setor de saneamento básico no Brasil, apenas delineia os caminhos que devem ser seguidos.

\footnotetext{
${ }^{47}$ JACOBI, Pedro Roberto. Educação, ampliação da cidadania e participação. São Paulo: Educação e Pesquisa. Vol.26. n², Jul/Dez. de 2000.
} 
Quanto a possível expansão dos grandes grupos transnacionais em território brasileiro em função da regulação do setor, não há possibilidade de previsão. Por um lado a regulação do setor reduz os riscos da iniciativa privada, já que a atuação do Estado se torna mais transparente e previsível. Por outro, a estrutura mais rígida de controle e fiscalização, caso efetivada, pode afastar aqueles que buscam retorno financeiro rápido.

De qualquer modo a atuação de grandes grupos transnacionais em território brasileiro a exemplo do Suez S.A. já é fato consumado, o que nos permite afirmar que independentemente da estrutura reguladora adotada, as estratégias de ampliação do capital estão consolidadas por meio da captura da valorização seletiva das diferenças espaciais.

Segundo Becker a valorização seletiva da diferença seria o meio pelo qual "a globalização da economia-mundo avança"48.

Neste trabalho a captura da valorização seletiva ocorre quando é concedido o direito de exploração dos serviços de saneamento básico em áreas de grande ocorrência de água, como é o caso de Manaus e de Limeira, já que no âmbito mundial a idéia de escassez deste bem corroborou sua transformação em grande negócio.

Finalmente, além da captura da valorização seletiva a forma de atuação do grupo Suez S.A. configura também estratégias de reprodução ampliada do capital apoiadas principalmente no sistema financeiro.

Os resultados desta atuação são sentidos principalmente no âmbito local e por parte das populações mais empobrecidas. Neste sentido, procuraremos no próximo capítulo analisar a atuação das empresas Águas de Limeira e Águas do Amazonas ligadas ao grupo Suez S.A. no que concerne ao atendimento das demandas pelos serviços, à qualidade dos serviços e também no que concerne a percepção dos usuários quanto ao atendimento de suas demandas.

\footnotetext{
${ }^{48}$ BECKER, BERTA K. A (Dês) ordem global, o desenvolvimento sustentável e a Amazônia. In: BECKER, B.K. et al. (Orgs.) Geografia e Meio Ambiente no Brasil. São Paulo: Hucitec/Annablume, 2002.p.49.
} 


\section{CAPÍTULO III}

A atuação do grupo Suez no saneamento básico no Brasil - Os casos de Manaus e Limeira 
Procuramos neste capítulo analisar a relação entre a privatização e a evolução da prestação dos serviços de saneamento básico em Limeira-SP e em Manaus-AM. Esta análise busca contribuir para uma melhor compreensão sobre as finalidades da privatização dos serviços e sobre os impactos da privatização no âmbito local.

Para alcançar os objetivos deste capítulo procuramos na primeira parte discutir, de forma sucinta como ocorre a articulação público-privado na gestão do espaço urbano, no que tange às questões relacionadas ao saneamento básico e as implicações destes serviços na dinâmica das políticas urbanas e ambientais em Manaus e Limeira.

Na segunda parte procuramos analisar, de forma retrospectiva, os serviços nestas duas cidades, avaliando os avanços e os retrocessos ocorridos devido à concessão dos serviços à iniciativa privada.

Entre os elementos analisados constam os dados divulgados pelo Sistema Nacional de Informações sobre Saneamento, dados do IBGE, que nos auxiliam na construção do panorama evolutivo da prestação dos serviços no que concerne, sobretudo aos investimentos em rede de infra-estrutura.

As metas previstas nos contratos de concessão, por fornecerem parâmetros para avaliação da efetividade das ações, foram consideradas também em nossas análises.

As informações do SNIS propiciaram a análise evolutiva dos serviços de saneamento básico, tendo sido incorporados dados divulgados desde 1995 até 2004 sobre índices de cobertura de abastecimento de água, coleta e tratamento de esgotos, extensão das redes, volumes de água tratados, consumo, perdas, tarifas, etc.

Tendo em vista que as informações do SNIS são oriundas de informações apresentadas pelas empresas prestadoras de serviços, buscamos obter, também, informações a partir de pesquisa de campo sobre a qualidade da água e sobre a percepção dos usuários no que concerne ao atendimento de suas demandas por serviços de saneamento básico.

A análise do atendimento das demandas, portanto, foi amparada nos dados divulgados pelo SNIS e a partir de questionários aplicados a amostras da população envolvida.

Estes questionários tiveram por finalidade fornecer indícios sobre: a cobertura da rede de água e esgoto, a qualidade da água consumida, o custo das tarifas para a população, a ocorrência de doenças possivelmente veiculadas por água e a existência de campanhas educativas de economia de água. 


\section{A articulação público-privado e as políticas públicas de saneamento básico}

Inseridas na concepção de saneamento ambiental as políticas de saneamento básico estão fortemente ligadas às políticas urbanas e ambientais, bem como, consequentemente, às políticas de saúde.

A ausência de saneamento básico em aglomerações urbanas não só compromete o meio ambiente e os recursos disponíveis, mas também deteriora a saúde das populações que depende deste meio e destes recursos.

Durante as discussões desenvolvidas no capítulo anterior pudemos resgatar como ocorreu a transferência, na década de 70, da competência pela operação dos serviços de saneamento básico das instâncias municipais para as instâncias estaduais, representadas pelas companhias estaduais.

Como os financiamentos do Sistema Nacional de Saneamento foram direcionados somente às companhias estaduais, a única forma de muitos municípios poderem captar estes financiamentos e desenvolver os serviços de saneamento básico foi pela via da concessão, ou seja, concedendo a responsabilidade de operação às companhias estaduais. Esta medida, entre outras, contribuiu para que se aprofundasse uma grande setorialização entre as instâncias públicas, fato este observado por Silva (1999).

Enquanto as decisões relativas às políticas públicas urbanas, ambientais e de saúde ficaram a cargo da municipalidade, as decisões sobre investimentos e desenvolvimento dos serviços de saneamento básico, entre a década de 70 e 90 ficaram, principalmente, sob responsabilidade das companhias estaduais, que como lembra Britto (2001) focaram esforços prioritariamente na ampliação do acesso à água em detrimento da coleta e do tratamento de esgotos. A opção pelo desenvolvimento dos serviços de abastecimento de água, segundo a mesma autora, se deveu ao fato de que era a atividade mais lucrativa, de retorno financeiro mais rápido, já que envolvia cobrança pelo consumo.

Este fato contribuiu fortemente para a deterioração de grande parte dos recursos hídricos brasileiros, em especial daqueles situados em áreas mais adensadas como nas grandes cidades, já que os esgotos não tratados são lançados nos cursos d’água, ou infiltram no solo, atingindo lençóis subterrâneos, contaminando-os.

Os riscos de contaminação de lençóis freáticos são altos em áreas densamente ocupadas. Nestas áreas, quando há ausência de redes de saneamento básico é comum o 
uso de fossas sépticas ou fossas negras que, não raro, são atingidas por recalques dos lençóis em períodos de grande pluviosidade, provocando o contato da água contaminada com a água dos lençóis. Também, nestas áreas, a falta de espaço, provoca a perfuração de poços muito próxima das fossas, que também contribui para o risco de contaminação da água.

A água contaminada, por sua vez, é um risco para as populações, estejam estas situadas em locais mais próximos dos pontos de poluição ou situadas em pontos mais distantes. O contato direto pode ocorrer quando ocorrem enchentes, ou indireto quando se consome água de fontes contaminadas ou alimentos também produzidos com uso de água contaminada.

Os problemas de saúde relacionados à iniqüidade na oferta de serviços públicos atingem principalmente as populações mais pobres, como observado por Ribeiro (2005), mas no que se refere às doenças veiculadas pela água a abrangência da população afetada pode ser ainda maior.

Deste modo, enquanto as companhias estaduais optaram por postergar os investimentos necessários em coleta e tratamento de esgotos, as municipalidades foram obrigadas a conviver com os custos da deterioração ambiental e de saúde, provocada pelos déficits acumulados destes serviços.

Em Manaus os déficits acumulados de coleta e tratamento de esgotos resultaram em grande comprometimento dos cursos d’água superficiais, que permeiam a área urbana, bem como dos poços de água.

Em relação ao comprometimento dos cursos d’água em Manaus, de acordo com pesquisa elaborada pela Fundação Oswaldo Cruz (Fiocruz) e publicada pela Revista da FAPESP (2005), foram verificados nos igarapés da cidade grande concentração de bactérias. Segundo esta extensa pesquisa sobre qualidade das águas nos igarapés de Manaus, as bactérias encontradas, em grande concentração, podem provocar sérios riscos à saúde, especialmente se ingeridas com a água contaminada. Dentre as bactérias isoladas constam a Salmonella spp, a Escherichia coli e a Klebsiella pneumoniae, todas agressivas ao organismo humano.

Os serviços saneamento básico, por seu caráter de essencialidade e por interferirem fortemente no desenvolvimento das atividades econômicas e na saúde pública, exigem políticas que possam ser articuladas às outras políticas, como a urbana, a de saúde e à econômica, bem como exigem políticas que possam ser articuladas em diferentes instâncias (municipal, estadual e federal). A elaboração destas políticas e sua 
articulação é uma tarefa complexa, que requer a definição de interesses comuns e o desenvolvimento de esforços conjuntos e complementares.

Deste modo, procurando compreender melhor as causas dos déficits deixados no setor de saneamento básico em Limeira e em Manaus e em especial, no atendimento das demandas por coleta e tratamento de esgotos, é que procuramos analisar, além da evolução dos serviços, o desenvolvimento das políticas públicas de saneamento básico e sua articulação com outras políticas a ela estreitamente ligadas.

Para que possamos compreender melhor a articulação entre as políticas públicas e a atuação privada no setor de saneamento básico faz-se necessário resgatarmos, caso a caso, a situação de cada município em questão.

\subsection{As políticas de saneamento básico em Manaus}

De acordo com Andrade (1994), Manaus se situa à margem esquerda do rio Negro, distando cerca de 20 km da confluência com o rio Solimões.

O rio Negro é o principal e maior afluente do rio Amazonas situado na Bacia hidrográfica do mesmo nome, o qual concentra o maior volume de água doce superficial do mundo.

De pequeno arraial Manaus chegou à vila ${ }^{49}$ em 1833. Como é sabido, grande desenvolvimento se deu com a exploração da borracha entre 1890 e 1920 quando a cidade prosperou e foram efetuadas grandes obras públicas, entre elas a de rede de esgotos e canalizações de água. Com o final deste ciclo econômico, houve grande estagnação de investimentos em infra-estrutura urbana que perdurou até que a década de 1970, quando houve a criação da Zona Franca de Manaus e novo impulso econômico seguido de grande crescimento populacional. O gráfico a seguir mostra a evolução demográfica de Manaus entre 1960 e 2002, que permite dimensionar a necessidade de expansão dos serviços de saneamento básico.

\footnotetext{
${ }^{49}$ Como vila recebeu o nome de Manaós em homenagem a tribo de mesma denominação que resistira a escravidão.
} 
Gráfico 15

Manaus. Evolução demográfica entre 1960-2002.

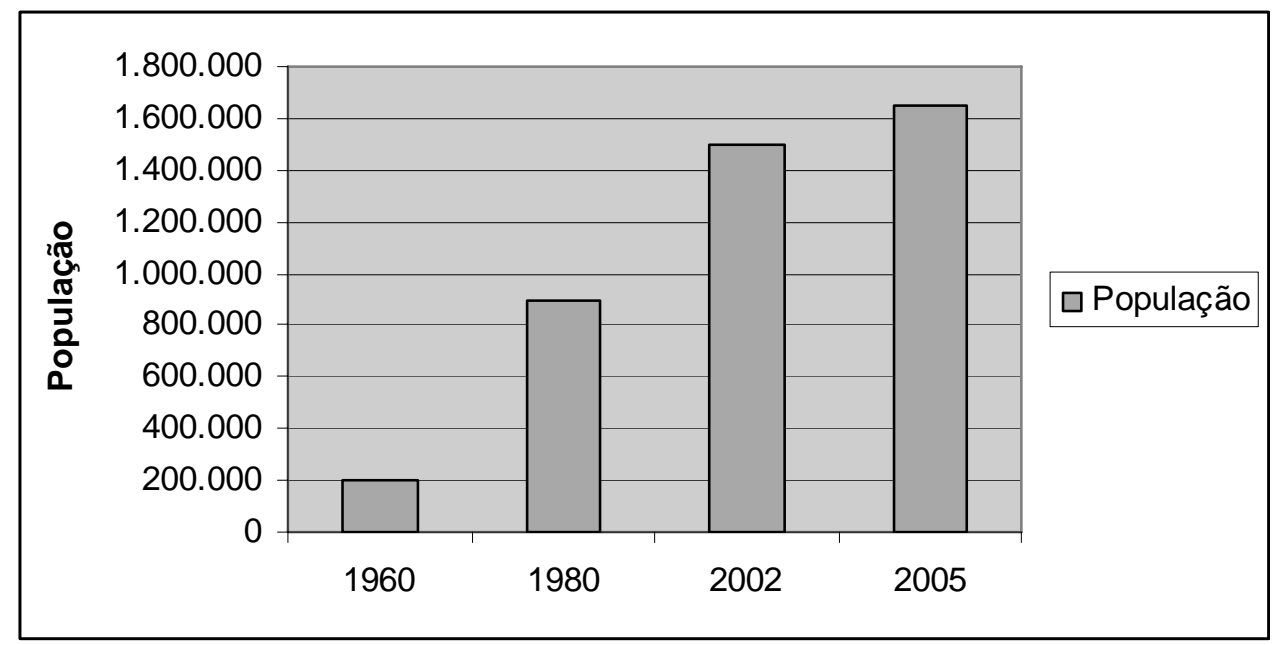

Fonte: IBGE

A maior parte da população urbana de Manaus se concentra na parte sul e Sudoeste da cidade, em torno da área de ocupação mais antiga e ao longo do rio Negro.

Deve ser observado que a área reservada para a adução de água se situa no bairro Compensa de n.10 no mapa a seguir, às margens do rio Negro na porção Sudoeste da cidade de Manaus. Isto explica de certo modo, os índices mais altos de abastecimento no entorno desta área.

O tratamento da água e distribuição em rede é feito por meio de dois sistemas o denominado Estação de Tratamento de Água - ETA Ponta do Ismael, localizado no bairro Compensa e o denominado ETA Mauazinho, situado na porção sudeste do município, também as margens do rio Negro.

Os serviços de abastecimento de água também dependem de poços isolados, situados em áreas mais distantes das ETA Ponta de Ismael e Mauazinho. A partir da exploração destes poços a água segue por redes aos reservatórios públicos e depois por redes é distribuída aos usuários. Ainda, há sistemas mistos, na qual a água aduzida do rio Negro e de poços é reservada, seguindo por meio de rede ao consumidor.

Segundo a empresa Águas do Amazonas a ETA Ponta de Ismael é responsável por $80 \%$ da água que é distribuída em rede, a ETA Mauazinho responde por 4\% e os sistemas isolados de poços e misto respondem por 16\% da água distribuída.

Todos estes casos serão considerados como integrantes do sistema de abastecimento em rede. 
A porção sudoeste da cidade é aquela mais bem atendida pelos serviços de saneamento básico, já que se encontra mais próxima à principal área de adução de água, a ETA Ponta de Ismael, situada no bairro Compensa. Por conseguinte, as áreas mais distantes desta área, situadas principalmente na porção Norte e Nordeste e Leste da cidade são as mais precárias em extensão das redes e quanto à intermitência de abastecimento de água.

Em 2004 a cidade de Manaus abrigava 56 bairros, sendo que entre eles, Tarumã, Ponta Negra, Distrito Industrial I e II e Purarequara, situados nas periferias Noroeste e Nordeste, apresentavam fortes características rurais e baixa cobertura de água por rede.

Deve-se observar que o bairro Distrito Industrial I e II, que abriga grande parte do parque industrial existente em Manaus, apesar de apresentar baixo índice de cobertura de água, se sustenta por meio de sistemas isolados particulares, ou seja, por meio de poços profundos (artesianos ou semi-artesianos). É importante lembrar que algumas pequenas ocupações urbanas, situadas no entorno deste parque industrial, por vezes, é beneficiada com a oferta de água advinda dos poços das indústrias aí localizadas.

Segundo o IBGE, Manaus possui baixos índices de cobertura de rede de esgoto, não alcançando 50\% em toda a área urbana e a rede existente se concentra próxima a ETA Ponta de Ismael, no Sudoeste e Centro da cidade.

O mapa a seguir procura apresentar a divisão da cidade de Manaus, por bairros e o índice médio de abastecimento de água e de coleta de esgoto em cada bairro. 
Mapa 3. Manaus - Índice de distribuição de água e esgoto segundo a localização dos bairros (2000)

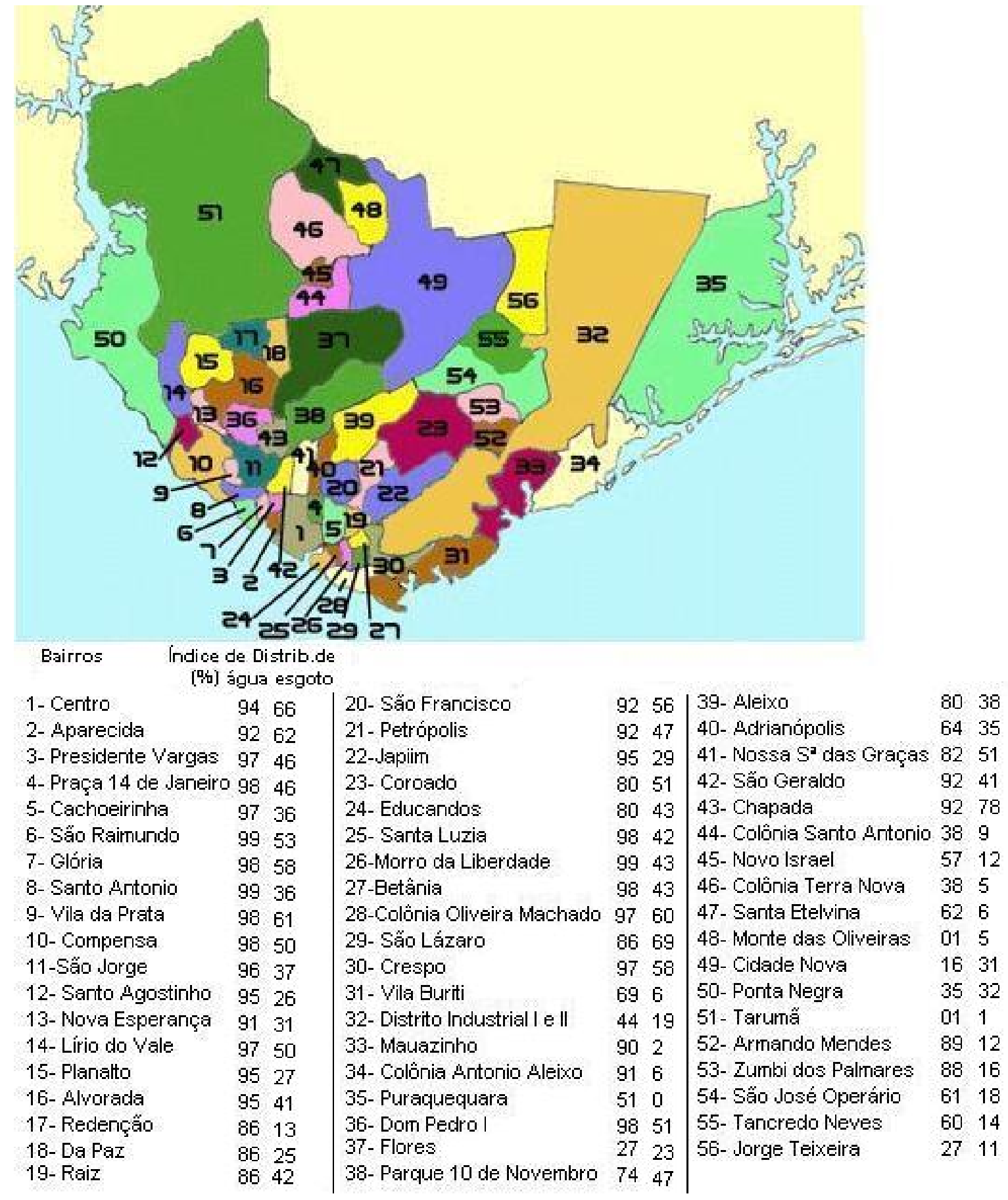

Fonte: SIDRA/IBGE/2000.

Organização: Cristiane F. de Oliveira 
A partir desses índices divulgados pelo IBGE mapeamos as áreas mais bem atendidas por abastecimento de água, as áreas intermediárias, onde o abastecimento de água cobre entre $50 \%$ e $79 \%$ da população e as áreas em que estes serviços de saneamento básico ainda são insuficientes para atender as demandas.

\section{Mapa 4}

\section{Manaus. Cobertura de abastecimento de água por bairros em 2000}

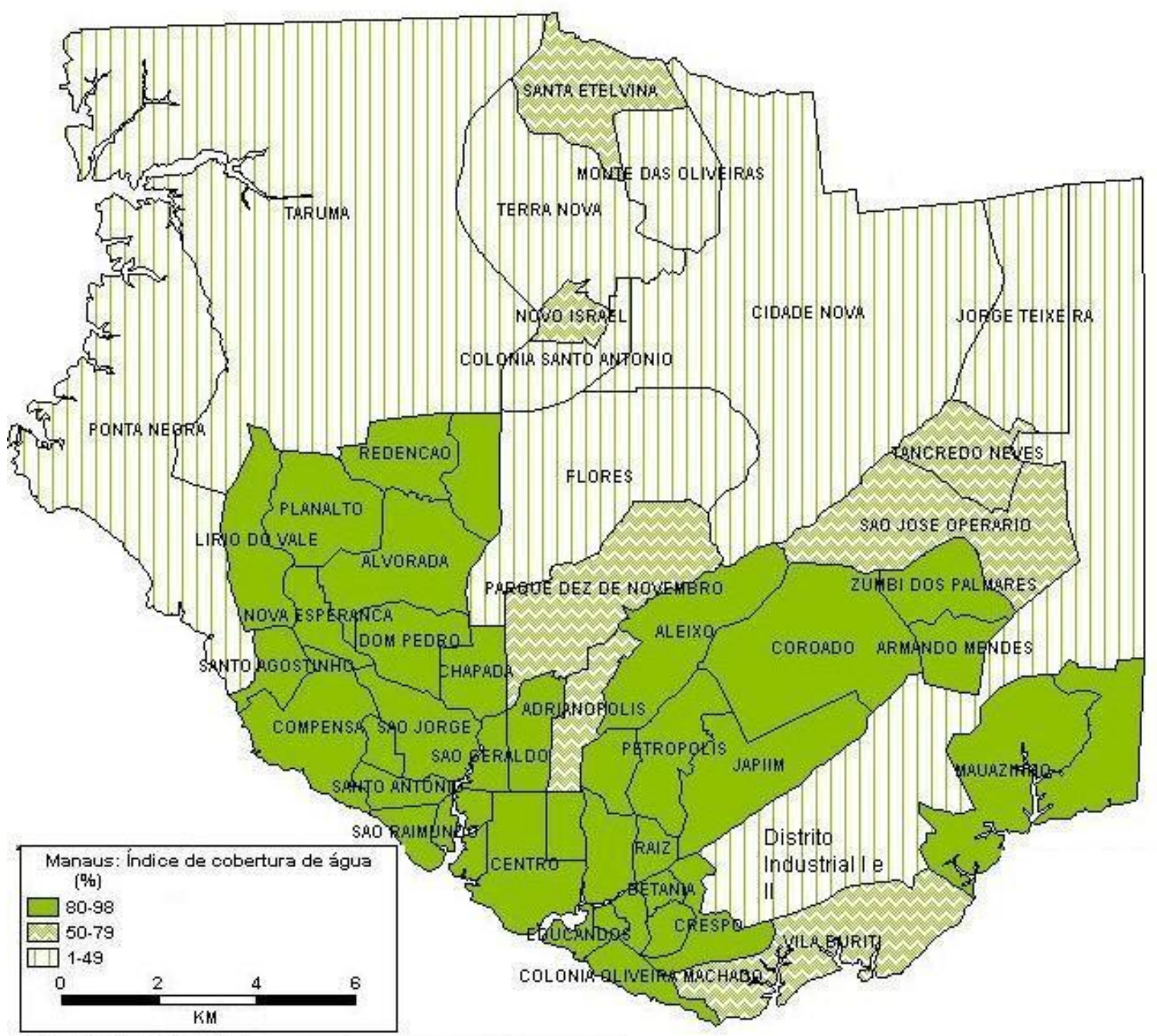

Fonte: Dados: IBGE/SIDRA

Base Cartográfica: Prefeitura do Município de Manaus 
É importante destacar que, segundo o IBGE, em 2000, os bairros com o maior número de domicílios na cidade de Manaus eram os bairros Cidade Nova, que apresentava 46.301 domicílios, o bairro São José Operário, com 19.507 e Jorge Teixeira com 17.813. De acordo com o mapeamento elaborado estes bairros, mais povoados, apresentam baixa cobertura de saneamento básico.

Nota-se que as porções Norte, Nordeste e Noroeste são aquelas com menor cobertura de água. Mesmo assim, entre a década de 1970 e 1980, conforme dados publicados pela Prefeitura Municipal de Manaus, houve grande número de aprovações de novos loteamentos justamente nessas áreas pouco servidas por serviços de saneamento básico, que incluem principalmente os bairros: Parque 10 de novembro, Cidade Nova e Ponta Negra. Dentre estes, somente o bairro de Ponta Negra apresenta características diferenciadas dos demais.

Este último apresenta altos padrões de construção, apoiados em infra-estrutura de saneamento básico com sistemas isolados.

O bairro de Ponta Negra (na região Oeste do município) se destaca dos demais bairros de Manaus, quase como um enclave, pela exclusividade de condomínios (verticais e horizontais) de alto padrão de construção. Neste bairro também se concentram grandes hotéis, como o Tropical e toda a infra-estrutura voltada para atender a classe turística economicamente mais rica.

Quanto ao padrão de construção, a cidade de Manaus é bastante heterogênea e, com poucas exceções, não há uma clara predominância de construções de alto padrão ou baixo padrão em grande parte dos bairros.

O crescimento da área urbana do município tem ocorrido, principalmente, no sentido Leste - Nordeste, acompanhando as vias de deslocamento principais, como a Estrada Torquato Tapajós (em sentido Sul-Norte) e as vias secundárias já existentes e em construção que desta derivam. Pudemos desta forma, observar grande adensamento populacional em bairros novos, como Cidade Nova, Colônia Terra Nova, Santa Etelvina e Monte das Oliveiras. Adensamentos estes, porém, não acompanhados de estrutura urbana adequada, como de saneamento básico, como relataremos mais à frente.

As políticas urbanas, como a de planejamento e controle do uso do solo urbano não têm obtido sucesso, e não raramente ocorrem medidas “eleitoreiras”, como abertura de novas vias em áreas que não deveriam ser adensadas ou mesmo a aprovação de 
novos loteamentos ${ }^{50}$ e conjuntos habitacionais em bairros ainda desprovidos, em grande parte ou totalmente, de serviços de saneamento básico.

O mapa a seguir procura ilustrar a espacialização da mancha urbana do município de Manaus.

\section{Mapa 5}

\section{Manaus. Ocupação urbana em 2000}

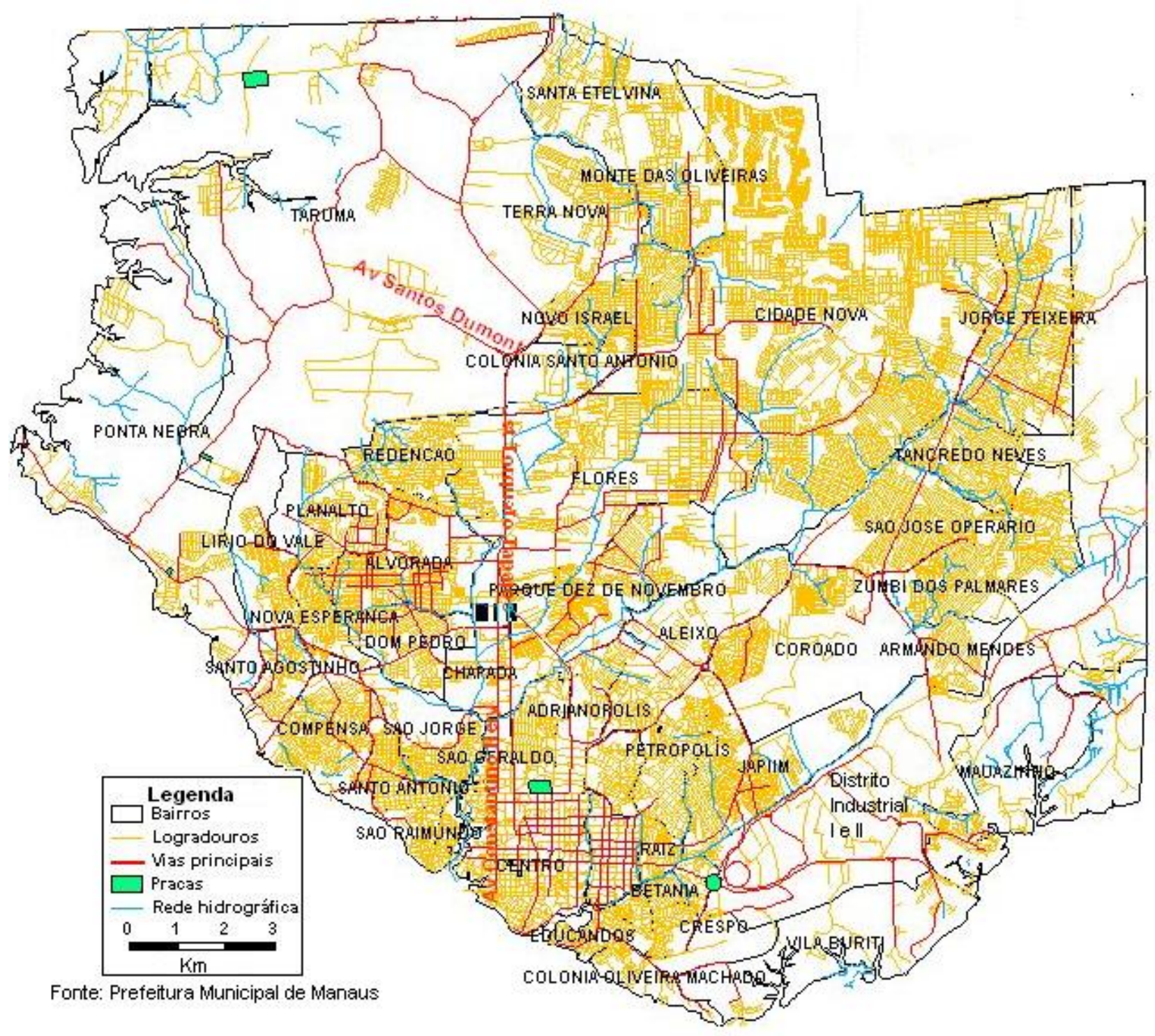

\footnotetext{
${ }^{50}$ Não questionamos aqui se os empreendimentos aprovados apresentam ou não solução de atendimento de estrutura de saneamento, já que estes devem seguir as normas da Lei 6766/79 a qual prevê esta infraestrutura, devendo ser observada pelo órgão licenciador.
} 
Deve-se destacar que há muitos espaços vazios entremeando a rede urbana, não somente em áreas periféricas de Manaus, onde predominam os novos loteamentos e ocupações irregulares, mas também próximo à área central. Estes vazios, entretanto, se tornam mais comuns em bairros mais afastados do centro, como no caso de bairros como Cidade Nova, Parque 10 de novembro, Santa Etelvina e Monte das Oliveiras, mostrando grande descontinuidade de ocupação territorial.

Deve ser observado, que fora os empreendimentos regulares, aprovados pela Prefeitura do Município de Manaus, constam ainda várias aglomerações urbanas irregulares, situadas em porções periféricas do município.

Durante o trabalho de campo efetuado em Manaus pudemos tomar contato com várias situações de precariedade urbana em bairros situados na periferia Leste do município como Armando Mendes, Zumbi dos Palmares, e Tancredo Neves. Nestes bairros têm surgido novas ocupações irregulares, que contribuem para uma implementação nas demandas por serviços de saneamento básico, as quais, no entanto, não têm sido supridas com a devida oferta destes serviços. Estas novas áreas ocupadas também se estendem ao longo de igarapés, implicando em grande contaminação dos mesmos e no aumento do risco de ocorrência de doenças, principalmente entre as famílias que vivem diretamente em contato com estes cursos d’água.

Nos terrenos mais altos foi possível observar inúmeros pontos de processos erosivos e de carreamento de sedimentos às áreas mais baixas, agravando os problemas com enchentes. A ocorrência de enchentes por sua vez, pode ocasionar o contato da água contaminada pela falta de coleta e tratamento de esgotos, ampliando os riscos de disseminação de doenças.

A imagem a seguir procura ilustrar a situação da ocupação urbana na porção Leste do município. 


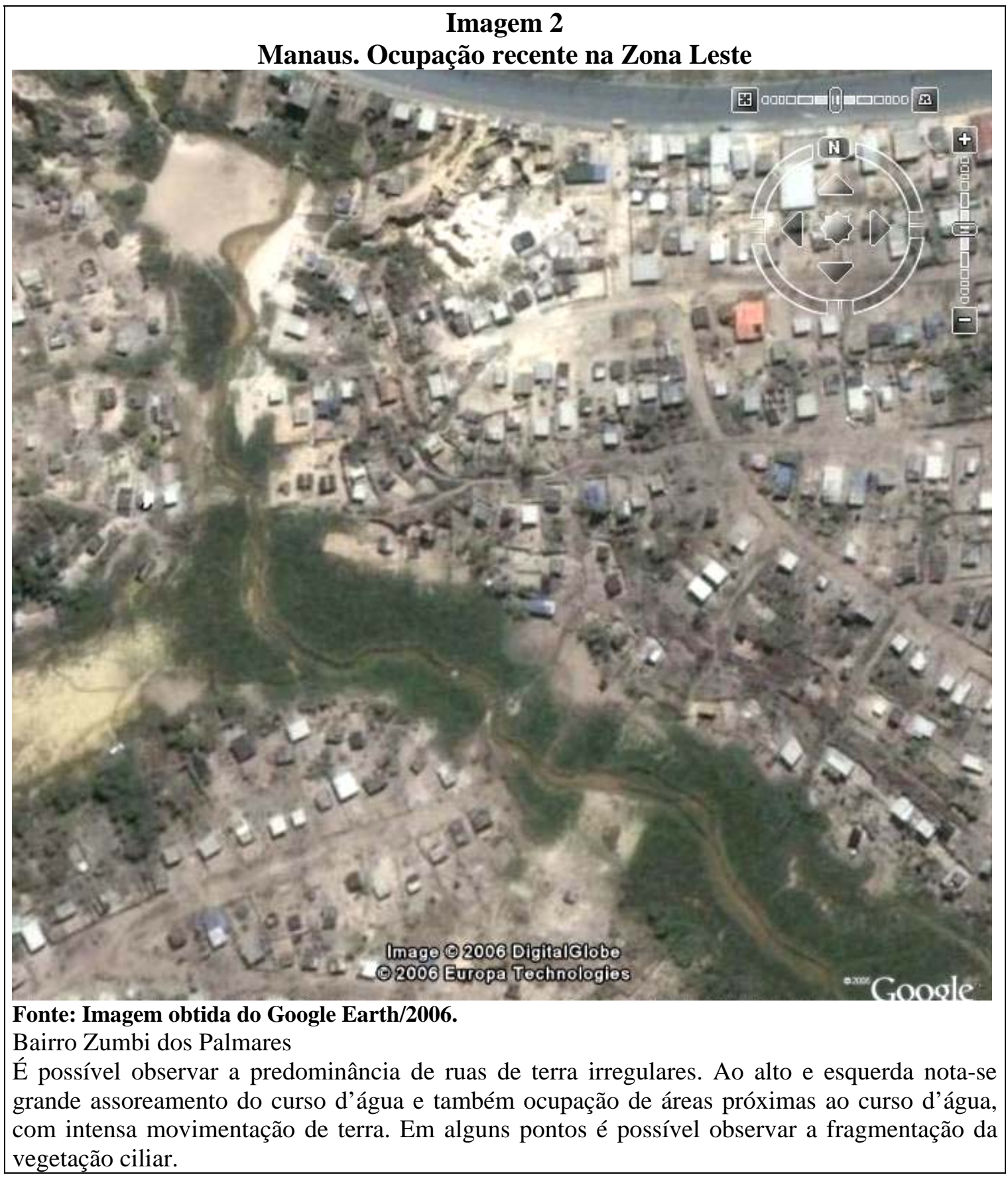


Também na zona Norte e Noroeste do município foi possível observar situação semelhante à da imagem apresentada. Em áreas cuja declividade se apresenta mais acentuada se desenvolvem novas ocupações urbanas, especialmente nos bairros Santa Etelvina, Monte das Oliveiras, Terra Nova e Novo Israel, sendo visível a ausência de serviços públicos como ruas asfaltadas, sistema de águas pluviais e em alguns pontos até de iluminação pública, bem como foi constatada a precariedade na oferta de serviços de saneamento básico.

No extremo Norte o bairro de Tarumã se integra à cidade pela estrada do Tarumã e Avenida Torquarto Tapajós. Em 2004, quando efetuamos o trabalho de campo a ocupação urbana do bairro se resumia a pequenos aglomerados urbanos isolados, ora caracterizados por condomínios horizontais, ora por pequenas comunidades também isoladas de origem indígena. Também foi observado um grande acampamento de trabalhadores rurais, nas imediações da Avenida Torquarto Tapajós.

Em, 2006, foi possível constatar que a área anteriormente ocupada pelo acampamento dos trabalhadores rurais hoje se apresenta como uma nova e extensa ocupação urbana irregular, nos mesmos moldes das ocupações anteriormente citadas.

A imagem a seguir procura ilustrar esta ocupação que caracteriza o rápido crescimento urbano em áreas periféricas da cidade, sem qualquer controle dos órgãos licenciadores, de planejamento e normatizadores do solo urbano.

A base cartográfica foi elaborada pela Prefeitura Municipal de Manaus em 2002 e a imagem de satélite em detalhe, obtida no Google Earth, é de 2006, possibilitando a análise da evolução da ocupação urbana na área apontada em detalhe. 


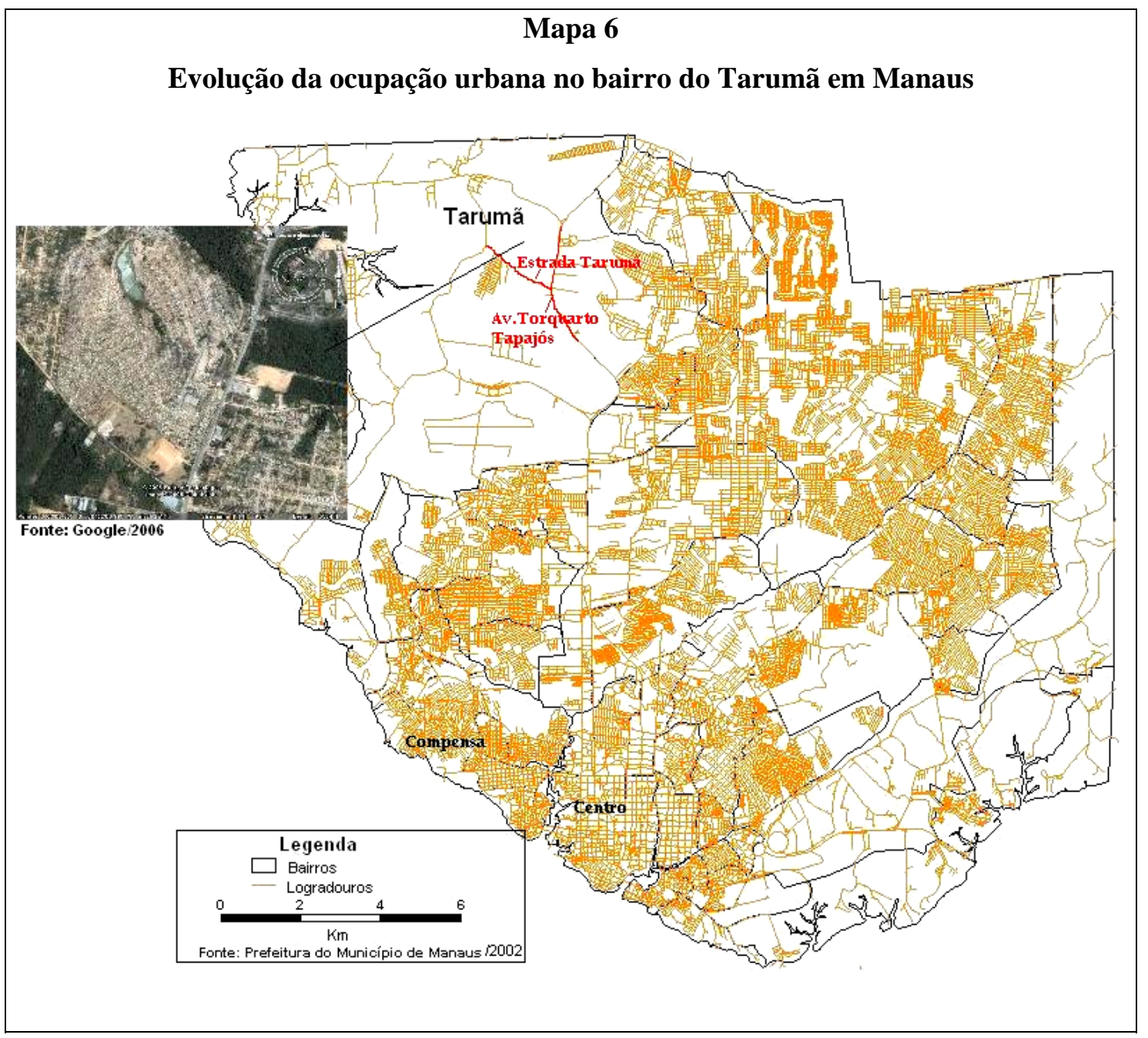

A grande descontinuidade espacial existente, devido aos vazios deixados pelo crescimento urbano desordenado, encarece a extensão das redes de infra-estrutura, e em especial das redes de saneamento básico, já que a principal área de adução se encontra no bairro Compensa, junto ao rio Negro. A partir deste ponto há distribuição de água para os bairros por meio de vários reservatórios instalados em pontos estratégicos, geralmente em terrenos mais altos, para facilitar o bombeamento da água.

Ainda, segundo informações obtidas em campo de representantes da empresa Águas do Amazonas e também, em conversa com a população local, há grande oscilação de energia elétrica nas áreas periféricas de Manaus. Isso implica em dificuldade de bombeamento de água dos reservatórios públicos às residências que se localizam em áreas mais distantes ou em terrenos mais elevados do que os desses reservatórios. Muitas habitações, portanto, recebem água da rede somente por algumas poucas horas por dia e, sua baixa pressão sequer permite a subida da água aos telhados. 
Pudemos observar que alguns moradores que dispõem de caixas d’água as enterram nos quintais das casas para facilitar a entrada de água, devido às falhas de bombeamento. Outros, que se constituem maioria nos bairros mais carentes em infraestrutura, não possuem sequer reservatórios de água, seja devido ao custo dos mesmos ou devido à falta de pressão nas redes que impossibilita a subida da água aos telhados das habitações.

É possível notar que este problema também levanta a questão sobre a falta de articulação entre as políticas públicas que se relacionam ao setor energético e ao setor de saneamento básico.

A foto a seguir, procura ilustrar o bairro que apresenta grande quantidade de habitações sem caixa d’água. Trata-se do bairro Novo Israel, situado na porção Norte da cidade, que também apresenta sérias deficiências em serviços de saneamento básico.

A foto, tirada a partir da residência de um dos entrevistados, atesta que o bairro se caracteriza por terreno irregular, com predomínio de ausência de caixas d’água particulares.

Também é bastante comum a disposição improvisada dos encanamentos que ligam a água da rede às casas, como pode se ver no primeiro plano, na foto. Isto, por vezes, provoca o rompimento destes encanamentos, que consequentemente leva ao aumento do consumo e do custo do abastecimento de água para o morador. 


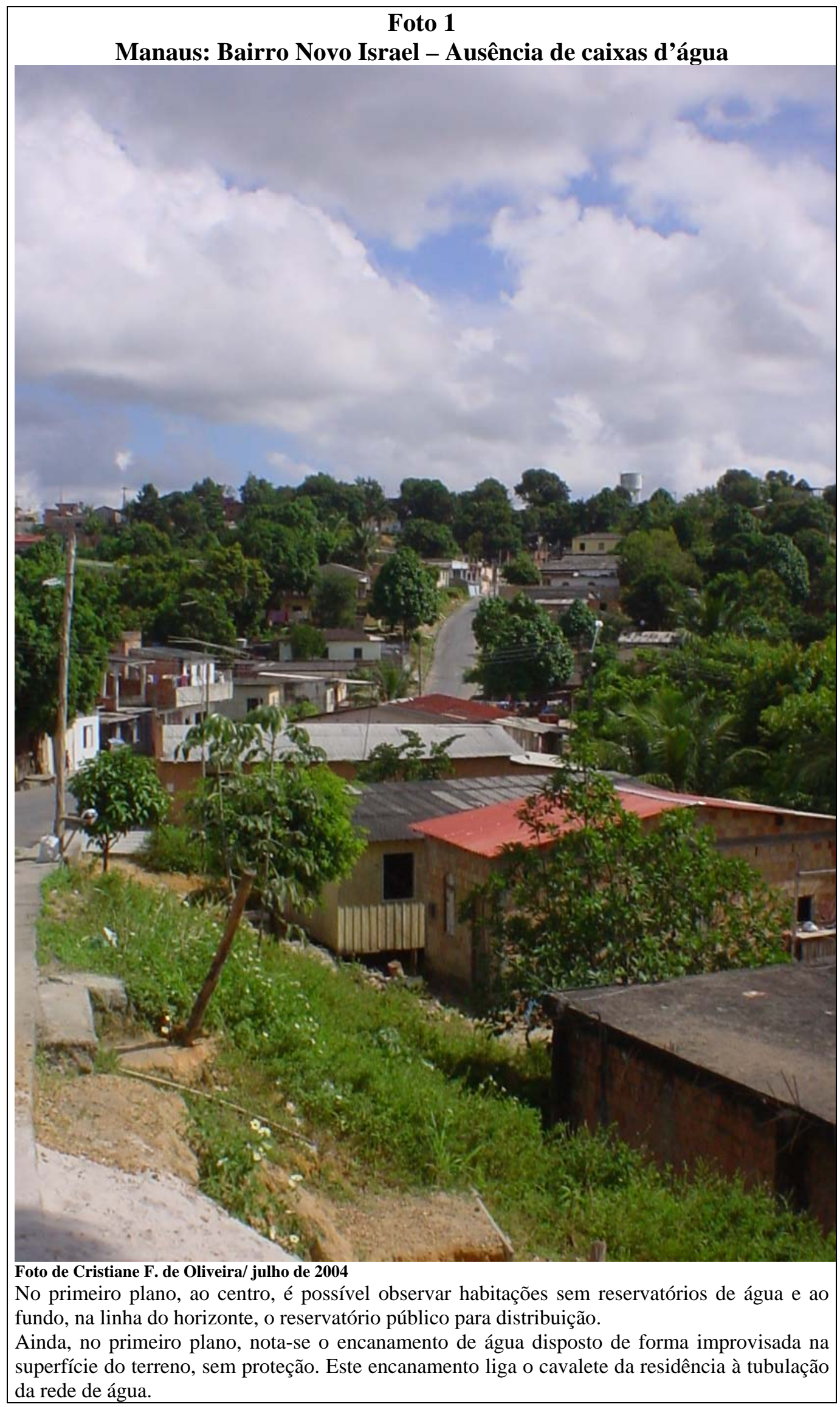


A situação é caótica. Não há alinhamento entre as políticas públicas de energia e de saneamento básico, há crescimento desordenado em vários bairros da cidade, podendo-se citar o caso de Tarumã, na zona Norte, de Zumbi dos Palmares, na zona Leste, entre vários outros. Tudo isto fica agravado pelo fato de que praticamente não há articulação entre as instâncias públicas municipais, responsáveis pelo planejamento urbano e a empresa privada Águas do Amazonas e, também, pelo fato de ter havido um afastamento das decisões de investimentos no setor de saneamento básico por parte das instâncias municipais.

Por parte da iniciativa privada, invariavelmente os problemas relacionados à dificuldade de articulação entre as esferas públicas e a dificuldade de controle do uso do solo urbano por estas esferas, têm sido utilizados como argumento para os parcos investimentos em desenvolvimento da infra-estrutura de saneamento básico.

O bairro do Distrito Industrial I e II, que durante um longo período se expandiu e contribuiu para a geração de empregos atualmente tem seu ritmo refreado. Essa situação se insere num quadro de retração da oferta de emprego formal. Deste modo, as áreas reservadas à expansão do Distrito Industrial têm sido frequentemente invadidas por populações carentes, impulsionando novos adensamentos populacionais em áreas cada vez mais distantes das redes estruturais urbanas, principalmente à Nordeste e extremo Leste.

As ocupações urbanas de áreas mais extremas na porção leste do município originalmente se estruturaram com base na fixação residencial de trabalhadores menos qualificados do Distrito Industrial, como os bairros São José Operário, Zumbi dos Palmares, Armando Mendes, Tancredo Neves e Mauazinho. Porém, atualmente pode-se observar um grande adensamento populacional nestas áreas, extrapolando-se grandemente os núcleos urbanos originais, principalmente no sentido norte. As construções nesta área são muito precárias, refletindo o empobrecimento da população, que tem sofrido com as altas taxas de desemprego, em parte em detrimento da decadência da Zona Franca de Manaus e em parte por falta de uma política de desenvolvimento local, que pudesse suplantar o modelo exógeno reproduzido até então, como observou Becker (2001: p.136).

Está obvio, podemos dizer que para o desenvolvimento de Manaus são necessários investimentos de infra-estrutura refletindo em possibilidades de crescimento endógeno, ou seja, que possibilitem a ampliação do acesso à cidadania por meio da melhoria das condições de saneamento básico, habitação, emprego e educação. 
Em suma, Manaus apresenta um cenário de ocupação urbana e de oferta de serviços de saneamento básico que não tem propiciado condições de acesso, à grande parte de sua população, à cidadania. Também, foi possível constatar a rápida evolução do comprometimento dos recursos hídricos locais, bem como o aumento dos riscos de disseminação de doenças veiculadas por água contaminada. Estes fatos mostram que não somente os serviços de saneamento básico dependem fortemente da existência de políticas públicas urbanas e de saúde, mas vice-versa e, se entre as instâncias públicas esta articulação é difícil, com a atuação da iniciativa privada esta articulação se mostrou inexistente.

\subsection{As políticas de saneamento básico em Limeira}

Limeira que se localiza no interior paulista, distando $154 \mathrm{~km}$ da cidade mais importante do Estado, assume uma posição geográfica estratégica em relação às possibilidades de acesso à cidade de São Paulo e em relação ao acesso a importantes áreas de reserva de água, como a Bacia Hidrográfica do Paraná e ao Aqüífero Guarani.

No que concerne ao acesso à água, Limeira, está situada em área de recarga do Aqüífero Guarani e dista menos de 50 km de Rio Claro, que por sua vez, está incluído nas áreas de afloramento do mesmo Aqüífero.

O potencial de ocorrência de água do Aqüífero Guarani é um dos maiores do mundo com reservatórios subterrâneos que se estendem sob uma área de 1,2 milhões de quilômetros quadrados. Contudo, os volumes de água não se distribuem igualmente em todas as áreas deste sistema, como ressalta Machado (2006). Segundo o mesmo autor o Estado de São Paulo é uma das áreas mais privilegiadas, e dentro dele as áreas de afloramento.

Este grande manancial, porém, não está livre de riscos de contaminação oriundos de fontes diversas, desde uso de agrotóxicos em larga escala, comum nesta área do Estado, devido a moderna produção agrícola voltada para as agroindústrias, até o “simples” despejo de efluentes domésticos e industriais sem o devido tratamento. Desse modo, já se constatou em pesquisa divulgada em artigo da FAPESP (2001), pontos de contaminação por dejetos de suinocultura, mineração de carvão e produtos tóxicos de origem industrial ou agrícola, além de amostras com teores excessivos de elementos radioativos, como o rádio e radônio, estes associados a câncer pulmonar e estomacal.

Fica clara, portanto, a necessidade iminente de controle da qualidade da água e dos despejos de efluentes nos cursos d’água. 
Grande parte da área urbana de Limeira está localizada na sub-Bacia do Ribeirão Tatu pertencente à Bacia do rio Piracicaba. O ribeirão Tatu, principal rio desta subBacia está atualmente retificado e canalizado, entretanto, recebe, ainda sem tratamento, grandes volumes de esgotos coletados da cidade.

O principal manancial que abastece a cidade é o rio Jaguari, afluente do rio Piracicaba, mas também o Ribeirão do Pinhal contribui para uma parte importante do abastecimento.

Em relação à possibilidade de acesso a pontos importantes do Estado de SP, Limeira está integrada ao interior do Estado e à capital por diversas rodovias, entre as quais, a Anhanguera (SP-330), a Washington Luiz (SP-310) e Rodovia Mogi-MirimPiracicaba (SP-134).

O mapa a seguir destaca também a divisão da cidade em bairros e os logradouros que nos auxiliam na apresentação da espacialidade da área urbana.

\section{Mapa 7}

\section{Município de Limeira:Ocupação urbana e bairros}

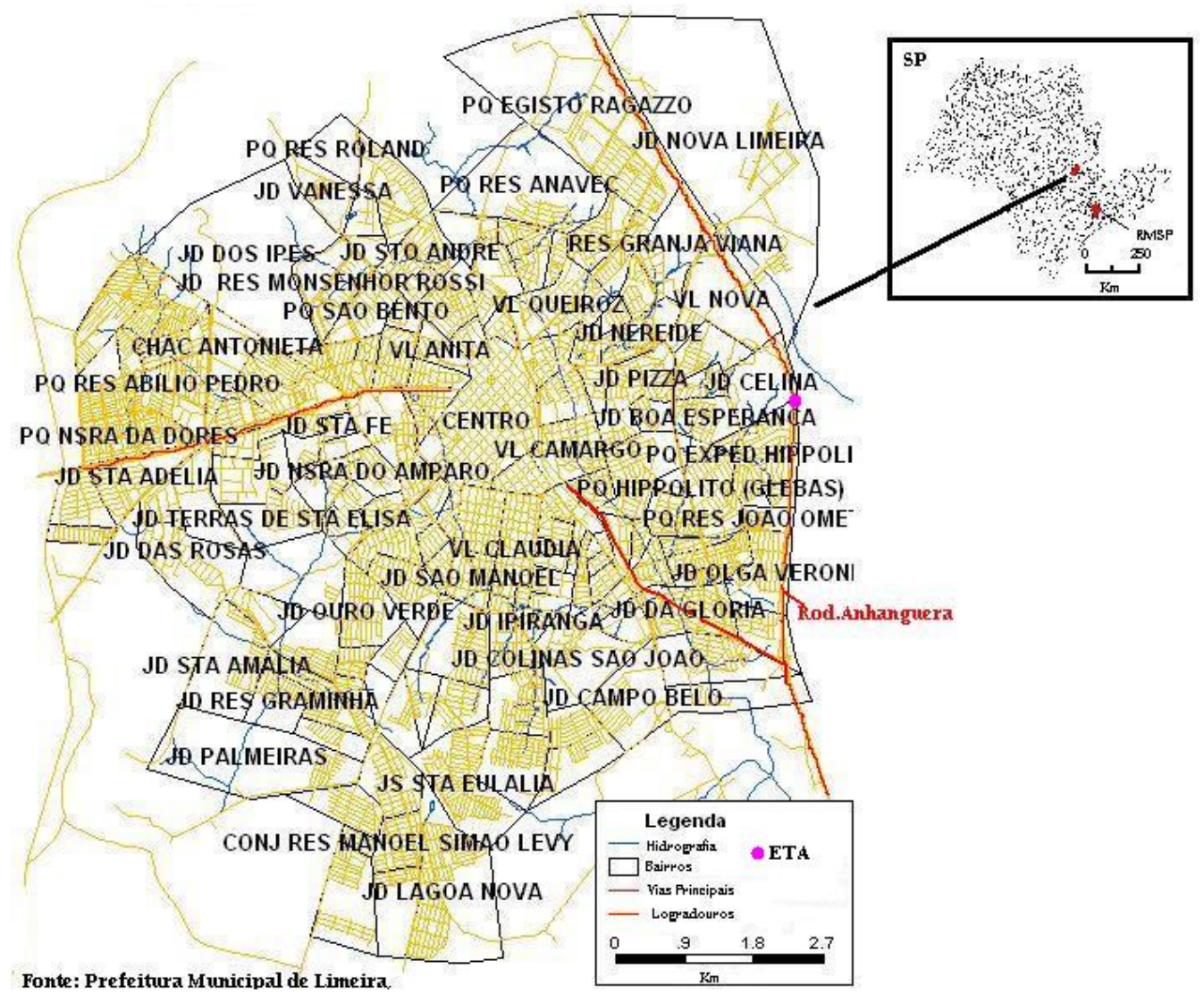

Fonte: Prefeitura Municipal de Limeira 
Segundo a Seade atualmente o município de Limeira conta com uma população de 271.646 habitantes e alto grau de urbanização com 96,45\%. O índice de desenvolvimento humano municipal é de 0,814 o mesmo do que o do Estado de São Paulo, demonstrando boa capacidade de atendimento das demandas por parte das instâncias municipais.

Não se pode deixar de considerar que Limeira está inserida na Região Administrativa de Campinas e que recebeu grandes incentivos fiscais no período de interiorização do desenvolvimento, como ressaltado por Cano (1988). Estes incentivos fomentaram o desenvolvimento industrial de forma que atualmente este município se encontra integrado ao espaço metropolizado, como ressalta Lencioni (2003).

No entanto, como destacado por Lencioni (2003) e por Arroyo (2004) ao mesmo tempo em que a metropolização do espaço se difunde por várias localidades, estas mantém uma relação hierárquica com os centros de decisão; no caso com a cidade de São Paulo.

Por isso é que o grupo Suez S.A. apesar de atuar na operação dos serviços em Limeira possui sede administrativa em São Paulo, onde mantém sua equipe de gestão em contato com os negócios internacionais e articula as políticas de regulação do setor de saneamento básico em direção aos interesses do grupo, como previsto por Arroyo:

É o grupo, e não a firma ou a empresa individual, quem define as mudanças na topologia das empresas, quem define as alianças estratégicas, quem discute e faz lobby frente aos governos. Essa ação é o prelúdio da regulação. A metrópole paulistana, ao albegar a sede de numerosos grupos econômicos, tanto nacionais como estrangeiros, fortalece seu papel na regulação do território. $^{51}$

Atualmente a infra-estrutura urbana de Limeira atende as demandas de grande parte de sua população e, em relação ao setor de saneamento básico, como observado por Justo (2004) este atendimento só foi alcançado, após praticamente 5 anos de concessão dos serviços de saneamento básico à iniciativa privada, graças aos acordos

\footnotetext{
${ }^{51}$ ARROYO, Mônica. São Paulo e os fluxos internacionais de mercadorias. In: CARLOS, A.F.A. e OLIVEIRA, A.U.de. (Orgs.) Geografias de São Paulo. A metrópole do século XXI. São Paulo: Contexto, 2004. p.101.
} 
firmados em 2000 entre a Prefeitura de Limeira e a empresa Águas de Limeira. Lembramos que o acordo incluiu a autorização para a implementação dos aumentos de tarifas que foram repassadas aos usuários em troca da assunção de dívidas do SAAE de Limeira. Estas dívidas, por sua vez, foram contraídas para efetuar investimentos em saneamento básico em anos imediatamente anteriores à concessão.

Estes investimentos por parte do SAAE de Limeira, como lembra Justo (2004), teriam sido possibilitados por meio de um consórcio firmado entre várias indústrias de Limeira que anteciparam os valores que deveriam ser investidos em troca do pagamento posterior viabilizado pelas tarifas futuras a serem arrecadadas. Neste sentido, a prefeitura pôde viabilizar investimentos sem depender dos financiamentos públicos, que por sua vez estavam bloqueados à iniciativa pública como já abordado no segundo capítulo.

Em relação às tarifas aplicadas, nota-se que considerando o desenvolvimento econômico de Limeira e o nível de renda da população a possibilidade de inadimplência não é alta.

Segundo dados da Seade ${ }^{52}$ para o ano de 1998, a renda familiar de municípios do interior, incluindo Limeira apresentava a seguinte distribuição:

Tabela 7

Limeira. Classe de rendimentos em 1998

\begin{tabular}{|c|c||}
\hline \hline $\begin{array}{l}\text { Classe de rendimentos } \\
\text { familiar } \\
\text { mínimos) }\end{array}$ (em salários \\
\hline $0-2$ & \% da população \\
\hline 2 a 3 & 7,2 \\
\hline 3 a 5 & 16,5 \\
\hline 5 a 10 & 29 \\
\hline 10 a 20 & 22,3 \\
\hline Mais de 20 & 13,00 \\
\hline Total & 100,00 \\
\hline
\end{tabular}

Fonte: Seade. Pesquisa de Condiçãod e vida no Estado de São Paulo

A análise desta distribuição de rendimentos nos leva a considerar que, para grande parte da população, as tarifas de água não pesavam fortemente no orçamento

52 Seade. Pesquisa de Condição de vida no Estado de São Paulo. Disponível em < http://www.seade.gov.br/cgi-bin/pcvv98/opcao_pcv_01.ksh?ano=1998 > Acesso em 08/08/2006. 
familiar, já que neste município cerca de $64 \%$ da população possuía rendimentos que ultrapassavam 5 salários mínimos.

No entanto, para os $12 \%$ da população que vivia com até 2 salários mínimos, o aumento das tarifas certamente representou grande peso no orçamento familiar.

Conforme Vargas e Lima (2004, p.92) há um programa de inclusão ao acesso implementado pela empresa Águas de Limeira, com desconto de 50\% na tarifa mínima de água e esgotos para famílias com rendimentos de até dois salários mínimos, que foi proposto a 5\% das famílias. Contudo, ficou de fora deste benefício uma grande parcela da população, já que, que segundo os mesmos autores, as famílias que se enquadravam neste programa conformavam 24\% da população em 2003.

Deste modo, apesar do alto nível de renda de grande parte da população é possível afirmar que o município não é um todo homogêneo, de modo que cerca de 20\% da população corre o risco de exclusão dos serviços face ao peso das tarifas no orçamento familiar.

O grupo Suez S.A. ao obter a concessão dos serviços de Limeira não somente aproveitou a situação favorável de acentuado desenvolvimento econômico e urbano e a baixa potencialidade de inadimplência da população, como também incorporou, como destacado por Justo (2004), parte dos investimentos em saneamento básico efetuados em anos anteriores, pela Prefeitura de Limeira. Segundo o autor, a Prefeitura já vinha investindo em ampliação da capacidade de captação de água, contraindo dívidas que não foram assumidas completamente pela empresa Águas de Limeira, no ato da concessão dos serviços de saneamento básico em 1995.

Em Limeira as políticas de saneamento básico mostraram-se articuladas as demais políticas de desenvolvimento urbano, não tendo sido observado, durante a pesquisa de campo, bairros que apresentassem ocupações irregulares ou situação de precariedade quanto às instalações sanitárias, de distribuição de água e coleta de esgotos, tal como foi possível observar em Manaus.

Com o objetivo de analisarmos mais detalhadamente o desenvolvimento dos serviços de saneamento básico nas duas cidades, procuraremos discorrer sobre os dados divulgados pelo SNIS e sobre as informações obtidas em campo ${ }^{53}$.

Antes disto, porém, devemos esclarecer como foi obtida nossa população amostral para o desenvolvimento do trabalho de campo.

\footnotetext{
${ }^{53}$ A pesquisa de campo foi elaborada em duas etapas, sendo que em Manaus foi realizada em julho de 2004 e em Limeira em setembro de 2005.
} 
O processo de escolha da amostra se iniciou com o levantamento de informações sobre a estrutura de saneamento básico dispostos pelo Sistema IBGE de Recuperação Automática - SIDRA. Neste banco de dados pudemos obter índices de atendimentos de abastecimento de água e de coleta de esgotos por bairros de Manaus e por município em Limeira $^{54}$. Sendo assim, para o caso de Manaus foi possível chegar a um plano de detalhamento maior na seleção das áreas amostradas.

O mapeamento das informações do IBGE para Limeira resultou em um único mapa contendo o valor médio de abastecimento de água no município, que não nos auxiliava na escolha dos pontos de amostragem.

Como já havia sido efetuado um levantamento de informações sistemático sobre qualidade da água em Limeira, por parte de um projeto denominado "Pró-Água”, procuramos nos orientar pelos pontos de coleta de água já efetuados neste projeto.

O projeto denominado "Pró-Água” foi desenvolvido pelo Instituto Adolfo Lutz, com a colaboração da Secretaria Municipal de Vigilância Sanitária de Limeira e teve por objetivo avaliar a qualidade da água em Limeira, com coleta sistemática e análise de amostras de água, a partir de 1997.

Com a permissão da Secretaria Municipal de Vigilância Sanitária de Limeira, pudemos ter acesso aos laudos de análise das coletas de água já efetuadas e procuramos mapear a localização de alguns pontos onde haviam sido coletadas amostras de água, de forma que pudessem ser representativos quanto à cobertura de toda a cidade de Limeira. Deste modo, obtivemos pontos para aplicação de 18 questionários em diversos pontos da cidade, cobrindo a zona central, Leste, Oeste, Norte e Sul.

O questionário foi elaborado com o objetivo de possibilitar um panorama sobre o grau de satisfação da população do município no que diz respeito à estrutura de saneamento básico. O questionário também buscou conhecer mais profundamente no âmbito local os principais problemas decorrentes da estrutura sanitária que têm afetado as populações envolvidas, proporcionando ainda, a possibilidade de avaliação das políticas de economia de água desenvolvidas pela empresa responsável pelos serviços de saneamento básico ou por órgãos públicos.

O mapa a seguir procura ilustrar os pontos escolhidos para aplicação dos questionários em Limeira.

\footnotetext{
54 Conforme o IBGE nem todos os municípios do SIDRA apresentam detalhamento no âmbito de subdistritos e bairros, como Manaus. Em limeira os dados apresentados dizem respeito ao município.
} 


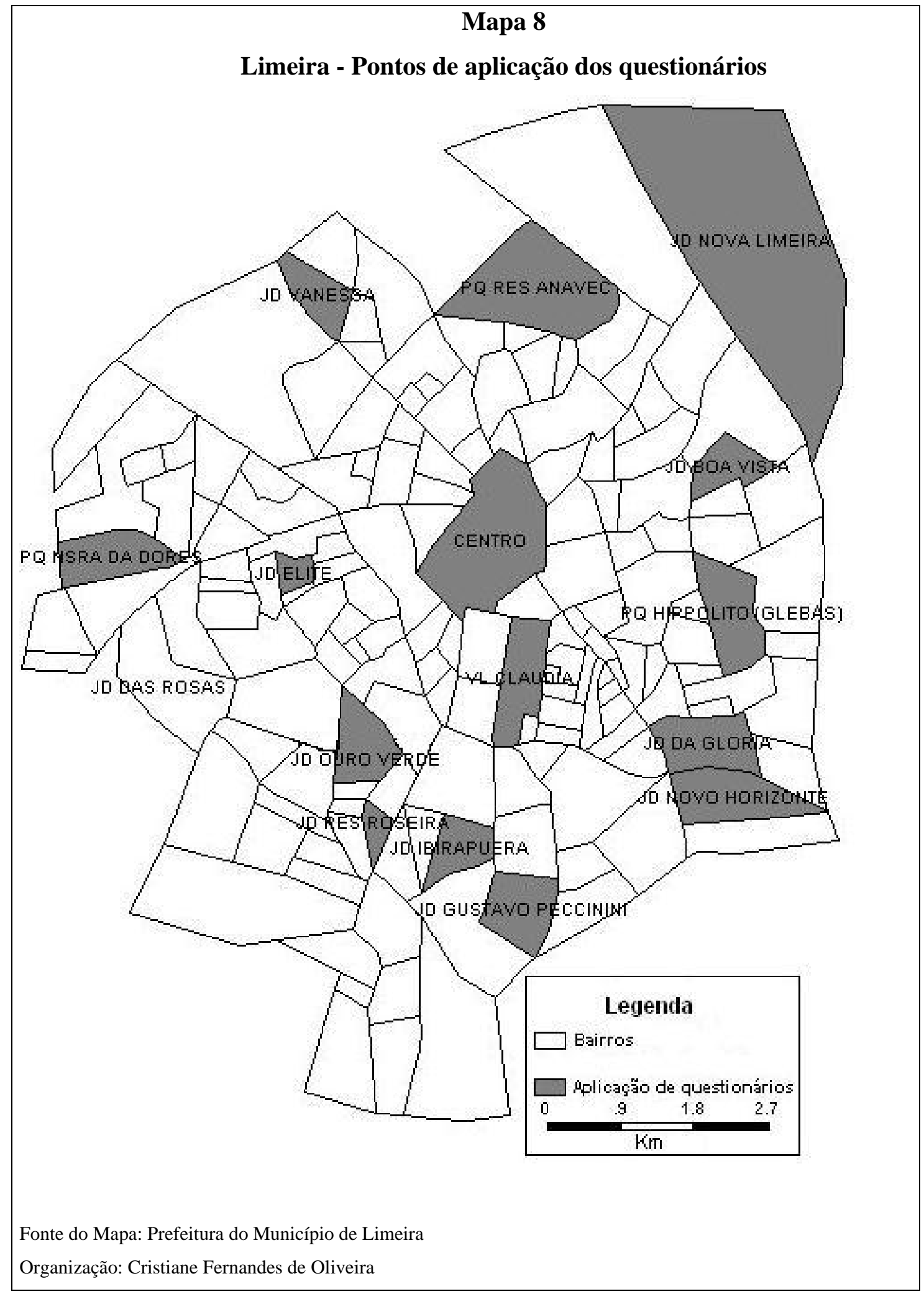


Dois modelos de questionários foram desenvolvidos: um para aplicação em domicílios conectados à rede geral de distribuição de água (sob responsabilidade da empresa privada) e outro para ser aplicado em domicílios não conectados à rede, conforme pode ser apreciado nos anexos deste relatório.

Em Limeira só foram aplicados questionários de domicílios ligados à rede geral, já que o índice de cobertura, divulgado pelo IBGE para esta cidade era alto e as amostras coletadas pela Secretaria Municipal da Vigilância Sanitária haviam sido coletadas de domicílios ligados à rede.

O número de questionários aplicados foi decidido em função do tempo disponível para coleta e análise da qualidade de água em Manaus, na qual o Lacen de Manaus teve um papel fundamental, e para a aplicação dos questionários.

A análise das amostras de água coletada em Manaus foi efetuada pelo Laboratório Central de Saúde Pública - Lacen de Manaus, sendo que alguns laudos exemplificativos sobre as análises das amostras de água coletadas, constam dos anexos deste trabalho ${ }^{55}$.

O Lacen é um órgão público que realiza vários tipos de análise laboratoriais, entre as quais análise de leite materno, análise de água de pontos duvidosos quanto à qualidade ou quanto ao risco de transmissão de doenças, etc.

De acordo com a disponibilidade de tempo do Lacen de Manaus para analisar as amostras de água coletadas em nossa pesquisa é que foi calculado o número total de amostras e de questionários que poderiam ser aplicados dentro do mesmo período. Deste modo, para Manaus, pudemos coletar 18 amostras de água e aplicamos 100 questionários em domicílios ligados à rede de abastecimento de água e 33 para domicílios não ligados à rede de água.

Proporcionalmente, em relação à população de Limeira, aplicamos 18 questionários em locais onde já havia dados sobre a qualidade da água, a partir do projeto Pró-Água.

Em Limeira a espacialização das amostras se deu em função dos laudos das análises de água pré-existentes e no caso de Manaus houve necessidade de efetuarmos uma análise estatística para coletar as amostras e aplicar os questionários em locais representativos.

\footnotetext{
${ }^{55}$ Foram escolhidos como exemplos para Manaus 1 laudo de acordo e um em desacordo com os parâmetros de potabilidade exigidos para água coletada na rede de abastecimento (em cavaletes da entrada das residências) e um laudo analisado de água de poço. Para Limeira apresentamos um laudo sobre a análise da água coletada da rede que representa os demais.
} 
Para esta análise estatística contamos com o apoio da professora Dra. Claudia Monteiro Peixoto do Departamento de Estatística da Faculdade de Matemática da USP, que procurou nos orientar como poderíamos adequar a espacialização das amostras de acordo com um modelo estatístico.

Deste modo, utilizamos como base espacial o mapeamento das médias de abastecimento de água por bairro de Manaus, a partir da base de dados do IBGE.

Este mapeamento nos mostrou que os índices de cobertura de água por rede de abastecimento se dividiam, aproximadamente, em seis diferentes faixas, contadas a partir da principal área de captação de água, no bairro Compensa, junto ao rio Negro. Pudemos visualizar, a partir deste mapeamento, quais áreas possuíam um maior índice de cobertura dos serviços e quais seriam as prováveis "pontas de rede”, onde o atendimento ainda é precário ou inexiste.

Procuramos a partir deste primeiro mapa, estabelecer um critério para esta divisão por faixas. Este critério foi o da distância entre o bairro e a principal área de captação de água, considerando-se também a aproximação quanto ao índice de cobertura de água. Desta forma, obtivemos 6 faixas, na qual a primeira se inicia a partir do ponto de captação (adução) de água no rio Negro, no bairro de Compensa, zona Oeste de Manaus e possui um raio de 9,5km a partir da estação de bombeamento de água, conhecida como Ponta do Ismael. Nesta faixa se concentram os bairros com mais de $90 \%$ de cobertura de serviços.

A segunda faixa se inicia onde termina a primeira, num raio de 9,5 km a partir da estação de bombeamento Ponta de Ismael e se encerra em um raio de 14,5 km a partir deste mesmo ponto de captação, tendo sido acrescentados $5 \mathrm{~km}$ de raio. Os limites das demais faixas foram estabelecidos, também, a partir da somatória de $5 \mathrm{~km}$ de raio, para cada uma.

Os bairros que possuíam a maior parte de sua área urbana em uma determinada faixa foram a esta agregados. Caso a extensão da área urbana do bairro ultrapassasse várias faixas, usamos o critério de menor distância do ponto de adução para agregá-lo a uma determinada faixa. Como exemplo destes critérios o bairro do Tarumã (n.51) foi agregado à faixa 4 devido sua área urbana se localizar em grande parte nesta faixa.

O mapa a seguir ilustra as 6 faixas amostrais com seus devidos bairros já agregados. É interessante notar, por meio do mapeamento das faixas a seguir, que as faixas mais distantes do ponto de captação contemplam os bairros com índices mais baixos de cobertura de água. 


\section{Mapa 9}

Manaus: Faixas de cobertura de abastecimento de água

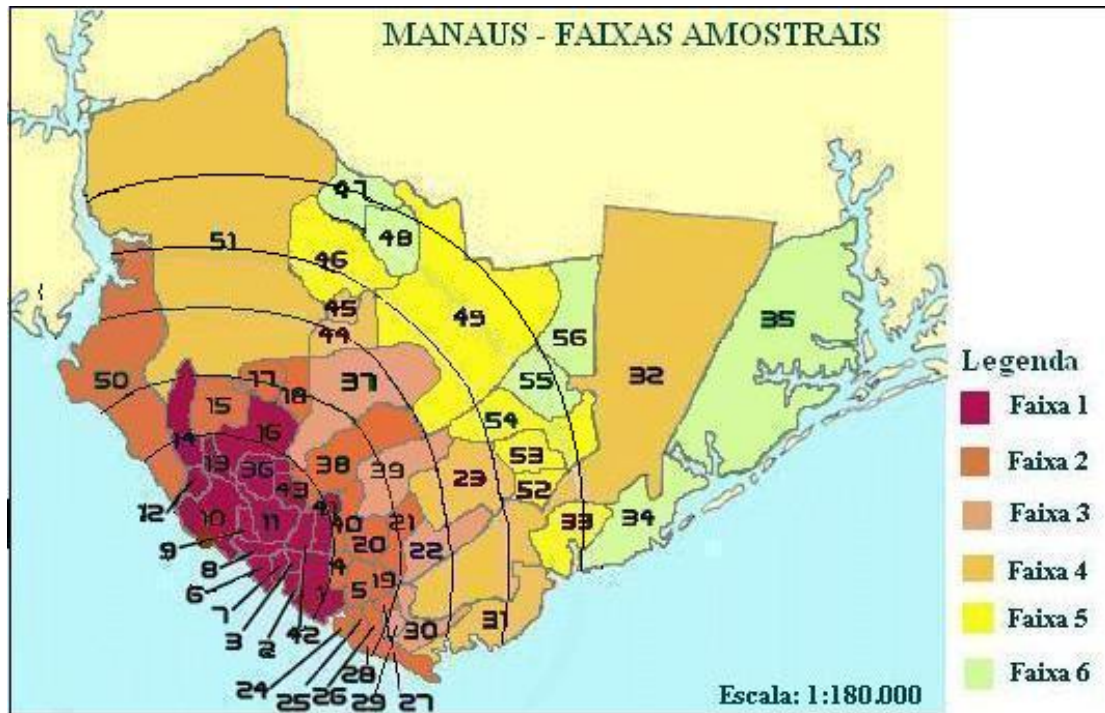

Bairros (Índice de distribuiçấo de água - \%)

1 - centro (94)

2 - Aparecida (92)

3 - Presidente Vargas (97)

6 - Sẫo Raimundo (99)

7 - Glória (98)

8 - Santo Antonio (99)

9 - Vila da Prata (98)

10- Compensa (98)

11 - São Jorge $(96)$

12 - Santo Agostinho (95)

13 - Nova Esperança (91)

14 - Lírio do Vale (97)

16 - Alvorada (95)

41 - N.Senhora das Graças (82)

42 - São Geraldo (92)

43 - Chapada (92)
4- Praça 14 de Janeiro (98)

5 - Cachoeirinha (97)

15 - Planalto (95)

17- Redençẫo (86)

18 - Da Paz (86)

19 - Raiz (95)

20 - Sấo Francisco (92)

21 - Petrópolis (95)

24 - Educandos (98)

25 - Santa Luzia (98)

26 - Morro da Liberdade (99)

27 - Betânia (98)

28 - Colônia Oliveira Machado (97)

38 - Parque 10 de Novembro (74)

40 - Adrianópolis (64)

22- Japiirn (95)
29 - Sấo Lázaro (86)
30 - Crespo (97)
37 - Flores (27)
39 - Aleixo (80)

23 - Coroado (80)
31 - Vila Buriti (69)
32 - Vila Industrial (44)
44 - Colônia Santo Antonio (36)
45 - Novo Israel (57)
51 - Tarumẫ (1)

33- Mauazinho (90)

46 - Colônia Terra Nova (38)

49 - Cidade Nova (61)

52 - Armando Mendes (89)

53 - Zumbi dos Palmares (88)

54 - Sẫo José Operário (61)

34 - Colônia Antonio Aleixo (91)

35 - Puraquequara (51)

47 - Santa Etelvina (62)

48 - Monte das Oliveiras (1)

55 - Tancredo Neves $(60)$

56 - Jorge Teixeira (27)

Após o mapeamento com o estabelecimento das faixas, pudemos agregar os bairros pertencentes à mesma faixa e obter a média de cobertura dos serviços por faixas, conforme mostra a tabela a seguir. 
Tabela 8

Manaus - Bairros agrupados por faixa de proximidade da área de captação e cobertura de abastecimento de água

\begin{tabular}{|c|c|}
\hline Bairros & $\begin{array}{l}\text { \% de domicílios } \\
\text { conectados à rede }\end{array}$ \\
\hline \multicolumn{2}{|c|}{$\begin{array}{c}\text { Faixa } 1 \text { Média }=\begin{array}{c}94,8 \% \text { domicílios conectados à } \\
\text { rede }\end{array} \\
\text { red }\end{array}$} \\
\hline Lírio do Vale & 97 \\
\hline Nova Esperança & 91 \\
\hline Santo Agostinho & 95 \\
\hline Compensa & 98 \\
\hline Alvorada & 95 \\
\hline Dom Pedro & 98 \\
\hline Chapada & 92 \\
\hline São Jorge & 96 \\
\hline São Geraldo & 92 \\
\hline Nossa S ${ }^{a}$ das Graças & 82 \\
\hline Vila da Prata & 98 \\
\hline Santo Antonio & 99 \\
\hline São Raimundo & 99 \\
\hline Glória & 98 \\
\hline Presidente Vargas & 97 \\
\hline Aparecida & 92 \\
\hline Centro & 94 \\
\hline \multicolumn{2}{|c|}{ Faixa 2 Média = 89\% domicílios conectados à red } \\
\hline Ponta Negra & 61 \\
\hline Planalto & 95 \\
\hline Redenção & 86 \\
\hline Da Paz & 86 \\
\hline Parque 10 de Novembro & 74 \\
\hline Adrianópolis & 64 \\
\hline Praça 14 de Janeiro & 98 \\
\hline São Francisco & 92 \\
\hline Cachoeirinha & 97 \\
\hline Raiz & 95 \\
\hline Educandos & 98 \\
\hline Santa Luzia & 98 \\
\hline Morro da Liberdade & 99 \\
\hline Betânia & 98 \\
\hline Colônia Oliveira Machado & 97 \\
\hline Petrópolis & 95 \\
\hline \multicolumn{2}{|c|}{ Faixa 3 Média $=77 \%$ domicílios conectados à rede } \\
\hline Crespo & 97 \\
\hline São Lázaro & 86 \\
\hline Japiim & 95 \\
\hline Aleixo & 80 \\
\hline Flores & 27 \\
\hline
\end{tabular}




\begin{tabular}{|c|c|}
\hline \multicolumn{2}{|c|}{$\begin{array}{l}\text { Faixa } 4 \text { Média }=48,1 \% \text { domicílios conectados } \\
\text { rede }\end{array}$} \\
\hline Vila Buriti & 69 \\
\hline Distrito Industrial[ & 44 \\
\hline Coroado & 80 \\
\hline Colônia Santo Antonio & 38 \\
\hline Novo Israel & 57 \\
\hline Tarumã & 1 \\
\hline \multicolumn{2}{|c|}{ Faixa 5 Média = 71\% domicílios conectados à rede } \\
\hline Colônia Terra Nova & 38 \\
\hline Cidade Nova & 61 \\
\hline São José Operário & 61 \\
\hline Zumbi dos Palmares & 88 \\
\hline Armando Mendes & 89 \\
\hline Mauazinho & 90 \\
\hline \multicolumn{2}{|c|}{ Faixa 6 Média $=40 \%$ domicílios conectados à rede } \\
\hline Tancredo Neves & 60 \\
\hline Jorge Teixeira & 27 \\
\hline Puraquequara & 51 \\
\hline Monte das Oliveiras & 1 \\
\hline Santa Etelvina & 62 \\
\hline Colônia Antonio Aleixo & 91 \\
\hline
\end{tabular}

Fonte: IBGE/2000 - Organização: Cristiane F.de Oliveira

Para Manaus a definição da localização onde seriam coletadas as amostras e aplicados os questionários se fundou em critério estatístico espacial, que envolveu as faixas de distribuição de atendimento dos serviços de água e esgoto.

Deste modo, dividindo o total de amostras (18) pelo número de faixas existentes (6), obtivemos o peso 3. Este peso foi utilizado para multiplicação por um fator de ponderação, fator este, determinado pela relação entre a média de abastecimento de água do município de Manaus e a média de abastecimento de água de cada uma das 6 faixas consideradas.

Deste modo, o fator de ponderação é obtido através da divisão da porcentagem média da faixa pela porcentagem média do município de Manaus. A porcentagem média de cobertura de abastecimento segundo o IBGE em Manaus é 75\%, portanto, como resultado obtivemos para cada faixa os seguintes fatores de ponderação:

- Faixa $1=1,2$

- Faixa $2=1,2$ 
- Faixa $3=1,0$

- Faixa $4=0,6$

- Faixa $5=0,5$

- Faixa $6=0,6$

Multiplicando-se o fator de ponderação em cada faixa por 3 obtivemos a quantidade de amostras a serem coletadas por faixa:

- Faixa $1=4$

- Faixa $4=2$

- Faixa $2=4$

- Faixa $5=2$

- Faixa $3=4$

- Faixa $6=2$

O sorteio feito através do aplicativo excel do windows, indicou os seguintes bairros para a coleta de amostras de água:

\begin{tabular}{cl} 
Faixas de bairros & \multicolumn{1}{c}{ Bairros sorteados } \\
1 & \\
& Santo Antonio, Nova Esperança, Pres.Vargas, \\
2 & S.Geraldo \\
3 & Colônia O. Machado, Betânea, Raiz, Planalto \\
4 & Crespo, Aleixo, Flores, Japiim \\
5 & Colônia Santo Antonio(2) \\
6 & Cidade Nova, Armando Mendes, \\
\hline
\end{tabular}

Objetivando selecionar os locais onde seriam aplicados os questionários, aplicamos a mesma lógica estatística utilizada para a escolha das áreas onde seriam coletadas amostras de água.

A quantidade de questionários foi decidida, como já justificado, em razão da disponibilidade de tempo do Lacen de Manaus em nos auxiliar com as análises de água. Em função desta disponibilidade, o trabalho estava previsto para durar dez dias, sendo que seria possível aplicar a princípio cerca de 130 questionários no total.

Procuramos respeitar a proporção existente entre a percentagem de domicílios ligados à rede de água (75\%) e a percentagem para os não ligados (25\%), resultando em nossa pesquisa em um total de 100 questionários aplicáveis aos domicílios ligados à rede e 33 questionários aplicáveis para os domicílios não ligados à rede de água.

Deste modo chegamos a dois pesos, conforme a seguir:

- Peso para os domicílios ligados à rede geral de água = 16 
- Peso para os domicílios não ligados à rede geral de água = 5,5

Como mostra a tabela a seguir os resultados deste procedimento apontaram para cada faixa as seguintes quantidades de questionários que devem ser aplicados por faixa.

\section{Tabela 9}

\section{Manaus - Quantidade de questionários aplicados por faixa de bairros}

\begin{tabular}{|c|c|c|}
\hline Faixas & Domicílios ligados à rede & $\begin{array}{c}\text { Domicílios não ligados à } \\
\text { rede }\end{array}$ \\
\hline 1 & 22 & 7 \\
\hline 2 & 21 & 7 \\
\hline 3 & 18 & 6 \\
\hline 4 & 12 & 5 \\
\hline 5 & 17 & 5 \\
\hline 6 & 10 & 3 \\
\hline
\end{tabular}

Obtidas as quantidades de questionários a serem aplicados em cada uma das faixas compostas por bairros do município de Manaus, utilizamos um recurso do aplicativo Excel da Microsoft para efetuar os sorteios dos bairros por faixas onde se deveriam aplicar os questionários.

Com o objetivo de contemplar maiores detalhes sobre as áreas onde foi efetuada coleta de água, foi aplicado um questionário para cada uma destas áreas. Deste modo, ao sortearmos os bairros em que deveriam ser aplicados questionários, procuramos já incluir os locais em que já haviam sido sorteados para as coletas de água.

Como exemplo disto pode-se citar o caso da faixa 1, na qual deveriam ser aplicados 22 questionários. Porém, como haviam 4 bairros previamente selecionados nesta faixa (das amostras de água), restaram 18 bairros a serem sorteados.

O aplicativo do Excel nos possibilita utilizar a seguinte fórmula para gerar um número real aleatório entre a e b: ALEATÓRIO( )*(b-a)+a, onde a é igual a 1 e b é igual ao total de bairros em cada faixa a ser sorteada. Deve-se então, aplicar a mesma fórmula quantas vezes forem necessárias.

No caso da faixa 1 tínhamos 17 elementos (bairros), e deveríamos obter 18 amostras, portanto a fórmula ALEATÓRIO()*(17-1)+1 foi usada 18 vezes. O resultado apontou o número correspondente ao bairro que deveria ser amostrado, podendo ocorrer o mesmo bairro mais de uma vez ou nenhuma vez. 
De acordo com estes sorteios pudemos definir quais bairros seriam amostrados e qual a quantidade de amostras por bairro seriam efetuadas para a aplicação dos questionários e para a coleta de água, dentro do número total previsto.

Tabela 10. Manaus - Amostras coletadas por bairro

\begin{tabular}{|c|c|c|c|c|}
\hline Bairros & $\begin{array}{c}\% \text { de } \\
\text { domic.conect } \\
\text { à rede }\end{array}$ & $\begin{array}{l}\text { Quest. } \\
\text { Lig. à } \\
\text { rede }\end{array}$ & $\begin{array}{l}\text { Quest. } \\
\text { não lig. à } \\
\text { rede }\end{array}$ & $\begin{array}{l}\text { Amostras } \\
\text { de água }\end{array}$ \\
\hline \multicolumn{5}{|c|}{ Faixa 1 Média = 94,8\% domicílios conectados à rede } \\
\hline Lírio do Vale & 97 & 2 & 0 & \\
\hline Nova Esperança & 91 & 1 & 0 & 1 \\
\hline Santo Agostinho & 95 & 0 & 2 & \\
\hline Compensa & 98 & 2 & 0 & \\
\hline Alvorada & 95 & 1 & 2 & \\
\hline Dom Pedro & 98 & 1 & 1 & \\
\hline Chapada & 92 & 3 & 0 & \\
\hline São Jorge & 96 & 0 & 0 & \\
\hline São Geraldo & 92 & 1 & 0 & 1 \\
\hline Nossa Senhora das Graças & 82 & 1 & 0 & \\
\hline Vila da Prata & 98 & 1 & 0 & \\
\hline Santo Antonio & 99 & 2 & 0 & 1 \\
\hline São Raimundo & 99 & 0 & 0 & \\
\hline Glória & 98 & 2 & 0 & \\
\hline Presidente Vargas & 97 & 2 & 1 & 1 \\
\hline Aparecida & 92 & 2 & 1 & \\
\hline Centro & 94 & 1 & 0 & \\
\hline \multicolumn{5}{|c|}{ Faixa 2 Média = 89\% domicílios conectados à rede } \\
\hline Ponta Negra & 61 & 1 & 1 & \\
\hline Planalto & 95 & 1 & 1 & 1 \\
\hline Redenção & 86 & 2 & 1 & \\
\hline Da Paz & 86 & 1 & 0 & \\
\hline Parque 10 de Novembro & 74 & 1 & 1 & \\
\hline Adrianópolis & 64 & 2 & 0 & \\
\hline Praça 14 de Janeiro & 98 & 0 & 0 & \\
\hline São Francisco & 92 & 2 & 1 & \\
\hline Cachoeirinha & 97 & 1 & 0 & \\
\hline Raiz & 95 & 1 & 0 & 1 \\
\hline Educandos & 98 & 1 & 1 & \\
\hline Santa Luzia & 98 & 3 & 0 & \\
\hline Morro da Liberdade & 99 & 1 & 0 & \\
\hline Betânia & 98 & 2 & 0 & 1 \\
\hline Colônia Oliveira Machado & 97 & 1 & 0 & 1 \\
\hline Petrópolis & 95 & 1 & 1 & \\
\hline \multicolumn{5}{|c|}{ Faixa 3 Média = 77\% domicílios conectados à rede } \\
\hline Crespo & 97 & 2 & 0 & 1 \\
\hline São Lázaro & 86 & 4 & 1 & \\
\hline Japiim & 95 & 6 & 2 & 1 \\
\hline Aleixo & 80 & 4 & 1 & 1 \\
\hline Flores & 27 & 2 & 2 & 1 \\
\hline
\end{tabular}




\begin{tabular}{|c|c|c|c|c|}
\hline \multicolumn{5}{|c|}{ Faixa 4 Média = 48,1\% domicílios conectados à rede } \\
\hline Vila Buriti & 69 & 2 & 0 & \\
\hline Distrito Industrial[ & 44 & 1 & 0 & \\
\hline Coroado & 80 & 2 & 1 & \\
\hline Colônia Santo Antonio & 38 & 3 & 2 & 1 \\
\hline Novo Israel & 57 & 2 & 1 & \\
\hline Tarumã & 1 & 2 & 1 & \\
\hline \multicolumn{5}{|c|}{ Faixa 5 Média = 71\% domicílios conectados à rede } \\
\hline Colônia Terra Nova & 38 & 5 & 1 & \\
\hline Cidade Nova & 61 & 4 & 4 & 1 \\
\hline São José Operário & 61 & 2 & 0 & \\
\hline Zumbi dos Palmares & 88 & 1 & 0 & \\
\hline Armando Mendes & 89 & 3 & 0 & 2 \\
\hline Mauazinho & 90 & 2 & 0 & \\
\hline \multicolumn{5}{|c|}{ Faixa 6 Média = 40\% domicílios conectados à rede } \\
\hline Tancredo Neves & 60 & 2 & 0 & \\
\hline Jorge Teixeira & 27 & 2 & 1 & \\
\hline Puraquequara & 51 & 0 & 0 & \\
\hline Monte das Oliveiras & 1 & 1 & 1 & 1 \\
\hline Santa Etelvina & 62 & 5 & 1 & 1 \\
\hline Totais: & & 100 & 33 & 18 \\
\hline
\end{tabular}

Após os sorteios pudemos constatar que praticamente todos os bairros de Manaus foram contemplados, o que garantiu a representatividade do universo amostral e maior abrangência das informações. 


\section{Os serviços de saneamento básico em Manaus e Limeira: Avanços e Retrocessos}

As informações sobre cobertura de água, publicadas pelo IBGE, além de ter possibilitado a escolha dos pontos onde foram aplicados questionários e coletadas amostras de água, que buscam complementar as informações sobre os serviços de saneamento básico em cada uma das cidades envolvidas, também propicia um panorama sobre as diferenças regionais de desenvolvimento do setor no Brasil.

A tabela a seguir mostra os índices de cobertura de água e esgotos apresentados pelo IBGE em 2000 para os municípios de Limeira e Manaus.

Tabela 11

Limeira e Manaus. Índices de cobertura de saneamento básico em 2000 (\%)

\begin{tabular}{||c|c|c||}
\hline Municípios & Cobertura de água & Cobertura de Esgoto \\
\hline Limeira - SP & 94,85 & 93,77 \\
\hline Manaus - AM & 74,78 & 33,39 \\
\hline
\end{tabular}

Fonte: SIDRA/IBGE/2000

Estas informações mostram a diferença de desenvolvimento do setor de saneamento básico nos dois municípios, que reflete por sua vez, as diferenças regionais quanto aos investimentos no setor.

Também, como pode ser observado na tabela a seguir, há grandes diferenças regionais quanto ao tratamento de água.

\section{Tabela 12}

Regiões do Brasil - Evolução da água distribuída sem tratamento (\%)

\begin{tabular}{||l|c|c||}
\hline Regiões & $\mathbf{1 9 8 9}$ & $\mathbf{2 0 0 0}$ \\
\hline Norte & 14,3 & 32,4 \\
\hline Nordeste & 6,0 & 6,4 \\
\hline Sudeste & 2,6 & 5,6 \\
\hline Sul & 2,1 & 5,9 \\
\hline Centro Oeste & 3,8 & 3,6 \\
\hline
\end{tabular}

Fonte: IBGE - Pesquisa Nacional de Saneamento Básico/2000 
Comparativamente os dados mostravam para o ano 2000 um crescimento muito maior em relação ao volume de água distribuída sem tratamento em relação ao volume tratado, sobretudo na região Norte do país.

Esta situação indica que houve uma preocupação com a distribuição em detrimento do tratamento da água, especialmente no caso da região Norte do país, o que denota o abandono da região no aspecto da qualidade dos serviços de saneamento básico.

No que concerne às diferenças regionais quanto ao desenvolvimento do setor, a Pesquisa Nacional de Saneamento Básico, efetuada pelo IBGE, nos mostra que no Brasil, apesar do crescimento do atendimento da demanda em relação às redes de abastecimento de água, ainda há muito a se fazer, especialmente quanto à qualidade da água servida.

Por sua vez, os esforços promovidos pela empresa Águas do Amazonas no que concerne ao tratamento da água, não estavam relacionados somente à busca do alcance de uma melhoria na qualidade da água, mas principalmente se voltavam à melhoria da imagem da empresa por meio da imagem da água.

Utilizamos o termo “imagem da água”, devido ao fato de que a água distribuída no período anterior à concessão, quando os serviços eram prestados pela Companhia de Saneamento do Amazonas - Cosama, possuía coloração escura, destoando dos parâmetros indicados para potabilidade, muito embora esta coloração não fosse prejudicial à saúde.

De acordo com Di Bernardo e Dantas (2005) a coloração escura da água se deve a presença de matéria orgânica natural dissolvida que por sua vez, pode interferir na qualidade da água tratada em função das reações químicas possíveis.

Como a água do rio Negro é composta por grande quantidade de matéria orgânica dissolvida e somente recentemente foram desenvolvidos processos mais modernos e eficazes para obter a almejada descoloração, durante muitos anos a Cosama foi apelidada pela população de “colama”, por oferecer água com coloração escura.

A água distribuída neste período em geral não era bem aceita para consumo direto e consequentemente a imagem da empresa perante os consumidores não era boa.

No entanto, de acordo com o engenheiro representante da empresa Águas do Amazonas, que nos atendeu em Manaus, a coloração da água não representava necessariamente um problema para a saúde do consumidor, visto que historicamente muitas comunidades ribeirinhas consumiam a água in natura, sem problemas. 
Mesmo assim, logo no início da obtenção da concessão, a empresa Águas do Amazonas realizou uma pesquisa de opinião entre a população de Manaus e constatou que a imagem da empresa poderia melhorar com o avanço no tratamento da água, do ponto de vista de sua coloração. Deste modo, foram feitos investimentos no sentido de, não somente de alcançar os padrões de potabilidade exigidos, mas principalmente de melhorar a aceitação da água e consequentemente, melhorar a imagem da empresa perante os consumidores.

Apesar disso, grande parte da população que é abastecida de água por meio de redes continua não consumindo a água diretamente das torneiras. Em parte, isto se deve a intermitência do abastecimento, que contribui para a queda na qualidade da água, já que a pressão da rede nos momentos de retorno de abastecimento, após um período de racionamento, pode ocasionar a suspensão de partículas que estavam depositadas no fundo das tubulações e reservatórios, causando turbidez da água e a sua rejeição para consumo direto.

Finalmente, o comércio de água “potável” e a disponibilidade de água de poços, por meio de bicas públicas, dispostas em vários pontos da cidade, também têm contribuído para a perpetuação do consumo direto por meio dessas outras fontes, bem como para a minimização dos déficits de cobertura de água em rede, reduzindo as possíveis tensões sociais relacionadas a este problema.

Grande parte dos poços rasos, denominados “cacimba” ou “caipira” efetuados em Manaus com o objetivo de suprimento de água estão contaminados por esgotos sem tratamento. Estes esgotos percolam as camadas superficiais dos solos facilmente, já que em grande parte estes são constituídos de material arenoso, até alcançarem os lençóis de água superficiais que alimentam os poços, contaminando-os.

O consumo de água de poços por sua vez, tem sido a origem da propagação de doenças veiculadas pela água, como a cólera, as gastrenterites e a amebíase, entre outras.

Segundo Silva (2001) em Manaus os poços tubulares, também denominados “artesianos” ou “semi-artesianos” aproveitam a grande ocorrência de água dos Sistemas de Aqüíferos Arenito Alter do Chão e Barreiras, existentes na Bacia Sedimentar do Amazonas. São inúmeros os poços tubulares perfurados, sendo comum, conforme o autor, a falta de controle, de monitoramento ou proteção sanitária, resultando em contaminação dos mesmos. 
Ainda, de acordo com matéria divulgada pela Agência Câmara, em 2005 havia grande preocupação com os “altos índices de mortalidade infantil e de câncer entre moradores do bairro de Novo Israel em Manaus" ${ }^{56}$ devido o consumo de água contaminada de poços. O bairro de Novo Israel está inserido na faixa 4 de nossa pesquisa de campo, situando-se na porção Norte da cidade, onde os déficits de abastecimento por rede são altos.

Enquanto em Manaus uma parte da população consome água dos poços e bicas como opção ou, por desconfiança da qualidade da água oferecida em rede, outra parte a consome como única alternativa ao acesso à água. Em geral é esta parcela da população a mais vulnerável aos problemas de saúde por ser também a população mais pobre da cidade.

Deste modo procuraremos a seguir iniciar a análise da evolução dos serviços de saneamento básico pela questão da coleta e do tratamento de esgotos.

A coleta de esgoto e seu tratamento, durante muitos anos foi relegada à segundo plano, mesmo dentro de políticas de desenvolvimento do setor de saneamento básico. Isto resultou não só no acúmulo dos déficits, que tornam praticamente inviáveis, do ponto de vista financeiro, os investimentos necessários, mas também no aumento do custo de tratamento de água e em grande ônus para a saúde pública. É neste sentido que procuramos tomar a discussão da questão da coleta e do tratamento dos esgotos como ponto de partida para compreendermos a situação do saneamento básico nos dois municípios envolvidos.

\subsection{A coleta e o tratamento de esgotos}

Em 2000, no momento da concessão dos serviços de saneamento básico à iniciativa privada, em Manaus, foi firmado um contrato de concessão entre o governo do Estado do Amazonas e os representantes do grupo Suez, que viriam a ser denominados de “concessionária”, por meio da atuação da empresa criada para prestação dos serviços, a Águas do Amazonas.

De acordo com as metas previstas pelo contrato de concessão, dispostas no Anexo 1, em 2006 os índices de coleta de esgotos em Manaus deveriam atingir 31\% do esgoto produzido. Contudo, é intrigante o fato de que, segundo o IBGE, em Manaus o índice de cobertura de esgotos já atingira 33\% em 2000. Isto demonstra que o contrato

\footnotetext{
${ }^{56}$ Agência Câmara. Audiência vai discutir contaminação de poços artesianos. 22/09/2005. Disponível em: $<$ http://www.camara.gov.br/internet/agencia/materias.asp?pk=75296 > Acesso em 10/10/2005.
} 
foi efetuado de forma a beneficiar e proteger a concessionária, que poderia poupar os investimentos necessários em coleta de esgotos até a próxima etapa a ser cobrada, em 2011, tendo em vista que o índice previsto já era realidade.

Por sua vez, no que concerne a evolução da coleta de esgoto os dados do SNIS para o município de Manaus mostram a seguinte situação, exposta no gráfico a seguir.

\section{Gráfico 16}

\section{Manaus. Evolução do Índice de coleta e de tratamento de esgotos entre}

1995 e 2004

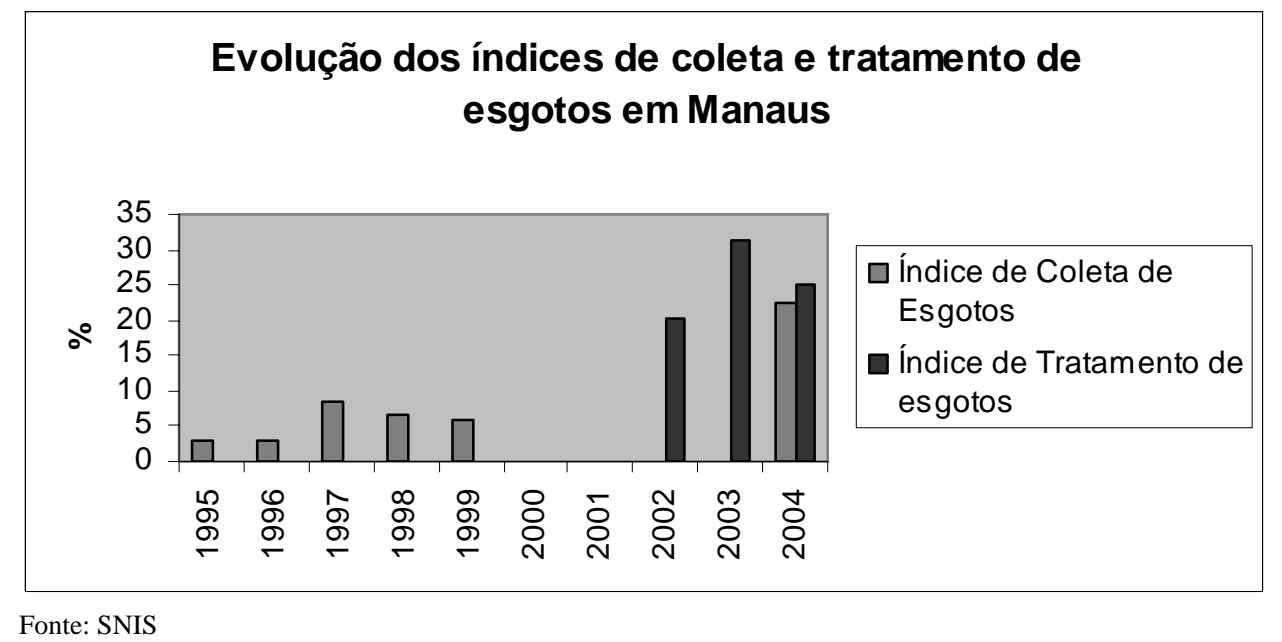

Os índices mostram grande oscilação no que diz respeito à coleta de esgotos no período em que os serviços eram prestados pela iniciativa pública e não havia tratamento para este esgoto coletado. Estranhamente, entre 2000 e 2002, período este coincidente com o da concessão dos serviços de saneamento básico à iniciativa privada, o SNI não apresentou dados e, apesar de nos anos anteriores não terem sido apontados investimentos em tratamento de esgotos, para os anos de 2002 e 2003 há informação de que havia, respectivamente $20,4 \%$ e $31,3 \%$ de tratamento de esgotos, não tendo sido informado o montante da coleta. Finalmente, em 2004, foram apresentados dados para a coleta e o tratamento de esgotos, que mostram um pequeno retrocesso no que diz respeito ao tratamento.

Neste sentido, a grande oscilação apresentada entre 2003 e 2004, pode ser explicada pelo aumento da população não acompanhada de investimentos em tratamento de esgotos, refletindo na redução dos índices. Segundo o IBGE, a população 
de Manaus cresceu 42,10\% entre 1996 e 2005, índice que deveria ter sido acompanhado de investimentos em serviços.

De qualquer modo, a ausência de uma freqüência confiável de dados sobre a evolução da coleta e do tratamento de esgotos, indica certo descaso em relação a estes serviços que, foram durante anos relegados por não trazer retorno financeiro imediato.

No que diz respeito à extensão das redes de coleta de esgotos, podemos afirmar que as informações também não parecem confiáveis já que, conforme é possível observar no gráfico a seguir, um ano antes da concessão dos serviços à iniciativa privada, as redes apresentaram um crescimento de 44\%, destacando-se enormemente dos números dos dois anos anteriores, em que não houve investimentos. Nota-se que após o redimensionamento das redes pela empresa Águas do Amazonas em 2000 (ano da concessão), os valores apresentados, quanto à extensão das redes, se aproximam mais daqueles apresentados em 1998.

\section{Gráfico 17}

Manaus. Evolução da extensão das redes de coleta de esgotos entre 1995 e 2006**

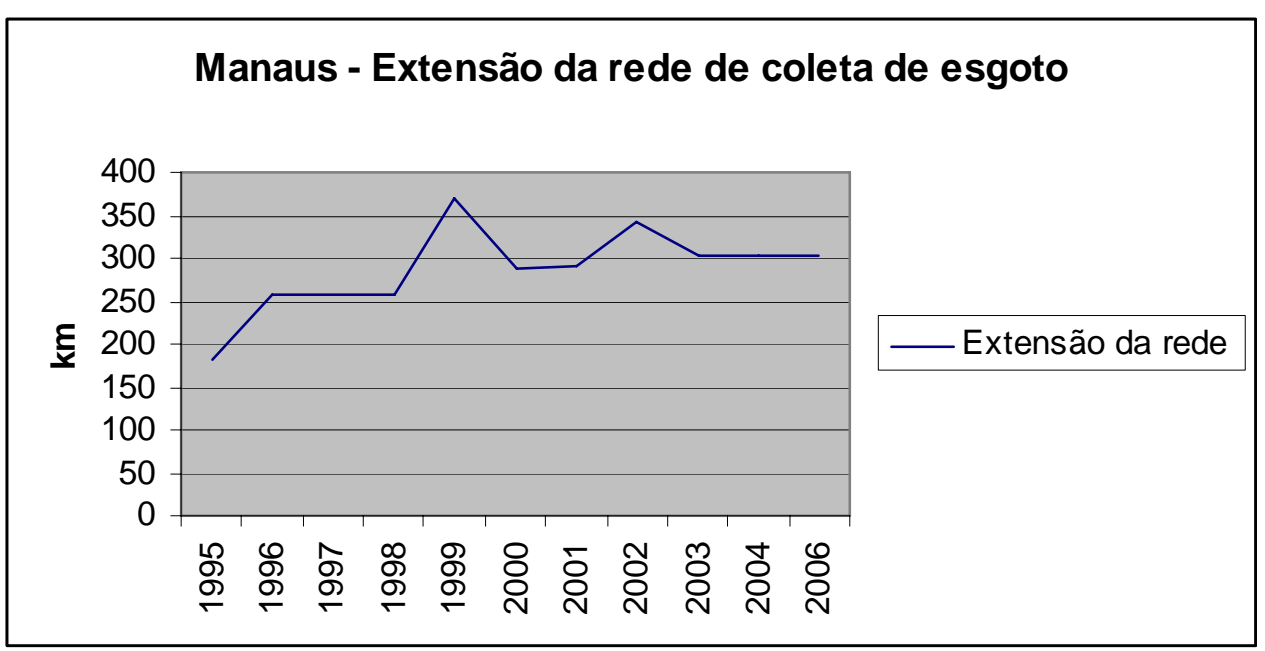

Fonte: SNIS. Diagnósticos anuais e ** site da empresa Águas do Amazonas, disponível em < http://www.aguasdoamazonas.com.br/empresa.php?nomeArquivo=numeros\&indiceMenuSelecionado=insti tucional > Acesso em 20/12/06.

Organização: Cristiane Fernandes de Oliveira

Ainda no que se refere às informações apresentadas sobre a extensão das redes, nota-se que as mesmas diminuíram cerca de 11\% entre 2002 e 2003 e tiveram seus investimentos paralisados desde então. 
A diminuição pode estar relacionada à deterioração das tubulações mais antigas e, sobre isto, a empresa alegou ter recebido as redes em precárias condições de manutenção. Contudo, mesmo sabendo da precariedade da rede, não foram efetuados investimentos que fossem capazes de suprir as perdas e muito menos ainda, no sentido de aumento significativo em infra-estrutura de novas redes. Esta estagnação de investimentos visível já a partir de 2002, portanto, a partir de dois anos após a concessão, indica certo comodismo por parte da concessionária, já que, em tese, a meta de investimentos em coleta de esgotos para 2006 já estaria cumprida, segundo o contrato firmado.

Cabe observar que os diagnósticos organizados e publicados pelo SNI são alimentados pelas informações fornecidas pelos prestadores de serviços, ou seja, pelas empresas públicas e privadas responsáveis pelos serviços.

Desta forma, a falta de cuidado com a elaboração dos dados sobre coleta de esgotos associada às metas vantajosas propostas e firmadas no contrato de concessão vêm ao encontro dos interesses da empresa Águas do Amazonas que incorporou obras já efetuadas pela iniciativa pública em seu plano de metas, desonerando-se dos mesmos.

Quem perde são os usuários que são condenados a conviver por mais tempo com cursos d’água poluídos e com a difusão de doenças.

Segundo o Ministério da Saúde, por meio do Departamento de Informática do Sistema Único de Saúde - DATASUS, 18,32\% dos óbitos em Manaus no ano 2004 estavam relacionados às doenças infecciosas e parasitárias, indicando uma possível ligação com a contaminação hídrica.

No questionário aplicado durante a pesquisa de campo, foi incluída uma questão que procurava reconhecer possíveis problemas de saúde vinculados ao consumo de água contaminada. O resultado da análise dos questionários em Manaus mostrou que 48\% da população entrevistada alegou já ter sido acometida de doenças gastrintestinais, com grande destaque para ocorrência de ameba.

A problemática da saúde, associada à degradação ambiental mobilizou o Ministério Público, que ingressou com Ação Civil Pública na tentativa de obrigar a empresa a efetuar os investimentos necessários em coleta e tratamento dos esgotos para adequação à legislação ambiental. Contudo, conforme as notas explicativas contidas nas demonstrações financeiras de 2005, divulgadas pela empresa, a mesma ampara sua defesa nas metas firmadas no contrato de concessão, que são inferiores ao exigido pela legislação ambiental em vigor. 
Quanto aos serviços de saneamento básico relacionados à coleta e ao tratamento de esgotos em Limeira, é possível observar no gráfico a seguir, que também há dúvidas em relação aos dos dados.

\section{Gráfico 18}

Limeira. Evolução do índice de coleta e tratamento de esgotos entre 1996 a 2004

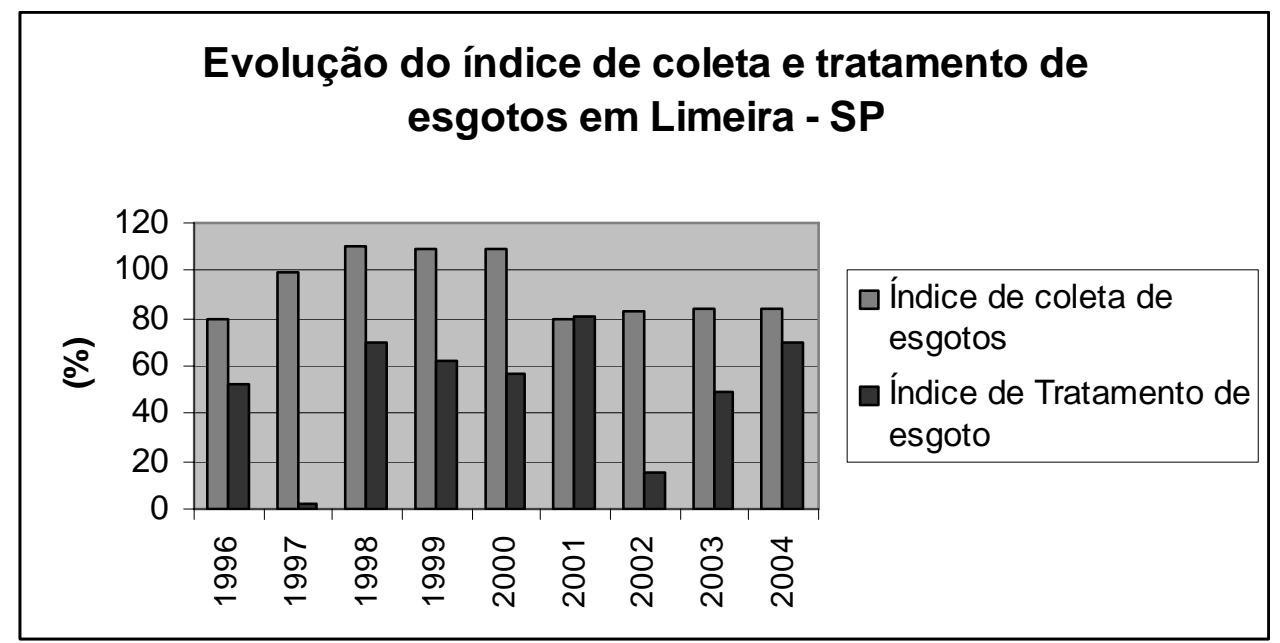

Fonte: Diagnósticos anuais SNIS / Organização: Cristiane F. de Oliveira

Para os anos 1998, 1999 e 2000 os índices de coleta de esgotos ultrapassam a marca de $100 \%$ o que denota ter havido erro nos cálculos. Também, há grande oscilação quanto aos índices apresentados para tratamento de esgotos, especialmente em relação ao ano de 1997 e 2002, que destoam fortemente dos demais anos, indicando que pode ter havido erro na apresentação destes índices ou o abandono no tratamento dos esgotos nestes anos, por motivo não informado.

Nota-se que além da questão do problema com os dados, os índices mostram que entre 1996 e 2004 a coleta de esgotos só evoluiu cerca de 5\% e o tratamento de esgotos cerca de 34\%. Deste modo, é possível perceber que as receitas obtidas a partir dos reajustes aprovados, após o acordo firmado com a Prefeitura de Limeira, em 2000, não priorizaram, neste período, a coleta e o tratamento de esgotos.

Como lembrou Justo (2004) a empresa Águas de Limeira recebeu em 1998 duas multas da CETESB por lançamento de esgotos in natura em corpos d’água, que na época se deveu às paralizações das obras da ETE - Tatu.

Neste sentido, em Limeira os problemas de contaminação ficam a cargo da poluição dos rios da Bacia do Piracicaba devido ao despejo de esgotos in natura nos 
corpos d’água. Em vista disto, só recentemente é que alguns esforços conjuntos estão sendo promovidos entre órgãos públicos e a empresa Águas de Limeira, no sentido de implementar os sistemas de tratamento de esgotos e diminuir os índices de contaminação.

Atualmente, segundo informa a empresa Águas de Limeira por meio de seu site na internet, atualmente a cobertura de esgotos é de $100 \%$ e o tratamento é de $70 \%$. Apesar do índice de tratamento de esgotos não ter se alterado desde 2004, houve uma evolução no aspecto da coleta, o que reflete na melhoria sanitária local.

No que concerne à difusão de doenças relacionadas à veiculação hídrica, que compromete principalmente as populações de baixa renda, não houve relatos de ocorrências, por parte da população entrevistada em campo.

Quanto à extensão das redes de coleta de esgoto os dados mostraram crescimento constante entre 1996 e 2004, o que demonstra que houve investimentos em infra-estrutura física, conforme pode ser observado na tabela a seguir.

\section{Tabela 13}

Limeira. Evolução da extensão da rede de coleta de esgoto entre 1996 e 2004

\begin{tabular}{||l|l|l|l|l|l|l|l|l|l||}
\hline & $\mathbf{1 9 9 6}$ & $\mathbf{1 9 9 7}$ & $\mathbf{1 9 9 8}$ & $\mathbf{1 9 9 9}$ & $\mathbf{2 0 0 0}$ & $\mathbf{2 0 0 1}$ & $\mathbf{2 0 0 2}$ & $\mathbf{2 0 0 3}$ & $\mathbf{2 0 0 4}$ \\
\hline $\begin{array}{l}\text { Extensão } \\
\mathbf{( K m )}\end{array}$ & 644 & 700 & 656 & 697 & 757 & 784 & 808 & 821 & 845 \\
\hline
\end{tabular}

Fonte: SNIS/Diagnósticos anuais

O crescimento da extensão das redes, no entanto, se deveu ao fato de ter havido grande reajuste das tarifas em 2000, que foram, parcialmente, destinadas à contratação de obras para fins de extensão da infra-estrutura de coleta de esgotos.

As tarifas reajustadas, é que financiaram e continuam a financiar estes investimentos e os relacionados ao abastecimento de água, onerando, por sua vez, as famílias mais pobres, que não contam mais com a possibilidade de subsídio cruzado.

No que concerne ao abastecimento de água, os serviços em Limeira e em Manaus são bastante diferentes, apesar de terem em comum a questão das altas tarifas, que em Limeira atingiu mais fortemente as camadas mais pobres da população, principalmente no ano em que ocorreu o reajuste, ou seja, entre 2000 e 2001. 


\section{2. $\mathrm{O}$ abastecimento de água}

Cabe destacar que 63\% da população entrevistada em Limeira classificou como altas as tarifas cobradas pelos serviços de água e esgoto. Contudo, como já abordado, em virtude do predomínio da alta renda per capta no município, a inadimplência não afeta demasiadamente a evolução dos investimentos.

Quanto a isto, para o caso de Manaus a situação é mais grave, devido à predominância de população economicamente mais pobre. Entre a população entrevistada 57\% afirmaram que o preço das tarifas era alto. As taxas de inadimplência são altas e, tendo em vista os cortes de abastecimento pelo não pagamento, a forma de obter água se apresenta por meio dos denominados "gatos”. As ligações clandestinas às redes, com conexão de mangueiras ou encanamentos improvisados nas adutoras são muito comuns em Manaus, especialmente nos bairros onde há grande intermitência no abastecimento, fato este usado como argumento para a utilização deste mecanismo.

A foto a seguir procura ilustrar o uso de "gato” com conexão à adutora por meio de mangueira.

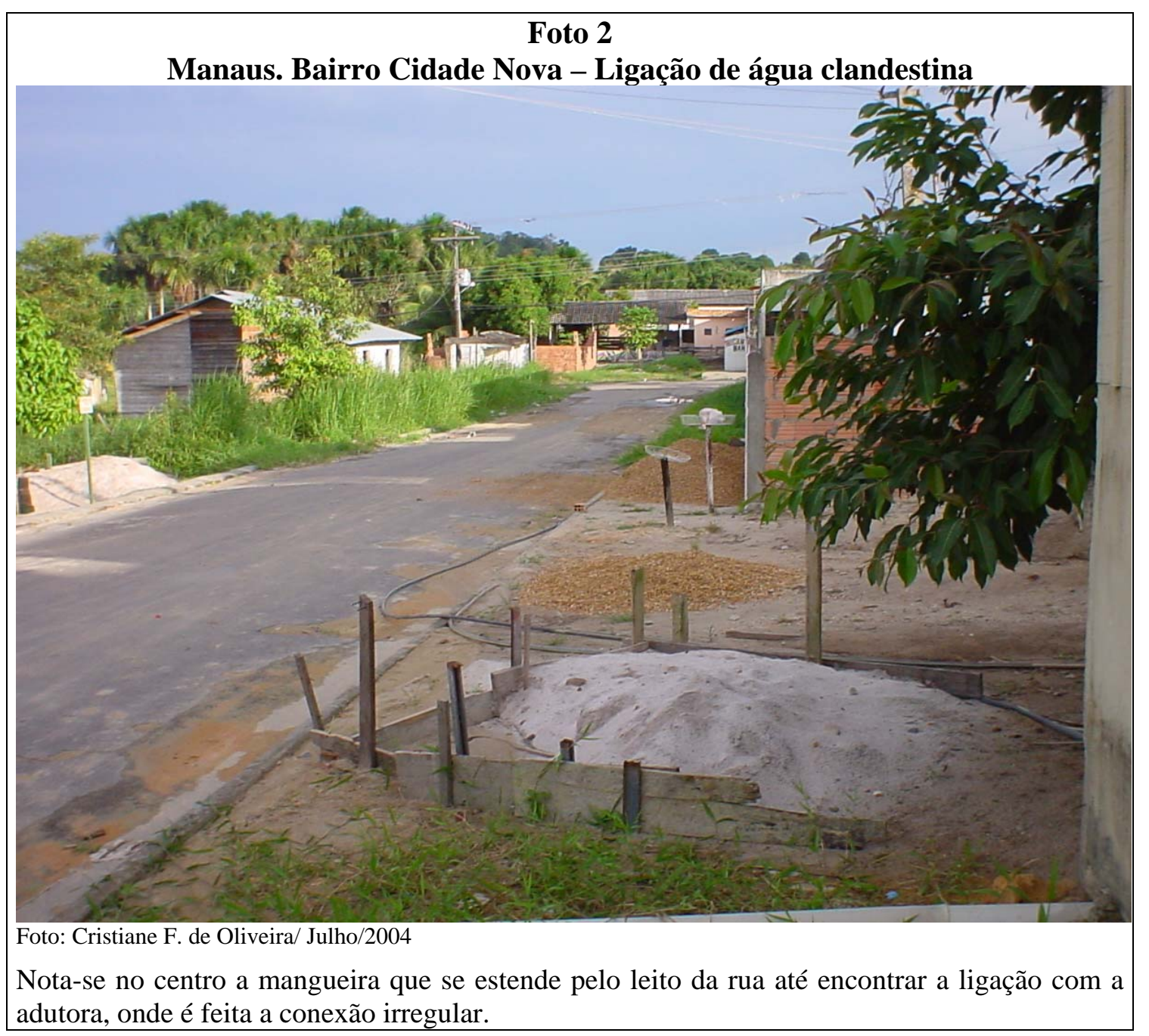


Nota-se que as irregularidades em relação à obtenção de água por meio dos chamados “gatos” tem se perpetuado desde a gestão pública até a atual em Manaus. Deste modo, os índices de perda de água na distribuição da rede em Manaus continuam altos, sendo que para o ano de 2004 os índices apontados foram de 71\%.

O índice de perda de água na distribuição da rede se refere aos volumes de água tratada perdidos, devido a problemas de vazamentos nas tubulações da rede e obtenção de água de forma irregular (gatos).

Enquanto a empresa Águas do Amazonas culpa os “gatos” pelos altos índices de perda, uma parcela da população assume o artifício como única maneira de driblar a falta de acesso à água tratada. Isto criou um impasse que tem levado ao abandono grandes parcelas da população, quanto à qualidade dos serviços, à extensão da irregularidade, bem como o aumento de prejuízos para a concessionária privada pela perda de água tratada.

Com relação à água tratada oferecida por meio das redes, tanto Manaus como Limeira conta atualmente com sistema de tratamento adequado.

Em relação às análises efetuadas pelo Instituto Adolfo Lutz em Limeira, não houve casos de amostras fora do padrão de potabilidade e microbiológico para as áreas atendidas por água da rede. O único caso em desacordo com as normas e padrões de potabilidade estava relacionado à água obtida de um poço artesiano sem tratamento.

Por sua vez, para o caso de Manaus foram encontrados 2 casos de amostras coletadas em domicílios ligados à rede em desacordo com os padrões de potabilidade exigidos, situados nos bairros de Santa Etelvina e Santo Antonio. Estes casos estavam em desacordo, respectivamente, em relação à presença de coliformes e da cor acima do padrão tolerado.

Também tivemos acesso a alguns laudos, também analisados pelo Lacen de Manaus, solicitados pela Secretaria de Vigilância Sanitária de Manaus, que nos forneceu informações, principalmente, sobre a situação da água de poços do município.

Entre estas amostras foram encontrados vários casos em desacordo com os padrões. Cabe observar, porém, que grande parte destes casos foram corrigidos posteriormente, com o tratamento da água, já que se tratavam em grande parte de órgãos públicos, como hospitais, postos de saúde ou conjuntos habitacionais que a vigilância sanitária acompanhava periodicamente. A grande maioria dos poços perfurados em Manaus, no entanto, como já mencionado, não possui controle algum. 
É importante mencionar que os laudos emitidos pelo Lacen, os quais detectaram qualidade da água em desacordo quanto à potabilidade da água, se baseiam nos parâmetros químicos e físicos definidos por norma legal específica. Estes parâmetros são vários e podem ser apreciados nos próprios laudos anexos, destacando-se a cor, odor, presença de coliformes fecais, presença de amônia, ph, quantidade de cloro, quantidade de sulfeto, entre outros.

Deste modo, a partir do laudo emitido pelo Lacen para a Secretaria de Vigilância Sanitária, foi possível contatar que nos poços que estavam em desacordo com as normas legais sanitárias, foram observados a presença de coliformes fecais, alta presença de amônia, ph e cloro abaixo do limite e sulfeto acima do limite. Os bairros onde foram constatadas as irregularidades quanto à água destes poços são os seguintes: Ponta Negra, Zumbi dos Palmares, Japiim, Flores, Cachoeirinha, São José Operário, Aleixo e D.Pedro I.

Ainda em relação aos laudos solicitados pela Secretaria de Vigilância Sanitária de Manaus, foi constatada a presença de coliformes em água coletada da rede no bairro Oliveira Machado.

Entre as amostras coletadas em nossa pesquisa de campo, foram detectados dois casos em desacordo com as normas ${ }^{57}$, em ambos a água foi coletada no cavalete de entrada de água da rua. No caso do domicílio situado no bairro de Santa Etelvina foi detectada a presença de coliformes fecais e PH abaixo do limite permitido e no caso do domicílio localizado no bairro de Santo Antonio a cor se apresentava acima do valor máximo permitido e o cloro residual livre inferior ao exigido.

Ao mapearmos estes bairros, conforme a seguir, notamos que não há uma área específica de concentração dos mesmos, indicando a possibilidade de disseminação da contaminação hídrica, especialmente no que concerne a água de poços.

\footnotetext{
${ }^{57}$ Dispostos nos anexos deste trabalho.
} 


\section{Mapa 10}

Manaus. Ocorrência de casos de abastecimento de água em desconformidade com os padrões de potabilidade exigidos pelo Ministério da Saúde segundo os bairros

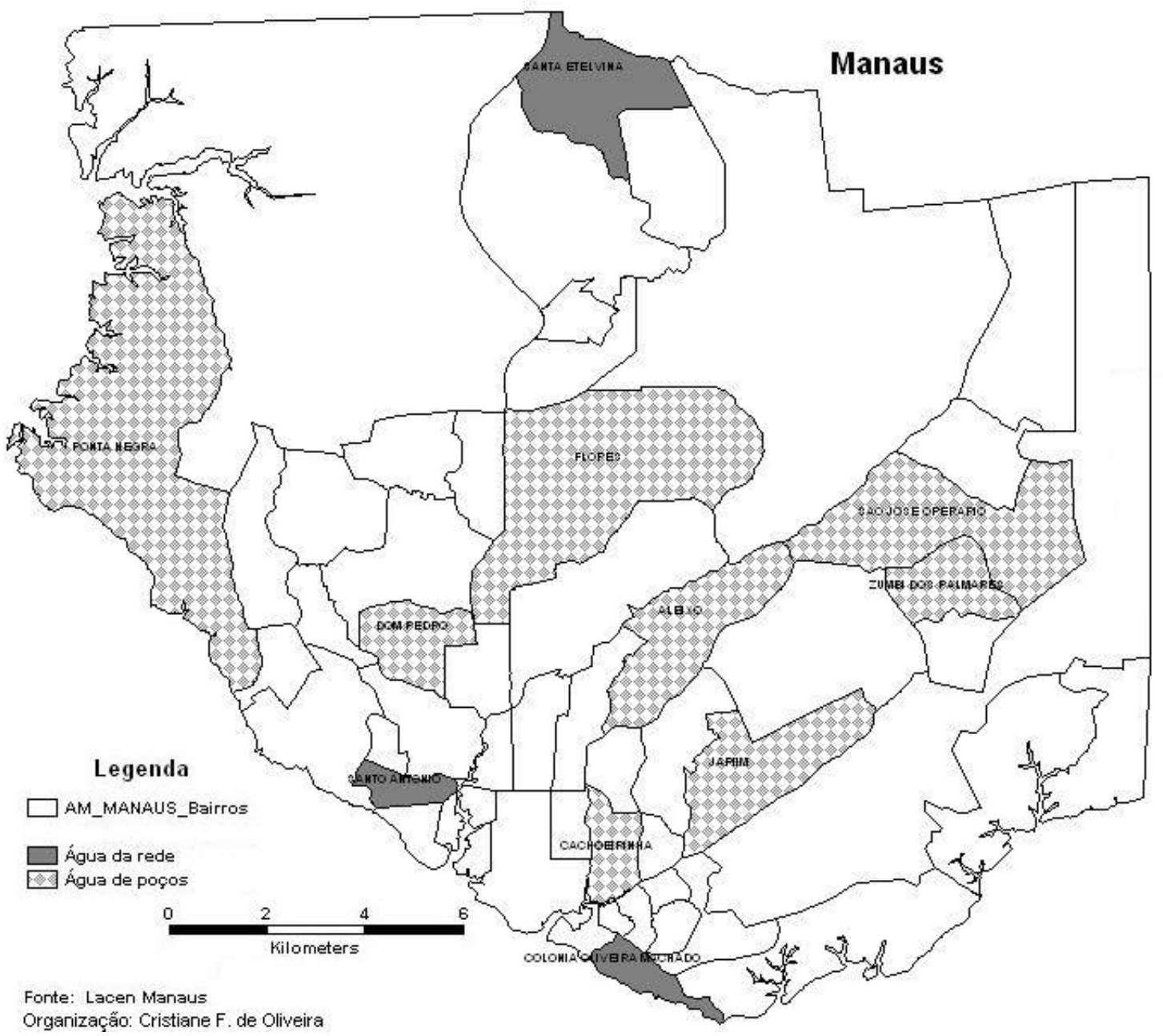

Os casos constatados em desconformidade de potabilidade em rede podem ter sido ocasionados devido a intermitência do abastecimento, que suspende material depositado nas tubulações e também podem ter ocorrido devido às falhas no processo de descontaminação, especialmente no que diz respeito aos reservatórios públicos.

Estas falhas já teriam sido apontadas por Oliveira et al. (2001) que observou uma série de problemas com os reservatórios do sistema de distribuição de água na cidade de Manaus, apontando que destes, 54\% estariam em péssimo estado de conservação, o que poderia concorrer para a contaminação da água distribuída. 
Em relação à evolução do tratamento de água, o SNIS nos fornece dados que indicam um crescimento dos volumes tratados, em Manaus, conforme a seguir. Contudo, nota-se que houve redução dos dados para o ano da concessão, em 2000, o que deve estar relacionado ao período de transição envolvendo a passagem dos serviços prestados pela empresa pública à empresa privada.

\section{Gráfico 19 \\ Manaus. Volumes de Água tratados em Estações de Tratamento de Água $\left(\mathrm{p} / \mathbf{1 0 0 0 \mathrm { m } ^ { 3 } / \mathrm { ano } )}\right.$}

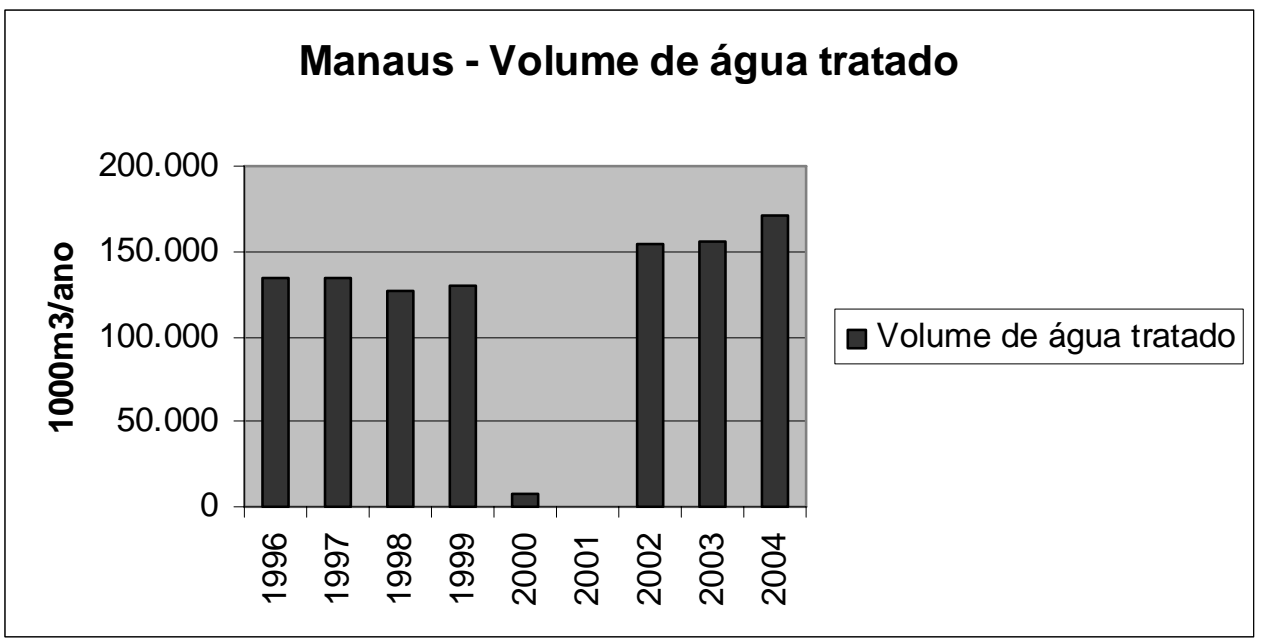

Fonte: Sistema Nacional de Informações - SNIS

Organização: Cristiane F. de Oliveira

A tabela mostra uma queda no tratamento de água entre o período de 1996 e 1998 e uma retomada do tratamento em 1999. Em 2000 os valores destoam totalmente dos demais, indicando problema com os dados, bem como em 2001 não foram apresentados dados sobre tratamento de água. Contudo, finalmente entre 2002 e 2004 houve um crescimento de $10 \%$ nos volumes de água tratados, sendo que é possível inferir que em relação ao tratamento de água houve avanços.

Em relação à extensão das redes de água os dados publicados pelo SNIS deixam margens a dúvidas, já que apresentam grande oscilação dos valores. Como se trata de infra-estrutura física é possível considerar que haja certa perda, devido à precariedade das tubulações mais antigas, mas não nas proporções apresentadas, como pode ser observado a seguir. 
Gráfico 20

Manaus. Evolução da extensão da rede de abastecimento de água entre 1996 e $2004(\mathrm{Km})$

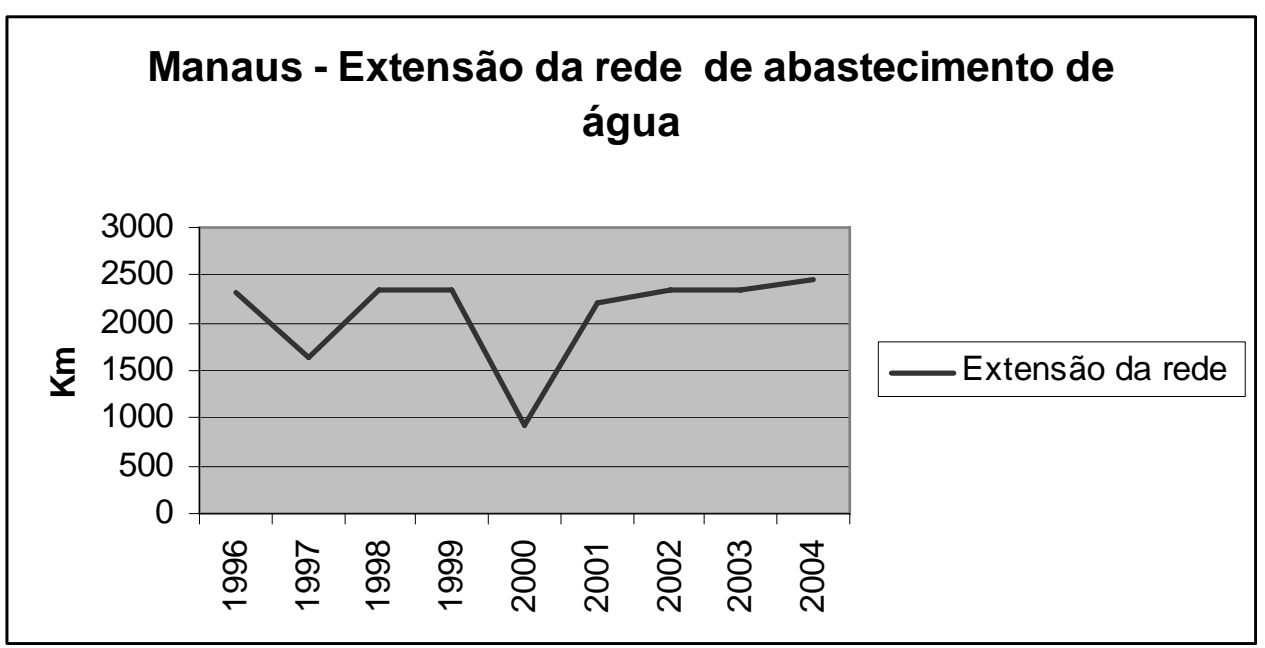

Fonte: Diagnósticos anuais SNIS / Organização: Cristiane F. de Oliveira

As redes apresentaram redução entre 1996 e 1997 e entre 1999 e 2000, esta última bastante significativa, coincidindo com o ano em que houve a concessão. Somente a partir de 2001 é que passa a ser observado crescimento das redes, sendo que entre 1996 e 2004 o crescimento absoluto do período foi de cerca de 5\%.

Quanto à cobertura de abastecimento de água nota-se por meio do gráfico a seguir grande oscilação dos índices, com tendência a diminuição em 2004.

\section{Gráfico 21}

Manaus. Evolução da cobertura de água entre 1996 e 2004

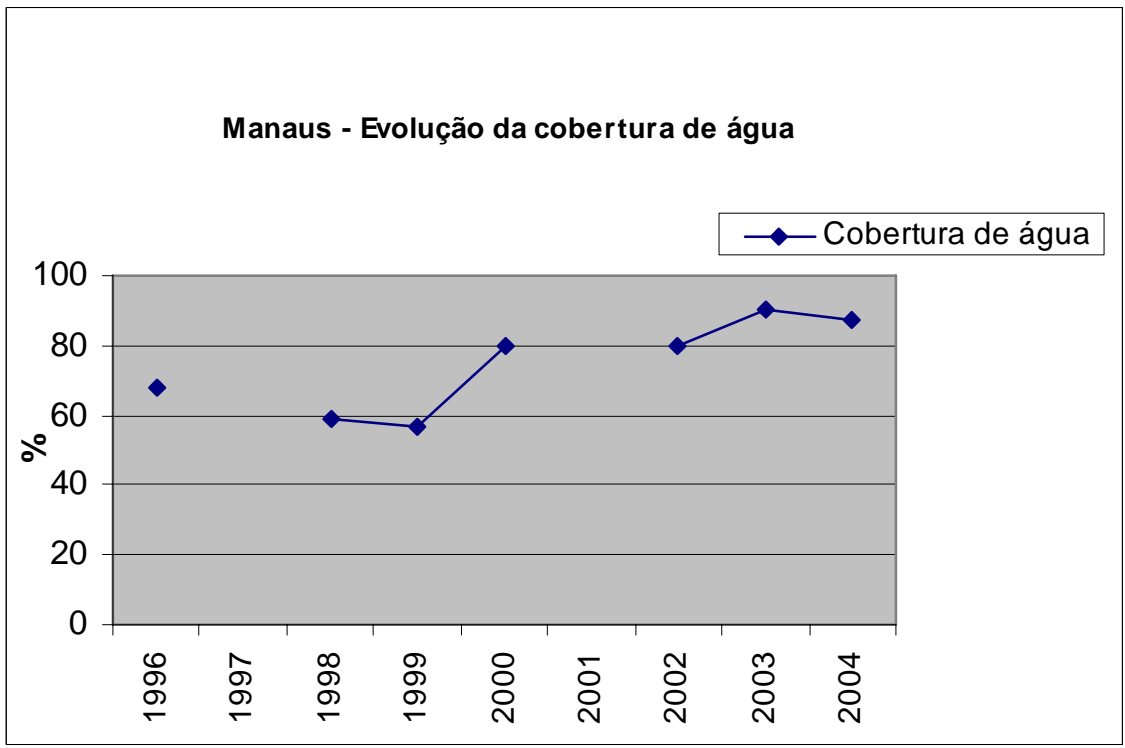

Fonte: Diagnósticos anuais SNIS 
Segundo a empresa Águas do Amazonas ${ }^{58}$ em 2006 o índice de cobertura de água atingira $87 \%$. Contudo, as metas firmadas no contrato de concessão previam para este mesmo ano a cobertura de 95\% da população, que não foram atingidas.

Nota-se também que além da empresa não ter conseguido atingir a meta prevista, nos dois últimos anos praticamente não houve investimentos em ampliação da cobertura de água, já que em 2004, os índices eram praticamente os mesmos de 2006.

No que se refere à evolução da extensão das redes de abastecimento de água em Limeira pode-se afirmar que com exceção dos dados para o ano de 1997, que apresentou redução, há uma tendência ao crescimento.

Deste modo, o gráfico a seguir procura mostrar a evolução da extensão da rede em Limeira.

\section{Limeira: Evolução da extensão da rede de abastecimento de água entre 1996 e 2004}

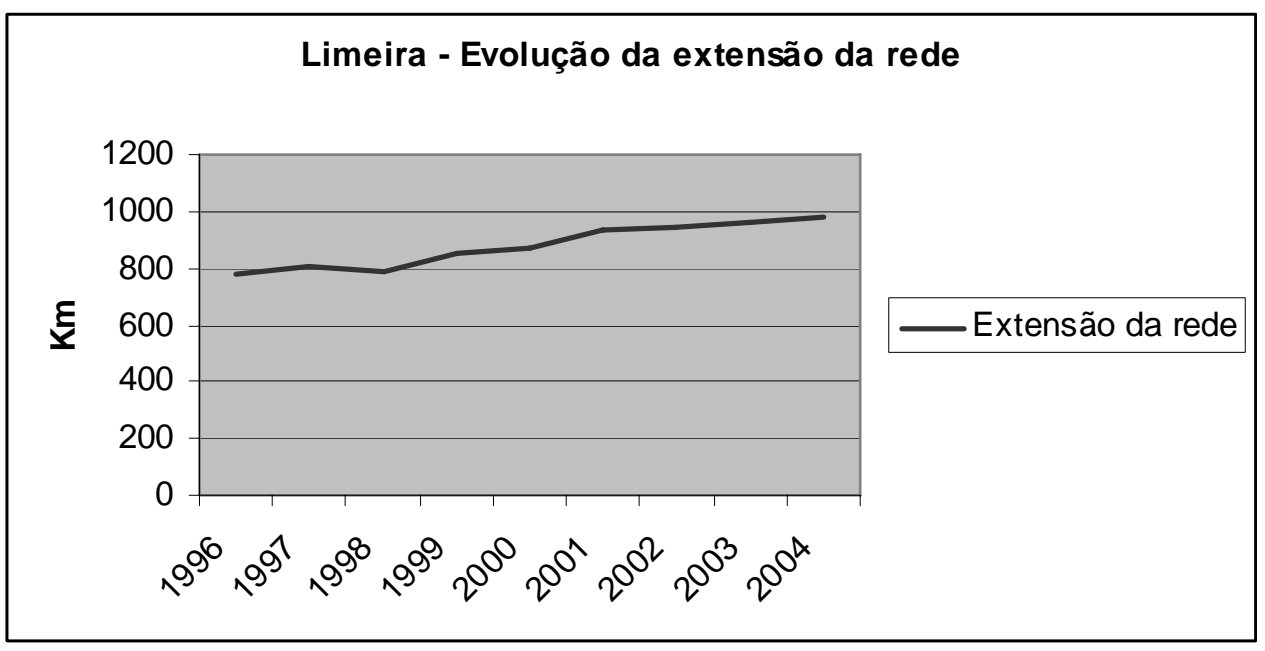

Fonte: Diagnósticos anuais SNIS.

O crescimento das redes significa melhoria na cobertura de água e, sem dúvida o crescimento da extensão das redes de abastecimento de água em Limeira possui reflexos positivos na cobertura de água. No entanto, apesar dos altos índices de cobertura de água em Limeira, em 2004 houve uma redução em relação a 2003. Em 2003 o SNIS revelou 100\% de cobertura de água em Limeira e, em 2004, o índice caiu para 95,5\%.

58 ÁGUAS DO AMAZONAS. Números e Indicadores de dez/2006. Disponível em: < http://www.aguasdoamazonas.com.br/empresa.php?.nomeArquivo=numeros\&indiceMenuSelecionado=in stitucional > Acesso em 05/12/2006. 
Esta queda pode ter inúmeras razões, desde problemas com as redes, aumento da demanda ou diminuição dos volumes de água captados e tratados.

Cabe destacar que houve redução, também entre 2003 e 2004, dos volumes de água aduzidos e tratados, conforme ilustra o gráfico a seguir, que podem explicar a redução no índice de cobertura de água.

\section{Gráfico 23}

\section{Limeira. Evolução dos volumes de água aduzidos e tratados em ETA entre 1996 e 2004}

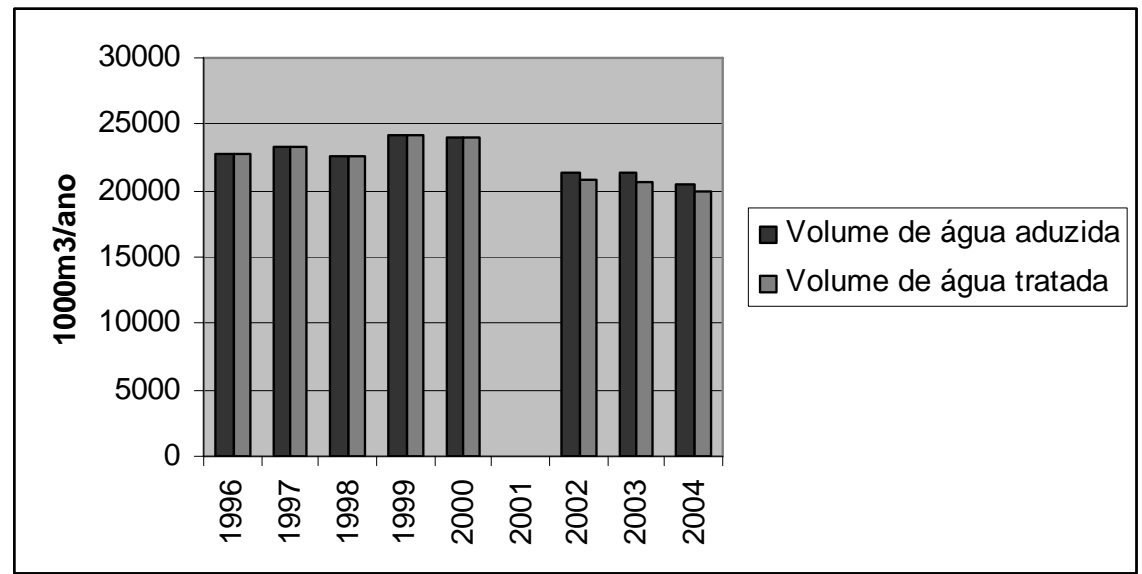

Fonte: Diagnósticos anuais SNIS

É importante lembrar que no ano de 2003 houve grande estiagem que comprometeu o abastecimento em várias cidades, entre as quais aquelas que dependiam da produção hídrica de rios da Bacia do Piracicaba para seu abastecimento, como é o caso de Limeira e da Região Metropolitana de São Paulo - RMSP.

A redução da oferta de água em 2003 provocou a mobilização de representantes de vários municípios da bacia de Piracicaba, com o objetivo de cobrar ações do governo do Estado para a diminuição dos volumes exportados dessa bacia para a RMSP.

Deve ser observado que não somente o período de estiagem contribuiu para esta pendenga, mas também a crescente demanda por água por parte dos municípios situados nesta bacia, resultando, em 2004, em um acordo, no qual foi previsto um plano de redução paulatina da exportação de água para a RMSP.

Enquanto os planos de redução da exportação de água não são implementados, a situação de abastecimento dos municípios que dependem da água da mesma Bacia Hidrográfica, ficou comprometida. Neste sentido, a redução de adução pode ter uma relação direta com este contexto. 
Ainda, a estiagem e a redução de disponibilidade de água para abastecimento concorreram também para que fossem disseminados mecanismos de economia de água, não somente entre os usuários, mas entre as próprias empresas responsáveis pelo abastecimento.

A redução do consumo passou a ser uma meta, e foi estimulada não somente pelo comitê de Bacia PCJ, mas pelas próprias instâncias municipais que partilham a água. Deste modo, a racionalidade do consumo passou a ser cobrada.

Há duas formas de se avaliar a racionalidade do consumo de água, uma está relacionada ao cuidado com as redes, sendo que podemos saber qual é a política da empresas, neste sentido, com a avaliação das perdas de água na distribuição e, a outra, se relaciona à avaliação do comportamento dos usuários quanto ao consumo de água.

Em relação às perdas na distribuição, Manaus já apresentava em 1998 altos índices, sendo o mais alto do país com perdas de 63\% da água aduzida. Em 1999, o SNIS divulgou uma pequena diminuição destas perdas, contudo, devemos considerar o fato de que a empresa estava sendo preparada para a concessão e, portanto, a minimização das perdas seria interessante de ser apresentada.

É importante dizer que com a atuação privada, os índices de perdas na distribuição em Manaus aumentaram ainda mais, chegando em 2004 a 71\%.

No caso de Limeira, ao se examinar a evolução dos índices publicados pelo SNIS, pudemos constatar que houve uma redução gradativa das perdas, até em 2004 alcançar 17,2\% um bom índice de perda na distribuição comparado aos índices de outras empresas no restante do Estado de São Paulo, conforme dados do SNIS.

A tabela a seguir procura apresentar os índices de perda na distribuição de água da rede por parte de alguns municípios do Estado de São Paulo. 
Tabela 14

Índice de perda de água na rede em municípios do Estado de São Paulo no entorno de Limeira (2004)

\begin{tabular}{||l|l||}
\hline \hline Município & Índice de perda (\%) \\
\hline Limeira & 17,2 \\
\hline Americana & 30,6 \\
\hline Indaiatuba & 42,9 \\
\hline Piracicaba & 50,5 \\
\hline Rio Claro & 37,0 \\
\hline Municípios operados pela Sabesp & 43,1 \\
\hline
\end{tabular}

Fonte: SNIS/2004

Deste modo, buscando compreender o quanto a questão da racionalização da água foi internalizada pela população consumidora de água em Manaus e Limeira é que procuramos avaliar o comportamento de consumo dos usuários. Adotamos os dados da Sabesp para a comparação por ela atender grande parte dos municípios do Estado de São Paulo e ser uma empresa de porte regional, que também atende a capital, sendo, portanto, representativa.

Gráfico 24

Evolução do consumo de água per capta em Manaus, Limeira em municípios atendidos pela Sabesp entre 1995 e 2004

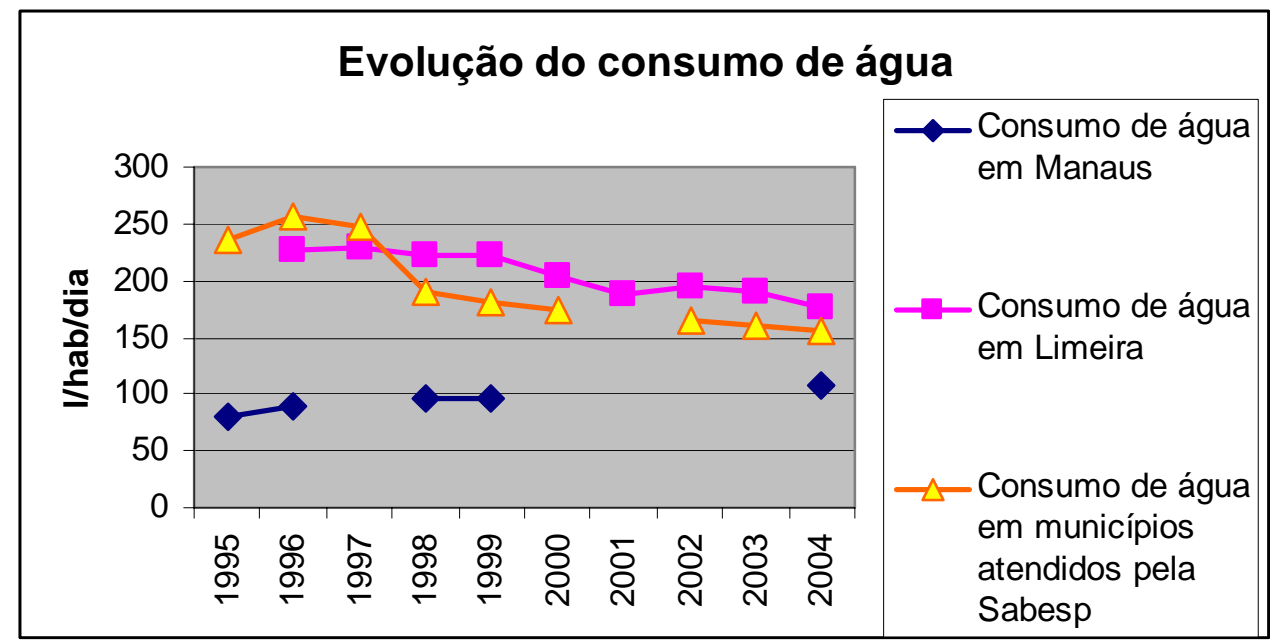

Fonte: Diagnósticos anuais do SNIS

Estas informações nos mostram que enquanto para os casos de Limeira e dos municípios atendidos pela Sabesp houve uma tendência ao decréscimo do consumo per 
capta, em Manaus o consumo apresenta um pequeno crescimento. Contudo, os volumes consumidos em Limeira são mais altos entre os demais comparados, indicando que há necessidade de promoção de medidas voltadas à economia de água.

Durante a pesquisa de campo a população amostrada foi questionada sobre a lembrança da existência de campanhas educativas, que visavam economia de água, na cidade pesquisada. Os resultados obtidos, a partir da tabulação dos questionários aplicados, em Manaus e Limeira, indicaram a ausência de investimentos em conscientização da população para uso racional da água.

Em Manaus, 67\% da população entrevistada não conseguiu lembrar de nenhuma forma de campanha com o objetivo de economia de água. Dos 27\% que lembravam somente 9\% relacionou a campanha à empresa, os demais relacionaram a campanha aos órgãos públicos, tais como escolas, Prefeitura ou igreja católica, citando-se o tema da campanha da fraternidade da igreja católica em 2004 que tratava o tema da água.

Em Limeira, 61\% das pessoas entrevistadas também não lembravam de nenhuma campanha sobre economia de água e entre a população total que lembrava somente 28\% relacionava a campanha à empresa. Os demais relacionavam a campanha aos órgãos públicos ou à campanha da fraternidade.

É interessante notar que ainda que Manaus possua uma tendência ao crescimento do consumo de água, a média de consumo per capta ainda é muito inferior às médias per capta de Limeira ou de São Paulo. Isto de certo modo, é reflexo da restrita capacidade de pagamento da população e, portanto da capacidade de comprometimento do orçamento familiar com altas tarifas de água. É importante lembrar que 57\% das pessoas entrevistadas classificaram como alta ou abusiva as tarifas cobradas pelo consumo de água.

Além das altas tarifas, o aumento da clandestinidade nas ligações de água (os gatos) também contribui para os baixos índices de consumo per capta, já que mesmo consumindo água da rede, a população consumidora clandestina não é contabilizada, sendo que a água consumida é considerada perdida na distribuição.

O baixo consumo per capta também indica problemas no próprio sistema de abastecimento de água. Em relação a isto foi possível notar, em campo, que muitos dos entrevistados se queixavam da intermitência no suprimento de água por redes. No entanto, há várias lacunas sobre este tópico, nos dados publicados pelo SNIS, que por sua vez foram alimentados pelas informações concedidas pelas concessionárias responsáveis pelos serviços. 
Em relação à percepção da população entrevistada sobre a qualidade da água os resultados mostram que em Manaus 51\% da população considerava a qualidade da água boa, 39\% consideravam a qualidade regular e 10\% consideravam ruim. Contudo, vários entrevistados que classificaram a água como sendo boa não bebiam a água da rede, optando por outras fontes.

De acordo com os questionários aplicados, 54\% dos entrevistados que classificaram a água como sendo boa, traziam em seu discurso incoerências quando afirmavam que a água apresentava odor e cor fora dos padrões aceitáveis. Em geral, ainda predomina a percepção de que a água de poços (não incluídos na rede) ou a água comprada em galões é de melhor qualidade.

A foto a seguir procura retratar um fato muito comum nos bairros de Manaus: a busca de água em bicas públicas para consumo direto, por parte da população local. Estas bicas estão em geral localizadas em prédios públicos e são alimentadas por poços.

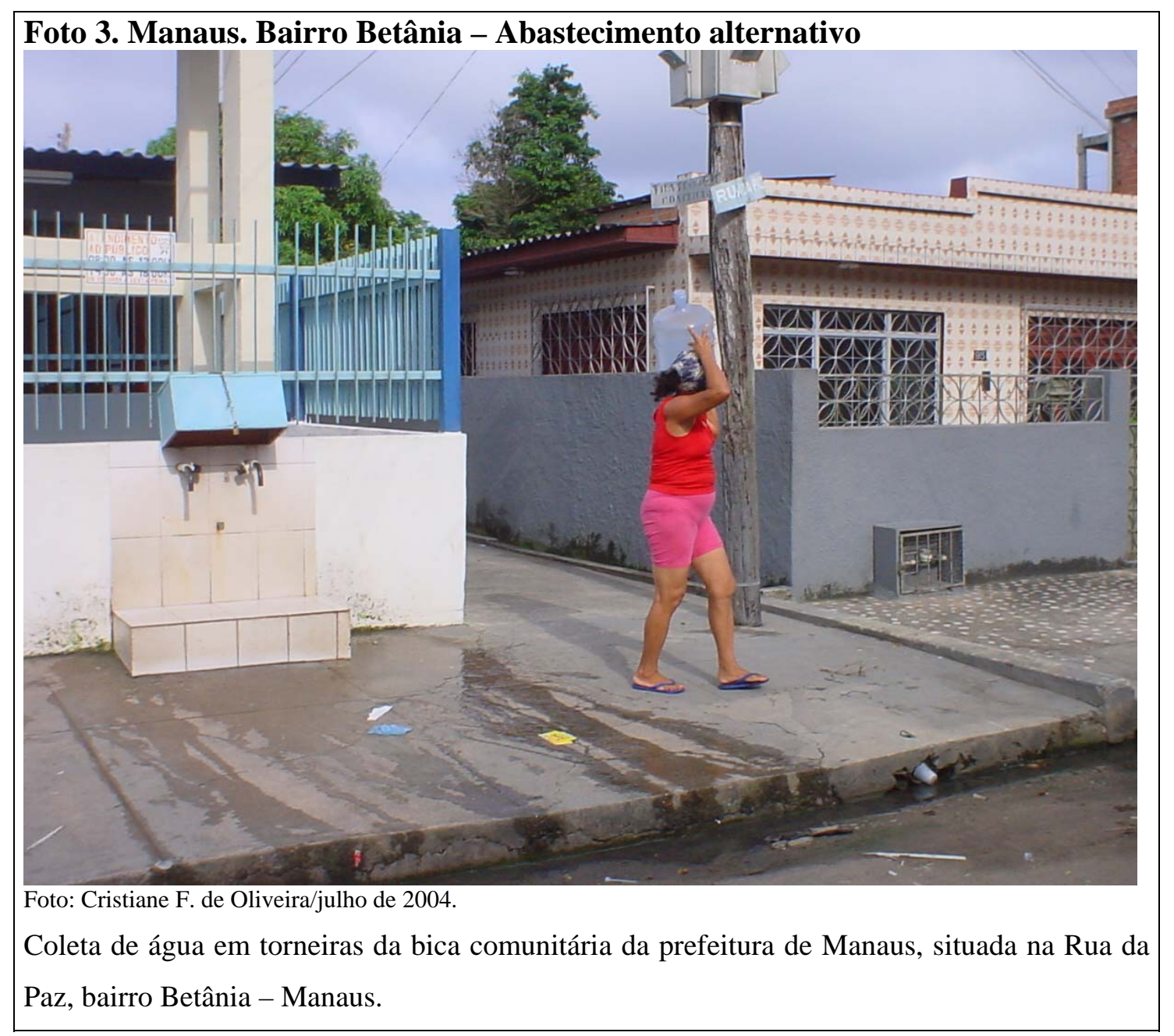


A partir de todas as análises desenvolvidas é possível destacar algumas situações que marcam as concessões dos serviços de saneamento básico em Manaus e em Limeira.

Para o caso de Manaus a análise da evolução dos dados indica que há muitas lacunas de informações e dados cujos valores destoam fortemente da evolução dos demais para o ano 2000, ano da concessão, devendo ser considerado o período de transição onde ocorreu a transferência das atribuições da empresa Cosama à Águas do Amazonas. Estas lacunas e erros podem ter sido deixadas em função do momento de adaptação às exigências burocráticas por parte da empresa privada que assumiu a gestão e operação dos serviços. Contudo, é possível também que tenha havido manipulação para fim de sucateamento da empresa, principalmente no que concerne aos dados apresentados para o ano de 1999, ou seja, um ano antes da concessão.

Deste modo, foi possível compreender que para o caso de Manaus houve grandes avanços no que diz respeito a qualidade do tratamento da água, com a aplicação de novas tecnologias para eliminação da coloração escura, oriunda da matéria orgânica presente no rio Negro, de onde provém a maior parte da água distribuída. Contudo, o ritmo de investimentos em extensão das redes e na cobertura de abastecimento de água não tem acompanhado as demandas, sendo que a meta contratual quanto à cobertura de abastecimento para o ano de 2006, que era de 95\%, não foi cumprida.

Em relação ao abastecimento também há muito que ser feito no que concerne aos cuidados com a manutenção das redes, para solucionar o problema das altas taxas de perdas na distribuição.

Por sua vez, a empresa alega que grande parte das perdas se deve ao "roubo" de água por meio dos "gatos” na rede e da necessidade de substituição das tubulações, as quais se encontram em precárias condições de manutenção.

Se por um lado, há grande número de ligações clandestinas na rede, por outro a empresa tem aplicado taxas altas à população, como já foi discutido no capítulo II. Estas altas tarifas aplicadas à medida que procuram cobrir os custos com a inadimplência, por outro mantém um ciclo vicioso, que exclui do acesso regularizado grande parte da população que não pode pagar.

Em relação ao argumento sobre a precariedade das redes e a necessidade de investimentos, pode-se afirmar que este foi um dos motivos que levou o Estado a conceder os serviços à iniciativa privada, já que buscava ser desonerado destes custos. Este fato, certamente, foi considerado previamente às concessões por parte da iniciativa 
privada e já deveriam ter sido computados como custos de investimentos necessários à melhoria dos serviços.

Além dos déficits na cobertura e da precariedade das redes do sistema de abastecimento de água, a população de Manaus tem convivido há anos com os esgotos gerados e lançados sem tratamento no solo ou nos corpos d’água. A insuficiência de redes de coleta de esgotos tem marcado a paisagem das ruas de Manaus que invariavelmente apresentam sarjetas de águas pluviais contendo esgotos in natura.

A contaminação hídrica de cursos d’água e igarapés, bem como de recursos hídricos subterrâneos, devido a falta de tratamento dos esgotos lançados, tem concorrido para a proliferação de doenças veiculadas pela água e para os altos índices de óbitos relacionadas às doenças infecciosas e parasitária, conforme apresentado no Banco de Dados do Sistema Único de Saúde - Datasus ${ }^{59}$.

Os grandes déficits apontados em abastecimento de água frequentemente implicam em pressões por busca deste recurso em outras fontes, como em reservas de água subterrânea ou mesmo o consumo de água contaminada e, também, em risco de super-exploração dos recursos hídricos subterrâneos com conseqüente diminuição dos volumes passíveis de consumo, como exposto por Hirata (2002).

Mesmo frente a todos estes déficits, na elaboração do contrato de concessão se procurou proteger a empresa concessionária, proporcionando a ela um prazo ainda maior para o início dos investimentos, tendo em vista que as metas para 2006, no que concerne à coleta de esgotos, já estavam cumpridas neste ato.

O resultado disto foi a ausência de investimentos em ampliação das redes coletoras desde 2003, o que perpetua a situação de insalubridade e aumento de riscos para a saúde pública local.

Em relação à articulação entre as políticas públicas em Manaus, observa-se que a concessão dos serviços à iniciativa privada só concorreu para uma maior fragmentação de informações necessárias à tomada de decisão. Deste modo, não só o Estado, por meio de suas instâncias públicas locais, relacionadas à gestão urbana e à saúde, ficou alijado de instrumentos de ação relacionados aos serviços de saneamento básico, como a

${ }^{59}$ Datasus. Índice de mortalidade/2003. Disponível em: < http://www.datasus.gov.br $>$ Acesso em nov/2006. 
empresa não dispôs de apoio quanto às políticas de controle e gestão do solo urbano. Neste sentido, pudemos notar que o crescimento da cidade se consolida a despeito da ocorrência de serviços essenciais, como os de saneamento básico, bem como os serviços de abastecimento de água, coleta e tratamento de esgotos não se estruturam em direção ao atendimento das demandas.

Em Limeira os serviços apresentaram avanços, principalmente no que diz respeito ao abastecimento de água e é possível afirmar que ao contrário da Águas do Amazonas, nota-se a evolução dos investimentos em melhoria dos serviços. Contudo, para que isto fosse viabilizado houve fortes pressões por parte da empresa para a autorização de aumentos das tarifas entre 1996 e 2000. É importante lembrar também que os conflitos entre a nova gestão de governo da prefeitura de Limeira e a empresa neste período, provocaram o atraso de 4 anos no cumprimento das metas de investimentos.

Ainda, não se deve deixar de lembrar que quando os aumentos foram autorizados, grande parte da população de menor renda não foi incluída no programa de subsídios, como exposto por Vargas e Lima (2004).

Deste modo, apesar de atualmente a empresa apresentar bons índices de atendimento e evolução de investimentos que condizem com as metas previstas, sua atuação passada não é imaculada.

Também permanece a dúvida sobre qual seria a evolução dos serviços se a Prefeitura ainda fosse a responsável. Apesar de não ser possível saber se os serviços teriam alcançado os índices atuais, havia indicação de que os mecanismos de desenvolvimento do setor estavam sendo implementados pelo órgão público responsável antes da concessão. Como observado por Justo (2004) as soluções adotadas com a participação ativa de representantes do setor produtivo local no financiamento do tratamento dos esgotos já obtinham sucesso antes da concessão, indicando que esta última, foi impulsionada mais em função do alinhamento, do então prefeito, às políticas neoliberais do que por falta de alternativa propriamente dita.

No que se refere ao consumo de água per capta, Limeira encontra-se em uma posição intermediária, apresentando índices mais altos do que os dos municípios atendidos pela companhia Sabesp, que são vários no Estado de São Paulo, mas inferiores em relação à Campinas e Americana, situados na mesma região.

Contudo, considerando que até o momento há grande dependência da água do rio Jaguari, pertencente à Bacia do rio Piracicaba, para abastecimento e que esta bacia 
tem sido, cada vez, mais comprometida com novas demandas de consumo, a implementação de medidas que visam a redução do consumo é importante. Neste sentido, no que concerne à conscientização da população usuária quanto à necessidade de economia de água, ainda há o que ser feito.

A economia de água, porém, não atende aos interesses da empresa, já que significaria uma redução das receitas e, portanto, as campanhas educativas passam a ser encargo do Estado.

Quanto a isto, os investimentos em campanhas educativas que almejam a redução das taxas de consumo, o desenvolvimento de medidas para a recomposição florestal e recuperação de mananciais tem sido promovidos na região pelo Comitê de Bacia dos Rios Piracicaba, Capivari e Jundiaí.

Pode-se afirmar que muitas das ações combinadas envolvendo o Comitê de Bacias e as prefeituras locais, entre elas a de Limeira têm auxiliado eficazmente na alteração do quadro de comprometimento dos recursos hídricos na região.

Deste modo, mesmo com a recente experiência em organização das representações e interesses sociais, que deriva também da recente abertura democrática e da instituição destes comitês, conforme observa Neder (2000, p.35), por meio da interferência destes comitês é que têm sido criados espaços possíveis para discussões e negociações referentes às políticas públicas inerentes ou interligadas a questão dos recursos hídricos.

Por sua vez, o fortalecimento destas instâncias de representação e o aumento da conscientização sobre os problemas ambientais relacionados aos recursos hídricos podem contribuir também para uma maior organização da sociedade civil no que diz respeito à cobrança da efetividade dos serviços prestados pelas empresas responsáveis pelos serviços de saneamento básico.

Finalmente, lembramos que os investimentos em redes de infra-estrutura não representam simplesmente ampliação de capital. O investimento em expansão das redes de infra-estrutura de saneamento básico e a ampliação do acesso a elas são capazes de transformar a vida de indivíduos e da sociedade, de modo a expandir consequentemente o acesso à cidadania. O não investimento representa retrocesso no caminho em direção à conquista da cidadania e ao risco de disseminação de doenças para toda a sociedade.

Deste modo, a análise da evolução dos serviços em Limeira e Manaus aponta que as concessões dos serviços à iniciativa privada não são a solução para o alcance da universalidade do atendimento das demandas e nem da qualidade dos serviços. 
Se por um lado o Estado, dentro da lógica da política neoliberal, considera a iniciativa privada como o meio para sua desoneração, do outro a iniciativa privada quer obter o máximo de lucro possível.

Ora, em um setor cujos investimentos necessários são altos e o retorno é de longo prazo, como no caso de saneamento básico, o lucro rápido só pode ser obtido a partir da combinação da cobrança de altas tarifas e dos fracos investimentos.

Pesados os aspectos de distinção entre cada uma das localidades abordadas (Manaus e Limeira), é possível afirmar que em ambos os casos o atraso nos investimentos esteve presente. Para o caso de Manaus, devido à concessão ser mais recente, o atraso nas metas contratuais previstas fica mais evidente, retratando uma situação de ausência de investimentos. Esta ausência de investimentos, aliada às altas tarifas impostas aos usuários indica que houve possibilidade de obtenção de lucro por parte da empresa.

Mas, como já foi abordado no capítulo anterior, além da possibilidade de lucro, a grande obtenção de rendimentos recai sobre a incorporação de capitais e sobre a capacidade de atração de investimentos individuais, por meio da imagem construída pelo grupo Suez S.A. Esta imagem, por sua vez, está amparada na idéia de controle de um bem escasso, ou seja, no poder de gestão sobre este bem, que neste caso é o da água.

A atuação da Águas de Limeira e Águas do Amazonas, portanto, possibilitam a reprodução ampliada do capital por meio do que Kowarick e Bonduki (1994, p.167) classificaram como mais-valia absoluta urbana, em que se cria um ciclo vicioso de exploração e de manutenção da condição de subcidadania, garantindo a reprodução do sistema e o atendimento dos interesses econômicos dominantes. 
CONSIDERAÇÕES FINAIS 
A evolução do conhecimento humano levou a constatação de que a água, no âmbito mundial, não está acessível a todos. As estatísticas apontam que a exclusão ao acesso só tende a crescer, acirrando conflitos no sentido do controle de sua exploração nos próximos anos.

À medida que os conflitos em torno da água se acirram e as demandas por este precioso líquido aumentam, tornam-se mais evidentes as preocupações acerca da gestão e do controle sobre o uso dos recursos hídricos.

Deste modo, a partir da segunda metade do século XX as preocupações com os problemas ambientais, dentre eles as questões sobre diminuição e comprometimento dos recursos hídricos têm trazido à tona a discussão do papel do Estado enquanto instância de gestão.

A Conferência das Nações Unidas para o Meio Ambiente e o Desenvolvimento, ocorrida no Rio de Janeiro em 1992, levantou o resgate de discussões, ainda que de forma genérica, sobre a necessidade de desenvolvimento de planos para a universalização do saneamento básico e recuperação dos mananciais, as quais foram inseridas na Agenda 21.

Os serviços de saneamento básico começaram então, a ser relacionados à questão da qualidade dos recursos hídricos de modo mais sistemático, aumentando a preocupação com as precárias redes de coleta e tratamento de esgotos.

Nota-se que é por meio dos serviços de saneamento básico que a maior parte das populações urbanas obtém água e, portanto, a gestão destes serviços possui importância estratégica, não só do ponto de vista ambiental, quanto à preservação da qualidade da água, mas também como instrumento de poder sobre o acesso à água.

Em 1997 ocorreu o primeiro Fórum Mundial da Água, em Marrakeshi, na Índia, o qual a ONU, apesar de declarar a água como um direito humano e um bem social e cultural, apresentou grande inclinação a apoiar a gestão privada dos recursos hídricos por meio dos serviços de saneamento básico. Este fato indica o fortalecimento da concepção da água como bem econômico.

Há duas correntes com formas distintas de conceber a gestão da água. A primeira defende a idéia de que devemos tratar a água como um bem comum. Segundo esta concepção a água é valorada como um bem essencial à reprodução da vida a qual todos têm o direito a acessar livremente. A universalidade e a economia de água, segundo esta concepção, podem ser obtidas de forma sistêmica, por meio da ampliação 
da conscientização sobre a necessidade do uso equilibrado e por meio da promoção dos esforços conjuntos dos diversos setores da sociedade.

A segunda corrente, apoiada por Agências Multilaterais como o Fundo Monetário Internacional - FMI e o Banco Mundial (Bird) defende que a água deve ser transformada em um bem econômico e como tal valorada. Para tanto, se pressupõe que o pagamento por ela e pelos serviços levaria à contenção do consumo e a viabilização de investimentos para melhoria e expansão dos serviços.

Baseando-se nesta última concepção as Agências Multilaterais investiram fortemente na disseminação de práticas capazes de estimular e facilitar o processo de privatização dos serviços relacionados à água, dentre eles o setor de saneamento básico.

A idéia de escassez de água passou, portanto, a ser incorporada pelos interesses econômicos como instrumento de pressão para a o fortalecimento da concepção da água como um recurso econômico, enquanto que aos poucos a concepção sistêmica de bem comum tem sido abandonada.

Entretanto, apesar da idéia de escassez ter contribuído para que a água fosse transformada em um recurso econômico e apropriada pela iniciativa privada por meio da obtenção da gestão dos serviços de saneamento básico, ela não é a única responsável pelo avanço das privatizações dos serviços de saneamento básico.

Além da idéia de escassez de água, o movimento de liberalização ocorrido no mercado financeiro, a partir de meados da década de 1980, como observado por Serfati (1998), com ampla possibilidade de intervenção de empresas no mercado monetário, possibilitou a ampliação do acesso ao mercado financeiro mundial e a ampliação da escala de acumulação pela via rentista.

Deste modo, no setor de saneamento básico os grandes grupos europeus, ao exemplo do grupo Suez S.A., se valeram da sua força de intervenção política e da sua capacidade de marketing para conquistar os mercados internacionais e ampliar seu capital, apoiando-se em transações financeiras que por sua vez, estabelecem suas bases financeiras nas fusões, incorporações e na atração de novos investidores.

Ao mesmo tempo em que os grandes grupos iniciaram o processo de expansão do seu poderio, os governos de Estados financeiramente dependentes estavam sendo pressionados a eliminar barreiras para a atuação destes grupos. Deste modo, as Agências Multilaterais em momentos de renegociação de dívidas passaram a intervir em favor destes grupos, exigindo, segundo Gomes (2003), a eliminação de restrições quantitativas ao comércio de serviços, a proibição da discriminação entre prestadores 
estrangeiros e domésticos, a eliminação de monopólios governamentais, entre outras coisas.

Estas condições permitiram a abertura da atuação de grandes grupos estrangeiros no setor de saneamento básico em vários países, entre eles o Brasil.

A escolha dos locais de atuação por parte dos grupos econômicos, respeita, entre outros aspectos, a possibilidade de articulação política entre as empresas do grupo e os governantes aliados, as possibilidades de obtenção de vantagens financeiras e de atração de novos investidores ao grupo.

Neste sentido, não é a vontade política no âmbito local isolada que atrai os grandes grupos, mas sim esta sinalização de abertura aliada à possibilidade de desenvolvimento das estratégias de reprodução do capital por parte do grupo, nesta determinada localidade.

Estas estratégias estão intensamente calcadas no setor financeiro. Deste modo, grande parte dos novos territórios conquistados pelos grupos para a sua atuação respeita os interesses financeiros, em pelo menos, um dos seguintes aspectos: possibilitam a captação de grandes financiamentos subsidiados por meio dos governos locais e do Banco Mundial, possibilitam a incorporação de novos capitais por meio das privatizações e possibilitam a atração de novos investidores no grupo devido ao controle sobre determinado recurso natural, ou seja, no caso específico, devido à conquista de monopólios importantes no que se refere à água.

Os serviços de saneamento básico, são como assume Silva (1999) monopólios naturais, já que pressupõe que o acesso à água ocorra por meio das empresas que gerem os serviços.

O mercado financeiro, por sua vez, é cada vez mais alimentado por especulação, fazendo com que a construção de símbolos de poder reflita sobre o preço das ações. Daí o interesse por áreas de grande ocorrência de água para a obtenção de novas concessões, como é o caso de Limeira e principalmente de Manaus.

Neste sentido, a ampliação do capital com a obtenção da concessão não se ampara somente na possibilidade de incorporação dos capitais já existentes, mas também na captura da imagem que estas localidades possuem perante o mercado financeiro, almejando-se a atração de novos investidores para as ações do grupo. O monopólio de pontos importantes no que concerne a possibilidade de exploração de água é uma mensagem implícita, utilizada na valorização das ações do grupo e, quanto a isto Manaus é reconhecida internacionalmente por se situar na Bacia Hidrográfica de 
maior ocorrência de água do Mundo o que facilita o processo de merchandising do grupo.

Orientados principalmente pela ampliação do capital pela via rentista, que visa o crescimento das ações no mercado de capitais, os grandes grupos econômicos, a exemplo do grupo Suez S.A., têm promovido uma dinâmica movimentação de capitais devido às fusões e incorporações de empresas. Esses grupos criam também uma complexa trama de interconexões entre as empresas que a eles estão ligadas e promovem grande centralização do poder e da gestão nos setores em que atuam, inclusive no setor de saneamento básico. Neste sentido, com a possibilidade de controle acionário de pequenas empresas por parte destes grandes grupos econômicos, aos poucos se perde a heterogeneidade de ação, de competitividade e de autonomia de decisão, já que estas empresas passam a se reportar ao controlador do grupo.

O grupo Suez S.A. disputa o mercado mundial relacionado ao setor de saneamento básico onde atuam poucos e grandes grupos, sendo o que mais tem se destacado em expansão das atividades em novos territórios no âmbito internacional. Este grupo também atua em outros setores e atividades, muitos dos quais interligados de alguma forma, como o setor de energia, o de tratamento de resíduos, de transportes, de telecomunicações, etc. o que permite a integração vertical dos fluxos de capitais entre empresas do grupo.

A complexidade e abrangência desta rede de conexões promovem também a ausência de controle sobre a atuação destes grupos. Deste modo, no âmbito local enquanto as restrições à participação de empresas estrangeiras são retiradas, as empresas coligadas aos grupos promovem sua integração eliminando, em cadeia, a concorrência em processos comerciais para consumo de matéria prima, prestação de consultorias, etc., ou seja, excluindo a participação de empresas que não façam parte do grupo, como foi possível notar para ambos os casos analisados.

Ainda, a dinâmica alteração de denominação, por parte do grupo e das empresas que o representam, é uma característica marcante entre estes grandes grupos econômicos, que também contribui para dificultar o reconhecimento de sua atuação no passado, bem como para compreender a sua abrangência de atuação no presente.

Tendo em vista que o grupo Suez S.A. obteve a concessão dos serviços de saneamento básico em Manaus-AM e Limeira-SP, procuramos analisar essas concessões e desvendar como estas integram as novas estratégias de negócios do grupo, avaliando sua lógica de atuação quanto à prestação dos serviços de saneamento básico. 
As duas concessões abordadas neste trabalho permitiram a atuação da iniciativa privada por pelo menos 30 anos, proporcionando a incorporação do capital da infraestrutura já oferecida por igual período.

As concessões dos serviços de saneamento básico em Limeira-SP e Manaus-AM foram obtidas por empresas do grupo Suez S.A., respectivamente em 1995 e em 2000, integrando as pressões das políticas neoliberais que induziram as privatizações neste período.

A concessão dos serviços à iniciativa privada nestes dois municípios foi conseqüência, em parte, da desestruturação do setor de saneamento básico que se apoiou, entre a década de 70 e 80, no Plano Nacional de Saneamento - PLANASA o qual foi abandonado, principalmente devido a sua incapacidade de equilíbrio econômico.

Nota-se que o período entre a década de 70 e 80 foi marcado por muitas transformações do setor, que apresentou em um primeiro momento uma centralização dos serviços pelas companhias estaduais e depois a retomada de algumas concessões por parte das instâncias municipais.

Contudo a atuação municipal não durou muito, já que na década de 1990, as novas políticas impostas ao setor de saneamento não viriam a estimular a continuidade da prestação dos serviços por empresas públicas, especialmente por parte de empresas municipais, já que a possibilidade de financiamento foi bloqueada com o intuito de induzir a privatização do setor.

Segundo Britto (2001) o bloqueio da possibilidade de financiamento por parte de instâncias públicas faziam parte de um pacote de medidas que deveriam reduzir os gastos públicos, impostas pelo Fundo Monetário Internacional no período da renegociação do pagamento da dívida externa.

Deste modo, é possível notar que a entrada dos grandes grupos econômicos transnacionais ocorre já neste mesmo período, aproveitando a abertura proporcionada pelas Agências Multilaterais e pela fragilidade do Estado nacional.

Além da posição geográfica privilegiada do município, inserido na Bacia do Paraná e nas proximidades da área de afloramento do Aqüífero Guarani, a concessão de dos serviços de saneamento básico em Limeira também contemplou a aquisição dos serviços sem a necessidade de ônus para o grupo Suez S.A., o que significou maiores vantagens financeiras para o grupo. 
No que concerne ao alinhamento político entre o grupo Suez S.A. e o governo municipal, pode-se afirmar que a opção pela concessão ultrapassou a questão econômica no que tange a viabilidade de financiamento dos investimentos no setor.

Como as soluções econômicas para o desenvolvimento dos serviços estavam sendo encaminhadas com sucesso, como observado por Justo (2004), pode-se afirmar que a opção pela concessão dos serviços à iniciativa privada foi mais política do que econômica.

Este contexto deixa transparecer que para o caso de Limeira, apesar de também contar a privilegiada posição geográfica, esta passa a ser secundária frente à possibilidade de vantagens econômicas e políticas, com o processo de incorporação de capitais sem ônus e ampla conivência política do governo municipal.

Até certo ponto o caso de Manaus é diferente, sendo que a posição geográfica ficou marcada como principal atrativo.

Os altos volumes de investimentos necessários ao desenvolvimento dos serviços em Manaus, o baixo poder aquisitivo de grande parte da população aliado ao fato da concessão ter sido onerosa, com desembolso de $\mathrm{R}$ \$193 milhões para a aquisição de ações da Manaus Saneamento por parte do grupo, indicam forte interesse na obtenção da concessão dos serviços nesta cidade. Assim, a possibilidade de obtenção deste ponto estratégico do ponto de vista de ocorrência de água, certamente supera a potencialidade de obtenção de lucro no âmbito local.

É fundamental que se compreenda que a entrada deste grupo transnacional nestas duas localidades brasileiras está calcada na possibilidade de obtenção de rendimentos, por meio da incorporação de capitais, que no caso das concessões são os bens imobilizados, resultados de investimentos por parte da iniciativa pública e, também, na atração de novos investidores, por meio do fortalecimento da imagem de poder frente à gestão dos serviços ligados a água.

A análise das concessões, por meio da avaliação do desempenho das empresas Águas de Limeira e Águas do Amazonas, quanto aos investimentos em serviços de saneamento básico, apontou que a prioridade do grupo está voltada, especialmente para a obtenção de rendimentos, corroborando a hipótese levantada.

O endividamento contínuo das empresas, conforme foi discutido no segundo e no terceiro capítulo, não está diretamente relacionado às despesas de operação, que em geral são mais baixas do que as receitas totais obtidas na prestação dos serviços, mas ao pagamento de juros e de valores para amortização de dívidas. Segundo os balanços 
patrimoniais das empresas em questão, as transações comerciais e de serviços, como compra de insumos, prestação de consultorias, etc., em grande parte envolvem contração de dívidas com empresas ligadas ao grupo Suez. A manutenção de alto endividamento e dependência de outras empresas do grupo, com as quais se mantém um constante fluxo de caixa, indica a estratégia do grupo para viabilização de rendimento financeiro.

É importante lembrar que este endividamento, além de atravancar os investimentos em ampliação e melhoria dos serviços também possibilita, por meio do Projeto de Lei 7361/06, sancionado no mês de janeiro de 2007 pelo Presidente da República, a obtenção de altas indenizações em caso de rescisão de contrato. Segundo a Lei os valores não amortizados de investimentos já efetuados pela empresa deveriam ser pagos pela instância concedente, ou seja, pelo Estado.

Ainda, segundo a mesma Lei estes valores passaram a ser relacionados também às dívidas e transações financeiras pendentes da empresa concessionária, o que pela lógica eleva o valor a ser amortizado em caso de rescisão, sendo ainda mais vantajoso para o grupo. Deste modo, o endividamento da empresa por meio de transações com outras empresas do grupo passa a ser interessante, à medida que mesmo perdendo em curto prazo, em caso de rescisão ou no final da concessão os valores acumulados serão assumidos pelo Estado.

Como lembra Capel (2000) também a falta de transparência sobre os reais custos de operação dos serviços e as operações de engenharia financeira envolvendo compra e venda de ações, por parte das empresas privadas prestadoras de serviços de saneamento básico tem proporcionado a obtenção de altos lucros, os quais não são aplicados na melhoria do setor.

Deste modo, é possível notar que a prioridade na atuação das empresas é o de viabilização do capital financeiro do grupo, por meio de diversas estratégias.

Quanto à prestação dos serviços é importante notar que há diferenças na atuação das duas empresas, já que as condições de desenvolvimento dos serviços também eram bastante diversas nas duas situações.

A concessão em Limeira foi marcada por condições favoráveis quanto ao grau de desenvolvimento econômico municipal, quanto ao desenvolvimento das políticas públicas que permitiram o avanço dos índices de cobertura dos serviços, quanto ao desenvolvimento prévio das infra-estruturas e da cobertura incorporada pela empresa e mesmo quanto à capacidade de pagamento da população. Neste sentido, enquanto o 
crescimento planejado da ocupação urbana em Limeira, bem como o padrão de renda elevado contribuiu para beneficiar a empresa no cumprimento das metas previstas em contrato, em Manaus a desarticulação entre as políticas urbanas e as de saneamento, bem como a incapacidade de pagamento de grande parte da população contribuíram para o não cumprimento das metas.

Sob o aspecto da regulação, observam-se nos dois casos problemas quanto à autonomia dos órgãos responsáveis, já que no caso de Limeira o SAAE é mantido com recursos advindos da empresa e em Manaus a falta de recursos financeiros compromete a capacidade técnica de avaliação do desenvolvimento dos serviços. Isto aumenta os riscos de captura do regulador pelo regulado, como já havia sido alertado por Vargas e Lima (2004).

A captura do regulador pelo regulado ocorreu em diversas situações, devendo ser destacado o caso de Manaus. Entre elas a falta de capacidade técnica para apuração e cobrança do desenvolvimento dos serviços, a aceitação de revisões tarifárias que comprometiam o orçamento de grande parte da população, a aceitação de quebra das metas contratuais e até a aceitação da revisão de grande parte da estrutura contratual prevista, acirrando ainda mais a defesa dos interesses privados em detrimento dos públicos.

Neste último caso, é importante lembrar a revisão requisitada pela empresa Águas do Amazonas à ARSAM em 2005, na qual a empresa assumia o não cumprimento das metas e solicitava a aplicação de alternativas para que se viabilizassem os investimentos necessários no futuro.

A primeira alternativa apresentada dizia respeito à possibilidade de revisão tarifária, mesmo sendo esta uma das mais altas no Brasil.

A segunda alternativa apresentada pela empresa coloca em cheque a própria concessão como opção econômica de desoneração do Estado, já que propunha o comparecimento do Estado com fornecimento de subsídios constantes para a viabilização dos investimentos necessários.

É importante compreender que o processo de negociação das alterações contratuais e das metas ocorreu um ano antes de ser cobrado o cumprimento das metas contratuais, com prazo para o ano 2006. Deste modo, o que se observa é que seis anos após a concessão o não cumprimento das mesmas passou a ocupar lugar secundário, sendo substituído pela discussão de qual opção se tomar para auxiliar a iniciativa privada a alcançar o equilíbrio financeiro. Mais uma vez nota-se a socialização dos 
prejuízos por meio da transferência do ônus para o Estado, enquanto que no âmbito internacional as ações da bolsa de valores do grupo Suez S.A., apresentam crescimento constante.

O sucesso do grupo, portanto, não corresponde necessariamente ao sucesso das atividades das empresas a ele ligadas. Estas empresas orientadas por uma política comum servem a um "interesse financeiro predominante" 60 , conforme exposto por Anaya (1990), integrando o ciclo de capitais centralizados por meio de uma holding do grupo.

Estas características, no entanto, são esquecidas quando o Estado trata "como iguais, capitais que são desiguais» ${ }^{61}$, resultando na produção e fortalecimento da desigualdade como observado por Fiori (1995).

Deste modo, ao contribuir para o almejado equilíbrio financeiro destas empresas no âmbito local, o Estado na realidade afirma o poder deste grupo e aprova suas estratégias de reprodução do capital bem como se mostra frágil no momento da cobrança de resultados em prol da melhoria dos serviços.

Em relação a estes fatos não foram notados movimentos relevantes no que concerne à participação efetiva da sociedade civil nos processos decisórios ou mesmo na cobrança de seus direitos. Com exceção da ação civil pública do Ministério Público movida em Limeira para apuração de corrupção e da ação civil pública do Ministério Público em Manaus para cobrança dos parâmetros mínimos de qualidade dos efluentes lançados nos cursos d'água, em respeito à legislação federal, não houve manifestação organizada da sociedade civil.

Apesar do descontentamento da população entrevistada, demonstrado na pesquisa de campo, especialmente para o caso de Manaus, quanto ao custo das tarifas, à qualidade da água, à falta de cobertura de esgoto e principalmente quanto à intermitência do abastecimento, as resistências não ocorrem de forma organizada, o que tem permitido a desconsideração destas forças no momento de tomada de decisões.

As resistências quanto ao pagamento por serviços ainda precários, especialmente no caso de Manaus, se dão de forma isolada, com o aumento da perfuração de poços de forma irregular, com o aumento das ligações clandestinas à rede ou mesmo por meio do aumento da inadimplência.

\footnotetext{
${ }^{60}$ ANAYA, Eduardo. Los grupos de poder econômico. Un análises de la oligarquia financeira. LimaPeru: Editorial Horizonte, 1990.

${ }^{61}$ FIORI, José Luis. Em busca do dissenso perdido. Ensaios Críticos sobre a festejada crise do Estado. Rio de Janeiro: Insight, 1995.
} 
Deste modo, ao mesmo tempo em que estas estratégias por parte dos usuários insatisfeitos representam a resistência aos serviços precários oferecidos pela empresa Águas do Amazonas, estas também são argumentos para o não investimento por parte da empresa, já que implicam em diminuição da arrecadação e em maiores custos com fiscalização e manutenção das redes, encerrando um ciclo vicioso.

No que se refere à questão do consumo, há grande lacuna quanto aos investimentos em conscientização sobre o uso equilibrado da água, sendo que no caso de Limeira se apresentou altos índices de consumo de água per capta e no caso de Manaus grandes volumes de perda de água na distribuição. A falta de estímulo à economia de água, portanto, vai ao encontro dos interesses privados, à medida que propicia o lucro, seja por meio de obtenção de maiores receitas devido aos maiores volumes consumidos, ou de tarifas mais altas para cobrir as perdas de água tratada.

É possível concluir que a atuação privada construída com base na concepção da água enquanto recurso econômico priorizou a ampliação do capital em detrimento do alcance do equilíbrio em seu consumo e da universalização do seu acesso. Deste modo, o poder de pagamento dita o consumo, bem como induz o desenvolvimento dos investimentos em áreas mais ricas em detrimento de áreas mais pobres.

Mais uma vez se faz necessária a participação do Estado, por meio do repasse de recursos financeiros aos Comitês de Bacias, na promoção de trabalhos no sentido da recuperação e ampliação da conscientização ambiental. São estas ações conjuntas, com a participação de vários setores públicos e de representações da sociedade que têm contribuído efetivamente com a recuperação ambiental. Isso se dá frente a um quadro em que os investimentos em campanhas educativas que contribuam para a ampliação de uma cultura de economia de água têm sido negligenciados por parte das empresas.

Também é possível vislumbrar a contribuição destas ações conjuntas entre os comitês e as municipalidades também na cobrança do desenvolvimento dos serviços relacionados à água, em especial os serviços de saneamento básico, já que os mesmos estão estreitamente relacionados à saúde, a qualidade da água, ao desenvolvimento econômico local e, portanto, à promoção da cidadania. Neste sentido, o município de Limeira foi mais beneficiado do que o de Manaus, já que as práticas de ação dos comitês de Bacia no Estado de São Paulo, em especial do comitê da Bacia Hidrográfica dos rios Piracicaba, Capivari e Jundiaí estão mais desenvolvidas do que os comitês do Estado do Amazonas. 
Cada vez que o Estado se mostra necessário no preenchimento de lacunas deixadas pela iniciativa privada, maiores se mostram as contradições das políticas neoliberais apregoadas, já que segundo as mesmas a atuação do Estado deveria ser mínima.

A necessidade do Estado na regulação, na educação, nas políticas urbanas e no subsídio dos investimentos necessários, leva ao questionamento sobre a necessidade da presença da iniciativa privada na prestação dos serviços essenciais.

No âmbito local a empresa Águas de Limeira não só capturou investimentos passados no momento da concessão, como também se beneficiou da forte presença do Estado em desenvolvimento econômico e urbano.

A empresa Águas do Amazonas não obteve a mesma sorte. A decadência econômica, a desarticulação das políticas urbanas e o acúmulo dos déficits de investimentos passados por parte do Estado, resultaram em entraves aos avanços por parte da empresa, motivo pelo qual solicitou subsídios do Estado.

Contudo, não se pode esperar que a empresa seja somente a vítima de uma situação insolúvel, já que ela integra o capital e as estratégias de acumulação de um grande grupo econômico, o Suez S.A., que não tem contribuído eficazmente para a sustentação do setor já que tem priorizado os investimentos financeiros em detrimento dos produtivos.

Uma vez que a gestão dos serviços após a concessão é responsabilidade da iniciativa privada, o papel do Estado para a viabilidade dos serviços está relacionado à promoção do crescimento econômico, do planejamento urbano e da regularização urbana bem como à execução de obras que possibilitem a efetivação das políticas públicas urbanas e à educação. Contudo, para tanto há necessidade de investimentos públicos.

A adoção da concepção da água como recurso econômico, e o direcionamento dos financiamentos ao setor de saneamento básico somente por intermédio da iniciativa privada contribuiu para um enfraquecimento ainda maior das instâncias públicas e para a negligência do caráter sistêmico que envolve o planejamento de expansão dos serviços e sua operação, que deveria estar articulado também com outros setores de atividades, como o setor de saúde e o de meio ambiente. Esta falta de articulação, como pudemos discutir no terceiro capítulo, gerou entraves, como ocupação irregular e criação de vazios urbanos, encarecendo a extensão e a manutenção da infra-estrutura, a falta de 
investimentos em coleta e tratamento de esgotos, gerando problemas de saúde pública, etc.

É interessante notar que as mesmas políticas que bloquearam a capacidade de financiamento das instâncias públicas, para permitir a entrada dos grandes grupos econômicos no Brasil, hoje atravancam também o avanço do desenvolvimento das empresas destes grupos no âmbito local.

As opções políticas e econômicas neoliberais privilegiaram, portanto, o desenvolvimento financeiro dos grupos em detrimento do atendimento das demandas locais e, a continuidade de aplicação deste paradigma implica em fortalecimento da dependência do Estado, em enfraquecimento de sua capacidade de intervenção, e em continuidade da exclusão da população mais empobrecida de seus direitos sociais.

Finalmente, é possível notar que a transferência dos serviços à iniciativa privada, esteve pautada pela idéia de que esta solucionaria os problemas financeiros com a aplicação de capitais privados. Contudo, o comprometimento destes capitais com formas mais rentáveis de reprodução resultaram na retração dos investimentos e na ampliação dos déficits na qual o Estado foi novamente chamado a participar com a permissão de repasse de aumentos à população local ou mesmo, no caso de Manaus com subsídios.

Ainda, como compete ao Estado articular políticas de desenvolvimento, os serviços de saneamento básico sob responsabilidade da iniciativa privada, passam também a depender dele, como pudemos observar para ambas as localidades analisadas. Portanto, a perda de poder do Estado e sua fragilização repercutem dialeticamente no insucesso do setor de saneamento básico, difundindo conseqüências negativas para toda a sociedade.

Por sua vez, a imagem da concessão não contempla o desempenho da empresa no âmbito local, deste modo, no âmbito internacional a importância da concessão continua praticamente imutável desde a sua incorporação ao grupo, já que não se divulgam os insucessos e ainda menos os riscos destes insucessos, no que diz respeito ao comprometimento ambiental e da saúde pública.

Neste sentido, enquanto no âmbito local as empresas apresentam grandes dificuldades para a prestação dos serviços, no âmbito internacional o grupo ao qual pertencem estas empresas apresenta movimento de crescimento em suas ações.

Este movimento encerra uma cilada no que concerne a sua capacidade de autosustentação, já que mostra fragilidades que despontam no âmbito local, como a 
explosão da insatisfação social, de conflitos e mesmo de epidemias, que têm sido motivo de rescisão de contratos em vários países.

Deste modo, ao mesmo tempo em que é no âmbito local que as conseqüências da ausência de investimentos no setor de saneamento são sentidas, também é no âmbito local que as possibilidades de resistência e de alteração das políticas são possíveis.

O Estado, portanto, deve ser capaz de reconhecer as reivindicações nesta escala, de modo que se passe a atender aos interesses sociais em detrimento dos privados e não o oposto, como tem ocorrido. 


\section{REFERÊNCIAS}


AGÊNCIA CÂMARA. Audiência vai discutir contaminação de poços artesianos. 22/09/2005. Disponível em: < http://www.camara.gov.br/internet/agencia/materias.asp?pk=75296 $>$ Acesso em 10/10/2005.

ÁGUAS DO AMAZONAS. Números e Indicadores de dez/2006. Disponível em: < http://www.aguasdoamazonas.com.br/empresa.php?.nomeArquivo=numeros\&indiceMenuSelecionado=in

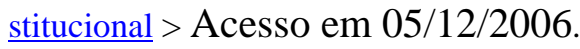

ANAYA, Eduardo. Los grupos de poder econômico. Un análises de la oligarquia financeira. Lima-Peru: Editorial Horizonte, 1990.

ANDRADE, Manuel Correia. O Desafio Ecológico - Utopia e Realidade, São Paulo: Hucitec, 1994.

ARROYO, Mônica. São Paulo e os fluxos internacionais de mercadorias. In: CARLOS, A.F.A. e OLIVEIRA, A.U.de. (Orgs.) Geografias de São Paulo. A metrópole do século XXI. São Paulo: Contexto, 2004. p.85-103.

AZEVEDO, Sérgio de; GUIA, Virgínia R.dos. M. Governança Metropolitana e Reforma do Estado. O caso de Belo Horizonte. In: Revista Brasileira de Estudos Urbanos e Regionais. $n^{\circ}$ 3. outubro, 2000.

BANCO NACIONAL DE DESENVOLVIMENTO ECONÔMICO E SOCIAL. BNDES financia expansão da rede de água e esgoto de Manaus. 03/01/03. Disponível em: < http://www.bndes.gov.br/noticias/not574.asp > Acesso em 26/03/03.

BAU, João. Globalização da Economia e o Abastecimento de Água: contribuição para o debate para o futuro do setor público. In: SANTOS Jr., BRITTO e PORTO (Orgs.). Políticas de Saneamento Ambiental: Inovações na Perspectiva do Controle Social. Rio de Janeiro: IPPUR/UFRJ/FASE, 1998.

BECHT, J. Edwin, BELZUNG, L.D. World resource management. Key to civilization and social achievement, Prentice Hall Inc. New Jersey, Englewood Cliffs, 1975.p.22.

BECKER, Bertha. Modelos e cenários para a Amazônia: o papel da ciência. Revisão das políticas de ocupação da Amazônia: é possível identificar modelos para projetar cenários? Parcerias e Estratégias. Rio de Janeiro: IPPUR n.12, p.135-159, Setembro 2001. 
A (Des) ordem global, o desenvolvimento sustentável e a Amazônia. In: BECKER, B.K. et al. (Orgs.) Geografia e Meio Ambiente no Brasil. São Paulo: Hucitec/Annablume, 2002.

DI BERNARDO, L. DANTAS, A.Di Bernardo. Métodos e técnicas de tratamento da água. $2^{\mathrm{a}}$ edição, São Carlos: RiMa, 2005.

BISHOP, M. \& KAY, J. Does Privatization Work? London: Centre for Business Strategy. London Business School,1988.

BRANCO, Samuel Murgel. Usos múltiplos I: conservação de represas e abastecimento de água potável. (1981)

BRASIL. Constituição da República Federativa do Brasil. Capítulo VI, Artigo 225. 1988.

BRITTO, Ana Lúcia. Experiências Internacionais na Gestão de Serviços de Saneamento: os casos da Inglaterra, da França e da Argentina. In: SANTOS Jr., BRITTO e PORTO (Orgs.). Políticas de Saneamento Ambiental: Inovações na Perspectiva do Controle Social. Rio de Janeiro: IPPUR/UFRJ/FASE, 1998.

BRITTO, A.L. A regulação dos serviços de saneamento básico no Brasil: Perspectiva histórica, contexto atual e novas exigências de uma regulação pública. In: Anais do $I X$ Encontro Nacional da ANPUR - Ética, Planejamento e Construção Democrática do Espaço. Rio de Janeiro: IPPUR, 2001.

CANO, Wilson. Perspectiva do desenvolvimento econômico do interior paulista. In: TARTAGLIA, J.C. \& OLIVEIRA, O.L.de (Orgs.) Modernização e desenvolvimento no interior de São Paulo. São Paulo: Unesp, 1988.

CAPEL, Horácio. El água como servicio público. A propósito del Seminário Internacional Faire parler lês réseaux. Revista Bibliográfica de Geografia e Ciências Sociales. Universidad de Barcelona n.218, 22/03/2000. Disponível em: < http: www.ub.es/geocrit/b3w-218.htm > Acesso em 14/03/2005.

CARIDE, D. Legislação ignora exploração subterrânea. In: Jornal Gazeta Mercantil, São Paulo, 19 de novembro de 1998, p.6.

CASTRO, José Esteban. El control social del água y la formación de los derechos de ciudadanía em México: Una perspectiva de largo plazo. In: Actas del II Congresso Europeu de Latinoamericanistas. América Latina: cruce de culturas y sociedades. La 
dimensión histórica y la globalización futura. Halle - Alemanha: Thomas Bremer Y Susanne Schütz, 1999.

CHESNAIS, François. A mundialização do capital. Trad. Silvana Finzi Foá. São Paulo: Xamã, 1996. Título original: La mondialisation du capital (Paris, Syros, 1994).

CLARIN. Por mal servicio, Suez fue echada de Atlanta, EE.UU.28/09/2005. Disponível em: < http://www.servicios.clarin.com/notas/jsp/v7/notas/imprimir.jsp?pagid=1060842 > Acesso em 08/10/2005.

CLARKE, Robin e KING, Jannet. O Atlas da Água. SãoPaulo: Publifolha, 2005.

CONSÓRCIO INTERNACIONAL DE INVESTIGAÇÃO JORNALÍSTICA. Water and power: the french connection, 2003. Disponível em: < http://www.icij.org/datweb/water/PrintReady.aspx?AID=4 > Acesso em 04/06/03.

. Cólera and the Age of the water barons, 2003. Disponível em: < http://www.icij.org/datweb/water/PrintReady.aspx?AID=1 > Acesso em 04/06/03.

DAHLMAN, Carl e FRISCHTAK. Tendências da Indústria Mundial. Brasília: Fórum Nacional da Indústria, 2005.

DI PIETRO, Maria Sylvia Zanella. Do direito privado na administração pública. São Paulo: Atlas, 1989, p.94.

DIÁRIO DE CUIABÁ. Ediçção n.9946 de 10/05/2001. Disponível em: < http://www.diariodecuiabá.com.br/detalhe.php?cod=51426. > Acesso em: 11/05/2001.

FABRIANI, C.B.; PEREIRA, V.M. Tendências e Divergências sobre o Modelo de Intervenção Pública no Saneamento Básico. Texto para Discussão n.124.. Rio de Janeiro: UFRJ/IEI, 1987.

FAO. Food and Agriculture Organization. Aquastat. Disponível em: < http://www.fao.org/ag/agl/aglw/aquastat/ > Acesso em abril/2005.

FAPESP. Perigo na beira do rio. Agência de Notícias da Fundação de Amparo à Pesquisa do Estado de São Paulo, 01/06/2005. Disponível em < http://www.fapesp.br/agencia/boletim_print.php?data[id_materia_boletim\} $=3787>$ Acesso em 01/06/05.

FAPESP. Água, riqueza em exame. O maior reservatório de água da América do Sul pode ter excesso de radioatividade. Revista Pesquisa FAPESP. Março, 2001. Disponível 
em: < http://www.revistapesquisa.fapesp.br/?art=1215\&bd=1\&pg=1\&1g= > Acesso em março, 2001.

FIORI, José Luis. Em busca do dissenso perdido. Ensaios críticos sobre a festejada crise do Estado. Rio de Janeiro: Insight, 1995.

GAZETA MERCANTIL. A disputa pelo lucrativo negócio da água. 06/02/2002.

Pioneirismo em saneamento implanta vitrines pelo país afora. São Paulo, 09 de outubro de 2002.

GENTILI, Rafael. Kirchner reestatiza água da Argentina. Trad. Naila Freitas In: Agência Carta maior, 04 de abril de 2006.

GLEICK, PETER H. Basic water requirements for human activities: Meeting basic needs. In: Water International, vol.21, n. ${ }^{\circ}$ 2. Oakland-CA, EUA: IWRA, 1996. p.83-92

GOMES, Marcel. Água não é mercadoria. In: Agência Carta Maior. Disponível em : < http://www.planetaportoalegre.net/publique/cgi// > Acesso em 03/04/2003.

GOUVELLO, Bernard de. Gestão dos serviços de abastecimento d’água e esgotamento sanitário: o modelo francês e sua exportabilidade. In: SANTOS JR, O. A; PORTO, H.R.L. e BRITTO, A.L. (Orgs.) Políticas de saneamento ambiental: inovações na perspectiva do controle social. Rio de Janeiro: FASE, 1998.

GUEDES, Ana Lúcia. Repensando a nacionalidade das empresas transnacionais. In: Revista de Sociologia e Política n.14, p.51-60, jun. 2000.

GRAMSCI, Antonio. Obras Escolhidas. Vol.1, Lisboa: Editorial Estampa, 1974.

GRANZIERA, Maria Luiza Machado. Direito de Águas. Disciplina Jurídica das Águas doces. São Paulo: Atlas, 2001.

GUTTMANN, Robert. As mutações do capital financeiro. In: CHESNAIS, F. (Coord.) A mundialização financeira: gênese, custos e riscos. São Paulo: Xamã, 1998.

HIRATA, Ricardo. Contaminacion del água subterrânea: mejor prevenir que remediar. São José: EUNED, 2002.

JACOBI, Pedro Roberto. Educação, ampliação da cidadania e participação. São Paulo: Educação e Pesquisa. Vol.26. n²2, Jul/Dez. de 2000. 
JUSTO, Manoel C.D.de M. Financiamento do Saneamento Básico no Brasil - Uma análise comparativa da Gestão Pública e Privada. Dissertação de Mestrado, Campinas: Unicamp/Instituto de Economia, 2004.

KOWARICK, Lúcio e BONDUKI, Nabil. Espaço urbano e espaço político: do populismo à redemocratização. In: KOWARICK, L. (Org.) As lutas sociais e a cidade. São Paulo passado e presente. Rio de Janeiro: Paz e Terra, 1994.p.147-177.

KUNZ, Airton et al. Novas tendências no tratamento de efluentes têxteis. São Paulo: Química Nova, V.25, n.1, 2002.

LAUBER, Patrícia. Seeing earth from space. New York: Orchard Books, 1990.

LENCIONI, Sandra. Reestruturação urbano-industrial no Estado de São Paulo: a região da metrópole desconcentrada. In: Revista Espaço \& Debates n.38, 1994, p.54-61.

- Uma nova determinação do urbano: O desenvolvimento do processo de metropolização do espaço. In: LEMOS, A.I.G. \& Carlos, A.F.A.(Orgs.) Dilemas urbanos. Novas abordagens sobre a cidade. $1^{\text {a }}$ Edição. São Paulo: Contexto, 2003. p.35-44.

LOFTUS, Alex. Reification and the dictatorship of the water meter. Antípode, Vol. 38, 5, p. 1023 nov.2006.

MACHADO, José Luiz. A redescoberta do Aqüífero Guarani. In: Revista Scientific American Brasil. Edição n.47. Abril, 2006.

MARQUES, José Augusto Veiga da Costa. Análise Financeira das Empresas. Liquidez, retorno e criação de valor. Rio de Janeiro: Editora UFRJ, 2004.

MARTINS, Rodrigo Constante. A construção social do valor econômico da água: Estudo sociológico sobre agricultura, ruralidade e valoração ambiental no estado de São Paulo. Tese de doutorado, Escola de Engenharia de São Carlos - USP, 2004.

MARX, Karl (1818-1883). O Capital: Crítica da Economia Política. Apresentação de Jacob Gorender. SINGER, P.(coordenaçãoe revisão). Tradução de Regis Barbosa e Flávio R. Kothe. São Paulo: Abril Cultural, 1985.

MEIRELLES, H.L. Direito Administrativo Brasileiro. 20ª ed. São Paulo: Saraiva, 1994. NEDER, R.T. Avaliação da capacidade governativa de Comitê de Bacia Hidrográfica Metropolitana. São Paulo: FAPESP, julho, 2000. 
OLIVEIRA, Cheila Santos de. et.al. Avaliação da influência do estado de conservação de reservatórios da rede de distribuição sobre a potabilidade da água distribuída em Manaus no período de 2000 a 2001. In: III Congresso brasileiro de regulação de serviços públicos concedidos. Gramado - RS: Associação Brasileira de Agências de Regulação, maio de 2003.

OMS - Organização Mundial da Saúde. Regional and global drinking water and sanitation coverage estimates. 2002. disponível em: < http://www.who.int/water_sanitation_health/monitoring/jmp2005.annexes.pdf $>$ Acesso em jan/2006.

ORGANIZAÇÃO PARA COOPERAÇÃO ECONÔMICA E DESENVOLVIMENTO OCDE. Household Water Pricing in OECD Countries, Paris- Fr: OCDE - Publishing, Maio, 1999.

PEIXOTO, João Batista. Aspectos Jurídicos - Institucionais na Gestão dos Serviços de Saneamento Ambiental. In: SANTOS Jr, BRITO e PORTO (Orgs.) Políticas de Saneamento Ambiental: Inovações na Perspectiva do Controle Social. Rio de Janeiro: IPPUR/UFRJ/FASE, 1998.

PINSKY, Jaime. Introdução. In: PINSKY, J.; PINSKY, Carla Bassanezi (Orgs.). História da Cidadania. São Paulo: Editora Contexto, 2003.

POCHMANN, Marcio. O emprego na globalização. São Paulo: Editora Boitempo, 2001.

RAFFESTIN, Claude. Por uma geografia do poder. Tradução Maria Cecília França, Série Temas vol.29 Geografia e política, São Paulo: Ática, 1993.

REBOUÇAS, Aldo.Uso inteligente da água. São Paulo: Escrituras Editora, 2004.

Água Doce no Mundo e no Brasil. In: REBOUÇAS, A.C.; BRAGA, B. e TUNDISI, J.G. (Orgs) Águas Doces no Brasil. Capital Ecológico, Uso e Conservação. São Paulo: Escrituras, 1999.

RENNER, Michael. Nacional Security: The Economic and Environmental Dimensions, 1989.

RIBEIRO, Helena. Geografia para a saúde nas cidades e a questão da escala. In: Anais do X Encontro de Geógrafos da América Latina. Por uma Geografia Latino- 
Americana: Do labirinto da solidão ao espaço da solidariedade. de 20 a 25 de março de 2005.

RIBEIRO, Wagner Costa. A ordem ambiental internacional. São Paulo: Contexto, 2001.

ROCHA, Aristides Almeida. Fatos Históricos do Saneamento. São Paulo: Scortecci, 1997.

SANCHEZ, Oscar Adolfo. A privatização do Saneamento. São Paulo: São Paulo em Perspectiva, 15(1), 2001. Disponível em: < http://www.scielo.br/pdf/spp/v15n1/8593.pdf > Acesso em 15/08/05.

SANCHEZ, Inaiê. Para entender a internacionalização da economia. São Paulo: Editora Senac, 1999.

SANTANA, L. Preço da água é um dos pivôs da crise. Jornal O Estado de São Paulo. Internacional. A11. 9/03/2005.

SÃO PAULO (Estado). Comitê de Bacias Hidrográficas do Rio Piracicaba, Capivari e Jundiaí. Disponível em: http://www.comitepcj.sp.gov.br/Fehidro/PCJ-Geral-Tomador.asp > Acesso em out/2006.

SEADE. Fundação Sistema Estadual de Análise de Dados do Estado de São Paulo. Pesquisa de condição de vida no Estado de São Paulo. Disponível em: < http://www.seade.gov.br/cgi-bin/pcrv98/opcao_pcv_01.ksh?ano=1998 > Acesso em 08/08/2006.

SERFATI, Claude. O papel ativo dos grupos predominantemente industriais na financeirização da economia. In: CHESNAIS, F. A mundialização financeira. São Paulo: Xamã, 1998. p.141-180.

SILVA, Márcio Luiz. Características das águas subterrâneas numa faixa norte-sul na cidade de Manaus - AM. In: Revista Escola de Minas v. 54, n.2, Ouro Preto, 2001.

SILVA, Ricardo Toledo. A regulação e o controle público da infra-estrutura e dos serviços urbanos no Brasil. In: DEAK, C. \& SCHIFFER, S. O processo de urbanização no Brasil, São Paulo: FUPAM/Edusp, 1999.

SILVA, R.T.; BRITO, A.L. Cooperação Brasil-França em Saneamento Ambiental. Conferência Bilateral Cidade, Ciência e Tecnologia: Cooperação Brasil-França. Comunicação apresentada. Rio de Janeiro, 20 a 23 de maio de 2002. 
SINGER, Paul. Direitos Sociais. A cidadania para todos. In: PINSKY, J.; PINSKY, C.B. (Orgs.) História da Cidadania. São Paulo: Editora Contexto, 2003.

SODRÉ, Nelson Werneck. A Farsa do Neoliberalismo. Rio de Janeiro: Graphia Editorial, 6a edição, 1999.

SOUZA, Paulo Henrique. Insegurança espanta capital estrangeiro. Disponível em meio eletrônico, no Jornal da ABDIB. Disponível em: < http://www.abdib.org.br/noticias_lista_ultimas.cfm?id_noticia=1349 $>$ Acesso em 23/09/2005.

SWANN, D. The retreat of the State. Deregulation and privatization in the UK and US. Hertfordshire: Harvester-Wheatsheaf, 1988.

TABB, Willian K. Globalization is an Issue, the power of capital is the issue. In: Globalization - Monthly Review, June 1997.

TUNDISI, José Galisia. Água no século XXI. Enfrentando a escassez. São Carlos: RimMa/IIE, 2003.

UNCTAD - World Investment Report 2004: The shift toward Services. Disponível em: $<$ www.unctad.org/en/docs/wir2004ch3_en.pdf $>$ Acesso em agosto/2005.

VARGAS, Marcelo Coutinho e LIMA, Roberval Francisco. Concessões privadas de saneamento no Brasil: Bom negócio para quem? In: Ambiente \& Sociedade - Vol. VII n.2, jul.-dez. de 2004.

VIVEIROS, M. Esgoto duplica custo de tratamento da água. São Paulo, 25 de julho de 2004. Cotidiano. 
ANEXOS 
Anexos I

Questionários aplicados em Manaus e Limeira para domicílios abastecidos por água de rede 


\section{UNIVERSIDADE DE SÃO PAULO \\ Faculdade de Filosofia, Letras e Ciências Humanas \\ Departamento de Geografia}

Questionário n. 03 sobre Saneamento Básico em Manaus (Aplicação para domicílios ligados à rede geral de água).

1. Nome do morador: Sile we ree hado de Silviz

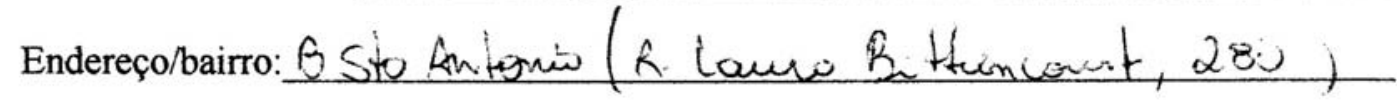

2. O Sr.(a) sabe informar o tempo do imóvel?

( ) imóvel recente (menos de 2 anos)

( ) 2 a 5 anos

( ) 5 anos e 1 mês a 10 anos

$(x)+$ de 10 anos

3. O Sr.(a) sabe dizer quanto tempo faz que o imóvel está conectado à rede? meses

28 anos

( ) Não sabe - ns

4. Como é a qualidade da água para o Sr.(a)?

$(x)$ boa ( ) regular ( ) ruim

5. Qual é o destino da água servida do imóvel?

$(X)$ rede de esgoto ( ) fossa séptica ( ) fossa comum ( ) vala negra ( ) a céu aberto

( ) encanamento próprio até curso d'água próximo,

( ) outros

6. Alguém residente no imóvel já sofreu com algum tipo de doença gastrintestinal aguda, seguidos de outros casos na família na mesma época? ( ) sim $(X)$ não

Se sim. Estas pessoas estiveram hospitalizadas por isto? ( ) sim ( ) não

Qual a freqüência de ocorrência deste problema entre os moradores desta residência?

( ) raramente, ( ) cerca de $1 \mathrm{vez}$ ao ano, ( ) cerca de 1 vez por semestre, ( ) cerca de 1 vez por mês, ( ) cerca de 1 vez por semana.

7. O Sr.(a) lembra de alguma campanha sobre economia de água? ( ) sim (X)não

Lembra quem divulgava esta campanha? ( ) empresa A.A., ( ) órgão público, ( )ns

8.Como é feita a cobrança pela água? ( $\times$ tarifa, ( ) taxa fixa, ( ) ns

9. Em relação aos valores cobrados pela água distribuída em rede o $\mathrm{Sr}$. os considera:

( ) baixos, ( ) justos, ( altos, ( ) abusivos

10. O Sr.(a) sabe informar se houve aumentos recentes dos valores cobrados pelos serviços de distribuição de água? $\operatorname{sim}$ ( ) não

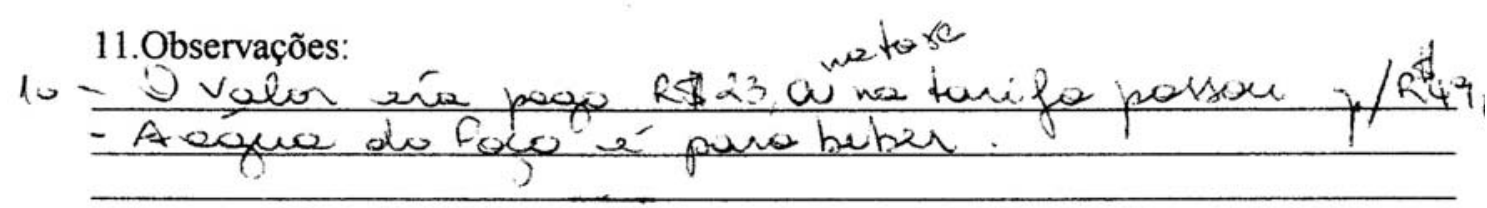




\section{UNIVERSIDADE DE SÃO PAULO \\ Faculdade de Filosofia, Letras e Ciências Humanas \\ Departamento de Geografia}

Questionário n. sobre Saneamento Básico em Limeira (Aplicação para domicilios ligados à rede geral de água).

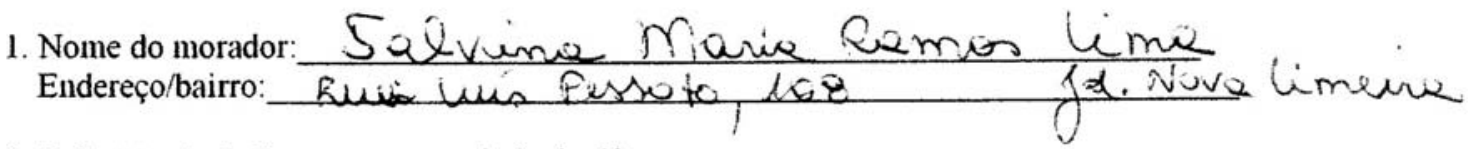

2. O Sr.(a) sabe informar o tempo do imóvel?

( ) imórel recente (menos de 2 anos)

( ) 2 a 5 anos

( .5 anos e 1 mès a 10 anos

( ) + de 10 anos

3. O Sr.(a) sabe dizer quanto tempo faz que o imórel está conectado à rede?

meses

( ) Não sabe - ns

4. Como é a qualidade da água para o Sr.(a)?

$(X)$ boa ( ) regular ( ) ruim

5. Qual é o destino da água servida do imórel?

$(X)$ rede de esgoto ( ) fossa séptica ( ) fossa comum ( ) vala negra ( ) a céu aberto

( ) encanamento próprio até curso d’água próximo.

( ) outros

6. Alguém residente no imóvel já sofreu com algum tipo de doença gastrintestinal aguda. seguidos de outros casos na familia na mesma época? ( ) sim $(X)$ nào

Se sim. Estas pessoas estiveram hospitalizadas por isto? ( ) sim ( ) não

Qual a frequiência de ocorrència deste problema entre os moradores desta residência?

( ) raramente. ( ) cerca de 1 vez ao ano. ( ) cerca de 1 vez por semestre. ( ) cerca de 1 vez por mès. ( ) cerca de 1 vez por semana.

7. O Sr.(a) lembra de alguma campanha sobre economia de água? ( $\varnothing$ ) sim ( )nào Lembra quem dirulgava esta campanha? ( ) empresa A.A.. $(\chi)$ órgão público. ( )ns

8. Como é feita a cobrança pela água? ('心 tarifa. ( ) taxa fixa. ( ) ns

9. Em relação aos valores cobrados pela água distribuida em rede o $\mathrm{Sr}$. os considera:

( ) baixos. ( ) justos. ( $\mathrm{X}$ ) altos. ( ) abusios

10. O Sr.(a) sabe informar se houve aumentos recentes dos valores cobrados pelos serviços de distribuição de água? $(\chi) \sin ($ ) não

11. Há interrupçòes constantes no abastecimento de água? ( ) sim $(X)$ nào

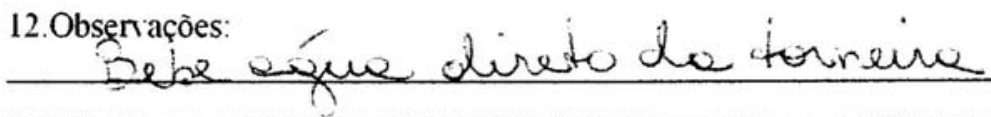




\section{Anexo II}

Questionários aplicados em Manaus para domicílios não ligados à rede de água 
UNIVERSIDADE DE SÃO PAULO

Faculdade de Filosefia, Letras e Ciêneias Humanas.

Questionário n. 115 sobre Saneamento Básico em Manaus (Aplicação para domicilios não ligados à rede geral de água).

1. Nome do morador: R. das Palmuiras, 424

Endereço/bairro: Marie Simone Silva de Oliveuro.

2. O Sr.(a) sabe informar o tempo do imóvel?

( ) imóvel recente (menos de 2 anos)

() 2 a 5 anos

(X) 5 anos e 1 mês a 10 anos

( ) + de 10 anos

3. Como é obtida a ăgua para o consumo doméstico?

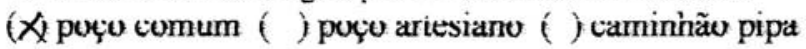

( ) outros

4. Como é a qualidade da água para o Sr:(a)?

X boa () regular () ruim

5. Qual é o destino da água servida do imóvel?

( ) rede de esgoto ( ) fossa séptica $($ ) fossa comum ( ) vala negra ( ) a céu aberto

$(X)$ encanamento próprio até curso d'água próximo

( ) outros

6. Algném residente no imóvel já sofreu com algum tịo de dọnça gastrintestinal aguda, seguidos de outros casos na familia na mesma época? $($ sim ( ) não

Se sim. Estas pessoas estiveram hospitalizadas por isto? $(X) \operatorname{sim}($ ) não

Qual a frequêencia de ocorrência deste problema entre os moradores desta residência?

$(X)$ raramente, ( ) cerca de 1 vez ao ano, ( ) cerca de 1 vez por semestre, ( ) cerca de 1 vez por mês, ( ) cerca de 1 vez por semana.

$7.0 \mathrm{Sr}$ (a) Iembra de alguma campanhạ sobre economiạ de água? ( ) sim (X)não Lembra quem divulgava esta campanha? ( ) empresa.A.A., ( ) órgão público, ( )ns

8 O Sr(a) está satisfeito com a sua forma de obtenção de ágụa para consụmo oụ preferia estar integrado à rede geral de água?

( ) está satisfeitó

(メ) preferia estar ligado à rede

() outros

9.
Observações: Baino muito poble o/ esagoto vizélal
Pare os cunsos d'équa 


\section{UNTVERSDADE DE SÃO PAULO \\ Faculdade de Filosofia, Letras e Ciências Humanas}

Departamentw de fengrafia
Questionário n. 30 sobre Saneamento Básico em Manaus (Aplicação para domicílios: não ligados à rede geral de água).

1. Nome do morador: Intzi le Alves de Silvairie Joms Endereço/bairro: Av Rin Nezio, 20 sto frapo

2. O Sr.(a) sabe informar o tempo do imóvel?

( ) imóvel recente (menos de 2 anos)

(x) 2 a 5 anos

( ) 5 anos e 1 mës a 10 anos

( ) + de 10 anos

3. Como e obtida a água para o consumo doméstico?

( ) poço comum ( ) puço ariesiano (') caminhão pipa

(x) outros Aque rinerai por encomemole

4. Como é a qualidade da água para o Sr.(a)?

$(X)$ boa () regular () ruim

5. Qual é o destino đa água servida do imóvel? igs ia hiouso

( ) rede de esgote ( ) fessa séptica ( $X$ ) fossa comum ( ) vala negra $(X)$ a céu aberto

( ) encanamento próprio até curso d'água próximo

( ) outros

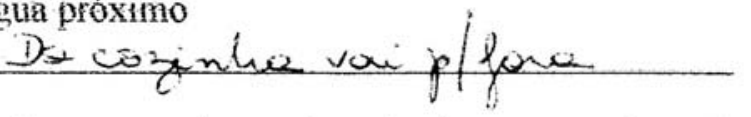

6. Alguém residente no imóvel já sofreu com algum tipo de doença gastrintestinạt aguda, seguidos de outros casos na familia na mesma época? $(\chi) \operatorname{sim}()$ não

Se $\operatorname{sim}$. Estas pessoas estiveram hospitalizadas por isto? $(X) \operatorname{sim}()$ ) não

Qual a frequência de ocorrência deste problema entre os moradores desta residência?

$(X)$ raramente, ( ) cerca de 1 vez ao ano, ( ) cerca de 1 vez por semestre, ( ) cerca de 1 vez por mês, ( ) cerca de 1 vez por semana.

7. O Sr (a) lembra de alguma campanha sobre economia de ágıa? ( ) sim (X)ẫo Lembra quem divulgava esta campanha? ( ) empresa A.A., ( ) órgão público, ( )ns

8. O $\mathrm{Sr}$ (a) está satisfeito $\mathrm{com}$ a sua forma de obtenção de água para consumo ou preferia estar integrado à rede geral de água?

() está satisfeito

( ) preferia estar ligado à rede

(x) outros jostari de her súfue de rede cunstente i

9.

Observações: 6- ERe Amibe pon comvermin cégus dì

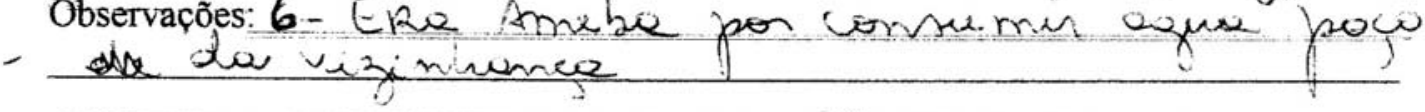

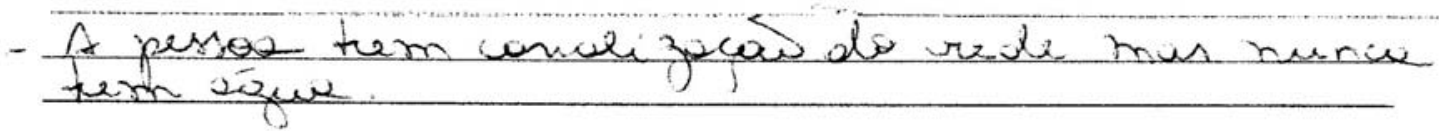




\section{Anexos III}

Laudos emitidos pelo Lacen de Manaus 


\section{LACEN}

Laboratório Central de Saúde Pública

AMMERODESTAODO

\begin{tabular}{l}
\hline O LACEN/AM, certifica que o resultado do Laudo N $^{\circ} \mathbf{3 6 2 3 / 2 0 0 4}$, foi o seguinte: \\
\hline PROCEDÊNCIA: RESIDÊNCIA (RUA LAURO BITTENCOURT, 280 - BAIRRO SANTO ANTONIO - \\
MANAUS -AM) \\
PRODUTO: ÁGUA DA ÁGUAS DO AMAZONAS \\
ORIGEM: TORNEIRA DA RUA \\
INTERESSADO: CRISTIANE FERNANDES DE OLIVEIRA (SÃO PAULO/SP) \\
RESP. PELA COLETA: CRISTIANE FERNANDES DE OLIVEIRA (SÃO PAULO/SP) \\
DATA DA COLETA: 05/07/2004 \\
INÍCIO DA ANÁLISE: 05/07/2004 \\
No DO TERMO DE APREENSÃO E/OU COLETA: - \\
\hline
\end{tabular}

\begin{tabular}{l}
\hline 1- METODOLOGIA: \\
$\begin{array}{l}\text { Foram adotadas as normas técnicas do "Standard Methods for the Examination of Water and Wastewater" } \\
\text { editado pela APHA para procedimento das análises. }\end{array}$ \\
\hline
\end{tabular}

\begin{tabular}{|c|c|c|}
\hline $\begin{array}{l}\text { 2-DETERMINAÇÃO } \\
\text { FISÍCO-QUÍMICA: }\end{array}$ & $\begin{array}{c}\text { Portaria } \mathrm{N}^{\circ} 1.469 \text {, } \\
\text { de } 29 \text { de Dezembro de } 2000\end{array}$ & RESULTADOS \\
\hline Aspecto & - & Limpido \\
\hline Odor & Não Objetável & Nào Objetável \\
\hline Depósito & - & Ausente \\
\hline Cor & $15 \mathrm{Uh}$ & 17 Uh \\
\hline $\mathrm{PH}$ & 6,0 a $9,5 \mathrm{VPM}$ & 6,05 \\
\hline Turbidez & 5 NTU & $0,50 \mathrm{NTU}$ \\
\hline Alcalinidade de Bicarbonatos & - & 3,3 \\
\hline Dureza total & $500 \mathrm{mg} /$ litro & $21 \mathrm{mg} /$ litro \\
\hline Gás Carbônico & p.p.m. & 6,0 p.p.m. \\
\hline Cloro total & - & - \\
\hline Cloro residual livre & 0,2 a $2,0 \mathrm{mg} /$ litro & 0,1 mg/litro \\
\hline Amônia & $1,5 \mathrm{mg} /$ litro & $0,229 \mathrm{mg} /$ litro \\
\hline Cloreto & $250 \mathrm{mg} /$ litro & $5,9 \mathrm{mg} /$ litro \\
\hline Ferro & $0,3 \mathrm{mg} /$ litro & $0,051 \mathrm{mg} /$ litro \\
\hline Sulfato & $250 \mathrm{mg} /$ litro & $10,58 \mathrm{mg} /$ litro \\
\hline Sulfeto & $0,050 \mathrm{mg} /$ litro & - \\
\hline Sólidos dissolvidos totais & $1000 \mathrm{mg} /$ litro & - \\
\hline Temperatura & - & - \\
\hline
\end{tabular}

* ND - NÃO DETECTADO.

\begin{tabular}{|l|}
\hline 3- DETERMINAÇÃO \\
MICROSCOPIA: \\
\hline - AUSÊNCIA de parasitos. \\
\hline
\end{tabular}

\section{4- CONCLUSÃO:}

A amostra de água analisada, encontra-se em DESACORDO com a Portaria n ${ }^{\circ} 1.469$ de 29/12/2000.

\section{5- OBSERVAÇŌES:}

- VEDADA a utilização deste laudo como forma de propaganda.

OS RESULTADOS DESTA ANÁLISE TEM VALOR RESTRITO E SE APLICAM A AMOSTRA ANALISADA.

* Cor acima valor máximo permitido.

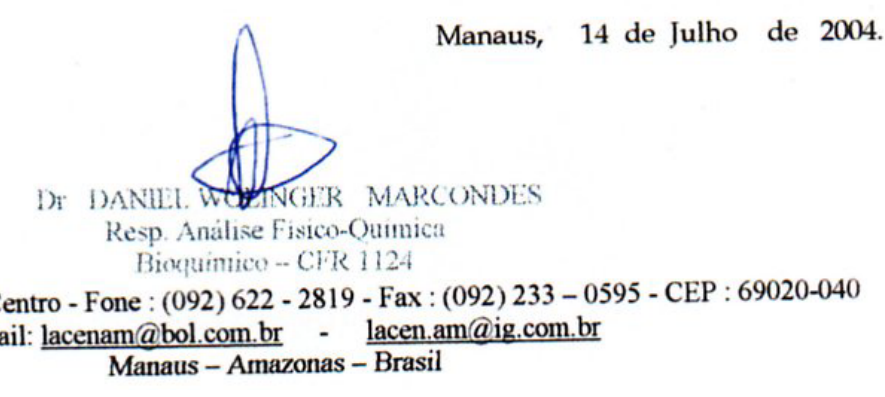




\section{LACEN}

Laboratorio Central de Saúde Pública

AMAZONOAS

O LACEN/AM, certifica que o resultado do Laudo $N^{\circ} 3714 / 2004$, foi o seguinte:

PROCEDENCIA: RESIDENCIA (RUA NOSSA SENHORA DE FÁTIMA N ${ }^{\prime} 12$ - BAIRRO SANTA EIELVINA

- MANAUS-AM)

PRODUTO: AGUA DA AGUAS DO AMAZONAS

ORIGEM: TORNEIRA DE ENTRADA DA REDE DE AGUA

INTERESSADO: CRISTIANE FERNANDES DE OLIVEIRA (SÃO PAULO/SP)

RESP. PELA COLETA: CRISTIANE FERNANDES DE OLIVEIRA (SÃO PAULO/SP)

DATA DA.COLET A: $12 / 07 / 2004 \quad$ ENTPADA NO SEIOE: $12 / 07 / 2004$

INICIO DA ANALISE: $12 / 07 / 2004$ TERMTNO DA ANALISE: 30/07/2004

N"DO TERMO DE APREENSAO E/OU COLETA: -

\section{1- METODOLOGIA:}

Foram adotadas as normas tórnicas do "Standard Methods for the Examination of Water and Wastewater" editado pela APHA para procedinento das análises.

\begin{tabular}{|l|c|c|}
\hline $\begin{array}{l}\text { 2-DETERMINACCAO } \\
\text { MICROBIOLOGICA: }\end{array}$ & $\begin{array}{c}\text { Portaria N } 1.469, \\
\text { de } 29 \text { de Dezembro de } 2000\end{array}$ & RESULTADOS \\
\hline Coliformes Totais & - & PRESENÇA em 100ml \\
\hline Coliformes Termotolerantes a $45^{\circ} \mathrm{C}$ & Ausencia em $100 \mathrm{ml}$ & PRESENÇ em $100 \mathrm{ml}$ \\
\hline
\end{tabular}

\begin{tabular}{|c|c|c|}
\hline $\begin{array}{l}\text { 3-DETERMINAÇAO } \\
\text { FISICO-QUIMICA: }\end{array}$ & $\begin{array}{c}\text { Portaria N } 1.469 \\
\text { de } 29 \text { de Dezembro de } 2000\end{array}$ & RESULTADOS \\
\hline Aspecto & 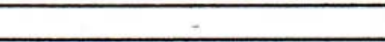 & Limpido \\
\hline Odor & Nà Ohjetável & Nao Objetável \\
\hline Deposito & - & Ausente \\
\hline Cor & $15 \mathrm{CT}_{2}$ & $<3 \mathrm{Uh}$ \\
\hline $\mathrm{PH}$ & 6,0 a $9,5 \mathrm{VPM}$ & 5,20 \\
\hline Turbictes & $5 \mathrm{NTU}$ & 0,16 NTU \\
\hline Alcalinidado de Buarbonatos & - & 11,61 \\
\hline Durezatotal & $510 \mathrm{mg} /$ litro & $2,61 \mathrm{mg}$ /litro \\
\hline Gảs Carbónico & R.p.m. & $\begin{array}{ll}\text { ND }^{n} & \text { p.p.m. } \\
\end{array}$ \\
\hline Cloro total & - & - \\
\hline Cloro residual livre? & $0,2 \mathrm{a} 2,0 \mathrm{mg} /$ hitro & $\mathrm{ND}^{*}$ ing/litro \\
\hline Amónia & $1,5 \mathrm{mg} /$ litro & $<0,005 \mathrm{mg}$ /litro \\
\hline Cloreto & $250 \mathrm{mg} / \mathrm{htho}$ & $\mathrm{ND}^{+} \mathrm{mg} /$ litro \\
\hline Fetro & $0,3 \mathrm{mg} /$ litro & $0,008 \mathrm{mg} / \mathrm{litro}$ \\
\hline Sulfato & $250 \mathrm{mg} /$ litro & $0.98 \mathrm{mg} / \mathrm{ltro}$ \\
\hline Sulfeto & $0,050 \mathrm{mg} /$ litro & - \\
\hline Sólidos dissofvidos torais & $1000 \mathrm{~m} g /$ litro & - \\
\hline Temperalura & - & - \\
\hline
\end{tabular}

* ND - NÄO DETECTADO.

\begin{tabular}{l|}
\hline 4- DETFRMINACAO \\
MICROSCOPL: \\
\hline - AUSEENCIA de parasitos. \\
\hline
\end{tabular}

5- CONCLUSÄO:

A amostra de água analisada, encionira-se em DESACORDO com a Porlaria $n^{\circ} 1.469$ de $29 / 12 / 2000$.

6- OBSERVACÖES:

- VEDADA a utilizaçăo deste laudo como forma de propayanda.

OS RESULTADOS DESTA AN ALISE TEM Y ALOR RESTRITO E SE APLICAM A AMOSTRA ANALISADA.

- Aconselhamos que seja providencjado uma higienizaçào com desincrustante e doraçào do poço e nos

respectivos reservatórios de água (cisterna efou caixa d’água).

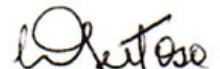

Dru LOUYAMURA FEITOSA DE ARAUUO

Resp. Análise Microbiológica

Himenumico - CRF 325

Rua Emilio Moreira, 528 Centro - Fone : $(092) 622$ - 2819 - Fax : (092) 233 - 0595 - C1PP : 690) 20-(140)

E-mail: lacenamabol.com br - lacen amaigcombr

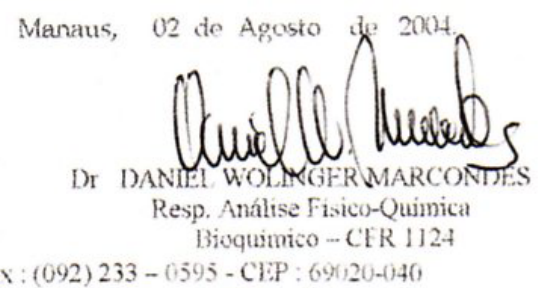




\section{LACEN}

Laboratório Central de Saúde Pública

AMAZOONAS

O LACEN/AM, certifica que o restutado do Laudo $N^{\circ} 2477 / 2004$, foi o seguinte:

zianalise

PFOCEDÉNCIA: HOSPITAL ADRIANO JORGE (AV CARVALHO LEAL, 1778 - CACHOEIRINHA -

MANAUS -AM)

PRODUTO: ÁGUA DE POÇO

ORIGEN: DIRETO DO POÇO

INTERESSADO: SISAGUA

RESPP. PELA COLETA: ROCILENE SILVA

DATA DA COLETA: $26 / 04 / 2004$

INICIO DA ANALLISE: 26/04/2004

ENTRADA NO SETOR: 26/04/2004

N" DO TERMO DE APREENSÄO E/OU COLETA: -

TEERMINO DA ANÁLISE: 09/06/2004

\section{1- METODOLOGLA:}

Foram adotadas as normas técnicas do "Standard Methods for the Examination of Water and Wastewater" editadu pola APHA para procedimento des análises.

\begin{tabular}{|c|c|c|}
\hline $\begin{array}{l}\text { 2-DETERMINACCÄO } \\
\text { MICROBIOLÓGICA: }\end{array}$ & $\begin{array}{c}\text { Portaria } N^{\circ} 1.469, \\
\text { de } 29 \text { de Dezembro de } 2000\end{array}$ & RESULTADOS \\
\hline Coliformes Totais & 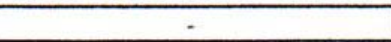 & PRESENÇA em $100 \mathrm{ml}$ \\
\hline Coliformes Termotolerantas a $+5^{\circ} \mathrm{C}$ & Ausência emr 100ml & AUSENCIA em $100 \mathrm{ml}$ \\
\hline
\end{tabular}

\begin{tabular}{|c|c|c|}
\hline $\begin{array}{l}\text { 3-DETERMINAÇÃO } \\
\text { FISICO-QUIMICA: }\end{array}$ & $\begin{array}{c}\text { Portaria N } 1.469 \\
\text { de } 29 \text { de Dezembro de } 2000\end{array}$ & RESULTADOS \\
\hline Aspecto & - & Límpido \\
\hline Odor & Náo Objetável & Nào Objetável \\
\hline Depósilo & - & Ausente \\
\hline Cor & 15 Uh & 3 Uh \\
\hline $\mathrm{PH}$ & 6,0 a $9,5 \mathrm{VPM}$ & 5,29 \\
\hline Turbidez & 5 NIU & $1,01 \mathrm{NTU}$ \\
\hline Akalinidade de Bicarbonatos & - & 8,73 \\
\hline Dureza lotal & $500 \mathrm{mg} /$ litro & $17,30 \mathrm{mg} / \mathrm{litro}$ \\
\hline Gás Carhonico & F.F.m. & 85 p.p.m. \\
\hline Cloro total & - & - \\
\hline Cloro residual livre & 0,2 a $2,0 \mathrm{mg} /$ litro & $0,05 \mathrm{mg} /$ litro \\
\hline Amônia & $1,5 \mathrm{mg} / 1 \mathrm{litro}$ & $0,074 \mathrm{ng} /$ /itro \\
\hline Clorets & $250 \mathrm{mg} / \mathrm{hitro}$ & $5,96 \mathrm{mg} /$ litro \\
\hline Forro & $0,3 \mathrm{mg} /$ litro & $\mathrm{ND}^{*}$ \\
\hline Sulfato & $250 \mathrm{mg} /$ litro & $\mathrm{ND}^{*}$ \\
\hline Sulfoto Total & - & $0,655 \mathrm{mg}$ /litro \\
\hline Sulfeto de Hidrogénio & $0,050 \mathrm{mg} /$ Jitro & $0,641 \mathrm{mg} /$ litro \\
\hline Sólidos dissolvidos totais & $1000 \mathrm{mg} /$ litro & $51 \mathrm{ing} /$ litro \\
\hline Temporatura & - & - \\
\hline
\end{tabular}

*ND - NÃO-DETECTADO.

3- DETERMINAÇÃO

MICROSCOPIA:

- ALSEENClA de porasitos.

\section{4- CONCLUSAO:}

A amostra de água analisada, encontra-se em DESACORDO com a Portaria $n^{\circ} 1.469$ de $29 / 12 / 2000$

\section{5- OBSERVACOOES:}

- VEDADA a utilizacan deste laudo cono forma de propagranda.

- OS RESUlJADOS DESTA ANÁlISE TEM VALOR RESTRITO E SE APLICAM A AMOSTRA ANALISADA.

- Aconselhamos que seja providenciado uma cloraçáo no respectivo poço artesiano, por apresentar bactérias do grupo coliforme total.

- pH muilo abaixo do valor ninimo recomendado;

- CIoro Residual Livere abaixo do valor permitido. Recomendo a ctoraçáo da água;

-Sulfeto de Hidrogenio acima do valor máxino permitido. 
O LACEN/AM, certifica que o resultado do Laudo $N^{\circ} 3621 / 2004$, foi o seguinte: PROCEDÊNCIA: RESIDÊNCIA (AV AYRÃO, 319 - BAIRRO PRESIDENTE VARGAS - MANAUS -AM) PRODUTO: ÁGUA DA ÁGUAS DO AMAZONAS

ORIGEM: TORNEIRA DA RUA

INTERESSADO: CRISTIANE FERNANDES DE OLIVEIRA (SÃO PAULO/SP)

RESP. PELA COLETA: CRISTIANE FERNANDES DE OLIVEIRA (SÃO PAULO/SP)

DATA DA COLETA: 05/07/2004

INÍCIO DA ANÁLISE: 05/07/2004

ENTRADA NO SETOR: 05/07/2004

No DO TERMO DE APREENSÃO E/OU COLETA: -

TÉRMINO DA ANÁLISE: 13/07/2004

\section{1-METODOLOGIA:}

Foram adotadas as normas técnicas do "Standard Methods for the Examination of Water and Wastewater" editado pela APHA para procedimento das análises.

\begin{tabular}{|c|c|c|}
\hline $\begin{array}{l}\text { 2-DETERMINAÇÃO } \\
\text { FISICO-QUIMIMICA: }\end{array}$ & $\begin{array}{c}\text { Portaria } N^{\circ} 1.469, \\
\text { de } 29 \text { de Dezembro de } 2000\end{array}$ & RESULTADOS \\
\hline Aspecto & - & Límpido \\
\hline Odor & Não Objetável & Não Objetável \\
\hline Depósito & - & Ausente \\
\hline Cor & $15 \mathrm{Uh}$ & 13 Uh \\
\hline $\mathrm{PH}$ & 6,0 a 9,5 VPM & 6,11 \\
\hline Turbidez & 5 NTU & 0,6 NTU \\
\hline Alcalinidade de Bicarbonatos & - & 3,8 \\
\hline Dureza total & $500 \mathrm{mg} /$ litro & $22 \mathrm{mg} /$ litro \\
\hline Gás Carbônico & p.p.m. & 6,0 p.p.m. \\
\hline Cloro total & - & - \\
\hline Cloro residual livre & 0,2 a $2,0 \mathrm{mg} /$ litro & $0,3 \mathrm{mg} / \mathrm{litro}$ \\
\hline Amônia & $1,5 \mathrm{mg} /$ litro & $<0,005 \mathrm{mg} /$ litro \\
\hline Cloreto & $250 \mathrm{mg} /$ litro & $5,9 \mathrm{mg} /$ litro \\
\hline Ferro & $0,3 \mathrm{mg} /$ litro & $0,051 \mathrm{mg} /$ litro \\
\hline Sulfato & $250 \mathrm{mg} /$ litro & $10,58 \mathrm{mg} /$ litro \\
\hline Sulfeto & $0,050 \mathrm{mg} /$ litro & - \\
\hline Sólidos dissolvidos totais & $1000 \mathrm{mg} /$ litro & - \\
\hline Temperatura & - & - \\
\hline
\end{tabular}

*ND - NÃO DETECTADO.

\section{3- DETERMINAÇÃO}

MICROSCOPIA:

- AUSÉNCIA de parasitos.

\section{4- CONCLUSÃO:}

A amostra de água analisada, encontra-se em ACORDO com a Portaria ${ }^{\circ} 1.469$ de 29/12/2000.

\section{5- OBSERVAÇOES:}

- VEDADA a utilização deste laudo como forma de propaganda.

OS RESULTADOS DESTA ANÁLISE TEM VALOR RESTRITO E SE APLICAM A AMOSTRA ANALISADA.

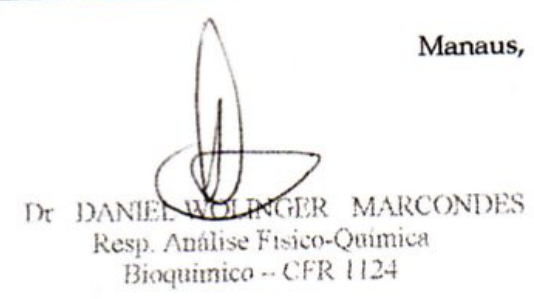

Rua Emilio Moreira, 528 Centro - Fone : (092) 622 - 2819 - Fax : (092) 233 - 0595 - CEP : 69020-040

E-mail: lacenamabol.com.br - lacen.am@ig.com.br

Manaus - Amazonas - Brasil 


\section{LACEN}

Laboratório Central de Saúde Pública

GOVEUTO DO EBTADODO

AMAZONASS

O LACEN/AM, certifica que o resultado do Laudo $N^{\circ}$ 914/2004, foi o seguinte:

i.inalise. PROCEDENCIA:CAIC - DR. EDSON MELO - ALAMEDA FERREIRA, Nº 7995 - ZUMBI II - MANAUS/AM) PRODUTO: ÁGUA DE POÇO

ORIGEM: DIRETO DO POÇO - AMOSTRA N 02

INTERESSADO: SISAGUA/SUSAM

RESP. PELA COLETA: ROCILENE SILVA

DATA DA COLETA: 11/02/2004

ENTRADA NO SETOR: 11/02/2004

INICIO DA ANÁLISE: 10/02/2004

TÉRMINO DA ANÁLISE: 17/02/2004

NN DO TERMO DE APREENSÃO E/OU COLETA: -

\section{1- METODOLOGIA:}

Foram adotadas as normas técnicas do "Standard Methods for the Examination of Water and Wastewater" editado pela APHA para procedimento das análises.

\begin{tabular}{|l|c|c|}
\hline $\begin{array}{l}\text { 2-DETERMINAÇÃO } \\
\text { MICROBIOLÓGICA: }\end{array}$ & $\begin{array}{c}\text { Portaria } \mathrm{N}^{\circ} 1.469, \\
\text { de 29 de Dezembro de 2000 }\end{array}$ & RESULTADOS \\
\hline Coliformes Totais & - & AUSÊNCIA em 100ml \\
\hline Coliformes Termotolerantes a $45^{\circ} \mathrm{C}$ & Ausência em $100 \mathrm{ml}$ & AUSÊNCIA em 100ml \\
\hline
\end{tabular}

\begin{tabular}{|c|c|c|}
\hline $\begin{array}{l}\text { 3-DETERMINAÇĀO } \\
\text { FISÍCO-QỨMICA: }\end{array}$ & $\begin{array}{c}\text { Portaria } N^{\circ} 1.469 \\
\text { de } 29 \text { de Dezembro de } 2000\end{array}$ & RESULTADOS \\
\hline Aspecto & - & Límpido \\
\hline Odor & Não Objetável & Ausente \\
\hline Depósito & - & Ausente \\
\hline Cor & $15 \mathrm{Uh}$ & $<3 \mathrm{Uh}$ \\
\hline $\mathrm{PH}$ & 6,0 a $9,5 \mathrm{VPM}$ & 4,74 \\
\hline Turbidez & $5 \mathrm{NTU}$ & 0,0 NTU \\
\hline Alcalinidade de Bicarbonatos & - & 1,27 \\
\hline Dureza total & $500 \mathrm{mg} /$ litro & $1,01 \mathrm{mg} / \mathrm{litro}$ \\
\hline Gás Carbônico & p.p.m. & - \\
\hline Cloro total & - & - \\
\hline Cloro residual livre & 0,2 a $2,0 \mathrm{mg} /$ litro & 0,01 mg/litro \\
\hline Amônia & $1,5 \mathrm{mg} /$ litro & $0,009 \mathrm{mg} /$ litro \\
\hline Cloreto & $250 \mathrm{mg} / \mathrm{litro}$ & $\mathrm{ND}^{*} \mathrm{mg} / \mathrm{litro}$ \\
\hline Ferro & $0,3 \mathrm{mg} /$ litro & $0,013 \mathrm{mg} /$ litro \\
\hline Sulfato & $250 \mathrm{mg} /$ litro & ND*mg/litro \\
\hline Sulfeto & $0,050 \mathrm{mg} /$ litro & $0,396 \mathrm{mg} /$ litro \\
\hline Solidos dissolvidos totais & $1000 \mathrm{mg} /$ litro & $46 \mathrm{mg} /$ litro \\
\hline Temperatura & - & - \\
\hline
\end{tabular}

\section{* ND - NÃO DETECTADO.}

\section{3- DETERMINAÇÃO}

MICROSCOPIA:

- AUSENCIA de parasitos.

\section{4- CONCLUSÃO:}

A amostra de água analisada, encontra-se em DESACORDO com a Portaria $n^{\circ} 1.469$ de 29/12/2000.

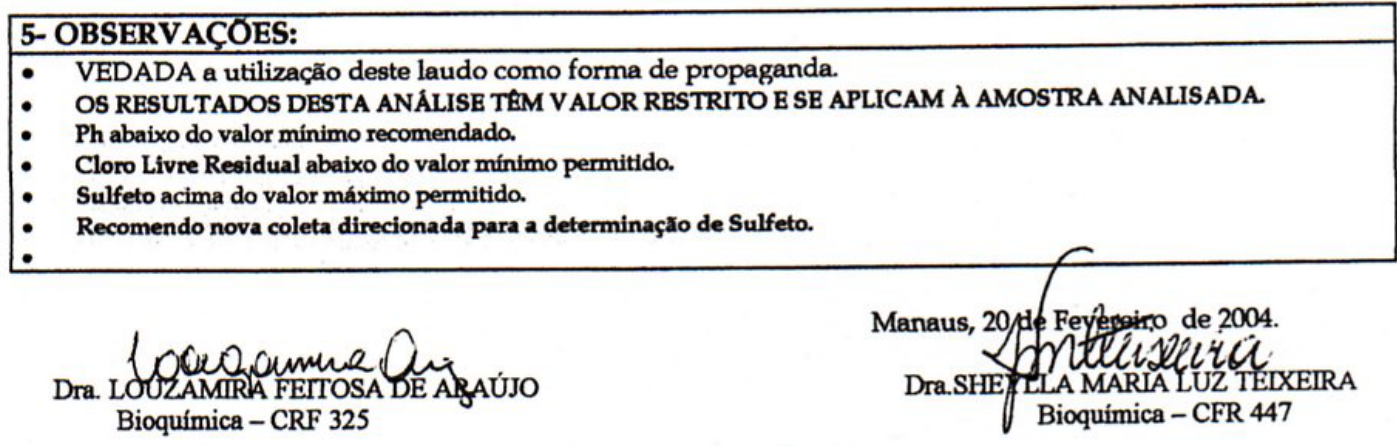




\section{Anexo IV}

Laudo emitido pelo Instituto Adolfo Lutz sobre amostra de água do Programa “Pró-Água” de Limeira 
Secretaria de Estado da Saúde

Coordenação dos Institutos de Pesquisa

Instituto Adolfo Lutz

Laboratório Regional de Campinas

Data: $25 / 10 / 2004$

Hora: 11:36:21

Laudo de Análise $\quad 2435.00 / 2004$

Via: 1

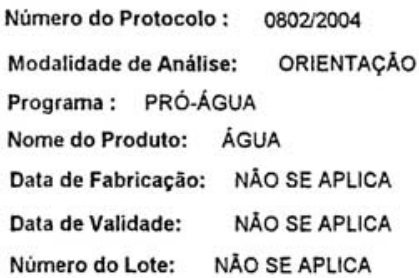

Número do Protocolo : $\quad$ 0802/2004

Modalidade de Análise: ORIENTAÇÃO

Programa: PRÓ-ÁGUA

Nome do Produto: ÁGUA

Data de Fabricação: NÃO SE APLICA

Data de Validade: NÃO SE APLICA

Número do Lote: NÃO SE APLICA

Registro: NÃO SE APLICA

Governativo: PREFEITURA MUNICIPAL DE LIMEIRA - SEC. MUN. DA SAÚDE-ADVS

Pais: BRASIL

Local de Coleta: DROGARIA NOVA LIMEIRA - R. LUIZ PESSOTO - JD. NOVA LIMEIRA

Requerente: PREFEITURA MUNICIPAL DE LIMEIRA - SEC. MUN. DA SAÚDE-ADVS

Pessoa de Contato: REGIANE APARECIDA JACON

Documento: OF. ADVS N $174 / 2004$

Data de Entrada: 20/10/2004

Descrição da Amostra: $\quad$ AMOSTRA 9 - ABASTECIMENTO PÚBLICO.

DADOS FORNECIDOS PEE COIETOR. CANALIZADA, FLUORETADA TRATADA, MANANCIAL

DADOS FORNECIDOS PELO COLETOR: CANALIZADA, FLUORETADA TRATADA, MANANCIAL LIVRE: $1,5 \mathrm{mg} / \mathrm{L}$ E $\mathrm{pH}: 7,8$. 
Secretaria de Estado da Saúde

Coordenação dos Institutos de Pesquisa

Instituto Adolfo Lutz

Laboratório Regional de Campinas

Data: $25 / 10 / 2004$

Hora: 11:36:21

Laudo de Análise 2435.00/2004

Via : 1

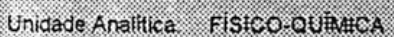

Nome do Ensaio: Cor aparente

Referència: PORTARIA N ${ }^{\circ} 518$, DE 25 DE MARÇO DE 2004, MS

Valor de Referència: VALOR MÁXIMO PERMITIDO: $15 \mu \mathrm{H}$

Resultado: 2 HAZEN

Conclusão: SATISFATÓRIO

Nome do Ensaio: Turbidez

Referência: PORTARIA N 518, DE 25 DE MARÇO DE 2004, MS

Valor de Referência: VALOR MÁXIMO PERMITIDO: 5 UT

Resultado: 0,37 FTU

Conclusão: SATISFATÓRIO

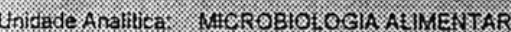

Nome do Ensaio: Coliformes totais

Referência: PORTARIA Nº 518, DE 25 DE MARÇO DE 2004, MS

Valor de Referência: AUSÊNCIA EM $100 \mathrm{~mL}$

Resultado: AUSÊNCIA EM $100 \mathrm{~mL}$

Conclusão: SATISFATÓRIO

Nome do Ensaio: E.coli ou Coliformes Termotoierantes

Referència: PORTARIA N 518, DE 25 DE MARÇO DE 2004, MS

Valor de Referência: AUSÊNCIA EM $100 \mathrm{~mL}$

Resultado: AUSÊNCIA EM $100 \mathrm{~mL}$.

Conclusão: SATISFATÓRIO 
Secretaria de Estado da Saúde

Coordenação dos Institutos de Pesquisa

Instituto Adolfo Lutz

Laboratório Regional de Campinas

Data: $25 / 10 / 2004$

Hora: 11:36:21

Laudo de Análise 2435.00/2004

Via : 1

Conclusão: SATISFATÓRIA

Complemento da Conclusão:

ÁGUA DE ACORDO COM A LEGISLAÇÃO EM VIGOR (PORTARIA 518 DE 25.03.2004 DO M.S.) QUANTO AOS ENSAIOS REALIZADOS.

Em, 25/10/2004

$\frac{\text { mavie Hdini }}{\text { it Beatriz Pisani }}$

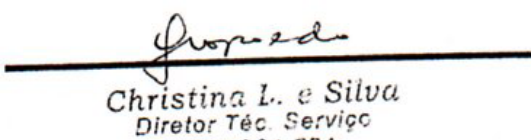

Diretor Téc Servigco

Re 5.024 .794 